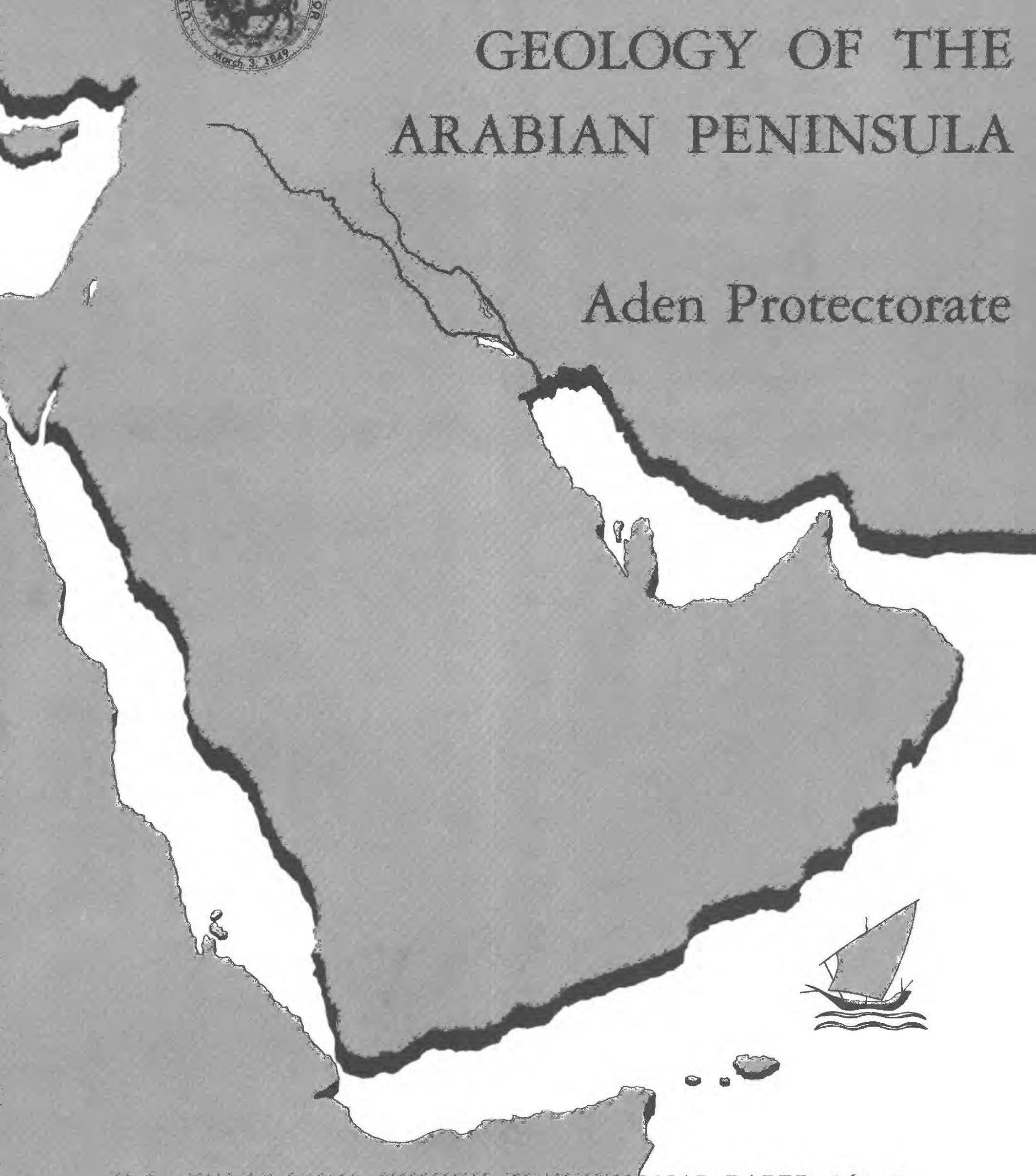

U.S. GEOLOGICAL SURVEY PROFESSIONAL PAPER 560-C 


\section{Geology of the Arabian Peninsula}

Aden Protectorate

By J. E. G. W. GREENWOOD and D. BLEACKLEY

U.S. GEOLOGICAL SURVEY PROFESSIONAL PAPER 560-C

$A$ survey of the geology of the Western Aden Confederation as shown on USGS Miscellaneous Geologic Investigations Map I-270 A, "Geologic Map of the Arabian Peninsula," I963

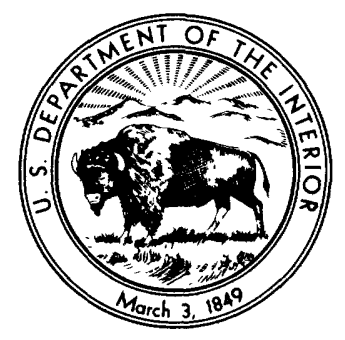




\section{DEPARTMENT OF THE INTERIOR \\ DONALD PAUL HODEL, Secretary}

\section{U.S. GEOLOGICAL SURVEY}

Dallas L. Peck, Director

First printing 1967

Second printing 1985

For sale by the Distribution Branch, U.S. Geological Survey 604 South Pickett Street, Alexandria, VA 22304 


\section{FOREWORD}

This volume, "The Geology of the Arabian Peninsula," is a logical consequence of the geographic and geologic mapping project of the Arabian Peninsula, a cooperative venture between the Kingdom of Saudi Arabia and the Government of the United States. The ArabianAmerican Oil Co. and the U.S. Geological Survey did the fieldwork within the Kingdom of Saudi Arabia, and, with the approval of the governments of neighboring countries, a number of other oil companies contributed additional mapping to complete the coverage of the whole of the Arabian Peninsula. So far as we are aware, this is a unique experiment in geological cooperation among several governments, petroleum companies, and individuals.

The plan for a cooperative mapping project was originally conceived in July 1953 by the late William E. Wrather, then Director of the U.S. Geological Survey, the late James Terry Duce, then Vice President of Aramco, and the late E. L. deGolyer. George Wadsworth, then U.S. Ambassador to Saudi Arabia, and Sheikh Abdullah Sulaiman, then Minister of Finance of the Government of Saudi Arabia, lent their support to the plan. In November of the following year, 1954, Director Wrather approved the U.S. Geological Survey's participation and designated G. F. Brown responsible for the western Arabian shield region in which he had previously worked under U.S. foreign-aid programs. In January 1955 F. A. Davies, Chairman, Board of Directors, Arabian-American Oil Co., approved Aramco's participation and appointed the late R. A. Bramkamp, chief geologist, responsible for compilation of the area within the Kingdom where the sediments crop out. This responsibility fell to L. F. Ramirez following the death of R. A. Bramkamp in September 1958.

R. A. Bramkamp and G. F. Brown met in New York in February 1955 and planned the program, including scales of maps, areas of responsibility, types of terrain representation, and bilingual names. Thus there was established a cooperative agreement between the Kingdom of Saudi Arabia, the U.S. Department of State, and the Arabian-American Oil Co. to make available the basic areal geology as mapped by Aramco and the U.S. Geological Survey.

The agreement specified publication of a series of 21 maps on a scale of $1: 500,000$, each map covering an area $3^{\circ}$ of longitude and $4^{\circ}$ of latitude. Separate geologic and geographic versions were to be printed for each of the quadrangles; both versions were to be bilingual-in Arabic and English. A peninsular geologic map on a scale of $1: 2,000,000$ was to conclude the project.

High-altitude photography, on a scale of 1:60,000, of the Kingdom of Saudi Arabia was initiated during 1949 by the Aero Service Corp. and completed in 1959. Both third-order vertical and horizontal control and shoran were utilized in compiling the photography. This controlled photography resulted in highly accurate geographic maps at the publication scale which then served as a base for the geologic overlay. The topography of the sedimentary areas was depicted by hachuring and that of the shield region by shaded relief utilizing the airbrush technique.

The first geographic quadrangle was published in July 1956 and the last in September 1962. While preparation of the geographic sheets was in progress, a need arose for early publication of a $1: 2,000,000$-scale peninsular geographic map. Consequently, a preliminary edition was compiled and published in both English and Arabic in 1958. The second edition, containing additional photography and considerable new topographic and cultural data, was published in 1963. The first of the geologic map series was published in July 1956 and the final sheet in early 1964. The cooperative map project was completed in October 1963 with the publication of the 1:2,000,000-scale "Geologic Map of the Arabian Peninsula" (Miscellaneous Geologic Investigations Map I-270 A). 
As work on the quadrangles progressed, geologists, companies, and governments working in areas adjacent to the Kingdom of Saudi Arabia were consulted by Aramco and invited to participate in the mapping project. The number of cooperating participants was expanded to 11 , which included the operating oil companies in the peninsula and which are identified elsewhere in this text; the Overseas Geological Surveys, London; the Government of Jordan; F. Geukens, who had worked in Yemen; and Z. R. Beydoun, who had studied the Eastern Aden Protectorate. With the close cooperation of the authors, the new data were added to data already plotted on the base map of the Arabian Peninsula.

As the geological coverage of the peninsular map grew, the need for a text to accompany the map became apparent to both the U.S. Geological Survey and the Aramco geologists. Exploratory conversations were begun by Aramco with companies working in the other countries of the Arabian Peninsula for their participation in the preparation of a monograph on the geology of the Arabian Peninsula. Each author prepared a description of the geology of the area for which he was responsible, as shown in the sources of geologic compilation diagram on the peninsular map. The U.S. Geological Survey undertook the publishing of the volume as a professional paper, and the Government of Saudi Arabia was to finance its printing. It was early agreed that there would be no effort to confine the contributions to a standard format and that no attempt would be made to work out an overall correlation chart other than shown on the "Geologic Map of the Arabian Peninsula." Thus, the individual style of authors of several nationalities is preserved.

Cooperation and relations have been of the highest order in all phases of the work. The project would not have been possible without the full support of the U.S. Department of State, the Kingdom of Saudi Arabia, and all contributors. In fact, the funds which made publication of this volume possible were contributed by the Saudi Arabian Government.

The data provided by the maps and in the professional paper provide information for an orderly scientific and economic development of a subcontinent.

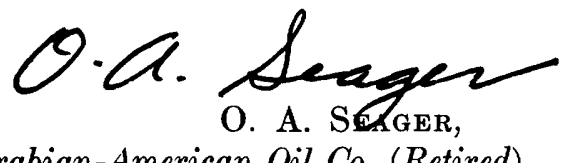
Arabian-American Oil Co. (Retired).

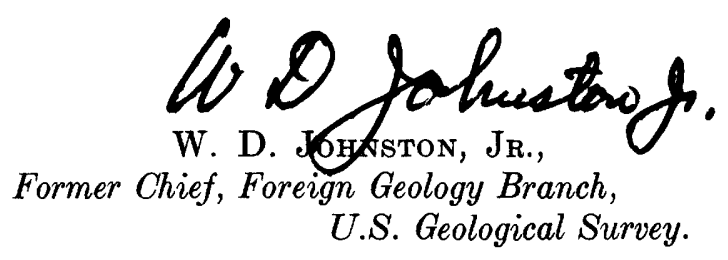




\section{CONTENTS}

Foreword

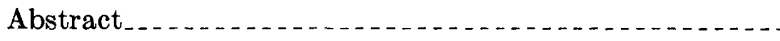

Introduction

Purpose and scope.........

Previous work

Present investigations . . . . . . . . .

Photogeological survey ..................

Field survey . . . . . . . . .

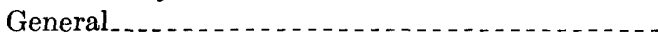

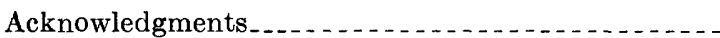

Geography

Area, location, and population......................

Transportation and communications . . . . . . . . .

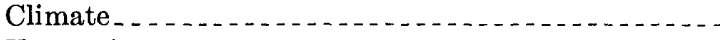

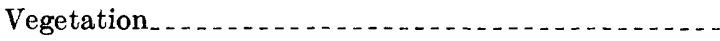

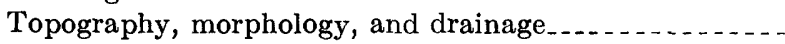

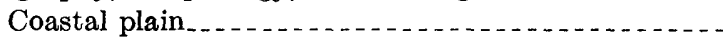

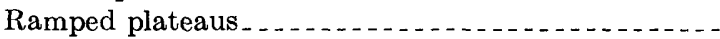

Sand desert and gravel plain

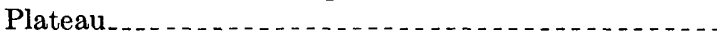

Geology

Basement-rock units and petrography

Older gneiss.....................

Aden Metamorphic Group. .............

Pelitic rocks_._._.

Psammitic rocks . . . . . .

Metacalcareous rocks_._._._._._._.

Metamorphosed mafic igneous rocks.......

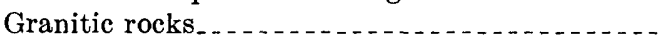

Syntectonic granite.

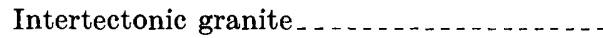

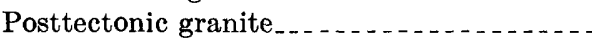

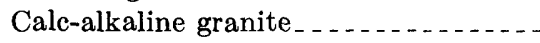

Alkaline granite.

Mafic intrusives.........................

Intertectonic mafic intrusions . . . . . . . .

Later mafic intrusions. ..............

Older volcanic rocks.

Ghabar Group.

Metamorphism ...........................

Dynamothermal metamorphism ........

Metamorphism and granitization ........

Dynamic metamorphism

Thermal metamorphism

Synopsis of basement-rock geology . . . . . . .

Regional correlation of basement rocks .

Yemen . . . . . . . . .

Saudi Arabia.........

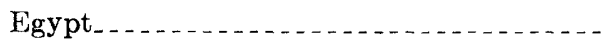

Eastern Aden Protectorate.............. . . .

Former Somaliland Protectorate..........

Summary ... . . . . . . . . . . . . . . .

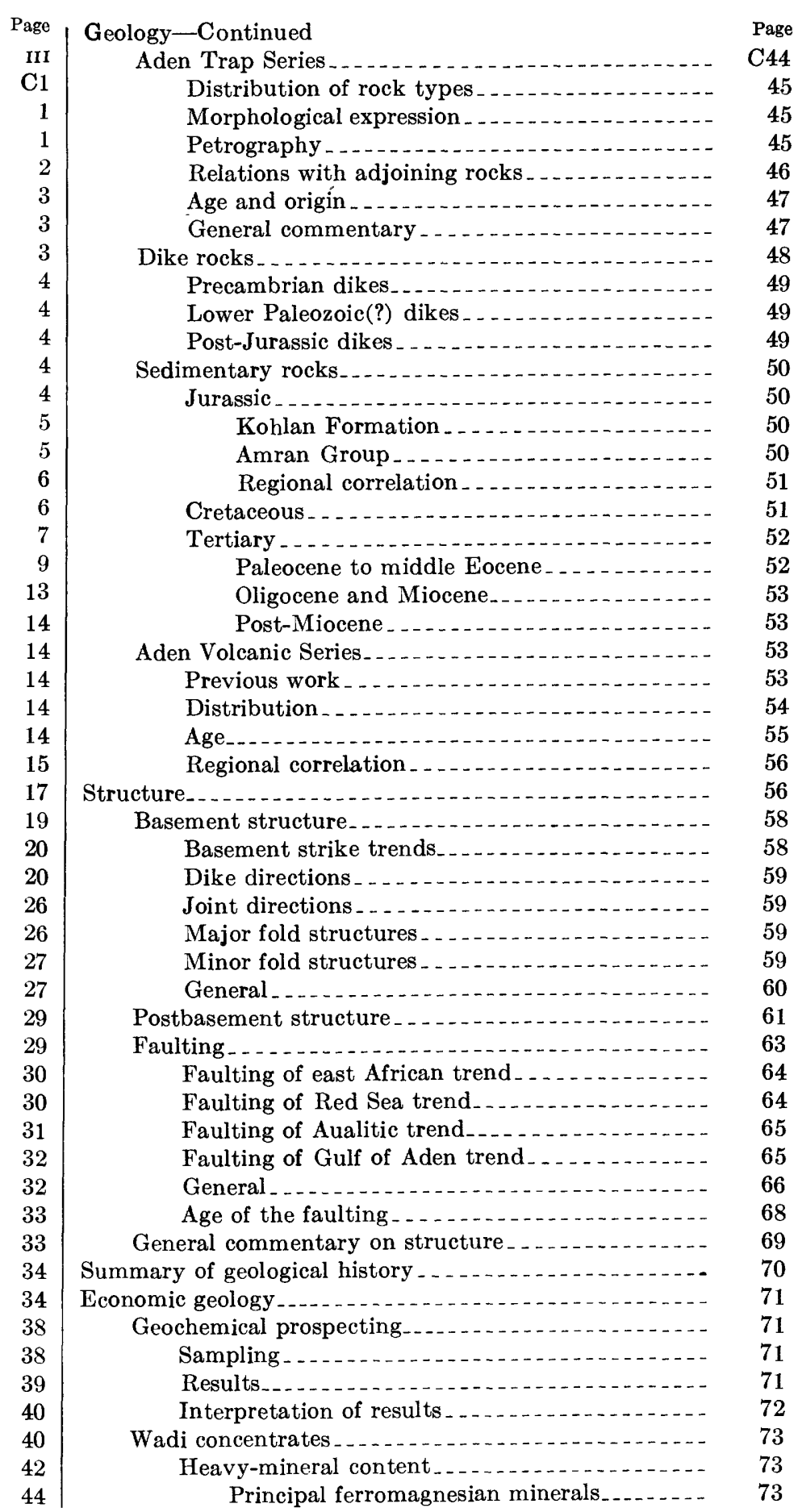

Page 
Economic geology-Continued

Wadi concentrates-Continued

Heavy-mineral content--Continued

Common accessory minerals.

Other minerals

Minerals of possible economic interest

Mineral resources............................

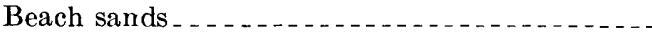

Bui'ding stone.

Copper minerals . . . . .

Other minerals

Portland and other cements.

Summary
Page

Water resources

Irrigation practice

Suggested methods for location and storage of water

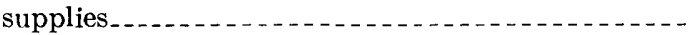

Well data

Prospects.

Gazetteer._.

Bibliography

Appendix-Age determination results, by N. J. Snelling - $\quad 93$

Selected references for appendix $\ldots \ldots$

\section{ILLUSTRATIONS}

Plate 1. Map showing structural trends in the western part of the Aden Protectorate

2. Map showing major structures of the Gulf of Aden region

Figure 1. Photograph of rock pediment veneered with coarse debris, near Al Khabr.

2. Cumulative curves of sand samples from Aden Protectorate

3. Map of Ramlat as Sab'atayn sand desert, southern Arabian Peninsula

4. Map of southern Arabian Peninsula showing Ar Rub'al Khālī sand desert._.

5-29. Photographs:

5. Quadrant-shaped sand dunes, Wādī al Jif'iyah $\ldots$

6. Relic bedding in schist, Wādi Gharish

7. Rocks of the Aden Metamorphic Group, 3 miles west of Șa'îd

8. Platy crystalline limestone interbedded with schist, Aden Metamorphic Group, As Sufāl........

9. Biotite schist and migmatite, 2 miles west of Şa'îd

10. Feldspathized biotite schist, 5 miles southeast of Al Kirsh

11. Hornblende schist impregnated with granitic material, Wādī al Kayfĩ .

12. Aerial view showing syntectonic granite, 15 miles south of $\mathrm{Nişāb}$

13. Feldspar porphyroblasts in biotite-chlorite schist, Jibāl al Aswad area

14. Feldspar porphyroblasts and thin quartz veins in biotite schist, west-central Jibāl al Aswad range - -

15. Intrusive granite, 6 miles south-southwest of Nișāb_

16. Aerial view showing intrusive granite of Ra's Burūm, Eastern Aden Protectorate................

17. Cretaceous sandstone overlying Jurassic limestone, Wādī Raybān .

18. Paleocene limestone overly ing Cretaceous sandstone, 6 miles north-northeast of Al Khabr .......

19. Basalt flows and volcanic cones of the Aden Volcanic Series, north of Karïf Shawrān, Bi'r 'Ali.....

20. Columnar basalt resting on terrace deposits, 11 miles north of Jil'ah

21. Aerial view showing the Aden Volcanic Series, north of Shuqrah

22. Fold in basement rocks, Wādi Ahwar.

23. Jurassic limestone faulted against schist along part of the 'Ataq fault zone, As Sufāl_...........

24. Aerial view of faults and folds in basement rocks, about 8 miles south-southeast of $\mathrm{Al} \mathrm{Mahfid.....}$

25. Pegmatite dikes in quartzite, Wādi Gharīsh

26. Workers exca vating salt at Lai'adin salt dome

27. Terracing with stone walls up to the watershed, Aḍ Dāli' area

28. Walled fields flanking large wadi, Aḍ Dāli' area.

29. Vegetation outlining the drainage pattern, Nişāb area

\section{TABLES}

TABLE 1. Rock units of Western Aden Protectorate and corresponding symbols on map of the Arabian Peninsula

2. Temperature and rainfall records

3. Main divisions of the basement rocks

4. Tentative correlation of basement and certain other rock units of Arabia and bordering regions.

5. Analysis of beach sand, Wādi Hajr, Eastern Protectorate

6. Composition of heavy-mineral fractions in beach sand, Wādi Hajr, Eastern Protectorate

7. Composition of limestones

8. Age determinations from former British Somaliand and Aden Protectorate

9. Age determinations on biotites from the Eastern Desert, United Arab Republic

10. Age determinations on micas from Arabia. 


\title{
GEOLOGY OF THE ARABIAN PENINSULA
}

\section{ADEN PROTECTORATE}

\author{
By J. E. G. W. Green wood and D. Bleackley ${ }^{1}$
}

\begin{abstract}
This account of the geology of Western Aden Protectorate and of major basement rock groups of Eastern Aden Protectorate is based on photogeological interpretation and on data from a field survey during November 1961 to February 1962. Attention is concentrated mainly upon igneous and metamorphic rocks.

An assemblage of metamorphosed sedimentary and mafic igneous rocks, to which the term "Aden Metamorphic Group" is assigned, rests upon older gneiss and is invaded by syntectonic granite with associated zones of metasomatism and migmatization. Subsequent to the main period of regional metamorphism but prior to a later period of stress, plutonic intrusions of dioritic and gabbroic rock occurred; these were followed after a short interval by intrusions of granite. Older volcanic rocks of the Eastern Aden Protectorate are regarded as approximately contemporaneous with mafic intrusions of this phase. Slightly metamorphosed sedimentary rocks of Wadi Ghabar, Eastern Protectorate, are thought to represent uppermost basement rocks. Posttectonic granites of early Paleozoic age and mafic plutonic rocks of possibly similar age are described. Rare intrusions of alkaline granite are thought to be of Tertiary age.
\end{abstract}

An early phase of regional (dynamothermal) metamorphism is distinguished from a later phase of essentially dynamic type. The highest grade of metamorphism recorded is that of the almandine-amphibolite facies. The effect of syntectonic granite invasion upon metamorphic grade is considered.

A synopsis of the geology of basement rocks is given, and regional correlation of basement rocks made, in which the Aden Metamorphic Group is tentatively correlated with the main part of the Medina Series, and the Ghabar Group of the Eastern Protectorate with the Fatima Series of Saudi Arabia.

A section on the Aden Trap Series includes petrographic examples and a discussion of relations with surrounding rocks and of the probable history of this phase of vulcanism. The age of the series is considered to be Late Cretaceous to Tertiary.

Dike rocks of three ages are present.

A relatively brief account of sedimentary rocks is largely based on the work of Beydoun in Eastern Aden Protectorate. Fossils collected from these rocks are listed.

An account is given of the Aden Volcanic Series, which consists mainly of basaltic lava flows of late Miocene, or Pliocene, to Recent age.

The structure of the Western Protectorate is considered in conjunction with that of the Eastern Protectorate. Basement

1 Of the Overseas Geological Surveys, London. strike trends, hitherto not known in detail, are discussed and an account of folding and foliation is given. Since at least Jurassic times the region has suffered intermittent epeirogenic uplif $t$ accompanied by faulting. A major phase of uplift of the main basement block of the Western Protectorate, associated with faulting principally along Red Sea trends, dates from late Cretaceous or early Tertiary times. A dominant feature in the Eastern Protectorate is the development of the Tertiary Hadhramut arch. Faulting of four main trends is described and a correspondence between these fault directions and those of the worldwide regmatic shear pattern is noted. Faulting in any one trend was not confined to a single period, and re-activation of ancient fault lines is suggested. A main phase of faulting of the Red Sea trend apparently occurred from Late Cretaceous until late Eocene times. A main phase of faulting of the Gulf of Aden trend dates from Miocene times. A general commentary on structure is given, in which it is suggested that the basement structural pattern results from the translation of a primary eastwest stress by transcurrent movements along ancient shear lines.

In a section on economic geology the results of geochemical prospecting and of concentrate analysis are interpreted and discussed; occurrences of economic minerals are described. No deposits of any great commercial interest have been found.

A section on water resources completes the account.

A discussion of age determination results by Dr. N. J. Snelling appears as an appendix.

\section{INTRODUCTION PURPOSE AND SCOPE}

The 1:2,000,000-scale geologic map of the Arabian Peninsula-prepared as an Arabian American Oil Company-United States Geological Survey project under the joint sponsorship of the Kingdom of Saudi Arabia, Ministry of Petroleum and Mineral Resources, and the U.S. Department of State-incorporates the Overseas Geological Surveys' 1:500,000 unpublished "Photogeological Map of the Aden Protectorate." The present report describes the geology of that part of the Arabian Peninsula which was mapped by the Overseas Geological Surveys (hereafter alternatively referred to as O.G.S.). The scope of the contribution, however, extends further than the explanation of geology shown on 
the map of the Arabian Peninsula. For example, the scale of the map precludes the portrayal of basement strike trends, which is a significant feature of the O.G.S. Photogeological Map. These structural lines are shown on illustrations accompanying this report. In brief, this account presents an outline of the more important findings of recent O.G.S. fieldwork in the Western Aden Protectorate, hereafter alternatively referred to as W.A.P.

Geological data from the O.G.S. Photogeological Map were necessarily presented for incorporation in the Arabian Peninsula geologic map before the results of the 1961-62 Aden field survey could be analyzed and collated. Thus, although amendments have been effected as much as possible in the Arabian Peninsula map, considerable amplification and changes are reflected in the present account. In particular, basement rock units have been further subdivided. Divisions shown in the geologic explanation of the Arabian Peninsula map and those of this account are equated in table 1, to which descriptive notes are added.

TABLE 1.-Rock units of Western Aden Protectorate and corresponding symbols on map of the Arabian Peninsula

\begin{tabular}{|c|c|c|}
\hline Age & Unit name used in this report & Map symbol \\
\hline \multirow{2}{*}{$\begin{array}{l}\text { Pliocene and } \\
\text { Pleistocene } \\
\text { to Recent }\end{array}$} & Eolian (dune sands) & Qe \\
\hline & $\begin{array}{l}\text { Superficial deposits, including allu- } \\
\text { vium, loess, silt, sand, gravel, and } \\
\text { terrace and raised beach deposits }\end{array}$ & Qu \\
\hline $\begin{array}{l}\text { Late Miocene or } \\
\text { Pliocene to Recent }\end{array}$ & Aden Volcanic Series & $\mathrm{Qa}$ \\
\hline \multirow{2}{*}{ Early Eocene } & Rus Formation & $\operatorname{Tr}$ \\
\hline & Jeza Formation & $\mathrm{Tj}$ \\
\hline Paleocene & Umm er Radhuma Formation & Tu \\
\hline \multirow{2}{*}{$\begin{array}{l}\text { Late Cretaceous } \\
\text { to Tertiary }\end{array}$} & Alkaline granite & Included in Pzp€g. \\
\hline & Aden Trap Series & Tkt \\
\hline Cretaceous & Tawilah Group & $\mathrm{Kt}$ \\
\hline Jurassic & $\begin{array}{l}\text { Ainran Group and Kohlan Forma- } \\
\text { tion }\end{array}$ & $\mathrm{Ju}$ \\
\hline Early Paleozoic(?) & Later mafic intrusions & Included in $\mathrm{dr}$. \\
\hline \multirow[t]{3}{*}{ Early Paleozoic } & Posttectonic calc-alkaline granite & \multirow[t]{2}{*}{ Included in Pzp€g. } \\
\hline & Intertectonic calc-alkaline granite & \\
\hline & $\begin{array}{l}\text { Intertectonic intermediate mafic } \\
\text { plutonic intrusions }\end{array}$ & Included in $d r$. \\
\hline \multirow[t]{3}{*}{ Precambrian } & Syntectonic granite & $\begin{array}{l}\text { Included mainly in gh } \\
\text { and } h r ; \text { also in part } \\
\text { in Pzp€g. }\end{array}$ \\
\hline & Aden Metamorphic Group & $\mathrm{mr}$ \\
\hline & Older gneiss & Not shown. \\
\hline
\end{tabular}

The geological work by O.G.S. in Aden Protectorate has been primarily concerned with igneous and metamorphic rocks; during the recent field survey, work on sedimentary rocks, which are sparse in W.A.P., was mainly in connection with possible economic mineral deposits. The relatively brief account of sedimentary rocks contained in this report is based largely on the divisions given by Beydoun $(1960,1961)$ in his descriptions of the sedimentary strata of Eastern Aden Protectorate, hereafter alternatively referred to as E.A.P.

The area covered by this report is largely included within the Western Protectorate, but in order to deal with all major basement-rock groups of the Protectorate, coastal areas of E.A.P. as far east as the longitude of Al Mukallā (about $49^{\circ} 08^{\prime}$ E.) are included. Similar$\mathrm{ly}$, the structure of W.A.P. cannot be considered in isolation, and for this reason also, there is some overlap into E.A.P.

\section{PREVIOUS WORK}

Volcanic rocks of the southwestern region of the Protectorate have been the subject of investigation since McMahon (1883) recorded his observations about the lavas of Aden. Lloyd (1910) reported on volcanic (and sedimentary) rocks seen on a journey from Aden to Ad Dāli‘. Lamare (1930) referred to the younger volcanic rocks of both W.A.P. and E.A.P. in his discussion of post-Cretaceous vulcanism of the Red Sea and bordering countries. Recently, Irving and Tarling (1961) gave a limited description of samples of volcanic rocks from Aden Peninsula, taken in connection with paleomagnetic work.

The early studies of volcanic rocks are not matched in work on the geology as a whole. The main contributions to the geology of the Protectorate are as follows.

Little (1925) made a geological survey of the $\mathrm{Al}$ Mukallā area of E.A.P. during 6 months in 1919-20. In his account he included sections on stratigraphy and economic geology, and he very briefly described crystalline (basement) rocks. The account was accompanied by a $1: 250,000$-scale geological map of the area extending westward to the Wādi Hajr.

Lamare (1936) made some reference to the geology of W.A.P. in his "Structure Geologique de l'Arabie." His generalized geological map, at a scale of 1 : $11,000,000$, is in need of considerable revision insofar as it applies to W.A.P. This work has greater value with reference to Yemen, although it appears that Lamare made a journey from the Yemen border to Aden via Aḍ Dāli'.

Wissmann, accompanied by Meulen, made notable expeditions in E.A.P. and W.A.P. in 1931 and 1939, the results of which were published in 1932 and 1942 . In the present report reference is made to some observations (Wissmann and others, 1942) on the crystalline (basement) rocks of W.A.P. No attempt was made to present a comprehensive description of basement rocks; and some general conclusions regarding the distribution of psammitic and metacalcareous rocks seem to have been based on too localized observations. Many significant observations on the structure of the Protector- 
ate and surrounding regions were made, together with a small-scale geological map showing structural lines. The map represented a valuable advance on previous knowledge, but, as may be expected, was not accurate in detail.

Jaques, working for the Colonial Geological Surveys (now O.G.S.) made a number of traverses in W.A.P. and E.A.P. during some 18 months' work in 1951 and 1952. Economic mineral deposits were investigated, but apparently nothing of commercial interest was found. Little systematic mapping was done; nevertheless, a geological reconnaissance map (scale $1: 1,000,000$ ) was prepared from observations made in the course of travel. This constituted a valuable provisional map of W.A.P.a region little known geologically. The map shows broad geological divisions but does not show structural lines or subdivision of basement rocks.

Most of the results of Jaques' work are embodied in unpublished notes. A very brief account of the geology of the Protectorate was published in 1954 (Jaques, 1954). Jaques observed that granitic rocks appear to be largely the result of granitization. His Cambrian and Ordovician rocks were not recognized in the recent survey.

By far the most comprehensive and detailed account of E.A.P. geology is that by Beydoun, whose work also overlaps into W.A.P. Beydoun made geological surveys of E.A.P. during six field seasons between 1953 and 1959, working for Iraq Petroleum Company and associated companies. Some of the results of this work, including geological maps, were published (Beydoun, 1960,1964 ), or appeared in thesis form (Beydoun, 1961).

Much of Beydoun's work is on the stratigraphy of sedimentary rocks and on structure, but he has made a considerable contribution to the geology of the basement rocks of E.A.P. Some of the views tentatively expressed, in particular with regard to the relation of his Ghabar Group to the rocks of Wādì Gharish and the relation of Tha'lab Group volcanic rocks to both of these, do not accord with the views formed by the present authors. In this connection, it is emphasized that the reconnaissance nature of the work done does not permit categoric conclusions to be drawn.

Some account of E.A.P. basement rocks is contained in a paper discussing the correlation of various basement rock groups of this region with those of former Somaliland Protectorate (Greenwood, 1961).

\section{PRESENT INVESTIGATIONS}

Following photogeological mapping and fieldwork in basement areas of former Somaliland Protectorate, the Photogeological Division of O.G.S. was assigned the work of producing a reconnaissance map of the western part of Aden Protectorate. This region was little known geologically, and apart from the small-scale provisional map prepared by Jaques, no geological maps were available. Through the cooperation of Iraq Petroleum Company, J. E. G. W. Greenwood of the Photogeological Division visited E.A.P. for about ten days at the end of 1958 and examined representative outcrops under the guidance of Z. R. Beydoun.

Photogeological interpretation started toward the end of 1959 and resulted in the production of a map covering approximately 31,000 square miles, including about 12,000 square miles of exposed igneous and metamorphic rocks. This map was completed in 1960, after some 18 months' work by one geologist.

\section{PHOTOGEOLOGICAL SURVEY}

The main object of the mapping was the delineation and subdivision of areas of igneous and metamorphic rocks in W.A.P., and also the plotting of major structural lines. The work was extended to cover the basement areas and associated sedimentary rocks of E.A.P. Interpretation was facilitated by previous knowledge of very similar rock types on the southern side of the Gulf of Aden, and by a preview of representative rocks in E.A.P.

Base maps were prepared from rectified photomosaics, from uncontrolled print laydowns, and from 1:100,000scale topographic maps where these were available (Directorate of Overseas Surveys (D.O.S.) 554, Ser. K667). The aerial photographs interpreted were taken by the Royal Air Force mainly between 1955-57, at a flying height of about 40,000 feet, the resulting scale being approximately $1: 80,000$. These were supplemented by larger scale photographs flown by the Royal Air Force in 1952. Geological maps were initially produced at a scale of $1: 250,000$ and subsequently compiled at 1:500,000.

It was possible to distinguish between intrusive granite and granitized rock; and also to differentiate between extrusive rocks of various ages. The final scale of the map precluded the detailed differentiation of the complex metamorphic rocks; major sedimentary divisions were plotted.

\section{FIELD SURVEY}

During the months of November 1961 to February 1962 a field survey was made in W.A.P. and the coastal areas of E.A.P. as far east as Al Mukallā, about one-quarter of the period being spent in the latter region. The survey party comprised the authors accompanied by local staff.

The object of the survey was to appraise the economic mineral potential of the region and to check and amplify the photogeological mapping. Prior to fieldwork, traverses covering critical geological areas and 
likely sites for mineral investigations were selected from the photogeological map. Both map and aerial photographs were used in the field.

During the survey an itinerary of some 3,300 miles was covered by Land Rover, and numerous foot traverses were made. Of some 300 rock specimens collected for intensive examination, about half have received detailed petrographic study. More than 300 samples were taken for geochemical analysis, and about 100 concentrate samples were obtained by panning material from selected wadis and beach sands. Specimens of economic minerals, including material potentially suitable for portland cement production, were taken for chemical analysis and assay, and large samples, mainly of granitic rock, were obtained for radiometric determination. A dionic water tester was used to ascertain the quality of water in springs and wells. A ratemeter was used during the survey without, however, any significant anomalies being detected.

\section{GENERAL}

It is apparent that geological knowledge of W.A.P stems to a considerable extent from photogeological work. Where tested in the field the photogeological map was found to be substantially correct, within the fairly broad framework adopted. Thus, further extrapolation on aerial photographs from the areas traversed is thought to be justified. Following concentrate examination and the collation of field observations and of results of petrographic study, data extracted from aerial photographs have been considerably amplified.

\section{ACKNOWIEDGMENTS}

The authors wish to express their appreciation and thanks to the following, who have contributed directly or indirectly to this account: To the Iraq Petroleum Co. for cooperation during a visit to E.A.P. in 1958, and in particular to Dr. Z. R. Beydoun for his able introduction to the geology of this area and general advice on conditions in the Protectorate; to the staff of the British Museum (Natural History) for paleontological determinations; to Mr. F. R. Gnauck of British Petroleum Co. Research Center, for palynological tests; to Professor F. Geukens of Louvain University and Dr. G. F. Brown of the U.S. Geological Survey for helpful discussions on geology of Yemen and Saudi Arabia, respectively; to the Aden Administration and members of the Aden Agriculture Department for assistance during the field survey, also to members of the Aden police and military escort; and to the Directorate of Overseas Surveys, Department of Technical Cooperation, for assistance in preparation of illustrations.

To. Mr. E. H. Beard, Principal, Mineral Resources Division, O.G.S., and staff, acknowledgments are due as follows: Dr. J. B. Allen examined and reported on petrographical specimens. The results are embodied in this account after interpretation in the light of field observations. Factual data on mineralogical composition and texture are referable to the petrographical report. The assignment to particular metamorphic facies is in most cases the responsibility of the present authors. Mr. J. A. Bain investigated and reported on panning concentrates; Mr. L. C. Chadwick made chemical analyses and assessed the suitability of limestone samples for portland cement manufacture; Messrs. D. R. Curry and P. J. Moore examined and reported on geochemical samples. In addition, economic minerals were investigated by the O.G.S. Mineral Resources Division. Data from all these sources are incorporated in this account.

Dr. N. J. Snelling, of the O.G.S. Age Determination Unit at Oxford University, provided data on rock samples from the Protectorate. Reference is also made to age determination by Dr. Snelling on rocks from former Somaliland Protectorate.

\section{GEOGRAPHY \\ AREA, LOCATION, AND POPULATION}

The total area of the Aden Protectorate is about 112,000 square miles. The area of the Western Protectorate has been estimated at some 19,000 square miles, but figures vary greatly since its boundaries are not all demarcated. The Western Protectorate is bounded to the west by Yemen, to the north by Yemen and the Rub' al Khāli, and to the south by the Gulf of Aden and the small area of Aden Colony. ${ }^{2}$

No census has ever been taken in the Aden Protectorate and figures are conjectural. The most recent estimate $^{3}$ puts the population of the Western Protectorate at 350,000 .

\section{TRANSPORTATION AND COMMUNICATIONS}

Surveys began in 1940 with a view to improving communications within the Western Protectorate, and a start was made on the three main trade routes leading from Yemen to Aden via Mufālis, Ta'izz and Aḍ Dāli', while at the same time improvements were made to the Aden-Lahj and Shuqrah-Ahwar roads. Roads have now been constructed from Shuqrah to Lawdar, extending to Mukalla in the Eastern Protectorate along the coast, and inland to the $\mathrm{Al}$ ' $\mathrm{Aw}$ a liq al 'Ulyā District and Bayhan. Recently, new roads have been opened from Aden to Al Kirsh, from Ad Dōli' to 'Awābil, and from Lawdar to Mukayrās, via

2 The relatively recently formed Federation of South Arabia includes former Aden Colony and the Al Wăhidi States (formerly of the Eastern Protectorate) and covers about 35,000 square miles.

${ }^{3}$ Aden report for the years 1957 and 1958, London, H.M. Stationery Office, 1961. 
the Thirah pass. Bituminized roads cover 110 miles in Aden Colony, and in the Abyan area gravel roads link the main centers of population.

Away from the coastal towns no road is of good quality, and the cost of maintenance of motor vehicles is excessive, owing to the nature of the surface of the roads and their commonly steep gradients. In many places it is possible to use dry wadi beds as motorways, although vehicles with four-wheel drive are highly desirable. In the gravel desert of, for example, Jaww Kudayf, motoring in any direction is feasible, and in sand deserts such as the Ramlat as Sab'atayn, routes can usually be found around and between dune chains. The motor route across the Ramlat as Sab'atayn from Nasr to Jabal ath Thaniyah continues to Mar'ib in Yemen, and probably coincides with the old incensecaravan road.

The camel caravan is the principal method of transport and a considerable proportion of the population is engaged for its livelihood in the carrying trade. Donkeys are used for carrying such articles as firewood and fodder, and are more generally used for riding. All settlements in the Protectorate are linked by caravan tracks: the most important routes are those leading from Aden to Yemen through Aș Șubayhì, Al 'Abdalī, Al Hawāshib, and Al Amīri territories, and those used by caravans from the Yâfi' Mountains, the Kawr al 'Awāliq, the Kawr al 'Awādhil, and the coastal route connecting Aden with Shuqrah, Ahwar, and Mukalla.

The Royal Air Force maintains a large airbase at Khormaksar (Aden) that is also used by the local Aden Airways Ltd., which provides a regular schedule of flights to a number of towns and intermittent or charter service to others.

\section{CLIMATE}

The Protectorate experiences temperatures in the higher range, the extremes being accentuated by the variety of its physical features. There is less range of temperature in the coastal areas than in the interior, but the former have a humid atmosphere and are liable to heavy dews and morning mists. The highlands have a wide range of temperatures between summer and winter, and the diurnal range may be great.

The hottest months are May to September; the peak is in June and July, when temperatures of more than $100{ }^{\circ} \mathrm{F}$ are frequent. Temperatures of $130{ }^{\circ} \mathrm{F}$ are reached in some localities. During the winter months low temperatures of $34{ }^{\circ} \mathrm{F}$ were measured in the interior by the authors, and frost has been reported; along the coast however, nothing less than $60^{\circ} \mathrm{F}$ has been recorded. (See table 2.)

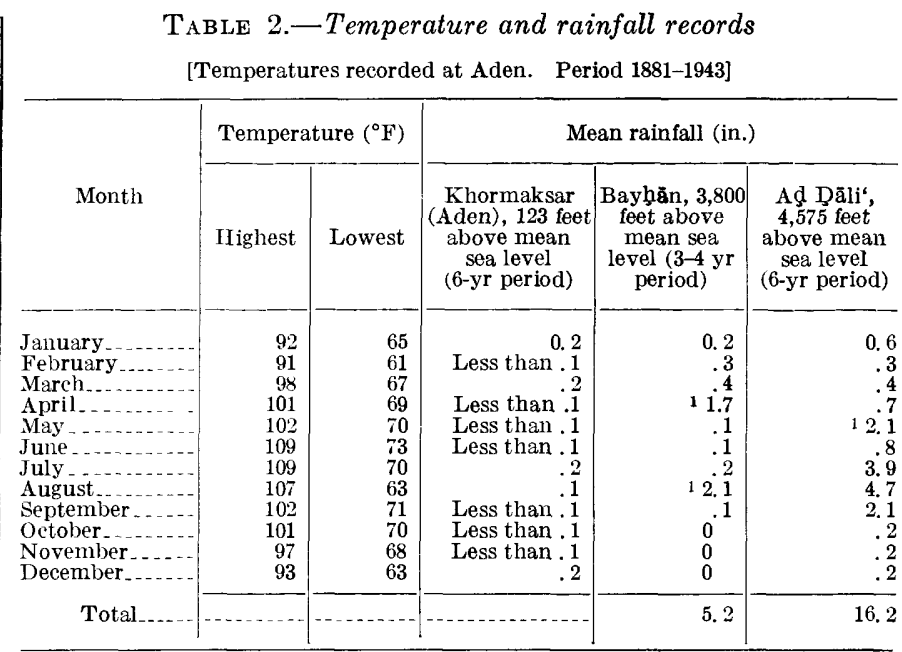

${ }^{1}$ In 1 year up to 5 in. fell in this month.

The prevailing winter wind in the Gulf of Aden is the easterly monsoon which swings southeasterly in the straits of Bāb al Mandab; in May the humidity sometimes rises and the winds are variable. From June to September they blow steadily from the west into the main current of the southwest monsoon in the Arabian Sea and bring occasional violent storms. In the interior the winds are to some extent affected by the hot center of the Arabian peninsula (see p. C9). A dry northerly wind which is known in Aden as the kawi (hot iron) blows occasionally in the Gulf of Aden during the southwest monsoon; in the interior this wind is called kharif or habub and usually occurs in the afternoons.

On the coastal plains and in the desert areas, sandstorms are fairly frequent and dust devils and mirages are common. Mists and haze are usual in the summer months, so visibility is poor.

Rainfall is irregular but more frequent in the winter months, except in the hilly interior. The total annual rainfall probably reaches 20 inches in parts of the interior, but owing to the very high rate of evaporation, added to the heavy demands for irrigation, only one perennial river reaches the coast (Wādi Hajr in the Eastern Protectorate). In the coastal areas the average annual rainfall is less than 2 inches; in exceptional years it has exceeded 5 inches, but much of this may fall in a single storm. (See table 2.)

\section{VEGETATION}

Data presented in this section are drawn largely from British Naval Intelligence Division's Geographical Handbook B.R. 527, titled "Western Arabia and the Red Sea," published by H.M. Stationery Office in 1946.

The plant distribution is conditioned by the incidence of rainfall and by the geology, topography, and drainage. The geographical range is more affected by rainfall than by temperature. On a smaller scale the micro- 
climate is of great significance and again is largely controlled by orographic factors such as relief and whether slopes are of north or south aspect, the temperatures of south-facing slopes being consistently higher than those facing north.

The vegetation of the coastal plain is largely determined by the topography because at many points, particularly in the Eastern Protectorate, the mountains reach the sea. The inner coastal plain carries a vegetation of open orchard type dominated by the longthorned acacia (Acacia spirocarpa). This is a deeprooting tree which taps perennial ground water and is largely independent of the local rainfall. Its green foliage persists throughout the year but may be reduced in the drier months.

In the hollows and silty pans between sand dunes, tussock grass (Panicum turgidum) and Cassiurus hirsutus are the dominant grasses. Halophy tic vegetation marks the beach fringe and the sporadic saltpans. The coconut palm is found in a narrow strip near the coast, from a point west of Aden to about the mouth of wadi Al Masilah in the Eastern Protectorate. There is a particularly luxuriant grow th of doum palms (Hyphaene thebaica) and Suaeda on the sand dunes between Ash Shaykh 'Uthmān and Aden Colony, particularly on the north shore of the Bay of Aden, and at Khormaksar. The commonest plant at Aden is a large kind of mignonette (Reseda amblycarpa), and the most conspicuous, a bushy green caper (Capparis galeata); next commonest are a large herbaceous spiderwort (Cleome brachycarpa) and the acacia (Acacia Edgeworthii).

A euphorbia (Euphorbia schimperi), the rummid of the Arabs, forms leafless intricately branched shrubs with pale-green fleshy branches. The fleshy trunks, naked branches, and fragrant rosy flowers of the "adan" bush (Adenium arabicum) make it conspicuous on the crags around Aden. This plant also occurs as high as 3,300 feet and more in the mountains of the Western Protectorate.

In the coastal wadis the acacia is the commonest tree, being replaced in drier wadis by the nebq (Zizyphus spina-christi); in sufficiently watered wadis the date palm is found. Frankincense grows in some of the smaller inland wadis, but the dominant tree is the tamarisk (Salvadora persica), particularly in sandy places. The ariata (Conocarpus erectus) is also found in certain wadis; it is frequently a constitutent of coastal mangrove formations.

The barren elevated jol of the Eastern Aden Protectorate carries little vegetation, but species of aloe and the dragon's blood tree (Dracaena serrulata) have been noted. In mountainous areas, close to the Yemen border, tall tamarisks are common; and in sufficiently watered wadis, clumps of a dwarf date palm, reputed to be Phoenix reclinata, and a low scrub of wild indigo (Indigofera) occur. In moister rock clefts, ferus, a horsetail, and selaginella have been reported.

Myrrh, as frankincense, is found in many parts of the Western Protectorate. This is a gum produced by stunted trees or shrubs of the genus Commiphora, and more than 50 years ago was collected in Fadli country, northeast of Aden.

The sand deserts, such as the Ramlat as Sab'atayn, are almost entirely devoid of trees and the vegetation consists mainly of grasses, such as artā (Calligonum comosum) and Aristida plumosa, with rare Cyperum sp. After rain, the sedge, Fagonia glutinosa, is the first to appear, followed by alab (Calligonum sp.), and later Dipterygium glaucum and occasionally Tribulus macropteris.

\section{TOPOGRAPHY, MORPHOLOGY, AND DRAINAGE}

The western part of Aden Protectorate comprises four well-marked physiographic zones, which are, from south to north:

1. The coastal plain.

2. The ramped plateaus composed of Cretaceous to Eocene trap sheets in the west, and the crystallines of the Kawr al'Awādhil and Kawr al'Awāliq in the east.

3. In the north of the Protectorate, the sand desert of the Ramlat as Sab'atayn and the gravel plains of the Jaww Kudayf and the Jaww Mulays.

4. In the extreme northeast, the plateau (jol) of Mesozoic and Tertiary sediments which, north of the Wādi Hadramawt, dip northward under the sands of the Rub'al Khālì.

\section{CoAstat pLaIN}

The present coastal plain, bordering the Gulf of Aden, is about 30 miles wide at its greatest extent north of Aden. To the east it narrows, and at $\mathrm{Ra}$ 's ar Rujaymah older volcanic rocks reach the sea. The plain is a depositional feature superimposed on a marine bench cut in Oligocene and Miocene sediments and crystalline rocks subsequent to the last movements of the rift fault blocks. The coastal plain has been built up in stages from alluvial material brought by innumerable short wadis which drain the ramped mountain ranges of the hinterland, as well as by the few major wadis, such as Wādī Tuban which rises in Yemen, Wādì Banā, Wādì Hasan (which formed the Abyan delta), Wādī Ahwar, and Wādì Mayfa'ah.

The finer grades of alluvial material occurring toward the seaward edge are redistributed by wind and sheet wash. A sorting action results and particles of the finest grade are washed into silty pans or removed by wind; sand-size particles are built up into an extensive 
series of dunes which are alined according to the regional and local wind regimes. Textbook examples of barchans and seif dunes can be found, together with transitional types resulting from diurnal changes in wind direction, from deflection of windstreams by rock masses and local areas of hot sand, and from occasional storms.

Winnowing by the wind leaves in situ the heavier alluvial material of fine gravel and of cobbles and boulders, which may reach 12 inches in diameter; older such deposits are frequently found as long ridges trending seaward and elevated slightly above the general level by removal of the finer flanking material. In many areas these gravel trains have coalesced and built up extensive stable flats which now carry an open orchard type of vegetation dominated by Acacia sp. They are frequently dissected by more recent, narrow gullies which may originate either on the high ground behind the coastal plain, or locally on the flats themselves.

Toward the mountain front, the material becomes coarser and poorly sorted. Remnants of coarse-gravel flats at various elevations above the present plain were observed at Al 'Anad, north of Aden, and at other points along the coast near the foot of the mountains. Gravel on the highest flats has developed a very dark patina and contains little interstitial material of finer grades; cemented layers of calcareous material sometimes produce a stratified effect. Intermittent Pleistocene to Recent uplift along the rift faults is probably responsible for these stepped terraces.

Lavas of late Miocene or Pliocene to Recent age overlie the coastal plain at various points, namely Jabal Kharaz, Aden Colony, east of Shuqrah, and near Bi'r 'Ali. Associated with them are tuffs and ash together with numerous cinder cones which rise to about 320 feet in height. The extinct crater of Kharif Shawrān, near Bi'r 'Alī, contains small blocks of ultrabasic rocks, including dunite, and its central depression holds a saltwater lake which is fringed with mangrove trees and is in hydraulic continuity with the sea. The recent age of the vulcanicity is attested by the fact that the lavas themselves have infilled certain wadis and are interbedded with, or rest upon, alluvial deposits. These lavas form the sea cliffs at Aden and reach the shore in the Bi'r 'Alī-Balhāf area.

In the Eastern Protectorate between Ra's ar Rujaymah and Burūm, a coastal plain is not developed and cliffs have been cut in basement rocks behind narrow beaches.

\section{RAMPED PLATEAUS}

Behind the coastal plain the country has a pronounced east-northeast grain, with local modification, largely due to faulting associated with the Gulf of Aden rift; this has determined the primary pattern of drainage and is responsible for the straight line of many wadi courses. The strike of basement foliation has had a subsidiary, albeit important, influence on the secondary drainage.

Northward from Aden the general level of the country rises through inclined and dissected steps toward the ramped plateau of Jabal Jihâf (near Aḍ Dāli') at about 8,000 feet. Farther north, in Yemen, the trap lava sheets, where unaffected by faulting, form an even plateau more than 9,800 feet in elevation. This corresponds broadly to the highest levels in the Kawr al 'Awādhil, seen typically at Mukayrās, and represents shallowly dissected remnants of a Paleozoic erosion surface which was subsequently faulted and folded mainly during the Tertiary earth movements. In the Kawr al 'Awāliq and Kawr al 'Awādhil ranges, ramp fault blocks that are normally south dipping but locally north dipping and that involve basement and Mesozoic rocks present a series of knife ridges on which dip slopes carrying consequent streams are actively downcutting. Most strike streams appear to be fault controlled, and headward erosion has resulted in capture by a few dominant streams such as Wädī Banā (Hasan) and Wādi Dayqah (Ahwar), which demonstrate both north and northeast flowing components.

In the northern part of the Kawr al 'Awāliq and Kawr al 'Awādhil, the drainage is to the north. In their upper reaches the wadis are narrow and stepsided, but their lower courses are heavily covered by alluvium where they debouch into the Jaww Kudayf. In this region, wadis from the Nișāb-Bayhān mountains and from Yemen swing northeast and east toward the line of the Wādi Hadramawt; west-flowing wadis such as Wādi Jirdān which have cut back into the escarpment forming the western limit of the jol also turn northward on entering the Jaww Kudayf at 'Iyādh. Their courses can be traced for some miles out from the mountains (for the Wādi Bayhān, 40-50 miles) but there appears to be no present flow of surface water; it is inferred, however, that there is a subterranean seepage into Wādi Haḑramawt along the former wadi courses.

This older drainage, in a hinterland which has been less affected by the Tertiary earth movement, shows a development of excessively wide flat-bottomed wadis, the width of which bears little relation to the present, or probably former, erosive ability of the intermittent flow of water. Wādī Durā is almost 3 miles wide east of Nişāb (Anșāb), and Wādī Markhah, between 3 and 6 miles wide. The processes of pedimentation and scarp retreat appear to be largely responsible and well-formed rock pediments flank many of the major wadis (fig. 1). This is a fairly general character- 


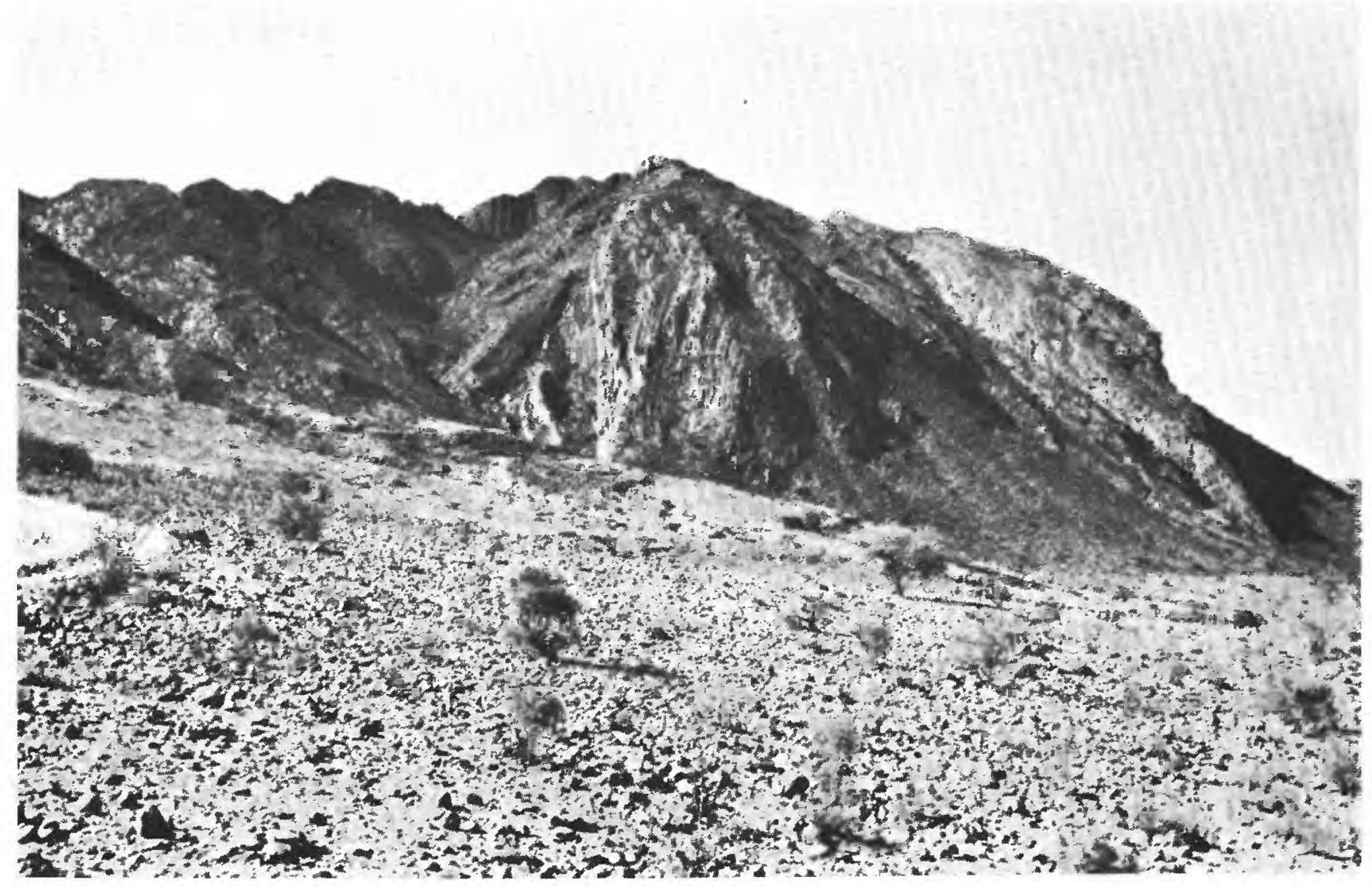

Figure 1.- Rock pediment veneered with coarse debris, near Al Khabr.

istic of Aden Protectorate wadis and some are stepped, the present wadis being $65-100$ feet below the level of the highest pediment. Clearly recent uplift has occurred on more than one occasion, inducing new cycles of erosion.

In metamorphic terrain, valley floors tend to open out, in places, into intermontane basins which may provide considerable areas of cultivable land. These basins are normally the result of differences in lithology; some such basins, however, have a more complex origin. The extensive plain around the town of Lawdar, for example, is limited on its northern side by the Thirah escarpment, which rises steeply to more than 6,500 feet above sea level. This plain appears to have originated as a fault scarp which has probably retreated from its original position. There is evidence that faulting has also occurred on the southern side and that this plain is, in fact, a small structural trough.

The widespread accumulations of alluvial material point to a time of moister climatic conditions, when the carrying capacity of the wadis was greater. This material, ranging from boulder to silt size, is now seen in terraces and outwash fans, which are a pronounced feature of the landscape. If the terrace deposits date from possible Pleistocene pluvial periods, the present downcutting phase of the wadis results from the subsequent decrease in the ratio of waste load to water, and from the steepened slope of the prelaid alluvial cones.

In areas where sediments and basement rocks are exposed, the morphology is closely related to the geology. Many granitic rocks give rise to areas of low relief and rounded form, and can be delimited on aerial photographs by these characteristics. Through exfoliation in concavo-convex shells, irregular masses and angular blocks resulting from jointing are reduced to rounded forms. White kaolinitic weathering products, together with residual quartzitic material, impart a light tone to aerial photographs of these areas. Younger, or post tectonic, granites are in many places outstanding, and the spinelike plugs east of Mudia are a good example. Certain schistose rocks tend to form sharply serrated mountains with rugged crests; some soft schistose rocks produce a thick mantle of waste having little fresh rock exposed and thus having rounded contours; in areas of more active erosion, a badland topography results. Intrusive dikes are common and result in narrow, elongated, and elevated ridges; these give a ribbed 
effect to the landscape in the Mukayrās area. Wellbedded limestones, capping fault blocks or flat-lying in the jol, are distinctive on aerial photographs as associations of level stripped surfaces.

To the north of the Kawr al 'Awāliq and Kawr al 'Awädhil the country falls away to the plains of the Jaww Kudayf and the Ramlat Sabas'atayn at about 3,000 feet above sea level. No active dramage exists, the main physical features being the extensive system of sand dunes.

\section{SAND DESERT AND GRAVEL PLAIN}

The center of the Arabian Peninsula is occupied by a vast area of gravel plains, with sand arranged in a variety of organized patterns as individual dunes, dune chains, and massifs. The main sand region is the famous $\mathrm{Rub}^{6}$ al Khālī, which covers almost a quarter million square miles, extending from just north of the 16 th parallel to about the 24 th parallel and from meridian $45^{\circ} \mathrm{E}$. to almost $57^{\circ} \mathrm{E}$.

South of the Rub' al Khāli there is an extensive gravel plain, on the order of 150,000 square miles in size, the southern part of which lies in W.A.P. This is bounded in the east by the limestone jol which runs north from 'Ataq to Shabwah and $\mathrm{Al}$ 'Abr and curves northeast and east into Dhofar. In the south lie the NişābBayhān mountains, of mainly Precambrian rocks, which swing round to the northwest and north into Yemen and Saudi Arabia.
The plain is divided into three regions by the dune sands of the Ramlat as Sab'atayn and by As Sawdā' scarp, which run west and north, respectively, from $\mathrm{Al}$ 'Abr. To the north of the Ramlat as Sab'atayn and separating it from the Rub' al Khāli is the Jaww al Mulays. Southeast of the Ramlat as Sab'atayn, between it and the Nișāb-Bayhann mountains, is the Jaww Kudayf, and the smaller Jaww Houdhì lies to the east of the As Sawdā' scarp (Bunker, 1953).

The routes from 'Ataq to Nişāb and from 'Ataqto Bayhān cross the Jaww Kudayf, which is level at about 3,000 feet above sea level. Surface particles in the size range of fine to medium sand have been largely removed by the wind; the resulting pavement is composed of fine gravel and coarse sand, the grains averaging about 1 millimeter in diameter. Figure 2 shows the size distribution in the first inch of depth, the finer grains, approaching $0.1 \mathrm{~mm}$ in diameter, coming from below a depth of one-half inch. The microrelief includes low parallel or subparallel ridges of coarser gravel which do not appear to be continuous over long distances. Associated with these are a few even coarser gravel particles as much as $30 \mathrm{~mm}$ in diameter, some of which show faceting, due to sandblast effect, and similar orientation of the dreikanter, which points to a long undisturbed period in situ. These gravels may have originated through the sorting action of sheet wash on alluvial material brought from the Yemen-Bayhān mountains during a former wetter period (a Pleistocene

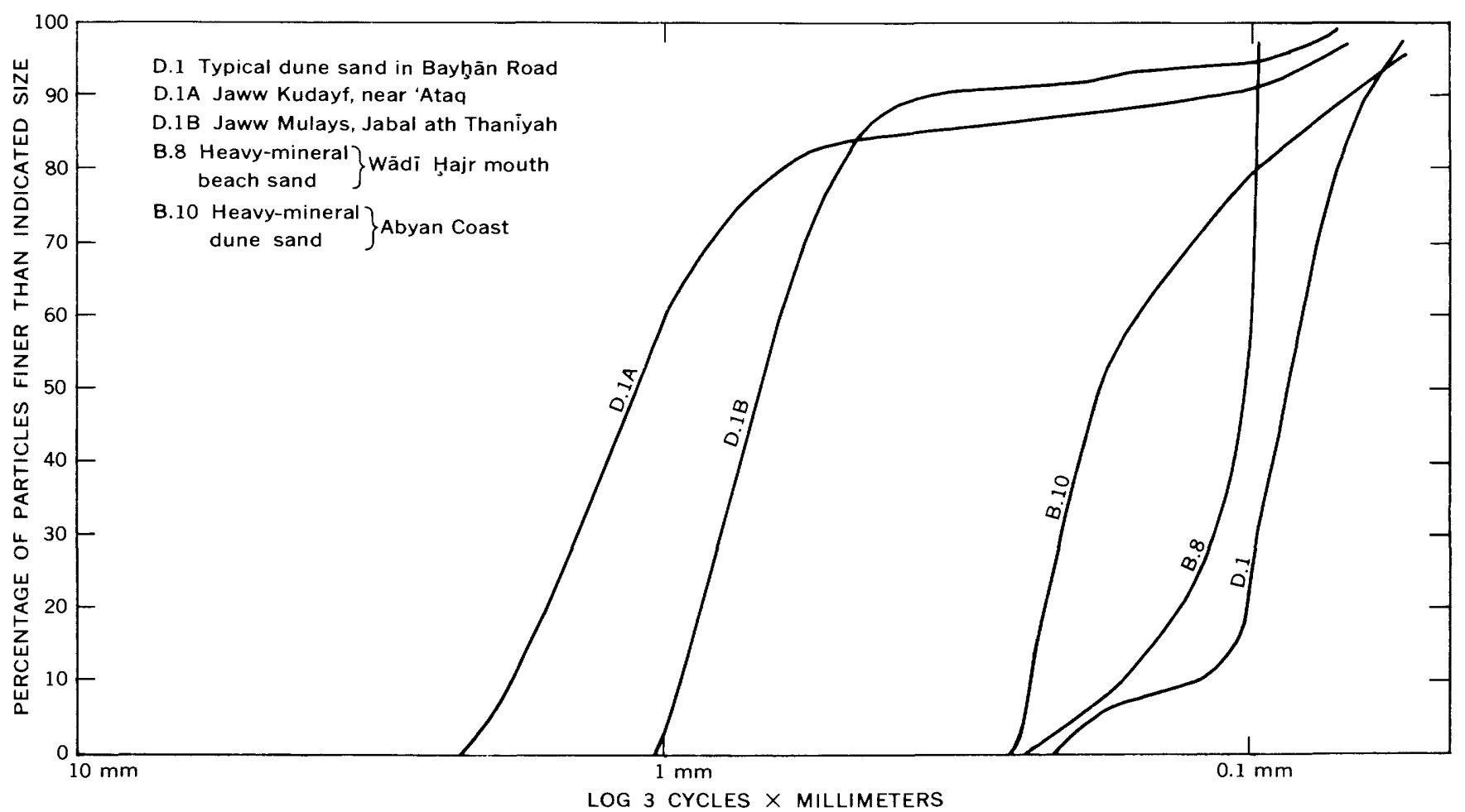

FIGURE 2.-Cumulative curves of sand samples from Aden Protectorate. 
pluvial?). Bunker (1953) described wadi channels, as much as 2 miles wide and 20 feet deep, and heavy alluvial gravels occurring in the northeastern part of the Mulays plains.

On the eastern side of the Jaww Kudayf, isolated low hills and mesas, such as An Nașr and Shabwah, stand as outliers of Mesozoic rocks, together with the salt domes of Milh Kharwah and 'Iyädh. The hills of the limestone jol are flanked by extensive rock pediments which are covered with a thick veneer of limestone boulders and coarse gravel, often lightly cemented into fairly stable terrace selvages. Again, the present cycle of erosion is not producing gravel deposits of this type, which therefore probably belong to a former more humid period. West-flowing wadis from the jol veer northwest and north toward the Wādi Hadramawt on entering the Jaww Kudayf, and it would be of interest to confirm that there is in fact an underground flow of water in this direction and to determine whether a permanent water table exists in this area (see "Water Resources" section, p. C82). It is possible that the former hydraulic network has now ceased to function and the control exercised by a universal base level is lost and replaced by independent bolsons of centripetal drainage.

The extremely level nature of the Mulays-Kudayf plain suggests a pediplain and an origin by pedimentation - the few outcrops of Precambrian rocks, such as Jabal ath Thaniyah, representing inselbergs. If this is so the plain probably represents an exhumed surface, as the basement rocks exposed beneath the Mesozoic and Tertiary sedimentary rocks to the southeast of 'Ataq were also base levelled in pre-Mesozoic timesalthough not to the high degree now apparent in the western plains. These sedimentary rocks at one time overlapped onto Precambrian basement rocks in the Yemen-western Saudi Arabia area, and the further period of planation followed the stripping back of the sedimentary cover. This process of eastward retreat and the origin of the western plains have been variously attributed to headwater erosion and river capture (Bunker, 1953), and to uplift of the basement rocks in the west associated with the Red Sea rift block faulting (Wissmann and others, 1942).

At Al 'Ubaylāt, the Bayhanan track enters the Ramlat as Sab'atayn, a sand-dune area lying south of the 16th parallel. It is 50-70 miles wide at its western end near the Yemen hills, and tapers to about 10 miles wide where it enters the Wādi Hadramawt. Here the dunes lose height and lateral extent, wedging out as isolated patches of dunes some 3 miles in width near Shibām. The Ramlat as Sab'atayn comprises a series of mainly parallel but sparsely convergent sand-dune chains (urq) separated by narrow flats of gravel, silt, or gypsum (shuq). Many of the individual ridges persist for several miles, their orientation swinging round from almost east in the An Nașr area to north-northeast near An Naqūb, where Wādì Bayhān emerges from the mountains. Near Shabwah and An Nașr, east-west routes have been used to cross the northern side of the Ramlat as Sab'atayn, and the present camel track, which was traversed by Land Rover as far as_Arayn and Jabal ath Thaniyah, is probably one of the old incense routes from the Hadramawt to Ma'rib in Yemen and to western Saudi Arabia. Several wadis flow east from the Yemen hills and disappear in the sands, but Wādi Bayhān persists for about 45 miles out from the mountain front, crossing the Ramlat as Sab'atayn to emerge onto the Jaww Kudayf Al 'Ubaylāt. It provides the only motorable route into Bayhān.

Outcrops protrude through the dunes at numerous points: a small cluster of Precambrian rocks occurs in the Jabal ath Thaniyah area and Mesozoic rocks appear at Arayan; also there is a salt dome some 40 miles northeast of An Nuqūb. Blocks of basalt and pumice bombs were found occasionally in the interdune flats, but their source is uncertain; they probably originate from the Yemen mountains in the Ma'rib area.

Apart from the few irregularities which are rapidly being reduced by exfoliation to the general level of the sand floor-where the rock is screened from the great diurnal variations in temperature-bedrock relief appears to be low. The orientation of the sand dunes must therefore depend on the wind velocity, direction, and frequency. Monsoon winds in the coastal areas are southwesterly in summer and southeasterly in winter, but local conditions within the peninsula of Arabia must be expected to cause some modifications. Heating up of the Rub' al Khāli sands in early summer may well cause an inflow of winds from the surrounding mountains. This appears to have contributed to purely local patterns in the dunes of the Ramlat as Sab'atayn, where the long axes of the dunes point away from the landmass at Bayhăn and near An Naşr (fig. 3); such a direction is opposed to the general $\mathrm{Rub}^{c}$ al Khäli trend (fig. 4). The general trend is common to the other four great sand regions of the world, namely, Australia, Egypt-Libya, and the two ergs of the western Sahara. In all these the main dune ridges are affected (1) by the westerly storm winds and (2) by the trade winds. As the tropics are approached the westerlies tend to decrease, and the trades begin to dominate. The result is a $90^{\circ}$ sweep round, so that the dune ridges end by approaching the equator from the northeast and southeast. Bagnold (oral commun., 1964) has suggested that the Ramlat as Sab'atayn change of direction, in the opposite sense, might be 


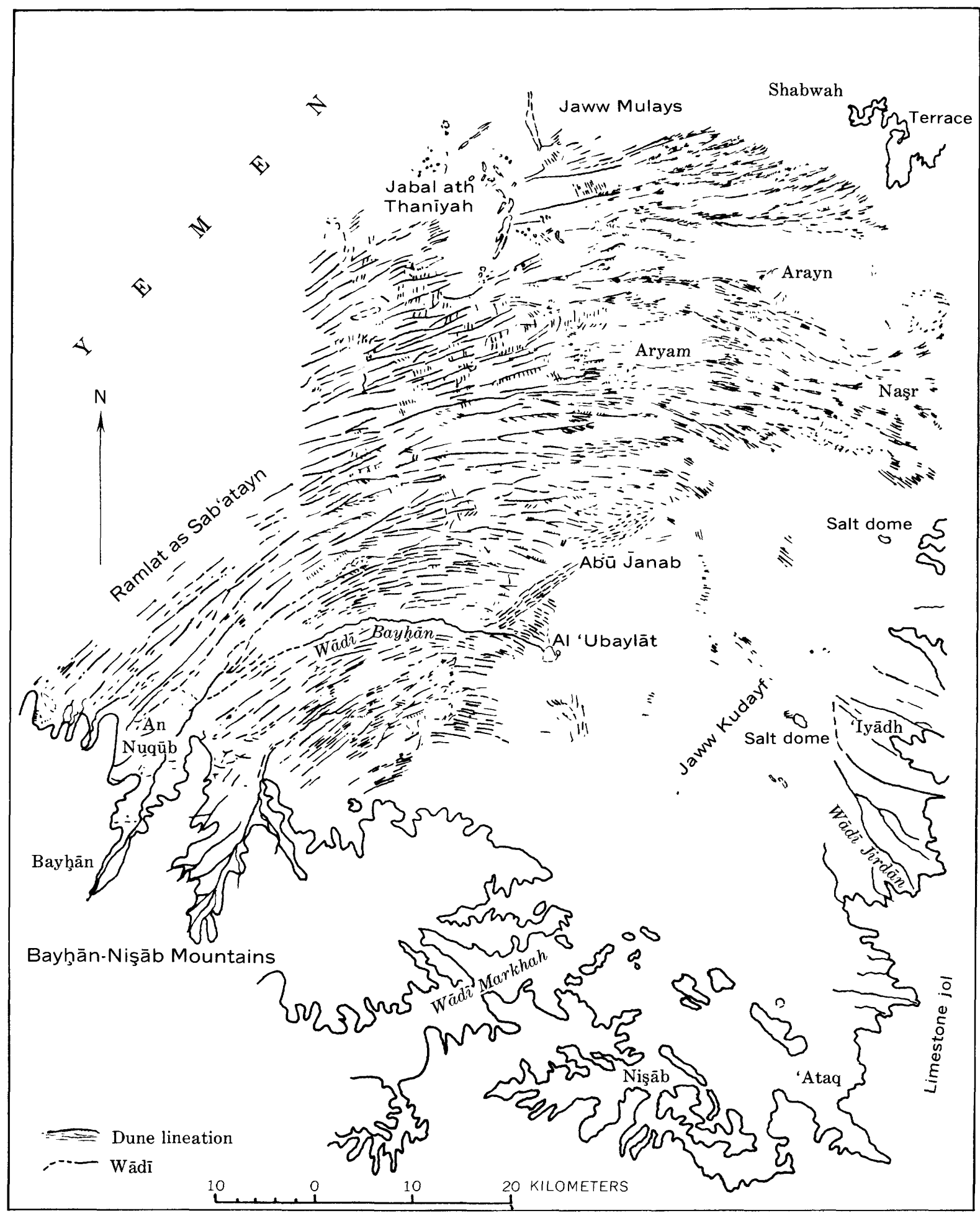

Frgure 3.-Ramlat as Sab‘atayn sand desert, southern Arabian Peninsula. 


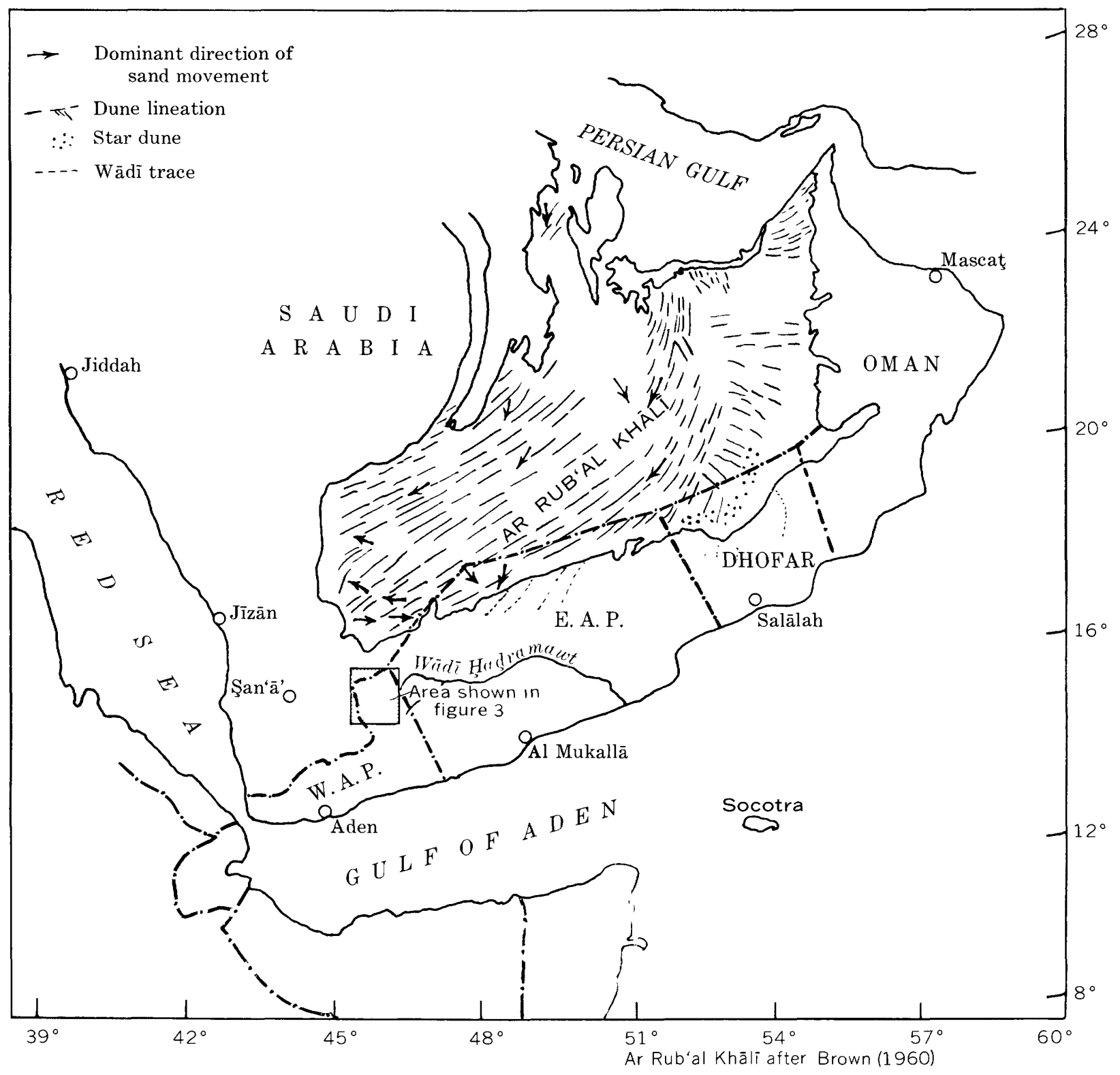

Figure 4.- Southern Arabian Peninsula showing Ar Rub'al Khālī sand desert.

explained by the effect of the Yemen mountains in sheltering the area from the westerlies, this sheltering being less to the north than in the south; at lat $15^{\circ} \mathrm{N}$. the northeast trade winds dominate, but farther north the westerlies dominate.

During a brief visit to Jabal ath Thaniyah the following wind directions were noted on February 1, 1962:

$$
\begin{aligned}
& 7 \text { a.m. . . . . . . . . North-northwesterly } \\
& 12 \text { noon . . . . . . . South-southeasterly } \\
& 4 \text { p.m. . . . . . . . Easterly } \\
& 8 \text { p.m . . . . . . . . Northerly }
\end{aligned}
$$

According to the local Bedouin the main wind directions are northerly in the mornings and southerly later in the day. The northerly winds are evidently the stronger since the slip faces were to the south or southeast, but the effect of southerly winds would be to check the lateral movement of the dune chains.

Bagnold (1938) stated that the sand-driving effect of wind is a cube function of the wind strength, and it is therefore not sufficient to know the relative number of occasions on which the wind blows from each point of the compass, since a few storms during the course of the year may dominate the wind regime as it affects dune formation and movement. The dune chains may be orientated in the direction of the main sand stream although this is at right angles to the two commonest wind directions in the Jabal ath Thaniyah area. In general, the northerly wind is the stronger 
and has resulted in asymmetrically shaped dunes having gentle slopes on the northern side and slip faces to the south and southeast. That some lateral movement of the whole dune chain takes place in this direction is attested by the fact that during the authors' visit a storm some miles away produced fresh winds which moved the foot of a dune slip face, adjacent to the camp, almost 1 foot in a few hours. The observed diurnal reversal of wind direction is an important factor tending toward stability and is a check on dune migration. The dune chains, between which Wädī Bayhān makes its way, also show evidence of movement in the direction at right angles to their long axes. On the western and northern sides of the wadi, bushes and discontinuous lines of artā (Calligonum comosum), now buried in sand to varying degrees, mark former channels of the wadi, which has been pushed progressively to the east and south by movement of the dune chains.

The main direction of sand movement is difficult to assess. In the Wādī Bayb̧ān area the dune chains wedge out in the mouths of the larger wadis and approach within a few hundred yards of the mountain foot, but touch it at one or two points only. There is no extensive piling of sand against the mountains as would occur if the bulk of the sand were moving in that direction. The mountains would deflect wind blowing toward them and the resulting turbulence would be expected to distort the dune pattern; it is clear from aerial photographs that the dunes diminish in size and fade out gradually as the mountains are approached. However, it is unlikely that the main dune movement is in the opposite direction, since the question of sand supply is introduced and no evidence was seen of the formation and movement of sandsize material in the mountains to the southwest.

That two wind components are probably necessary for dune formation, as suggested by Bagnold (1938), is shown by the dune pattern round Abū Janab immediately north of Al 'Ubaylāt. Here a small set of dunes lies at right angles to the Ramlat as Sab'atayn dune trend and must be a purely local phenomenon which results from one wind becoming dominant over the other in this particular area. It may also be the explanation, on a much larger scale, for the dunes to the north of Dhofar, shown in figure 4 , which lie at right angles to the Rub'al Khali i trend. Another local phenomenon which does not appear to have been described before was observed to the east of An Nuqūb in Wādi Bayḩān; this is a series of small quadrantshaped dunes restricted to a narrow zone on the eastern flank of a complex dune chain, sited in the mouth of Wādĩ al Jif'iyah (fig. 5). The dunes rest on a pavement of coarse gravel and are of constant size, about 33 feet wide and 3-4 feet high: two slip faces had been

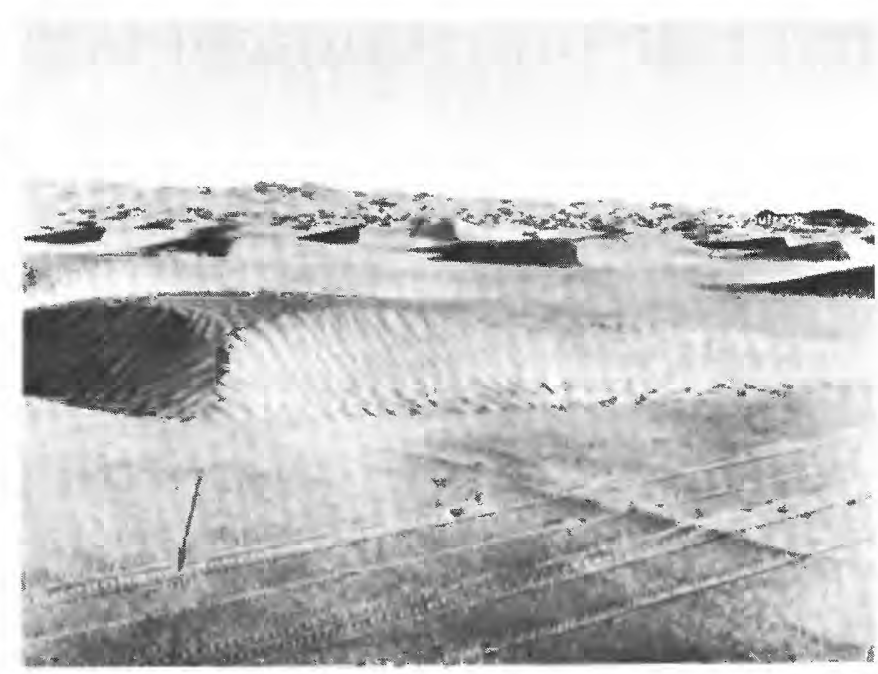

Figure 5.-Quadrant-shaped sand dunes. Wādī al Jif'iyah.

developed by northeasterly and northwesterly winds of equal strength, which caused a resultant movement of the dune system to the south. The rate of movement could be measured, at about 1 foot a year, against old Land Rover tracks, preserved in the pavement, over which some of the dunes had advanced.

\section{PLATEAU}

In the northeast, between the 47 th and 48 th parallels, the flat-lying or gently folded Mesozoic and Tertiary sedimentary rocks form an extensive plateau, or jol, its western boundary with the Jaww Kudayf being marked by a steep escarpment with a boulder- and scree-covered pediment. It is a tableland capped by mesas and cuestas of Eocene rocks, over 4,900 feet in elevation and deeply incised by a network of drainage that flows mainly into Wādī Hadramawt. Scarps bounding the mountains and flanking incised wadis are commonly steep and of considerable height. Massive sedimentary rocks give rise to sheer walls, and where bedding is pronounced and there is an alternation of resistant and less resistant beds, steplike benches occur.

Wādi Hadramawt, as well as many of the main wadis, has cut down through 1,000 feet of sedimentary rocks to expose Cretaceous beds. Tributary wadis with less erosive power are commonly arrested at various stages of downcutting by relatively more resistant beds and widen their floors at these levels by lateral planation. Extensive surfaces are formed in this way, often carrying small buttes and mesas as evidence of their mode of origin. These local planation surfaces are commonly veneered with a "pavement" or thin layer of residual gravel which is poorly sorted and often angular; such layers originated by flaking or 
cleaving from the underlying limestone and developed in the course of time a black patina of desert varnish. Over such surfaces, at other points, deflation is active in removing the finer particles of clay, silt, and sand size, leaving shallow depressions and ridges of harder material often carrying dreikanter and other faceted stones. After the wadis have cut below these surfaces, the hard limestone bands continue to influence the morphology in forming repeated free faces which contribute debris to talus cones on the flanks of the wadis.

\section{GEOLOGY}

\section{BASEMENT-ROCK UNITS AND PETROGRAPHY}

The term "basement" is applied to all rocks older than the unconformable cover of Jurassic and younger sedimentary rocks. An exception to this is made for certain post tectonic granites of Late Cretaceous or Tertiary age, which are conveniently considered with other earlier granites.

Statements concerning numbered specimens refer to petrographical data derived from examination of thin sections.

\section{OLDER GNEISS}

The oldest rocks exposed in the Protectorate are represented by orthogneiss of granitic and granodioritic composition. Rocks assigned to this older gneiss group give no indication of intrusive relations with adjoining rocks, and field examination has not revealed the presence of included metamorphic rocks, either partially migmatized or otherwise. The older gneiss group appears to be distinguishable from later syntectonic granite by the presence throughout the rock body of well-marked foliation (which may be absent from parts of the syntectonic granite); by the absence of gradational contacts with metamorphosed surrounding rocks (which the gneiss is assumed to underlie), and by the absence of feldspathization in such adjoining rocks.

Outcrops of older gneiss have been recognized near Tor al Baha in the southwest of the Protectorate, in the Șa'îd area, and about 6 miles east-southeast of Nișāb.

In the Tor al Baha area the gneiss is of two main types, the dominant gneiss being a fine- to mediumgrained rock with porphyritic feldspar augen, which is cut by more coarsely foliated gneiss. In specimen A43, described as a banded garnetiserous biotitehornblende-quartzo-feldspathic gneiss, much of the abundant feldspar is oligoclase, but sparse prominent phenocrysts of microcline perthite occur. Yellow or colorless garnet is infrequent. The appearance of the rock suggests a deformed granodiorite (or quartz diorite) and supports the assumption that syntectonic granitic invasion resulted in alteration of older gneiss. In this connection the presence of feldspathic porphyroblasts of potassic composition, perhaps due to granitization, is relevant.

A limited exposure of older gneiss occurs on the northeast periphery of the Șa'id granite, some $4 \frac{1}{1} 2$ miles north of Yashbum. A specimen of this rock (A134) shows a granite gneiss of abundant quartz, tending to be granulated, late microcline, and oligoclase. Petrographic examination suggests an origin through deformation of a previous granite. Since in the Şa'îd area syntectonic granite is known, it is likely that a later invasion of this rock affected the earlier gneiss and possibly accounts for the late appearance of microcline in the gneiss.

In the Nişāb area a granodiorite gneiss of quartz, andesine, hornblende, and clinopyroxene forms a small outcrop. Horneblende and clinopyroxene tend to occur in bands. The foliation of the gneiss appears to be primary. In this rock no evidence of shear or cataclasis, apart from slight strain effects in the quartz, is seen. This is perhaps difficult to reconcile with the postulated early age of the gneiss unless this formed a mass resistant to subsequent tectonic stress.

The evidence is not strong but is thought adequate to warrant a tentative separation of the older gneiss group from later basement rocks.

\section{ADEN METAMORPHIC GROUP}

The term "Aden Metamorphic Group" has been introduced to refer to a group of metamorphic rocks which makes up a large part of the Protectorate basement assemblage. The group comprises metamorphosed sedimentary and mafic igneous rocks with some volcanic representatives.

The original sedimentary deposits included types ranging from coarse- to fine-grained arenaceous rocks to fine argillaceous deposits. Rocks representing variable admixtures of argillaceous and arenaceous material are common. Calcareous-dolomitic phases were well marked and common; they resulted in limestones and dolomitic limestones, many of considerable purity, and in calcareous shales and grits.

No horizons of unconformity have yet been established in the Precambrian metamorphic rocks of the Western Protectorate, and in the absence of evidence to the contrary the rocks are considered to be members of one group, excepting only the older gneiss (described earlier). Rocks of the Aden Metamorphic Group are described under four main headings, namely pelitic, psammitic, metacalcareous, and metamorphosed mafic igneous rocks.

\section{PELITIC ROCKS}

Metamorphic rocks derived from argillaceous and impure argillaceous sediments form a component of 
the Aden Metamorphic Group widely distributed throughout W.A.P. and the older basement-rock areas of E.A.P.

At As Sufāl, Wādī Habbān, garnet-muscovitebiotite schist is interbanded with quartzitic and metacalcareous rocks and demonstrates metamorphism in the higher part of the green schist facies. In a specimen of this rock (A129) polymetamorphism is shown by the crumpling of an original schistosity, by the presence of two generations of quartz and mica, and by the bending of mica microporphyroblasts. In the same area are garnetiferous biotite-epidote schists, in which the presence of oligoclasic plagioclase indicates a higher grade of metamorphism in the lowest part of the almandine-amphibolite facies. The breakdown of garnet, which lacks crystal outlines and shows marginal alteration to chlorite, suggests retrograde metamorphism. The specimens from As Sufăl were taken from a belt of steeply dipping metamorphic rocks extending from As Sufāl northwest to near 'Ataq. The presence of polymetamorphic rocks and of higher grade metamorphism in rocks of this belt makes it improbable that low-grade quartz-chlorite and chlorite-epidote schists, well developed in this belt, could represent an upper less metamorphosed division of the Aden Metamorphic Group.

Garnet-epidote-biotite schist containing abundant sodic oligoclase crops out in a locality some 5 miles south-southeast of 'Ataq, where it flanks an intrusion of little altered gabbroic rock considered to be of later date. The schist is metamorphosed in the almandineamphibolite facies. Prisms of actinolitic amphibole tend to be associated with biotite in this rock, but they appear to be too rare to justify assumption of an igneous origin for the schist. The possibility of admixture of volcanic material in the original sediment is indicated.

In the Wādī Gharish area of E.A.P. quartz-muscovite and quartz-biotite schists occur in an assemblage of basement rocks comparable in lithology and metamorphic state with the basement of W.A.P. On the right bank of the wadi, about 1 mile below the Jurassic limestone outcrop of Jabal Suwayqah, an outcrop of garnetstaurolite-biotite-quartz-muscovite schist (A229) shows the highest grade of metamorphism determined in pelitic rocks of the Protectorate, that is, metamorphism in the lower subfacies of the almandine-amphibolite facies. Relic bedding in this rock is clearly marked by layers of garnet- and biotite-rich bands. (See fig. 6.)

Apart from the localities mentioned above, pelitic and semipelitic rocks occur in many areas of the Western Protectorate, mainly as biotite, biotite-muscovite, and quartz-biotite-muscovite schists. Metamorphism varying from that appropriate to the quartz-albiteepidote subfacies of the green schist facies to that ap- propriate to the lower almandine-amphibolite facies is shown. Polymetamorphism is indicated in some of these rocks. Localities in which these pelitic rocks have been recorded include 'Awābil, Kirsh, Wādī Raybān, Mūdiyah, Bayḩān, and Wādī Aḩwar.

\section{PSAMMITIC ROCKS}

Psammitic rocks are in numerous localities and their distribution is such as to suggest that they are not confined to any particular horizon of the basement succession. The thickness of individual bands, which like those of other rocks of the Aden Metamorphic Group are commonly steeply dipping to vertical, was estimated to range between 30 and 100 feet.

The original sediments, from which most of the psammitic rocks were derived, appear to have been either a quartzo-feldspathic or an arkosic type. Less common and thinner bands of crystalline quartzite represent pure siliceous sediments. A number of the psammitic outcrops examined may represent metamorphosed granites. Rocks resulting from the metamorphism of argillaceous and calcareous sandstones are also present.

The main rock types included in this group are quartzites of varying purity, quartz, and quartzo-feldspathic schists, granulites, and metamorphosed calcareous grits. Quartzites are commonly associated with metacalcareous rocks, but in general the psammites may occur interbanded with all types of basement metamorphics.

In some of the psammitic rocks garnet is developed, one sample being a garnet-biotite-quartzo-feldspathic schist from Wādī Gharīsh Eastern Protectorate (A228). Shearing and fracture cleavage in these rocks is also recorded; the fracture cleavage is well developed in platy quartzite of the eastern Wādī Gharish area. Some psammitic rocks show well-developed feldspathization as noted in the following discussion.

Steeply dipping psammitic rocks form positive topographic features, and the purer forms of quartzite are, with crystalline limestone, the most resistant rocks of the region (fig. 7).

Specimen A120, from Wādĩ al Jahr, 15 miles west of Nüsah, is described as a banded garnetiferous muscovite psammite and is one of the few rocks examined in which tourmaline occurs. In this specimen the mineral occurs commonly in crystals as much as $0.3 \mathrm{~mm}$ in length that show pleochroism from dark green to yellow brown. Some of the laminations in this rock are entirely quartzose; intervening layers consist of muscovite, twinned albitic plagioclase, quartz, and potassium feldspar. Irregular muscovite flakes enclosing groundmass minerals are clearly porphyroblastic. The preservation of a recumbent microfold in one of the bands of this rock shows that all the bands represent pinched out micro- 


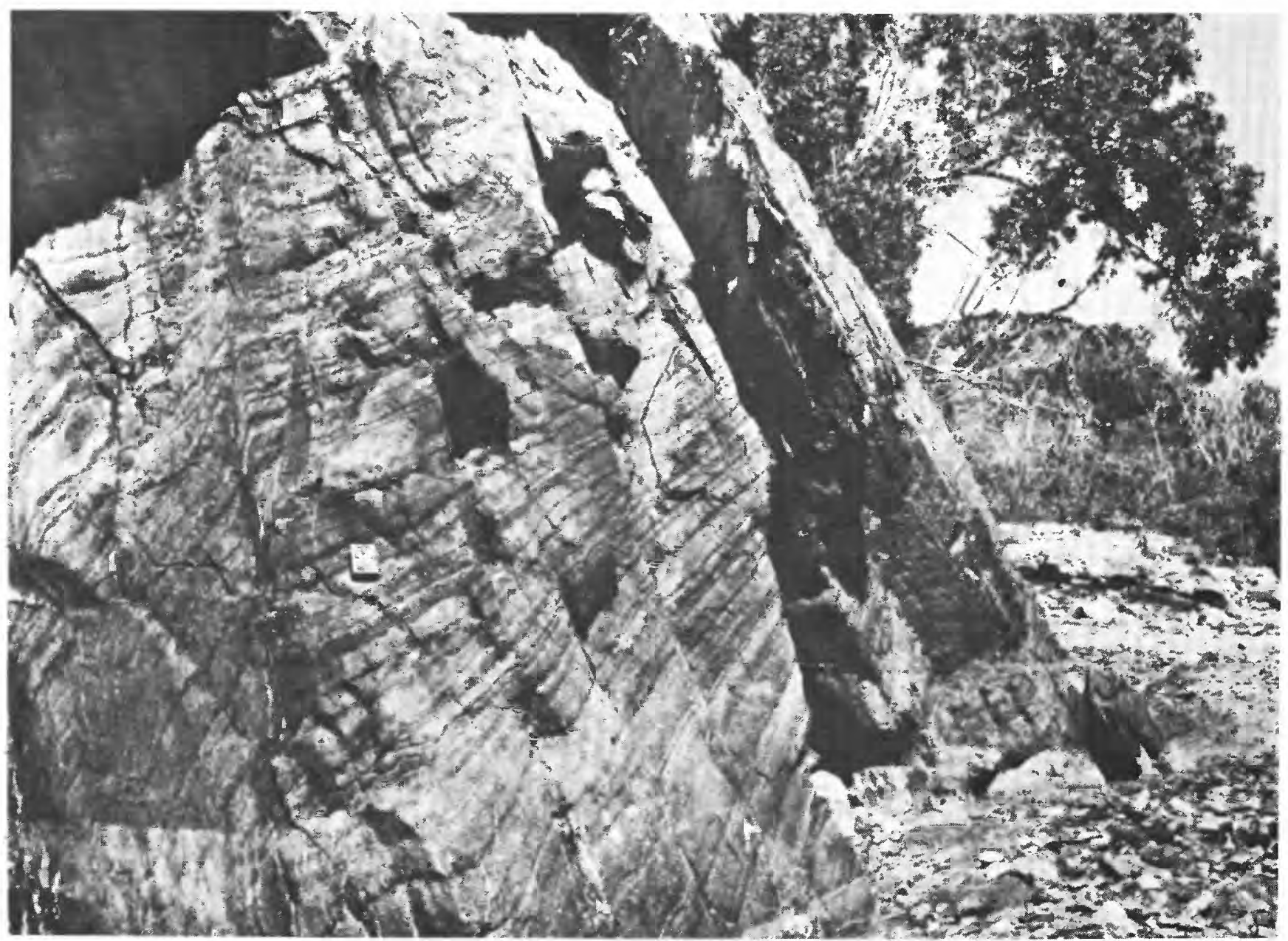

FIgURe 6.-Relic bedding in schist, Wādĩ Gharīsh. Matchbox shows scale.

folds and implies that the banding is of metamorphic origin. Polymetamorphism is indicated by the puckering of a previous schistosity

On the south bank of Wādi Khawrah nearly opposite the town of this name occurs a banded epidote-quartz rock, or epidosite, in which an aggregate of quartz and granular epidote passes into a fine aggregate of quartzepidote, oligoclase, and minor muscovite (A154). This rock is considered to represent a metamorphosed calcareous grit.

The metamorphism of an arkosic sediment is exemplified by deformed schistose quartzo-feldspathic rock exposed to the south of An Nuqūb in the Bayhān area. The specimen (A186) shows microcline, orthoclase, and albitized plagioclase in a granular groundmass. Palegreen chlorite is plentiful; red-brown biotite and epidote are present in small quantity.

Between Nișāb and Khawrah and to the southwest of Nișāb are coarse-grained platy impure quartzites containing scattered flakes and discontinuous folia of biotite. Purer white quartzite is interbanded with tremolite marble and biotite schist in the same area. The quartz appears to have recrystallized during metamorphism and is elongated parallel to the schistosity of adjoining rocks. In the range of hills some 6 miles northeast of Nişāb, quartzite and quartz-garnet-biotite schist are interbanded with platy crystalline limestone. Quartzite and crystalline limestone occur interbanded in similar ridges on the margin of the Ramlat as Sab'atayn, some 13 miles north of Nișāb.

Quartzites and quartz schists make up a considerable part of the northwestward-trending belt of metamorphic rocks between As Sufāl and 'Ataq. The quartzites include both massive dense blue-gray rocks and platy bedded types which are interbanded with chlorite and quartz-chlorite schists. In the northwest part of this belt, quartz schists are finely intercalated with chlorite schists, individual bands being only inches thick.

Granulites are represented in the belt of metamorphic rock that intersects the Jibāl an Nisīyin granite block. These granulites are derived from feldspathic sandstones and consist of an aggregate of quartz and feldspar, 


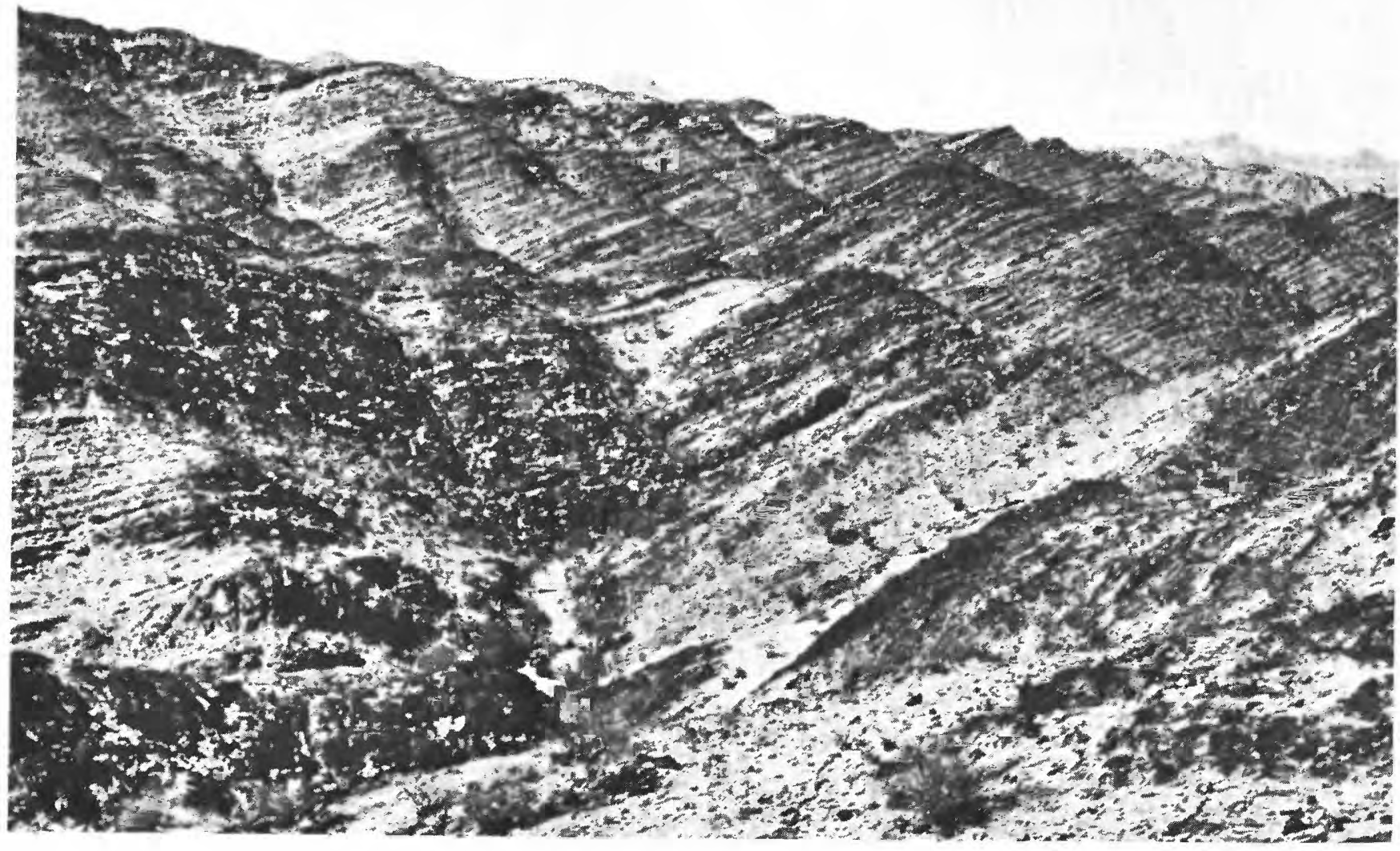

FIGURE 7.-Rocks of the Aden Metamorphic Group, 3 miles west of Şa'ìd.

with biotite flakes and scattered crystals of garnet. In some types, devoid of garnet, muscovite occurs with the biotite. A rough schistosity is imparted to the muscovite and biotite by the micas. Biotite granulites also occur in Wādi Ahwar.

Feldspathization of fine-grained quartzite has occurred in the Wàdi Ahwar area, as shown by the production of microcline and plagioclase porphyroblasts as much as $6 \mathrm{~mm}$ in diameter in a groundmass in which the average size is $1 \mathrm{~mm}$ or less. Feldspathization was also recorded in the area northeast of Nișāb.

\section{METACALCAREOUS ROCKS}

Metacalcareous rocks occur in most of the basementrock areas visited, and even allowing for possible repetition by folding, their wide distribution indicates repeated calcareous depositional phases. The metacalcareous rocks are interbanded with other basement components and range in thickness from 6 to 180 feet or more. The rocks may occur in massive form, but in several areas they show a platy or laminated character. Rock types include marble or crystalline limestone, ophicalcite, tremolite schist, and calcsilicate rocks. A feature of note is the high proportion of magnesia-rich (dolomitic) limestone. In general, the metacalcareous rocks are highly resistant to weathering: in the arid climate of the Protectorate and commonly form marked positive topographic features.

Thermal metamorphism of nonmagnesian slightly impure limestone is shown by an outcrop of banded idocrase-wollastonite marble adjoining the granite of Jabal al Munif, Al 'Anad. A specimen of this rock (A18) shows 2-mm-thick bands of crystalline idocrase marble alternating with thinner bands of columnar wollastonite and idocrase. Much of the irregular idocrase is full of inclusions; some calcite occurs.

Thermal metamorphism of impure magnesian limestone is exemplified in ophicalcite from Wādĩ Milh some 12 miles southwest of Lawdar. The specimen (A81) shows serpentine pseudomorphs after forsterite set in euhedral dolomite. In the same area, ophicalcite containing some chlorite is in contact with a pegmatite dike. The metamorphism of ophicalcite and similar rocks is probably connected with the invasion of granite during the main syntectonic granite phase. In the 
assemblage of pelitic and mafic schists and metacalcareous rocks of this area granitic bands are common.

Regional metamorphism, of calcareous sedimentary rocks resulted in a fine-grained tremolite schist at Wādi Raybān, southwest of Lawdar. In the same area is plagioclase-diopside-scapolite gneiss in which colorless euhedral diopside is surrounded by euhedral scapolite and unaltered oligoclase (A77). Birefringence indicates a lime-bearing scapolite. Small apatite crystals, common sphene, and sporadic garnet occur. The presence of disseminated pyrrhotite, which is the common sulfide mineral in higher grade regional metamorphism of calcareous rocks, confirms other evidence for metamorphism in the almandine-amphibolite facies. Petrographic study indicates that scapolite is in equilibrium with the feldspar in this rock.

A lower grade of metamorphism is indicated in epidote-quartz rock that forms a hill about $1 \frac{1}{2}$ miles northeast of Kawrah. This rock (A159) is composed of euhedral epidote in a granular fabric of quartz. It is thought to be derived from a calc-arenaceous sedimentary rock but might possibly represent an epidotized quartizite.

The wide distribution of metacalcareous rocks precludes description of all the observed outcrops, but some account of the more important of these is given below.

A traverse along Wādi Durā to the southwest of Nişāb showed several bands of metacalcareous rocks in the basement assemblage of pelitic schists and quartzo-feldspathic schists and gneisses. A specimen from a 6 -foot-thick band in quartz-biotite schist shows white to pink coarsely crystalline marble with sporadic flakes of muscovite and chlorite and a little quartz and feldspar. In the same area phlologopite-tremolitedolomite marble, mainly consisting of crystalline dolomite, represents an altered impure magnesian limestone.

At As Sufāl, east of Yashbum, dolomitic limestone is interbedded, in laminae ranging in thickness from $1 / 4$ inch to 6 inches, with quartz-chlorite schist (fig. 8). The overall width of the calcareous series is here about 30 feet but may reach 120 feet in the northwestern part of the same belt of metamorphic rocks. A specimen of the limestone shows patches of quartz and a little chlorite. The quartz shows strain effects, and evidence of shearing stress is seen in the rock.

The Jabal ath Thaniyah range in the Ramlat as Sab'atayn is composed largely of crystalline limestone, commonly dolomitic. The folded and generally steeply dipping limestone is associated with bands of amphibolite, hornblende-chlorite-epidote schist, and talcose schist. An east to west traverse over the northern part of the main ridge crossed an unaltered andesitic dike followed by a band of dolomitic marble which is

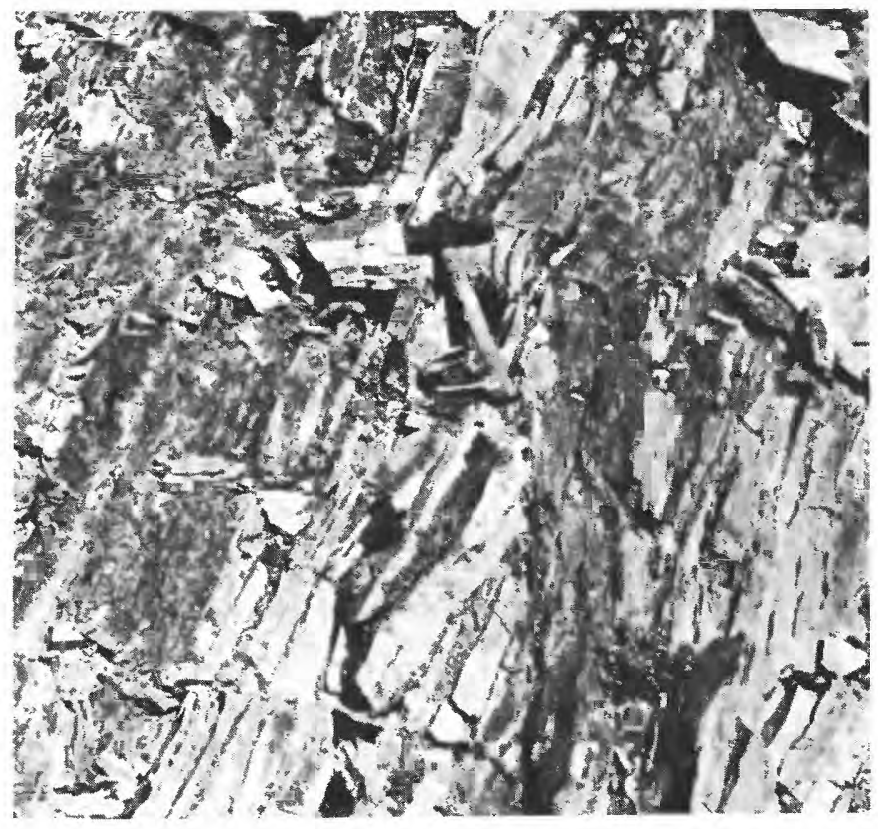

Figure 8.-Platy crystalline limestone interbedded with schist, Aden Metamorphic Group, As Sufāl.

pink to white and about 170 feet thick. This band is followed by a band of gray marble some 6 feet thick, a specimen of which (A206) shows areas of granular quartz in a turbid mass of dolomite. To the west occurs a band of dark hornblendic rock some 30 feet thick. This may be an amphibolite derived from gabbro, or may represent an altered calcareous shale. The metamorphic grade indicated is fairly high (almandine-amphibolite facies). In contact with this rock to the west is a band of white laminated crystalline limestone about 45 feet thick, in which the laminae are about 1 inch thick. This band is followed by blue laminated or platy crystalline limestone with intercalated brown and white limestone, about 180 feet thick. The traverse did not cross the whole ridge.

The thickness of metacalcareous rocks in the Jabal ath Thaniyah range is greater than seen elsewhere in the Protectorate, but these rocks are associated with metamorphic rocks comparable in grade and lithology with those in other outcrops of the Aden Metamorphic Group.

Crystalline limestone forms resistant bands in the granite of Mukayrās, Nișāb, and Șa'īd. Extensive exposures of this limestone occur in the hill ridges 6 miles northwest of Nişāb and in the Bayhān area. Minor bands were seen in Wādì Ahwar and in the metamorphic belt of the Jibāl an Nisīyin block. In Wādì Gharīsh, E.A.P., metamorphosed impure dolomitic limestone containing flakes of phlogopite and chlorite is present, and also metamorphosed calcareous sandstone. 


\section{METAMORPHOSED MAFIC IGNEOUS ROCKS}

Metamorphosed mafic igneous rocks form a part of the basement assemblage in many of the areas visited. This section heading is apposite insofar as the bulk of the rocks examined are of mafic type, but some derivatives from intermediate igneous rocks are also included.

The main rock types include amphibolite and plagioclase amphibolite, hornblende-plagioclase gneiss (some diopside bearing), hornblende schist, and hornblendic schist with chlorite and epidote, or epidote and actinolite. The feldspar in the samples ranges mostly between andesine and labradorite, but may include oligoclase and, in a few samples, albite. Some of the rocks are garnetiferous. Metamorphism reaching grades appropriate to that of the almandine-amphibolite facies is indicated. Migmatites composed of amphibolite impregnated and veined with granitic material occur in several areas, such as in Wādi Banā, and amphibolite bands in migmatitic gneiss are also seen.

The original rock types involved in metamorphism appear to have included gabbro and diorite although some altered dolerites are recognized. Some of the chloritic and actinolitic schists of both W.A.P. and E.A.P. represent altered volcanic rocks, but in places this cannot be confirmed. Hornblende pyroxenite of Wādī Gharīsh, E.A.P., is considered to represent an ultramafic intrusion. Evidence for the occurrence of ultramafic derivatives has not been obtained elsewhere in the region, a fact which suggests that their distribution is very limited.

In the area southeast of Kirsh, diopside-plagioclase gneiss occurs in basement rocks consisting mainly of mafic and semipelitic schists, which have been affected by later granite invasion with the production of migmatitic rocks. The gneiss consists of pale-green ferroan diopside associated with abundant green hornblende, which is in equilibrium with the diopside and does not replace it. Plagioclase, between andesine and labradorite in composition, is twinned but unzoned and shows slight saussuritization. Sphene is the only accessory. The rock has clearly been metamorphosed in the almandine-amphibolite facies and has an assemblage indicating an original mafic igneous rockpossibly a banded gabbro (specimen A36).

Additional rocks considered to represent metamorphosed gabbro crop out in the Jibāl al Aswad area where they form part of a belt of metamorphic rocks in a dominantly granitic province. A specimen of these rocks (A225) is a coarse-grained type in which some ferromagnesian minerals have been converted to pale-green actinolite associated with green biotite. Plagioclase has been albitized. The high lime and alumina content indicated by the alteration products of the feldspar suggest original labradorite, whereas the large apatite crystals, altered ilmenite, and absence of quartz all suggest that the parent rock was a gabbro.

A metamorphic rock probably derived from a gabbroic or dioritic parent crops out north of $\mathrm{Ji}^{\top} \bar{a} \mathrm{r}$ in the Abyan district. This rock is a hornblende-plagioclase gneiss in which quartz and biotite are common. Feldspar is seriticized. Apatite, carbonate, granular epidote, and garnet occur in small quantities. Anhedral sphene is associated with the biotite.

Derivation from either a doleritic or gabbroic rock is indicated for a hornblende schist from Wādī Milḩ, southwest of Lawdar. The bulk of the rock consists of a fine mosaic of albitized plagioclase, with epidote green hornblende. The color index is high and quartz is a minor constitutent.

Field examination of a number of mafic schists, which contain actinolite, chlorite, and epidote and in which inclusions of rock fragments were discerned, led to the conclusion that the schists represent altered volcanic rocks. Some confirmation is afforded by examination of a specimen of fine-grained epidote-actinolite-hornblende schist from the west of the main ridge of Jabal ath Thaniyah. In this specimen, epidote occurs in granular form, and also forms composite porphyroblasts around which schistosity is deflected. These porphyroblasts appear to be pseudomorphs of either phenocrysts or amygdales. Interstitial quartz is present, and some of the plagioclase may be of sodic type. Carbonate minerals occur in bands and plates. The rock may represent a metamorphosed andesite. Similar rocks are recognized in Wādī Rufād (north of Jil'ah), E.A.P., and in a locality some 6 miles north of Yashbum, where hornblende-chlorite-epidote schists are interbanded with psammitic rocks.

Conspicuous microcline and biotite in hornblendeplagioclase schist from Wādi Banā, to the northwest of Al Mașāni', suggest potassic metasomatism associated with granitization. The high color index and mineral assemblage indicate an original mafic igneous rock. This schist forms part of a complex of mafic schists and gneiss and of pelitic schists, interbanded with felsic gneiss and cut by numerous feldspathic veins and dikes.

Polymetamorphism is indicated in porphyroblastic hornblende-chlorite-epidote schist from some 5 miles north of Yashbum. Hornblende in this rock appears to be breaking down under deformative stress.

In the upper reaches of Wādi Gharīsh, Eastern Protectorate, rock identified as hornblende pyroxenite (A232) is considered to represent an altered ultramafic intrusion. The dominant mineral in this unusual rock is a gray-green clinopyroxene-diopside or diopsidic augite-which occurs in crystals several millimeters 
long and shows deformation effects. In places the pyroxene is enclosed in euhedral hornblende. Conspicuous feldspar consists of relic sodic plagioclase enclosed in perthitic microcline. Red-brown biotite occurs sporadically in bent laths. Sphene occurs in irregular crystals. Certain outcrops of this rock show very large pyroxene crystals and may be pegmatitic. Hydrothermal alteration has affected the rock to a variable extent; pyroxenes may be altered to amphibole and talc, and from these serpentine has been produced, so that specimens from the same intrusive body are described as serpentinite with conspicuous areas of proxene in antigorite(?). The serpentine shows deformation effects and carbonate veining. Apart from hydrothermal alteration, it is difficult to assess the degree of metamorphism this rock has undergone. It is possible that it was origimally a peridotite, and in some of the serpentinous patches the outlines of olivine crystals can be seen. Under dynamothermal metamorphism the olivine may break down to tremolite (tremolitic hornblende) and talc, and at a high stage of metamorphism diopside may replace the amphibole. It is likely that the intrusion preceded the main stage of tectonism and regional metamorphism, and that the texture seen is of crystalloblastic type. The deformation shown may be attributed to a later period of dynamic metamorphism that affected a rock denuded of much of the superincumbent cover and thus at an effectively higher level in the crust.

\section{GRANITIC ROCKS}

Data from field, photogeological, and petrographical studies indicate that a number of phases of granitic invasion occurred in the Aden Protectorate. It is convenient to consider granitic rocks of various ages under one heading, and also logical, as they are considered to be genetically related in a granite series.

Before the granitic rocks are described, brief comment on the wider question of the origin of granite is pertinent, to provide a background to the interpretation offered and to clarify the meaning of the term "granitization" as used in the ensuing paragraphs.

Regarding the origin of various types of granite, the concept of zoning dependent on depth, and thus also dependent on temperature and pressure, is adhered to. This concept follows ideas advanced by Eskola (1933), by Read (1957), who stressed the factor of time as well as place, and by others. The weight of evidence appears to support the idea that granite emplacement involves movement of a partly liquid magma formed by differential fusion of mixed rock in the deep-seated basement assemblage. Such magma, which may be partly crystalline and perhaps more akin to mobilized migmatite, is squeezed upward by earth movements to levels removed from the zone of fusion.

Whatever the ultimate origin of the granitic bodies exposed in the Protectorate may have been, it is clear that some have gradational contacts with surrounding rocks and that others are clearly crosscutting and have distinct thermal aureoles. In the first group, granitization by metasomatism is recognized insofar as this refers to an exchange of material between the main granitic body and the country rock. It is probable that the introduction of ions through aqueous and other fluids derived from crystallizing magma is here an important process. This type of granitization, with which sodium and potassium metasomatism and injection phenomena are associated, is likely to be most strongly developed where granitic material is emplaced at the height of tectonic activity, during periods of regional metamorphism. Activity is then stimulated by high temperature, pressure, and consequent mobility. The result of granitization is to produce rocks which, in respect to minerals or texture, are more like granite than they were before. The term "granitization," as here used, does not necessarily imply production of completely granitic rocks.

Peralkaline intrusive granite occurs in two localities, from one of which evidence for a Late Cretaceous to Tertiary age was obtained. These rocks are referred to as posttectonic alkaline granite.

The differentiation of granites of various types has not been possible in all areas and is the more difficult because granitic invasion of two or more periods may have occurred successively in the same general area. Field observations show that emplacements may be composite.

\section{SYNTECTONIC GRANITE}

Field reconnaissance and photogeological study indicate that syntectonic granite is areally the most extensive of the Protectorate granites.

Four main types of granite are recognized in the Aden Protectorate. The oldest, syntectonic granite, is associated with extensive granitization of surrounding rocks and with zones of migmatization (fig. 9), and is considered to have invaded rocks of the Aden Metamorphic Group broadly synchronously with the culmination of the main period of regional metamorphism, although certain phases of the invasion may have been prolonged beyond this time. The syntectonic granite does not appear to result entirely from the conversion in situ of existing rock, but rather to represent a partially mobilized migma-magma mix. The criteria by which this type of granite is recognized are given later in this report. 


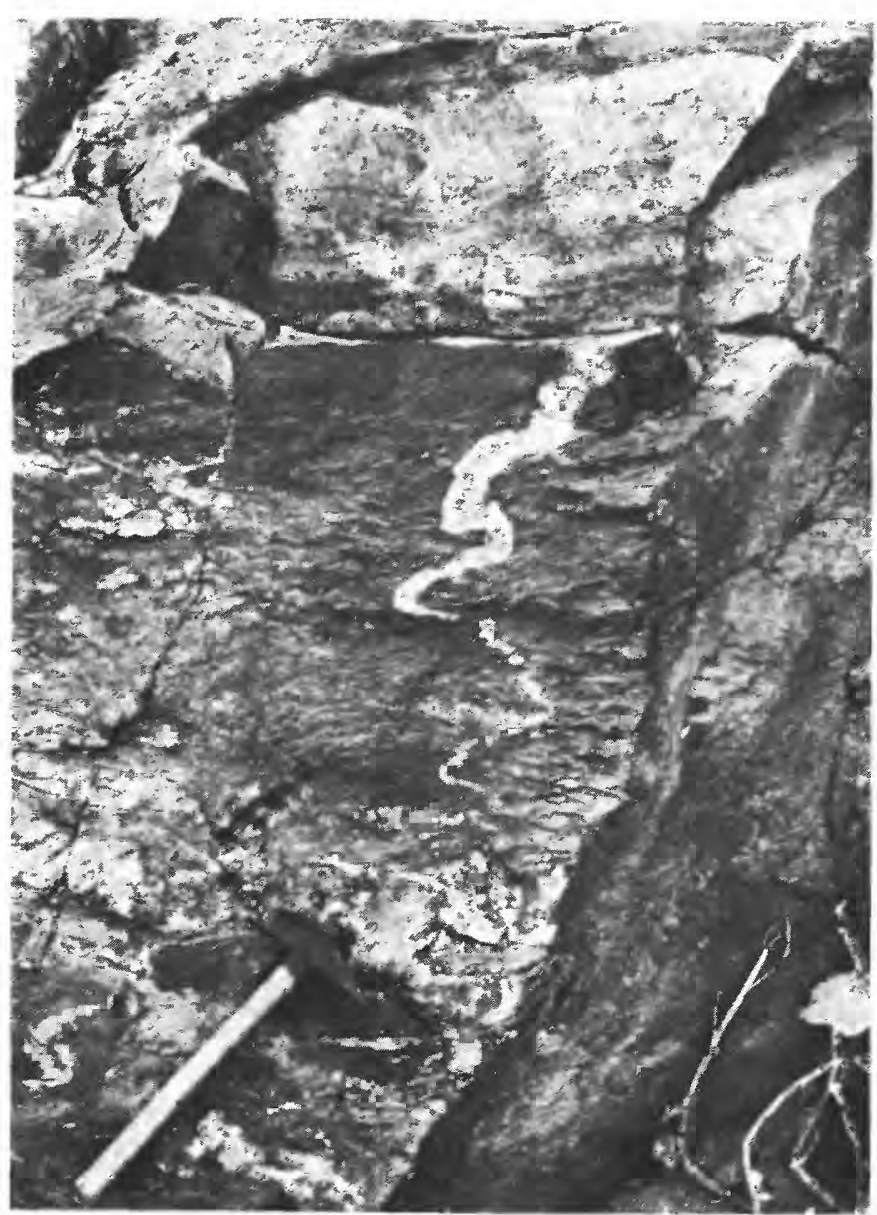

Figure 9.-Biotite schist and migmatite, 2 miles west of Sa'ĩd.

A second type of granite is designated "intertectonic." Granites of this class are nonfoliate intrusive rocks without the extensive zones of metasomatism that typify syntectonic granites. Their emplacement subsequent to the period of regional metamorphism which resulted in the Aden Metamorphic Group is shown by inclusions of metamorphic rock and older dioritic rock, but well-marked shearing and deformation effects indicate that they predated a phase of stress metamorphism.

A third type is represented by posttectonic calcalkaline granites which show no deformation; some of these show discrete and sharp aureoles of contact metamorphism and they are commonly of relatively restricted outcrop area, roughly circular in plan. An early Paleozoic age is indicated by several age determinations.

Criteria by which syntectonic granites are recognized in the field, some of which are applicable in photogeological interpretation, include the following: Generally concordant and gradational relations with surrounding rock; no evidence that magma disturbed or displaced contact wallrock; absence of distinct thermal aureoles; the presence of feldspar porphyroblasts and bands in country rock, which are larger and more abundant toward the main granite body and progressively diminish toward peripheral unaffected country rock; xenoliths in the granitic body are oriented parallel to the country rock; the peripheral parts of a large granite mass are commonly gneissose and may show flow effects, and augen and flaser textures may be developed; the foliation of granitized country rock is parallel to that of invasive gneissose granite.

Criteria recognizable in petrographic examination include the following: Variety in size and form of mineral grains; presence of abnormally large crystals such as feldspar porphyroblasts; clear crystals in a mainly turbid rock; extensive albitization and abundant myrmekite and myrmikitic intergrowth; presence of much epidote; pseudobrecciate structure.

Many of the features noted above indicate granitization; others result from the emplacement of granitic material synchronously with stress accompanying regional metamorphism. The field examination of a number of syntectonic granites leads to the suggestion that these are partly of subautochthonous type and partly transitional between subautochthonous and cross cutting granite. Thus they show feldspathized peripheral areas and migmatitic and gneissic zones, as well as homogeneous magmatic areas.

Features typical of the syntectonic granite of the Protectorate were illustrated in a traverse southeastward along the newly made track from $\mathrm{Al} \mathrm{Kirsh} \mathrm{to}$ Lahi, which runs to the west of and parallel to the upper Wādì al Kayfī. The progressive alteration of country rock about a central granite area is demonstrated over a distance of about 5 miles (figs. 10, 11). At the northern end of the traverse pelitic and mafic schists are sparsely invaded by thin bands of granitic material, accompanied by thin feldspathic bands and stringers. About 4 miles from the central granite is a belt of migmatite consisting of coarse-grained granitic material injected into hornblende schist. This is succeeded by hornblende-plagioclase gneiss cut by bands of feldspathic and granitic material some 6 inches thick oriented parallel to the foliation of the gneiss. The feldspathic bands are ptygmatically folded. There follows a zone of biotite schist with profuse feldspar porphyroblasts, in which are bands of gneissose granite some inches thick. A more extensive zone of migmatite precedes foliated granite containing elongate patches of schist, which are feldspathized and cut by numerous feldspar bands. The schist shows diffuse borders; it also occurs as impersistent thin streaks in the granite. The central granite is of calc-alkaline type and shows shearing and granulation. The strike of foliation planes in less altered country rock, migmatite, and 
foliated granite is uniform at about N. $70^{\circ} \mathrm{E}$. In this area, as elsewhere, dikes of feldspar-quartz-mica pegmatites are associated with the granite. Such dikes appear to be much restricted in areas of later granites.

A further demonstration of the characteristics of syntectonic granitic invasion, accompanied by granitization, was afforded by a traverse along an unnamed north-south trending wadi which reaches the coast some 10 miles west of 'Irqah. Here is shown a gradational passage from central nonfoliate biotite granite, through peripheral zones of gneissic biotite granite with feldspar augen reaching $3 / 4$-inch diameter, into an outer zone where foliated granite is banded with biotite and muscovite schist. Patches of migmatitic rock occur. Bands of gneissose granite continue to appear in the metamorphic country rock for several miles from the focal point of granitic invasion. For a distance of some 6 miles from the central granite, feldspathization of varying intensity affects surrounding rocks, which include pelitic, mafic, and psammitic schists. In the more central zone are feldspathic bands and stringers; these give way outward to lenses and patches of feldspar, and finally to feldspar porphyroblasts in schistose rock. The feldspar bands generally are oriented parallel to schistosity planes of the country rock and are contorted and ptygmatically folded concordantly with the country rock, conditions indicating invasion synchronously with regional metamorphism when all rocks were plastically mobilized. Pegmatitic bodies, dikes, and lenses are abundant in the central area and in several places consist almost entirely of

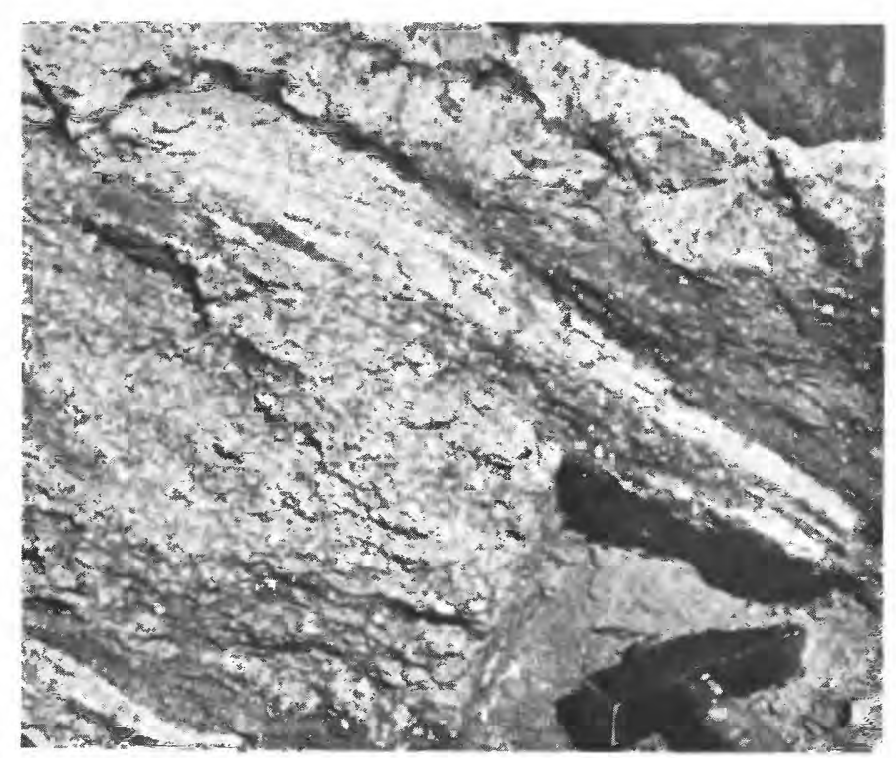

FIgUnE 10.-Feldspathized biotite schist, J miles southeast of Al Kirsh. muscovite. Pink garnet occurs in the feldspar of many of these pegmatites. Quartz veins and stringers are associated with pegmatites but, unlike these, also occur in peripheral metamorphic rocks.

The history of granite formation in this area is interpreted as a migma-magma invasion toward the end of a major period of regional metamorphism, the mobilized material being displaced upward above the zone of origin, but at a relatively low level. Metamorphosed sedimentary rocks were partly granitized. Close to the focal point of the invasion some migmatization of country rock occurred. Bands of crystalline limestone in the area remained unaffected by granitization. In the waning phases of granitic invasion, pegmatites were injected in the central zone while quartz veins formed in zones more remote from the focal point of invasion.

Foliated syntectonic granite occurs in Wādì Banā a few miles northwest of Al Maşāni‘. The rock crops out mainly in bands some 3 feet thick in an assemblage of pelitic schists and hornblende-plagioclase gneiss. Feldspathization is well marked in this area in the form of porphyroblasts in the schists, and numerous feldspathic lenses and bands, some of which reach a thickness of 30 feet. Quartz veins are few and small. A specimen of foliated granite from this locality (A62) is a quartzofeldspathic-biotite gneiss of granitic composition, in which porphyroblasts of pink orthoclase up to $1 \mathrm{~cm}$ long commonly contain relic patches of microcline. Quartz shows strain effects. Myrmekite is fairly conspicuous. From laboratory study it is not possible to determine whether the rock represents a deformed and recrystallized granite or a granitized sedimentary rock.

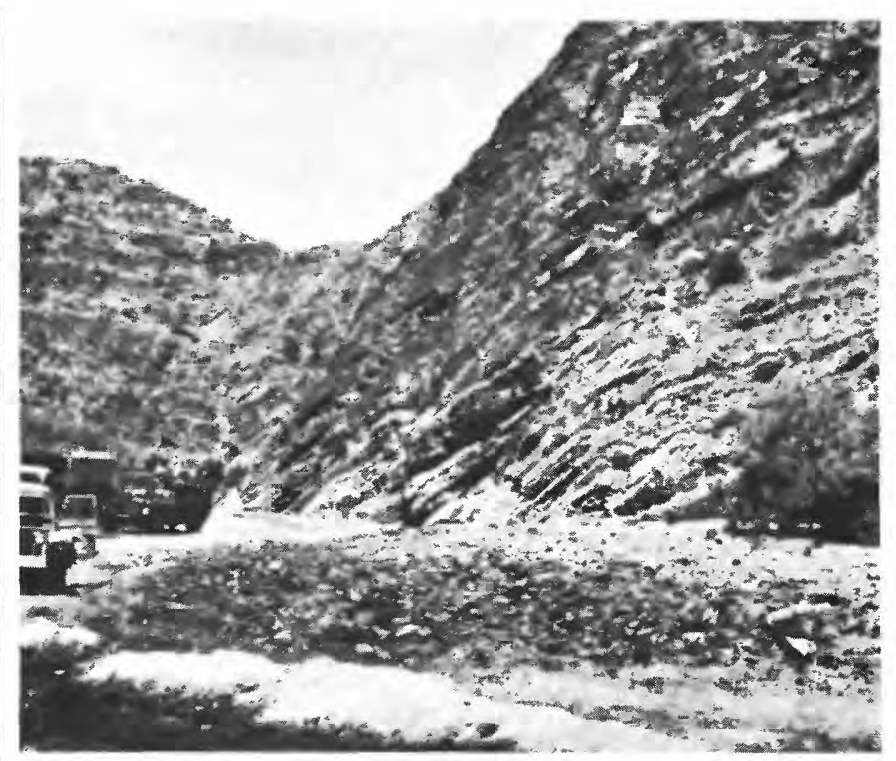

FIGURE 11.-Hornblende schist impreguated with granitic material, Wàdì al Kayfì. 
However, large potassium feldspars, dark quartz, and a pseudobrecciated appearance indicate the latter, and this is supported by field observations.

A traverse along Wādì Raybān and Wādì Milḩ to Al Mājil, 8 miles southwest of Lawdar, showed invasion of syntectonic granite into metamorphic rocks that were mainly hornblende-plagioclase gneiss and pelitic schist, with metacalcareous and quartzitic representatives. The foliated granite occurs as numerous bands some of which are as thin as 6 inches. Intense epidotization affects adjoining rocks. Feldspathic bands and stringers are numerous; some grade into granitic rock. Quartzites show abundant porphyroblasts of white feldspar. Pegmatites are well developed and some contain garnet. A notable pegmatite dike some 210 feet thick extends more than $1 \frac{1}{1} / 2$ miles along Wādī Milh; its emplacement seems to be related to faults along the wadi. A specimen of gneissic granite from this area (A71) shows several features indicative of granitization. These include a pseudobrecciated appearance (large areas of quartz or microcline surrounded by smaller areas of the same material showing no apparent granulation); abundant myrmekite; conspicuous microcline porphyroblasts; and erratic variation in grain size.

Protoclastic effects are recognized in certain granitic rocks of this area; the rocks are considered to have been partly crystallized and to have contained diminished interstitial liquid, which flowed under differential stress. The crystals were ground together and deformed. Evidence of granulation is accompanied by relics of larger crystals.

The granite of the Mudiyah area is largely of posttectonic type; but on the eastern flank of this intrusive granite is foliated granite in bands some 6 feet thick, alternating with hornblende and biotite schists and associated with feldspathic bands. In some localities plugs of later red intrusive granite appear to cut this syntectonic granite.

Farther to the east of Mūdiyah, in the Nūsah locality, the effects of syntectonic invasion are shown by the occurrence of biotite schists heavily studded with feldspar porphyroblasts. Some 3 miles northeast of Nūsah, migmatites have resulted from the injection of granitic material into hornblende schists. Mafic components show marginal enrichment in biotite and are finer grained toward the granitic layers.

Traverses from the central part of the granite in the Şa'îd area outward to the eastern, western, and northeastern borders indicate that this is a composite body of later intrusive granite emplaced in older syntectonic rock. The intrusive rock is homogeneous, nonfoliate, and intensely jointed. The peripheral syntectonic granite is foliated and crops out as bands in feldspathized and granitized country rock; further- more, this granitic rock is associated with numerous pegmatite dikes which are apparently absent from the central granite. Aerial photographs show a distinctive contrast in weathering habit between resistant peripheral syntectonic granite and the much reduced intrusive type.

At Nişāb, as in the Şa id area, there appear to be two types of granitic rock, namely a foliated syntectonic granite which is generally peripheral to a nonfoliate intrusive variety of later date. About 12 miles south of Nişāb, syntectonic granite forms a gradational contact with schistose country rock. The bedded character of the granite, which is clearly seen on aerial photographs (fig. 12), may be due to relic bedding expressed by differential weathering; if so, it supports the view that much of this foliated rock results from granitization. A specimen of garnetiferous granite gneiss from the south of Nişāb (A147) consists mainly of orthoclase, sodic oligoclase, quartz, brown biotite, and green amphibole. The high feldspar content and the general appearance of the rock indicate a syntectonic type.

Granite of the Jibāl an Nisiyin block, the center of which lies some 30 miles northwest of Nişāb, is mainly of nonfoliate later intrusive type; but at Al Husşān to the southeast of the block and at Wādi Mațārif on the northeast border, gneissic biotite granite with feldspar augen is exposed. This is interbanded with biotite-chlorite schists and metacalcareous rocks. The main granite block is intersected by a northwesttrending belt of metamorphic rocks in which some quartzo-feldspathic gneisses appear to have been formed by granitization. Foliated granitic rocks of this belt show gradational contacts with feldspathized schist or are in contact with quartizitic rocks resistant to granitizing processes. Specimen A181, from the northwestern end of the metamorphic belt, is quartzofeldspathic gneiss showing pronounced biotitic banding. Altered microcline occurs in phenocrysts as much as $1 \mathrm{~cm}$ in diameter, and also interstitially. Calcic oligoclase may also occur as phenocrysts showing deformation. Myrmekite is common, and granular epidote is present as an accessory mineral. Petrographic study suggests that the rock represents a granitized metasedimentary rock which suffered subsequent deformation. The alternative possibility of a deformed adamellite is considered less likely.

In the Jibāl al Aswad range, flanking the plain to the north-northeast of Mayfa'ah (Al Wāhidī), granitic rocks are bordered to the north by a belt of metamorphic rocks. The eastern part of this range was not visited, but aerial photographs show an apparently sharp contact between homogeneous granite and metamorphic rocks. 


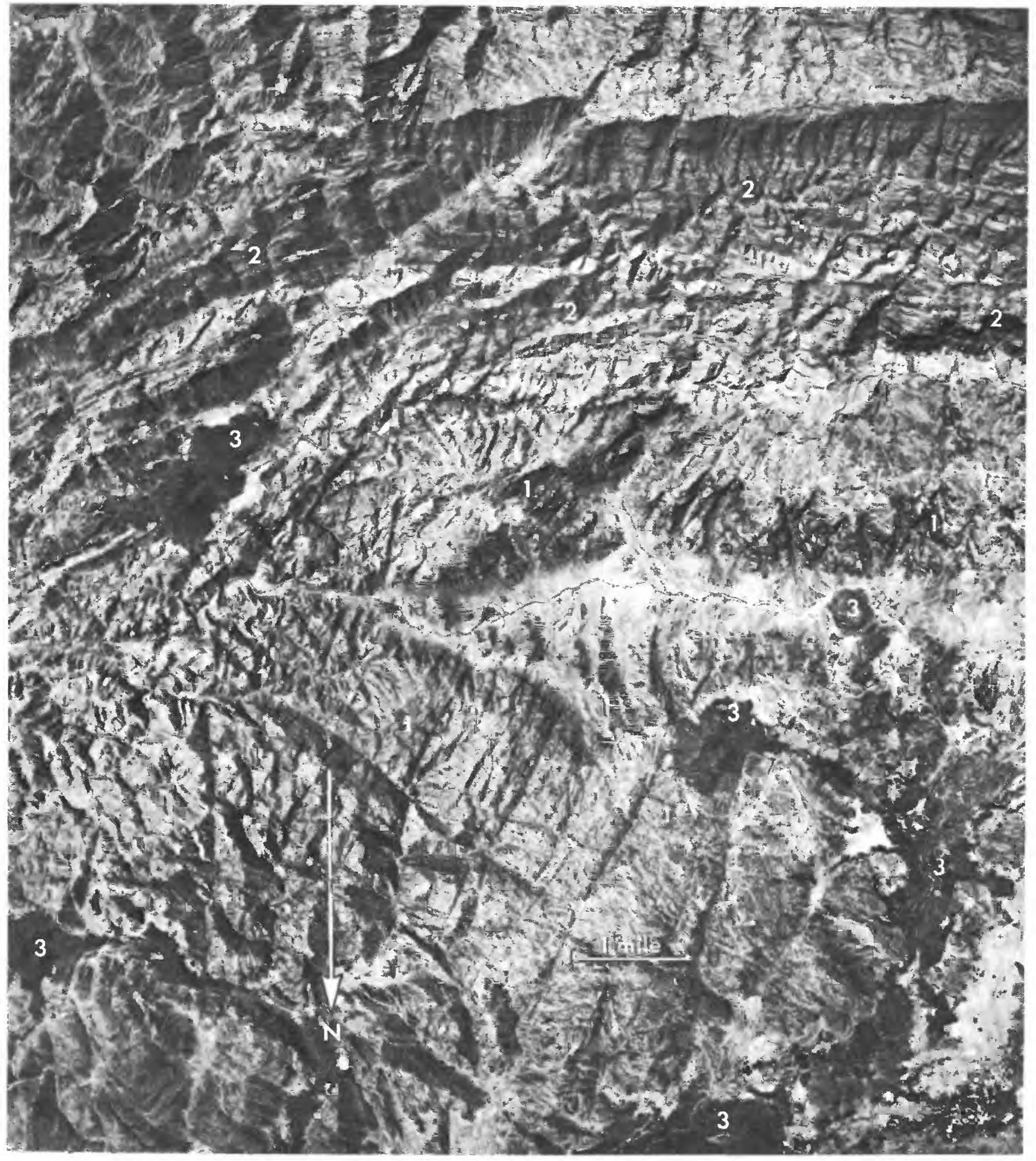

Figre 12. Syntectonic granite, 1.5 miles south of Xisāb. Foliate sranite (1) shows a "beddec" appearance indicating selective and incomplete granitization. To the south of the grant area, pelitic and mafic schists are seen (2). Yolcanic rents and basalt flows of the Aden Volcanic Series occur (3). Royal Air Force photograph. Crown copyright reserved. 
In the western part of the range, granitic rocks form a gradational contact with metamorphic rocks, and zones of mixed or granitized rocks are present. A traverse across the granitic area into metamorphic rocks revealed a degree of feldspathization unexcelled in any other area visited. Foliated biotite granite grades into coarse feldspar-quartz rock in which a faint foliation is defined by sparse laminae of biotite. Feldspar crystals in this rock may reach $2 \frac{1}{2}$ inches in diameter. As inclusions within the granite and interbanded with it are quartz-biotite-chlorite schists and biotite schists, thickly studded with feldspar porphyroblasts for several inches from the granite margin (figs. 13, 14) and showing lesser concentrations of these porphyroblasts form many yardsfrom the junction zones. Impersistent quartz veining was noted, but pegmatites were not seen. The dominant feature of this area is feldspathization. This, with other field observations, indicates invasion of chemically mobile granitic material under favorable conditions for metasomatism such as would obtain were granitic invasion contemproaneous with regional metamorphism. It seems that the western part of the Aswad range is largely syntectonic granite, whereas in the east the granite is probably a later intrusive type.

Syntectonic granite, associated with zones of feldspathization and commonly with migmatitic areas, was also observed near 'Awābil; near Tor al Baha; in Wădi Ahwar; in the Al Khabr area; south of Khawrah; and in the Bayhān area. In the Bayhān area, granite representative of the syntectonic phase appears to be restricted in occurrence, and here also the presence of granites of intertectonic and posttectonic periods, together with paragneiss, makes separation particularly complicated.

In summary, focal points of syntectonic granite invasion are recognized in many areas of the Western Protectorate. Invasive material seems to have been partly of magmatic character, and partly of a composite migma-magma type; it is represented by granites of calc-alkaline composition, and less commonly by adamellites. These are foliated rocks, at least in the zones peripheral to foci of invasion. The granitic rocks are associated with extensive zones of feldspathization in many places with migmatitic areas of rather limited extent. In a number of places the metamorphic grade of surrounding rocks is affected for several miles from the granite center. Pegmatites occur as a characteristic feature, and in these muscovite (as books) and garnet-bearing feldspars are well developed. No pneumatolytic deposits, typically connected with many intrusive granites, have been recorded. Evidence for granitization rests mainly on general field relations, but is supported by some petro-

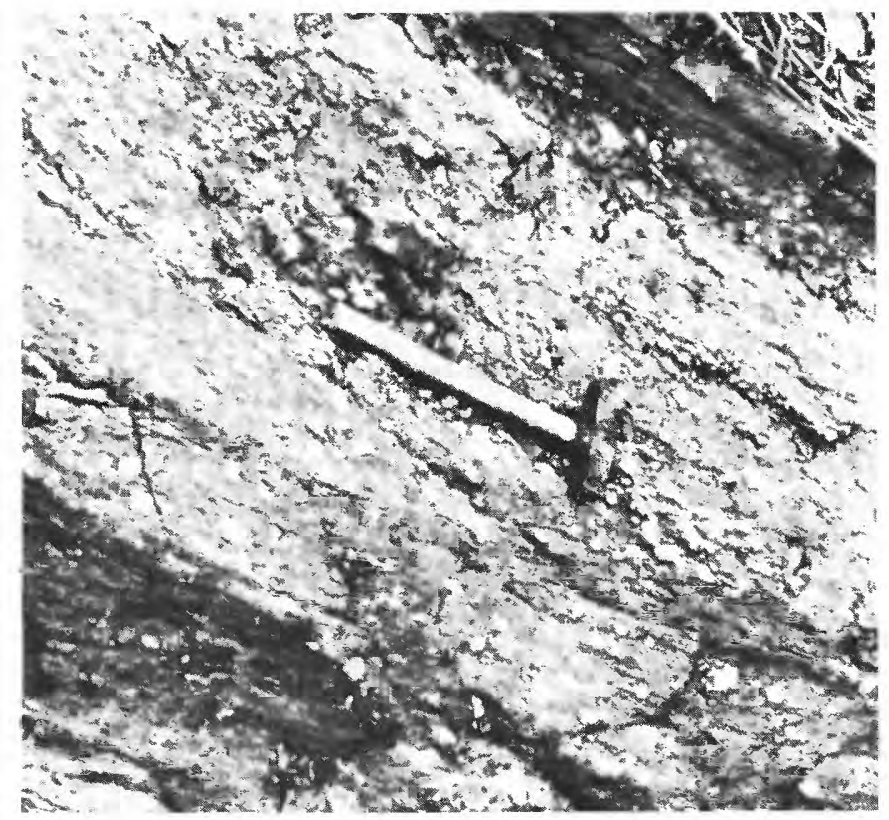

Figure 13.-Feldspar porphyroblasts in biotite-chlorite schist, Jibūl al Aswad area.

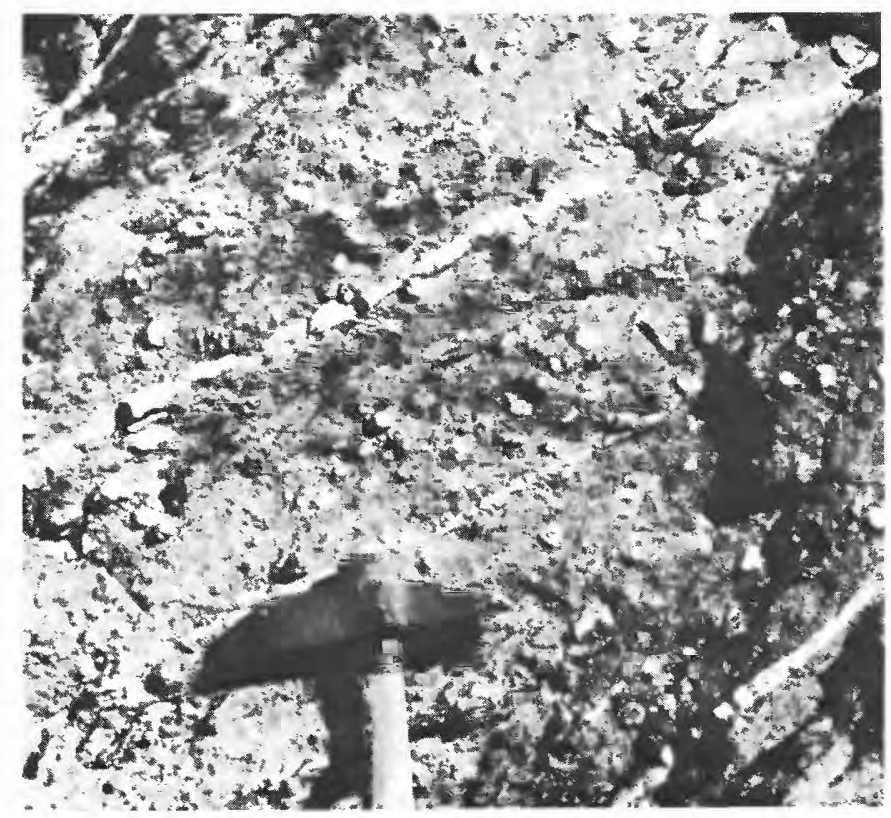

Figre 14.-Feldspar porphrroblasts and thin quartz veins in biotite schist, west-central Jibāl al Aswad range.

graphical study. Several specimens examined show protoclastic effects pointing to invasion during crustal stress. Recrystallization noted in several specimens indicates phases of renewal of stress within the main episode of regional metamorphism. Deformation of cataclastic type is attributed to a later period of mainly dynamic metamorphism. 


\section{INTERTECTONIC GRANITE}

Rocks assigned to the intertectonic class are nonfoliate granites without extensive zones of metasomatism or migmatization. They are further distinguished from syntectonic granites by the absence or very restricted development of associated pegmatites.

The later origin of intertectonic granites is indicated by the fact that in the Mukayrās area these show inclusions of dioritic rock which is clearly differentiated, by the absence of any considerable degree of regional metamorphism, from the mafic components of the Aden Metamorphic Group. Evidence that syntectonic granite invasion was roughly coeval with metamorphism of this group has been noted. It is therefore considered that the dioritic rock and associated intertectonic granite postdated syntectonic granite. The intertectonic granites are characterized by cataclastic effects, deformation, and shearing, which indicate emplacement prior to a period of dynamic metamorphism; by this they are distinguished from posttectonic granites.

Rocks of this group include calc-alkaline hornblende and biotite granites, granodiorites, and syenites. They are exposed in the Mukayrās-Khawrah region, and possibly also near Jabal ath 'Thaniyah in the Ramlat as Sab'atayn.

Granite exposed in the Mukayrās area is typically a nonfoliate pink feldspar-hornblende-bearing rock, in which the amount of biotite is variable but generally small. Epidote is commion as patches and bands in the granite, and it lines shear planes. The granite is well jointed. A specimen from 3 miles northeast of Mukayrās shows calc-alkaline granite with large phenocrysts of perthite and sodic plagioclase in a groundmass of albite, oligoclase, quartz, fawn-colored biotite, and hornblende. Plagioclase is partly epidotized. In the same general area occurs hornblende adamellite in which quartz plates are full of shatter cracks. Traverses southward from the central area of the granite in the Mukayrās area suggest a zoning from hornblende granite through granodiorite and quartz diorite to hornblende diorite. The impression gained in the field was that the center of the granite is more biotitic than hornblendic.

The relation of the granitic rock to dioritic intrusives suggest that the latter predated the granite by a short interval, and contamination by interaction with this earlier more mafic rock resulted in hybridization. Evidence of hybridization is seen in a specimen (A105) from some 5 miles northeast of Mukayrãs. This is a hornblende microgranite containing perthitic phenocrysts and prisms of green hornblende, many of which are zoned, with a core of blue-green amphibole surrounded by darker hornblende. Darker patches in the rock contain more abundant amphibole, and in these perthite is absent. In a specimen (A110) from 'Aryab, $2 \frac{1}{2}$ miles east of Mukayrās, calc-alkaline granite passes gradually into a quartz diorite.

In the Khawrah district, nonfoliate hornblende granite contains inclusions of dioritic rock of the same type as seen at Mukayrās, and also contains inclusions of older mafic metamorphic rock. A noteworthy feature of the Khawrah district is the presence of a number of reduced arenalike areas of subcircular shape. These were first noted on aerial photographs. One of the arenas, about 11 miles south-southwest of Khawrah, was visited, and it proved to consist of syenite surrounded by more resistant dioritic rocks. The diameter of this arena is about $1 \frac{1}{2}$ miles. The outer surrounding rocks are mainly hornblende-plagioclase gneisses which pass inward to nongneissose quartz diorite and diorite, into which the syenite was intruded. It seems probable that the nonfoliate diorite was also intruded through the older gneisses and is equivalent to the diorite of Mukayrās.

Altered granitic rocks from isolated small hills some 4 miles west-southwest of the northern ridge of Jabal ath Thaniyah may perhaps represent intertectonic rocks. Specimens show granodioritic types in which quartz shows strain effects. Bent actinolite laths show a parallel arrangement that suggests incipient schistosity.

\section{POSTTECTONIC GRANITE}

Granites of the posttectonic class occur typically in fairly restricted outcrops, generally subcircular in plan, and they display evident crosscutting relations with surrounding rocks. Contact zones of thermal metamorphism are narrow and distinct. Lineation, if present, is such as may arise as a primary flow structure during consolidation of a magma. In some places, as at Nișāb and 12 miles southeast of Bayhān, distortion of basement-rock strike due to intrusion of granite is seen. Posttectonic granites show strong, commonly intense, jointing. Their weathering characteristics contrast with syntectonic granite and associated granitized rock, which in several districts, such as in the Sa'id area, form upstanding margins to the much reduced later intrusive rock. Some of these features can be recognized on aerial photographs, but because these granites in certain areas have been emplaced in older granite, some of the characteristics noted may be lacking.

Most of the posttectonic granites are of calc-alkaline type. Determinations made for a number of these indicate an apparently early Paleozoic age. Alkaline granites of much restricted occurrence are probably of Tertiary age. 
CAIC-ALKALINE GHANITE

In the Lawdar-Mūdiyah district occur two varieties of posttectonic granite-a medium-grained gray rock and a finer grained red granite whose coloration is due to altered iron-bearing and limonitic stringers. These rocks consist of microcline, oligoclase, and quartz, accompanied by biotite and muscovite. In the granite 4 miles northeast of Lawdar, inclusions of biotite schist and hornblende schist reach areal dimensions of 90 by 30 feet and show sharp contact with enclosing granite. Pegmatites are sparsely distributed and of small extent. Quartz veins are numerous and appear to be characteristic of posttectonic granite. Weathering to exfoliated domes and kopjes and concentric (onion-skin) weathering of boulders is well marked; this also seems to be typical of later intrusive granites (fig. 15).

Granite similar in composition and texture to the granite in the Mūdiyah district underlies the sandy plain of Jawl as Salab to the southeast of Nişāb and constitutes most of the Jibāl an Nisiyin block northwest of Nişāb.

In the Baybann area, notably to the south and northwest of the town, aerial photographs show a number of subcircular depressed areas of light tone and without lineations, surrounded by topographically higher metamorphic rocks. By analogy with similar features visited in the field, these are thought to be intrusions of posttectonic granite. They are clearly distinguishable from granitized rock, which shows a foliation parallel with adjoining metamorphic rocks.

Some 10 miles northeast of Bayb̧ann, in the Wādī al Jif'iyah area, is a granite containing conspicuous biotite, microcline perthite, and oligoclase (A201). The relations with adjoining schist suggest intrusion. The rock

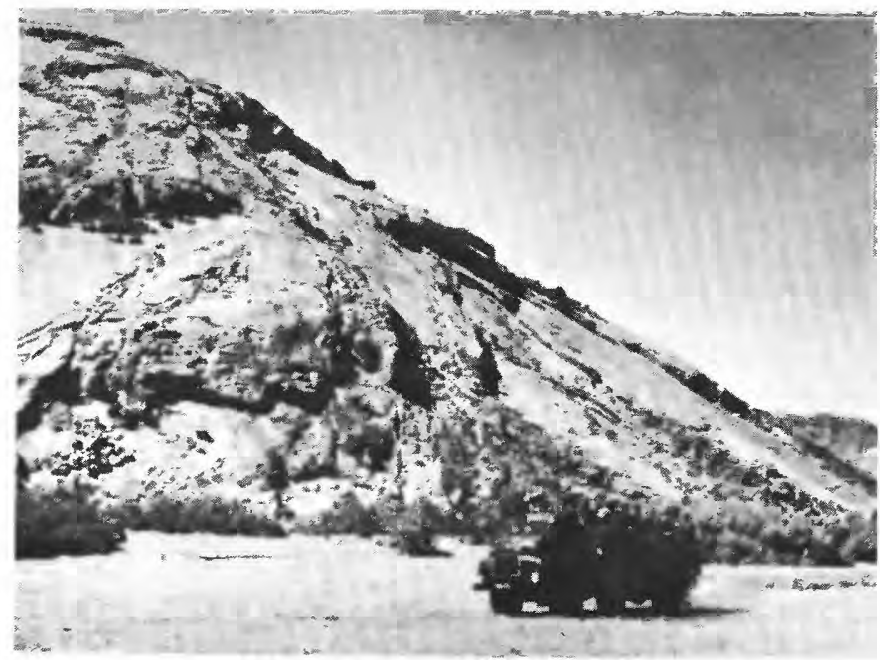

Figure 15. - Intrusive granite, 6 miles south-southwest of Nişāb. $221-6710-67-3$ shows a faint lineation due to parallel orientation of biotite flakes, but is not gneissose. Age determinations indicate an apparent age of $552 \mathrm{~m} . \mathrm{y}$. (million years). In the same general area gneissic syntectonic granite is recognized, into which the dated granite appears to be intrusive.

A clear example of posttectonic granite is seen in the Burūm area of E.A.P., where a medium-grained gray granite is cut by dikes or bands of finer grained red granite. Interlacing quartz veins are more commonly associated with the later red fraction. Inclusions in the granite consist mainly of altered hornblendic rock. A specimen of this well-jointed granite (A257) shows large areas of microcline perthite, zoned plagioclase, and quartz. Partly chloritized fawn-colored biotite is conspicuous. Accessory minerals include sphene, zircon, apatite, and iron oxide minerals. To the south and east the granite is in contact with older volcanic rocks of mainly andesitic type (fig. 16). The contact is sharp, and where examined a thermal aureole about 12 to 18 inches wide is developed, the contact rock being an andesitic hornfels with porphyroblastic hornblende. For about 100 yards from the contact leucocratic granite and microgranite dikes cut the volcanic rocks. The dikes are about $3-6$ inches wide. Age determination on biotite from this granite gives an apparent age of $515 \mathrm{~m} . \mathrm{y}$.

At Jabal Zulm ash Shaybah, about 21/2 miles northwest of Ra's Husayşah, E.A.P., a granitic cupola intrudes older volcanic rocks, with the production of a hornfelsed contact zone. In Wādī al Ghabar, E.A.P., some 3 miles northwest of Mudhaniyah-Al Ghabar wadi junction, granite also intrudes older volcanic rocks. In this outcrop, as at Mūdiyah and Burūm, a finer grained red feldspar variety is associated with a coarser gray variety. No deformation effects have been noted in thin section (specimen A249). Dating of this rock gives an apparent age of 652 m.y.

Apart from those just mentioned, posttectonic granites of calc-alkaline type occur at Sa 'id (previously noted in connection with syntectonic granite) and in Wādi al Kayfī, 11 miles south-southwest of Al Musaymīr. The Wãdì al Kayfĩ rock provides a further example of later granite apparently intrusive into earlier syntectonic granite. A specimen of the Wādi al Kayfĩ granite gives an apparent age of $480 \mathrm{~m} . \mathrm{y}$.

\section{ALKALINE GRANITE}

Specimens proving to be alkaline granite were obtained from the northern part of the granite at Jabal al Munif in the Al 'Anad area. It is not known whether all the granite near Jabal al Munif is of alkaline type; variations in composition and texture observed in the field suggest that some may not be. Calc-alkaline granite is 


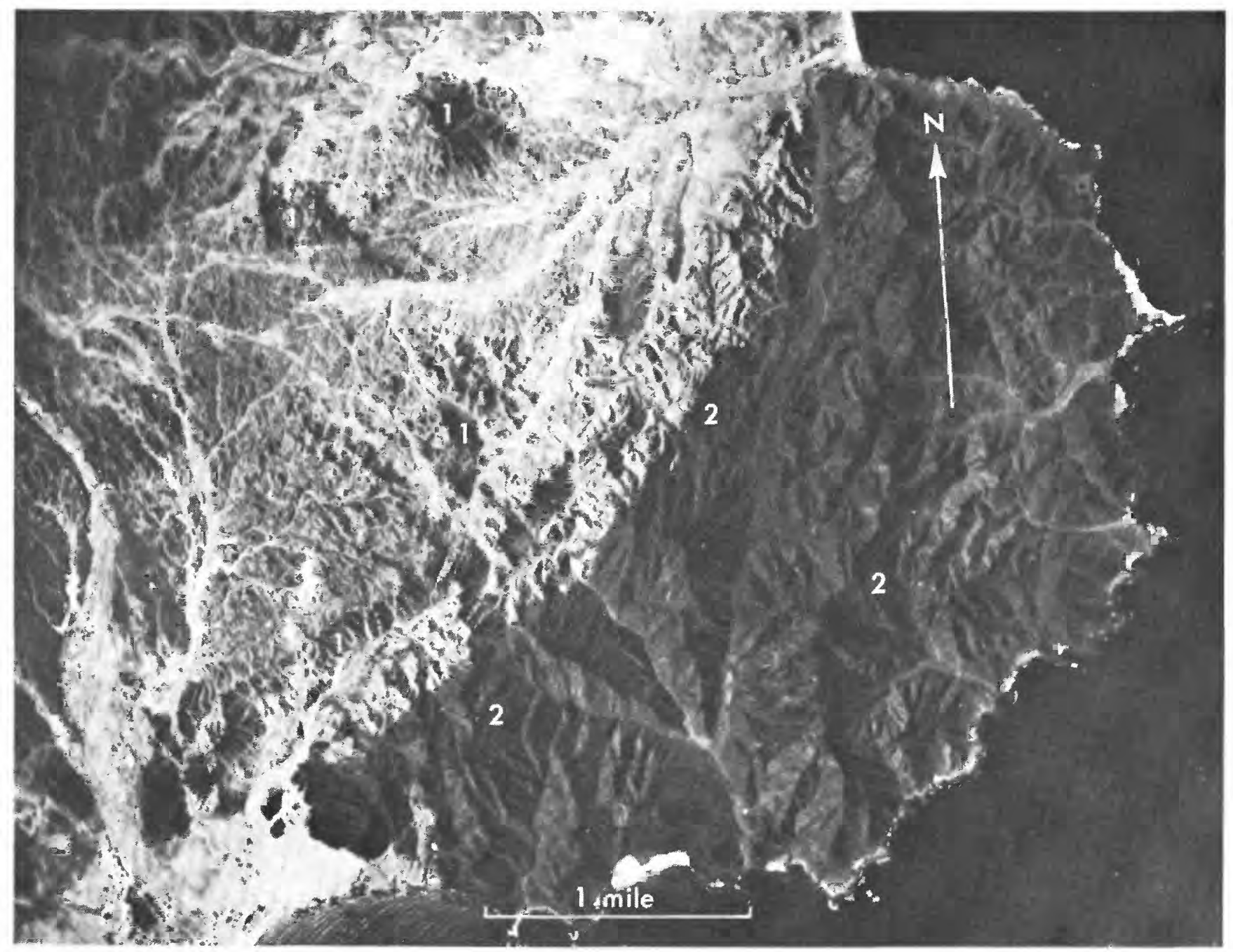

Frgure 16.-Intrusive granite of Ra's Burūm, E.A.P. The sharp contact between the posttectonic granite (1) and older volcanic rock (2) is clearly shown. Royal Air Force photograph. Crown conyright reserved.

known to occur 2 miles northwest of the site of the alkaline granite specimen. The latter (A17) contains aegirine, zoned and margined by acmite, and sodic amphibole showing intense pleochroism from deep blue green to greenish yellow. Feldspar consists of albitized plagioclase partly replaced by potassium feldspar, together with large areas of perthitic potassium feldspar, also altered. Quartz is abundant. From the same area, alkali-microgranite with sodic amphibole was obtained.

Alkaline granite also occurs about 2 miles northnortheast of Mukayrās. A specimen of this (A101) shows riebeckite in a single-feldspar (perthitic othoclase) rock. The extent of this alkali granite in an area of predominantly calc-alkaline type was not established. It is likely to be small.

The alkaline granite of Jabal al Munif shows relations with Cretaceous sedimentary and volcanic rocks of the Aden Trap Series which strongly suggest intrusion through these rocks. It is considered that part, if not all, of the Jabal al Munif granite mass was erupted later than contiguous basaltic lavas, and is probably of later Tertiary age. It is tempting to opine that the only other representative of alkaline granite recorded in the Protectorate, near Mukayrās, is of the same age. There is no field evidence to support this assumption. However, on the evidence from Jabal al Munif and on general considerations of petrogenesis, both the alkaline granites are tentatively regarded as younger than the calc-alkaline posttectonic granites.

It is of interest that Geukens (1960) described intrusive Tertiary granites in Yemen; and Karrenberg (1959) mentioned alkalic and transitional types in Yemen, which he also dated as Tertiary.

The alkaline granite may possibly be the product of differentiation of basaltic magma, as these small and conceivably shallow budies at Jabal al Munif, as in 
Yemen, are associated with volcanic rocks that comprise a large proportion of mafic lavas. These latest granites may thus be of different origin from the majority of Aden granites.

\section{MAFIC INTRUSIVES}

\section{INTERTECTONIC MAFIC INTRUSIONS}

A group of intermediate to mafic rocks show a moderate degree of metamorphism, mainly of dynamic type, resulting in shearing, deformation, and cataclastic effects. Their metamorphic state is not compatible with their having undergone the regional metamorphism responsible for the conversion of intrusive mafic igneous rocks to reconstituted gneisses and schists of the Aden Metamorphic Group. Thus they are considered to have been emplaced between the main period of regional metamorphism and a later period of dynamic metamorphism which also affected rocks of Wādi al Ghabar, E.A.P., regarded as latest Precambrian in age. The intertectonic mafic intrusives are generally nonfoliate rocks. They appear to have predated, by a short interval, the intertectonic granites; and by interaction with the latter, contamination and hybridization resulted. This is mentioned in the section "Intertectonic granite."

Rocks of this group are recognized mainly in an area approximately bounded to the east by a line from a point 5 miles west of Nişāb extending southwestward along Wādì Durā and continuing with some southeastward displacement along the escarpment of the Kawr al 'Awädhil to the locality of Mukayrās. To the west, the Yemen boundary limits observed exposures. This area includes the towns of Mukayrās and Khawrah. Intertectonic rocks are here associated with metamorphic rocks of the Aden Metamorphic Group, and in the Khawrah district, with limited exposures of syntectonic granite.

More limited occurrences of these rocks were recognized in the Wādi al Jif'iyah area, 12 miles northeast of Bayhan, and in Wādi Milh, 14 miles southwest of Lawdar.

The rocks are mainly of dioritic and gabbroic type; quartz diorite, or tonalite, is also recorded.

The relation of intertectonic rocks to older rocks of the Aden Metamorphic Group is illustrated in a number of exposures in the Mukayrās pass. Rocks exposed on the Mukayrās plateau consist of dioritic and granitic plutonic intrusives cut by numerous dikes; toward the southern edge of the plateau dioritic rocks contain

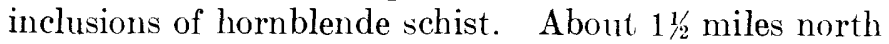
of the pass head is a belt of hornblende-plagioclase gneiss interbanded with hornblende schist, and at the top of the pass these metamorphic rocks are intruded by nonfoliate dioritic rock containing inclusions of the older rocks; further descent of the pass proved alternations of intrusive and metamorphic rock, the proportion of the latter increasing toward Thirah at the foot of the pass. The rocks are much fractured, and shear zones are common. Epidote is abundant, as streaks and patches, in rocks of all types. Dikes of andesite-basalt in this area contain inclusions of the intrusive dioritic rock. The Mukayrās pass section confirms the conclusion that dioritic (and granitic) rocks of the Mukayrās plateau belong to an intrusive phase post dating the main regional metamorphic episode.

A specimen (A98) from the Mukayrās pass at an altitude of 5,300 feet is a slightly metamorphosed medium-grained diorite, in which turbid oligoclase is the dominant feldspar. Prisms of amphibole occur, together with more abundant actinolite. The rock shows an epidote vein $1 \mathrm{~mm}$ thick. Shear lines and schistose areas are conspicuous in thin section. Dark fine-grained inclusions may be recrystallized basalt or gabbro, possibly representing included mafic rock of the Aden Metamorphic Group.

A specimen of altered quartz diorite, or tonalite (A114), from the top of the Mukayrās pass, contains quartz which invariably shows strain effects; allanite is broken by deformation, and shear lines are present.

A rock (A97) consisting of epidote and albite, the latter in turbid deformed crystals, occurs in the pass in a zone of intense shearing and epidotization. This rock could have been derived from metamorphism of an anorthosite, and as the alteration shown is more intense, it may possibly be a representative of an older metamorphic rock.

The Khawrah area consists largely of hornblendic rocks, in which hornblende-plagioclase gneiss and hornblende schist are associated with nongneissose dioritic rock containing inclusions of the metamorphic rocks. Field relations suggest that nongneissose dioritic rock is of later intrusive type. It was not established what proportion, if any, of the gneissose diorite represents the result of dynamic metamorphism upon later intrusive diorite. Certain altered dioritic rocks in this locality (for example, A151, from 2 miles southeast of Khawrah), which contain apparently recrystallized quartz together with amphibole after pyroxene, may be derived by metamorphism of older gabbro accompanied by granitization. Other slightly altered dioritic rocks showing marked deformation are more certainly of the intertectonic group.

In the Wādĩ al Jif'iyah (Bayhān) district a restricted outcrop of mafic intrusive rock occurs in a predominantly granitic area. A specimen of this unusual rock (A204) consists almost entirely of bytownite and hornblende. The rock has clearly been subjected to some deformation, which has had little effect on the feldspar. 
Deformation cracks are marked by lines of finely granular hornblende and recrystallized feldspar. The rock is designated a deformed hornblende-gabbro.

Amphibole-plagioclase rock in Wädi Milh, which has undergone a moderate degree of metamorphism, is thought to belong to the intertectonic intrusive group. Deformed amphibole crystals show cataclastic effects. Mineralogy and texture suggest derivation from a uralitized and albitized gabbro.

\section{LATER MAFIC INTRUSIONS}

Intrusions of mafic rock which appear to have undergone little or no metamorphism, were seen in two areas of the Western Protectorate. These are considered to represent a probably limited phase of intrusion later than the dynamic metamorphism which affected the intertectonic mafic intrusives and earlier rocks. Their unmetamorphosed state suggests an age later than Precambrian, and possibly early Paleozoic.

On the west of the 'Ataq road, about 6 miles south of 'Ataq, are dark cone-shaped hills of gabbroic rock. Petrographic examination proved uralitized gabbro, which has a grain size of about $1 \mathrm{~mm}$ and in which fresh unzoned labradorite is present. No deformation effects were noted in this rock (A136). A mile or so nearer 'Ataq, more outcrops of this rock are flanked to the east by chloritic schists and metacalcareous rocks.

Partly uralitized leucogabbro occurs at Jabal al Munif, Al 'Anad. A specimen (A31) shows labradorite enclosed ophitically in colorless pyroxene which is partly converted to pale-brown hornblende.

In order to include all basement-rock units of the Protectorate, two further groups, which occur only in E.A.P., must be considered.

\section{OLDER VOLCANIC ROCKS}

A series of volcanic rocks crops out over extensive areas in the E.A.P., notably in the Zulm Bā Tha'lab locality, some 19 miles north-northeast of $\mathrm{Bi}^{\prime}$ ' 'Ali ; in various areas along the coast and inland between $\mathrm{Ra}$ 's ar Rujaymah and Burūn, and in Al Mukallā area. Beydoun (1961) described these rocks and named them the Tha'lab Group.

In summary, they comprise a thick series of volcanic rocks including olivine basalt, porphyritic pyroxene and hornblende andesite, keratophyres, and soda rhyolites; trachytes are scarce. Associated with the lavas are pyroclastic rocks, ranging from fine ash to coarse tuffs of lithic, vitric, and crystal type. The volcanics are predominantly of andesitic composition.

Rocks of this group were examined in several localities during the O.G.S. field survey. Specimens collected included altered volcanic tuff (A269), albitized olivineandesite (A239), and various porphyritic types. Serpentinization and epidotization are common features, and amygdales infilled with epidote occur in many of the lavas.

The older volcanic rocks have undergone intense multidirectional cleavage and fracturing; although in one locality, about 1 mile north of Ra's Muwaysah, schistose hornblende-chlorite rocks occur, these rocks in general show the effects of dynamic rather than dynamothermal metamorphism.

In Wādī Gharīsh, north of the port of Balhāf, metamorphic rocks, including staurolite-garnet-mica schist, and schists showing polymetamorphism, occur some 15 miles from Zulm Bā Tha'lab, where older volcanic rock were examined. The older volcanic rocks probably also occur very much nearer to Wădi Gharish, as suggested from photogeological mapping. To the southeast of Ma'bar, Wadi Hajr, quartzo-feldspathic gneisses are contiguous to older volcanic rocks. It is considered unlikely that the volcanic rocks cropping out so near to regionally metamorphosed rocks could have been exposed to the metamorphism which affected the latter and yet remain so little altered. In this connection it is noted that volcanic derivatives in basement rocks (Aden Metamorphic Group) of Wădi Gharish and of W.A.P., are reconstituted schistose rocks. It is suggested that the older volcanic rocks were extruded later than the main period of regional metamorphism which produced the Aden Metamorphic Group.

On the evidence of cleavage and intense fracturing, the volcanic rocks predate a phase of dynamic metamorphism. This metamorphism affected metasedimentary rocks of Wādi al Ghabar which, on the basis of contained conglomerates with volcanic fragments, are younger than the volcanic rocks and are thought to be of latest Precambrian age. The age of the older volcanic rocks might thus be somewhere between the date of the main regional metamorphism and a phase of dynamic metamorphism, possibly in late Precambrian times.

It is suggested that the older volcanic rocks of E.A.P. may be broadly coeval with the intertectonic intermediate to mafic plutonic intrusives of W.A.P., which also appear to be later than the main regional metamorphism but which have suffered deformation and cataclasis. The question is then raised as to the conditions which resulted in extrusive activity in E.A.P. concurrently with plutonic intrusion in W.A.P. In this regard it is noted that the lightly metamorphosed sedimentary rocks of E.A.P. are not recorded in W.A.P. That these younger metasedimentary rocks have been denuded from western areas, in what was a more elevated part of the shield, and with them the equivalents of E.A.P. extrusives seems a reasonable postulation.

It should be noted that Beydoun (1961) regarded the 
volcanic rocks as the oldest exposed rocks in southwestern Hadhramut. Although the view just advanced is preferred, conclusions must be regarded as tentative.

\section{GHABAR GROUP}

Weakly metamorphosed sedimentary rocks exposed in the Wādi al Ghabar area of E. A. P. have been described by Beydoun $(1960,1961)$; he named them the Ghabar Group, in which he also included rocks in limited exposures in Wādì Minhamir (Wādī Hajo basin, near Ma'bar) and in Wādì Bā'Aryat.

Rocks of Wādi al Ghabar were examined during the O.G.S. survey. In summary, the succession includes the following, described in ascending order:

At or near the base is a purple conglomerate containing pebbles and fragments of tuff, andesitic volcanic rock, chert, porphyry, crystalline limestone, and quartzitic rock. (Pebbles of pyroxenite, diorite, dolomite, siltstone, mudstone, and rare granite were also recorded by Beydoun, 1961.) The sedimentary succession is considered to lie unconformably upon older volcanic rocks, and volcanic pebbles contained in the conglomerate appear to be identical with rocks of this group exposed nearby.

Above the conglomerate are platy thin-bedded limestones containing some gypsum, and chert layers overlie the bedding. These are succeeded by a series of dolomitic rocks, calcareous sandstones, and siltstones with interbedded dolomite and gypsum layers. Overlying these are sandy dolomites, massive calcareous quartzites, thinly laminated shaly rocks of phyllitic character alternating with quartzites, and limestones.

No fossils have been recorded in these beds, and shale samples tested palynologically were devoid of fossil spores.

The rocks of Wädĩ al Ghabar are commonly steeply dipping; isoclinal folding, and in places, overfolding, is present. Intense cleavage and fracturing of arenaceous strata are seen, but the rocks show no evidence of any mineral reconstitution.

Concerning the age and relation of the Wādi al Ghabar metasedimentary rocks to other basement-rock groups, the following points are noted. The low (dynamic) metamorphic grade of these rocks contrasts strongly with regionally metamorphosed rocks of Wâdi Gharish, some 25 miles to the west, and with gneissic rocks of the Wādi Hajr area some 6 miles to the southwest. This difference could be due to deposition of the Wādi al Ghabar rocks after the main episode of regional metamorphism. Grounds for suggesting that older volcanic rocks of E.A.P. were extruded later than this period of regional metamorphism have been noted previously. These volcanic rocks evidently predated, at least in part, the Wādi al Ghabar rocks; they underwent prior denudation, and volcanic material so derived is incorporated in conglomerates of the sedimentary series. As the older volcanic extrusive period is tentatively equated with intertectonic intrusive activity in the W.A.P., deposition of Wādi al Ghabar sediments is assumed to postdate this phase. The sedimentary rocks were subsequently affected by the widespread dynamic metamorphism which produced deformation and cataclasis in all the basement rocks of the region, excepting only the posttectonic intrusive rocks. A granitic representative of the posttectonic intrusive rocks, exposed in Wādĩ al Ghabar, gives an apparent age of 562 m.y. This, together with the absence of any recorded organic remains in Wādi al Ghabar rocks, indicates a Precambrian age for the Wādi al Ghabar rocks. To exactly which period of the Precambrian they belong cannot be deduced. It is relevant, however, that age determinations on Saudi Arabian rocks give no apparent age in excess of 1,000 m.y. (Brown and Jackson, 1960). Determinations on basement rocks from W.A.P. and the former Somaliland Protectorate, made by Snelling of the O.G.S. Age Determination Unit, have as yet yielded no apparent ages in excess of some 620 m.y. (written commun., 1964). (The last date may perhaps reflect the latest period of metamorphism in the region.) While these results do not provide direct evidence as to the age of the exposed basement rocks of the Arabian shield, they do suggest that the rocks are of later Precambrian age. Since the Wādĩ al Ghabar rocks appear to belong to the uppermost basement rocks of the Protectorate, it may be inferred that they are probably of latest Precambrian age. Further, on the grounds of metamorphic grade, lithology, and relation to (older) basement metamorphic rocks, the Wādì al Ghabar rocks may be tentatively correlated with the Fatima Series of Saudi Arabia (Karpoff, 1957) and through these with the Saramuj Series of former Trans-Jordan (Quennell, 1951). This may also support the postulation of a latest Precambrian age for the Wādi al Ghabar metasedimentary rocks.

'The structural relations of the Wādi al Ghabar rocks suggest that these may be preserved in downfaulted areas. These rocks have not been recorded in W.A.P. It is possible that they were not deposited there; alternatively, and perhaps more likely, they may have been removed by denudation. The presence of spilites and keratophyres in the older volcanic rocks of E.A.P., possibly indicating formation in a basinal environment, accords with the idea that metasedimentary rocks of Wādi al Ghabar may have 
been deposited in a structural depression originating during the same general period of downwarping.

According to the views expressed above, metamorphic rocks of Wādi Gharish are to be included in the Aden Metamorphic Group that is widely exposed in W.A.P. Older volcanic rocks of E.A.P. are considered to be of later date and are correlated broadly with the p'lase of intertectonic intrusive activity in W.A.P. Rocks of Wādi al Ghabar (and associated members of Beydoun's Ghabar Group) are regarded as the latest basement rocks of the area, and probably of youngest Precambrian age.

This interpretation differs from that provisionally advanced by Beydoun (1960, 1961), who suggested that rocks of the Ghabar Group are to be correlated with those of Wādi Gharish, a westward increase in metamorphic grade being due to regional tectonic factors. Because the older volcanic rocks (Tha'lab Group) predate Ghabar Group rocks, it would follow, according to Beydoun's views, that these are older than Wādī Gharīsh rocks, and as noted, Beydoun regarded the volcanic rocks as the oldest exposed rocks of the area. On the basis of data obtained during the recent O.G.S. survey, the interpretation advanced in this report is preferred, but firm conclusions are not justified.

\section{METAMORPHISM}

At least two major phases of metamorphism have been recognized in basement rocks of the Aden Protectorate, substantiated by clear evidence of polymetamorphism in petrographic specimens. The main phase was of dynamothermal (regional) metamorphism, the effects of which were significantly augmented by extensive and broadly contemporaneous granitic invasions concentrated at a number of focal points over the territory. An important phase (or phases) of mainly dynamic metamorphism occurred at a later date. Local thermal or contact metamorphism is recorded and is due mainly to later granite intrusion, and to a lesser extent to dike intrusion.

Foliation is generally axial planar to isoclinal folds and was caused by metamorphic recrystallization. Strain-slip cleavage attributed to the later period of stress is present both in older metamorphic rocks and later members of the basement complex. In the older rocks this cleavage does not obliterate previous structures, which are expressed in some places as contortions of earlier schistosity.

\section{DYNAMOTHERMAL METAMORPHISM}

The effects of dynamothermal metamorphism of mainly mesozonal type are expressed over a wide area extending from southwestern Hadhramut to the vicinity of Thawr al Bahā in the west. The highest grade of metamorphism recorded is that represented by the staurolite-almandine subfacies of the almandine-amphibolite facies, as indicated in pelitic schists. Pelitic representatives of this grade were noted mainly in the eastern region; wadi concentrates from here show a few grains of kyanite. No sillimanite is recorded.

Apart from some of the earlier representatives of syntectonic granite, which may have undergone recrystallization during phases of renewal of the main regional metamorphic episode, the rocks affected by dynamothermal metamorphism constitute the Aden Metamorphic Group. Pelitic rocks are exemplified by garnet-muscovite-biotite schist from As Sufāl, Wādī Habbān. This rock, in which garnet porphyroblasts are common, shows polymetamorphism in the crumpling of a previous schistosity, the presence of two generations of quartz and mica, and the bending of mica microporphyroblasts. Garnet-staurolite schist of Wādi Gharish, E.A.P., demonstrates relic bedding at a high angle to schistosity. This is also seen at Al Musaymir and elsewhere in the Protectorate.

Psammitic rocks interbanded with pelitic types showing dynamothermal metamorphism include quartzofeldspathic schists and gneisses in which sericitization is marked. Most of these are derived from quartzofeldspathic or arkosic sedimentary rocks; some may be derived from altered granites. Other psammitic rocks include widely occurring recrystallized quartzite, quartz schists, and garnet granulites of sedimentary origin. A banded garnetiferous muscovite psammite from the Nüsah area shows recumbent microfolds which indicate that the banding results from pinched out similar folds. Polymetamorphism is again shown by contortion of a previous schistosity.

Rocks of calcareous type, including those derived from impure siliceous and magnesian limestone, are represented by tremolite schists, plagioclase-diopsidescapolite gneiss, phlogopite-tremolite marble, and widely occurring crystalline limestone, many of which are dolomitic. Quartz-hornblende-epidote-chlorite schist from Wādī Gharīsh, E.A.P., represents metamorphosed impure dolomite.

Amphibolitic schists and gneisses occur commonly throughout the basement-rock areas and show a characteristic hornblende-plagioclase assemblage, including biotite and some garnet. These, together with hornblende schists, epidote-antinolite-hornblende schists, and hornblende-chlorite-epidote schists, are considered to result mainly from dynamothermal metamorphism of mafic intrusive and volcanic rocks, but some altered calc-argillaceous sedimentary rocks may be represented. Polymetamorphic effects, such as the breakdown of hornblende under deformation, are shown in many of the rocks examined. A diopside-plagioclase gneiss 
from the Kirsh area shows an assemblage indicating an original mafic igneous rock, probably a banded gabbro. A hornblende pyroxenite from Wādī Gharīsh, E.A.P., is regarded as an altered ultramafic rock. This rock shows deformation and hydrothermal alteration.

\section{METAMORPHISM AND GRANITIZATION}

The basement rocks are subject to abrupt variation in metamorphic grade; within short distances, in some places within half a mile, rocks of the lowest greenschist facies may be replaced by those of the almandineamphibolite facies. This variation might be accounted for by the assumption that part of the Aden Metamorphic Group is of later origin and was subjected to metamorphism of epizonal type only; however, no unconformities have as yet been recognized in the group as at present defined. The observed variation could alternatively be related to the incidence of syntectonic granitic invasion, which, as noted, occurs at numerous focal points.

Temperature elevation associated with granite invasion is accepted as a major factor (if not the prime cause) in metamorphism of higher grade, and in this context it is immaterial whether emplacement is in the form of magma or migma, or a combination of both. There is evidence that metamorphism unaccompanied by syntectonic granitization results in rocks showing only a low (epizonal to lower mesozonal) grade of alteration (see Read, 1957, p. 342-344).

Field observations show that syntectonic granites form centers around which metasomatic alteration and enhanced metamorphic effects form approximately radial zones. It is suggested that the observed variation in metamorphism of the basement rocks was largely controlled by the incidence of granite invasion, which caused elevation of the grade of initially low-grade metamorphosed geosynclinal sedimentary rocks and associated mafic igneous rocks. Metacalcareous rocks occur commonly in the Aden Metamorphic Group, and these, with similarly widely occurring quartzites, form resistant bands in many granitic areas. 'These rocks may have formed barriers to metasomatism and granitization, thus contributing to the disparity in metamorphic grade from one locality to another.

Polymetamorphic and deformational effects seen in the rocks of the Aden Metamorphic Group are probably largely the result of a later period of dynamic metamorphism. There is, however, nothing to preclude such dislocation metamorphism being in part related to the main regional metamorphic phase, which would then embrace both dynamothermal and dynamic effects, the dominance of one or the other being related to the incidence of granitic invasion.

There is some evidence of retrograde metamorphism; for example, in certain pelitic rocks, it is suggested by the breakdown of garnet that lacks crystal outlines and is marginally altered to chlorite. Amphibolization of diopside and other pyroxenes, epidotized pseudomorphs, chloritized biotite, and possibly some serpentinization may also be attributed to this process.

\section{DYNAMIC METAMORPHISM}

In rocks of the Aden Metamorphic Group a later phase of metamorphism is shown by contortion of previous schistosity and in other effects of deformation. Petrographic study indicates that this later metamorphism was of epizonal type, of a grade appropriate to the lower part of the greenschist facies.

By reference to the older metamorphic rocks alone, it is possible to infer only that a renewal of stress occurred, causing metamorphism mainly of dynamic type. This might be attributed to a late phase of the main regional metamorphic episode. The metamorphic state of later rocks suggests, however, that dynamic metamorphism occurred at a separate and later period. Thus dioritic rock in the Mukayrās district contains inclusions of older metamorphic rock and is clearly of later intrusive origin. As opposed to dioritic and gabbroic derivatives in the Aden Metamorphic Group, which are now represented by hornblende-plagioclase gneiss, hornblende schists, and similarly reconstituted rocks, the later intrusive diorites and other intertectonic rocks are characterized by deformation, cataclasis, an $\mathrm{d}$ shearing; they show no advanced regional metamorphism. It is clear that they were emplaced after the regional metamorphism but were affected by later dynamic metamorphism. The dynamic metamorphism has also affected rocks of $W$ ädi al Ghabar in E.A.P., causing isoclinal folding, intense cleavage and fracturing, but no mineral reconstitution. 'The $W \bar{a} d \bar{i}$ al Ghabal rocks are considered to represent the uppermost basement rocks of the Protectorate and to be of late Precambrian age. It seems clear that a phase of dynamic metamorphism occurred toward the close of Precambrian times.

No evidence has yet been seen to support the assumption of more than two main periods of folding. It is possible therefore that the dynamic metamorphism expressed in basement rocks over the whole area may be attributed to a period of stress in late Precambrian times. In this connection it is noted that age determinations on metamorphic rocks of the Aden Metamorphic Group give no apparent ages greater than $620 \mathrm{~m} . \mathrm{y}$. This may indicate a period of metamorphism at, or shortly before, this date; that is, the apparent dating may refer to the last main metamorphic phase.

Reference has already been made to the evidence of dynamic metamorphism in rocks of the intertectonic 
intrusive group and in older volcanic rocks of E.A.P. (see under relevant subsections of basement-rock units).

\section{THERMAL METAMORPHISM}

Thermal metamorphism connected with the intrusion of granite plutons and dike rocks is demonstrated in many areas. A noteworthy example is the result of posttectonic granite of the Burūm area which intrudes andesitic volcanic rocks. A thermal aureole, some 18 inches wide where examined, is marked by andesite hornsfels showing no directional fabric.

Thermal metamorphism of calcareous rocks is illustrated by the occurrence of idocrase-wollastonite marble at Al'Anad. Calc-silicate rocks and ophicalcites are recorded from several areas, for example, Wādī Milh southwest of Lawdar.

Thermal imposed upon dynamothermal metamorphism is indicated by such effects as biotite and other porphyroblasts orientated across schistosity, as in Wādì Ahwar and Waùı üuarīsh, E.A.P.

\section{SYNOPSIS OF BASEMENT-ROCK GEOLOGY}

In the following account, rock groups are treated as far as possible in chronological order; some interpretation of the probable geological history is included. The main divisions of basement rocks are summarized in table 3. The area of basement rocks in the Protectorate is about 8,500 square miles, excluding outcrops of small extent at Ra's Sharwayn. By far the greater part is exposed in W.A.P. in two areas of very unequal size. The main area is separated from Jurassic and younger sedimentary rocks to the east by a zone of faults that extend northwest from the locality of 'Irqah. It is bounded on its northern sector by the Ramlat as Sab'atayn and the Yemen border, and on the west by the Aden Trap Series, from which it is separated by a fault zone extending northwest from a point in the coastal plain north of Aden. The second and smaller area of basement rocks lies to the northwest of Aden. It is flanked to the east and west by volcanic rocks and on the south by the coastal plain; it extends northward across the border into Yemen.

Apart from relatively narrow, elongate outcrops of Jurassic and Cretaceous sedimentary-rock that occur in the coastal region, the main basement outcrop is concealed over an extensive area by basalt flows extending inland from the coast between Shuqrah and Ahwar.

In the Eastern Protectorate the main basement outcrops occur in the Jiball al Aswad to the northeast of Mayfa'ah, and in the general coastal area between the longitudes of Balhāâf and Al Mukallā.
TABLE 3.-Main divisions of the basement rocks

[In order to show all major plutonic intrusives, alkaline granite of post-Jurassie age is included. Post-Jurassic extrusive igneous rocks are omitted]

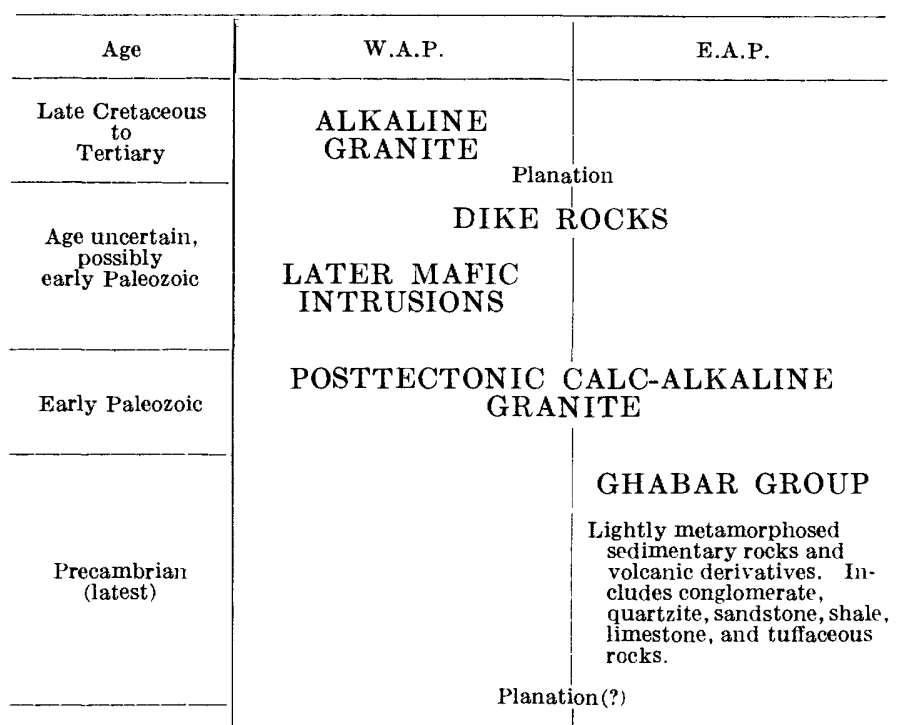

INTERTECTONIC IGNEOUS ROCKS

Dike rocks intruded mainly as a late phase of intertectonic igneous activity

Calc-alkaline granite. Contaminated rocks of

\begin{tabular}{c|c} 
Mukeiras area. \\
Intermediate mafic plutonic
\end{tabular} mainly andesites and keratophyres with pyro clastic rocks.

SYNTECTONIC GRANITE

Subautochthonous concordant granite and granitized rock approximately coeval with main phase of regional metamorphism. Associated pegmatites and feldspathic bands.

ADEN METAMORPHIC GROUP

Regionally metamorphosed sedimentary and mafic igmeous rocks, including volcanic representatives. Planation(?) OLDER GNEISS

Precambrian (earlier)

Orthogneiss of granitic composition

Orthogneiss of granitic composition exposed near Thawr al Bahā and in the Şa'îd and Nişāb areas is thought to represent the oldest rock in the Protectorate. This older gneiss is apparently not associated with surrounding rocks of the Aden Metamorphic Group, and no inclusions of the latter have been found in the gneiss. The older gneiss shows evidence of having been invaded by later syntectonic granite. Evidence as to the status of the gneiss is not sufficient to support firm conclusions. It is tentatively suggested that the gneiss represents a deeper thoroughly reconstituted autochthonous gneissose granite, which formed a massive block resistant to later tectonic stress.

Metamorphic rocks of the Aden Metamorphic Group are the most extensive of the basement groups in W.A.P.; they also crop out in several areas of southwestern Hadhramut. The group includes metamor- 
phosed sedimentary and mafic igneous rocks, some being volcanic representatives.

Original sedimentary rocks were of arenaceous, argillaceous, and calcareous type and were of varying purity. The sequence of depositional phases has not been worked out, but alternations seem to have been relatively rapid. Arenaceous rocks occur commonly as belts and bands throughout the group. They are represented by pure recrystallized quartzite, quartzsericite schists, quartzo-felspathic schists and gneisses derived from arkosic sandstone, and schistose grit.

Phases of calcareous deposition are indicated by widely occurring metacalcareous rocks, including calcite and dolomite marbles, ophicalcites and calc-silicate rocks, and epidosites. Tremolite schists and plagioclase-diopside-scapolite gneisses are recorded. Crystalline limestone or marble bands may vary greatly in thickness; thus, an aggregate thickness of several hundred feet of this limestone at Jabal ath Thaniyah may be contrasted with bands 4 feet thick in the Nüsah area. Metamorphism of impure siliceous and magnesian limestone is indicated.

Phases of argillaceous deposition are shown by the widespread occurrence of pelitic rocks such as biotite and muscovite-biotite schists. These commonly are garnetiferous and may also contain staurolite, notably in the eastern region.

Metamorphosed mafic igneous rocks, derived from intrusions into the original sedimentary rocks, make up a large part of the basement complex. Amphibolites, hornblende-plagioclase gneisses, and hornblende schists are widespread. Diopside, as well as biotite and sparse garnet, is found in some of the specimens examined. Metamorphism of gabbroic and dioritic rocks is indicated. Altered ultramafic rocks appear to be of very restricted occurrence; they are represented by hornblende pyroxenite of Wādī Gharīsh, E.A.P.

Volcanic derivatives of mafic to intermediate composition are represented by epidote-actinolite-hornblende schists, by hornblendic schists containing much epidote and albitized plagioclase, and by chloritic green schists. The altered volcanic rocks are apparently mainly of andestic type, but altered spilites are also indicated. Because distinction between metamorphosed mafic intrusives, volcanic derivatives, and impure calcareous rocks is not often possible, the relative abundance of these components is in doubt.

The thickness of the Aden Metamorphic Group, as estimated from the photogeological map, ranges between 30,000 and 40,000 feet. This estimate is an average of a number of sections, to which correction for dip has been applied, but in view of uncertainties as to the affects of folding and faulting it must be regarded as little more than an informed guess. Estimates for apparently comparable rock groups in Saudi Arabia indicate thicknesses of as much as 37,000 (Brown and Jackson, 1960) or 50,000 meters (Karpoff, 1960). For Egypt, Schurmann (1961) suggested 7,000-12,000 meters (about 23,000-39,000 ft).

The metamorphic rocks are strongly folded, generally in isoclinal folds of similar type. Planes of schistosity and foliation dip generally but not invariably at high angles between $30^{\circ}$ and $60^{\circ}$. Belts of very steep to vertical dip have been mapped, such as between 'Ataq and As Sufāl and parallel with Wādì Durā in the region to the south of Khawrah. Complicated fold structures, some involving overturning, are present (these are referred to under "Structure"). Foliation commonly is parallel with the axial planes of folds and with relic bedding, the latter being expressed by color banding or by mica- and garnet-rich layers. In some places however, marked divergence between relic bedding and foliation strike is seen, as in Wādī Gharish and near Al Musaymīr. The rocks show clear evidence of polymetamorphism and were evidently subjected to at least two metamorphic phases. Of these, the main phase - of dynamothermal typeresulted in grades reaching that represented by the almandine-amphibolite facies, as shown by pelitic rocks with garnet and staurolite. Marked variation in metamorphic grade is seen, however, and in some areas metamorphic rocks of the group are represented by quartz-chlorite-epidote rocks of the low greenschist facies. This variation is attributed mainly to the incidence of syntectonic granite invasion, a relation between foci of invasion and elevation of metamorphic grade being demonstrated in a number of areas. A later period of metamorphism, of essentially dynamic type, resulted in rocks belonging to the lower greenschist facies. The main period of regional metamorphism is associated with Precambrian orogenic moves whereas the later dislocation metamorphism is attributed to directed stress in late Precambrian times, following elevation and denudation.

Within the Aden Metamorphic Group as at present defined, no unconformities have been recognized and no great differences in overall composition are apparent from one area to another. The variation in metamorphic grade possibly suggests the presence of a younger upper division characterized by low-grade (epizonal) rocks. On the basis of present data no major division of this kind could be upheld, however, because variation in grade of metamorphism does not provide a reliable criterion and is not necessarily related to depth zoning.

The Aden Metamorphic Group is tentatively cor- 
related with the main part of the Medina Series of Saudi Arabia (Karpoff, 1960).

Syntectonic granite is in aggregate outcrop area the most extensive of the Protectorate granites. It invaded rocks of the Aden Metamorphic Group, giving rise to granitization and other metasomatic changes and affecting the grade of metamorphism over extensive zones centered on focal points of invasion. In summary, the granite appears to be intermediate between paraautochthonous and true intrusive rock, representing partly mobilized migma-magma bodies displaced upward from katazonal levels. It is, in the main, foliated or gneissose, but in part it is of homogeneous nonfoliate type-the latter in the central zones. It is associated with variably developed but generally relatively restricted migmatitic areas. Extensive zones of feldspathization are a characteristic feature; these are marked by feldspathic bands, which may show ptygmatic folding, and by feldspar porphyroblasts present in country rock for considerable distances, commonly several miles, from the center of invasion. Pegmatites, bearing garnet and muscovite but apparently without pneumatolytic ore deposits, are found in the inner zones; quartz veins tend to occur mainly in the peripheral zones.

Conclusions as to the origin of this granite are based on the sum total of field relations, textural characteristics, and petrography. The granite is considered to have been formed approximately coevally with the culmination of the main period of regional metamorphism, to the effects of which the granitic invasion materially contributed.

Some major areas of this granite are 8 miles southeast of Al Kirsh, 15 miles northwest of 'Irqah, 8 miles southwest of Lawdar, about 12 miles south of Nişāb, and also in Wādì Banā and Wādì Ab̧war.

Intertectonic igneous rocks are attributed to a phase of igneous activity that occurred later than the main period of regional metamorphism but prior to a period of dynamic metamorphism which was probably of late Precambrian date. The rocks are characterized by cataclastic and other deformation effects but show no evidence of higher grade dynamothermal metamorphism.

In W.A.P., intrusion of intermediate and mafic plutonic rock was followed, probably after only a short interval, by granitic intrusion.

Mafic igneous plutonic rocks are represented by altered dioritic and gabbroic rocks, generally without foliation but showing a partial development of schistosity in some localities. In the Mukayrās area unfoliated diorite is intrusive into hornblende-plagioclase gneiss and amphibolite of the Aden Metamorphic Group and contains inclusions of these older rocks.
The main outcrops occur in a broad belt between Mukayrās and Khawrah. More limited exposures were recognized some 12 miles northeast of Bayhān and in Wãdi Milhı, 14 miles southwest of Lawdar.

Granitic rocks of the intertectonic period form most of the Mukayrās granite area and include rocks described as calc-alkaline granite and hornblende adamellite (alkaline granite, probably of later date, has also been found in the Mukayrās area). That the intertectonic granite of this area postdated mafic intrusions is shown by the presence of dioritic inclusions in the granite, and reaction between granitic material and somewhat earlier mafic rock has resulted in contamination and the production of hybrid rocks. On the southerm periphery of the Mukayrās granite is some evidence for progressive zonal changes, hornblende granite passing through granodiorite to quartz diorite, or tonalite, and finally to hornblende diorite. There is also some indication that the central part of the granite is more biotitic and less hornblendic than the peripheral part. Further work is necessary to confirm this.

Intertectonic granitic rocks also occur in the Khawrah district where nonfoliate hornblende granite contains inclusions of dioritic rock, as at Mukayrās. Deformed syenite in this area is apparently intrusive through diorites. Granodiorite cropping out near Jabal ath Thaniyah is also thought to be of intertectonic type.

Both mafic and granitic intrusions of the intertectonic period show the effect of dislocation metamorphism by features such as deformed and bent crystals, deformation cracks, shattered and strained quartz, and shear lines visible in thin section. Numerous zones of shearing are seen in sections exposed in the locality of the Mukayrãs pass.

Older volcanic rocks are exposed over extensive areas in the Eastern Protectorate, notably at Zulm Bā Tha'lab, along the coast, and inland between Ra's ar Rujaymah and Burūm. These consist of a thick series of lavas including andesites, keratophyres, soda rhyolites, and less commonly, trachytes. Pyroclastic rocks are associated with the lavas. The rocks have been intensely cleaved and fractured, and are serpentinized and epidotized. They show little evidence of any higher grade dynamothermal metamorphism and in this respect contrast with volcanic derivatives in the Aden Metamorphic Group which are reconstituted schistose rocks. At least in part, the older volcanic rocks predate the sedimentary rocks of Wādi Ghabar and are intruded by later granites that show no deformation (posttectonic granites). They are considered to represent an extrusive phase approximately contemporaneous with the intertectonic intermediate mafic intrusions of the W.A.P. The absence of these volcanic rocks in W.A.P. (as also of metasedimentary rocks of 
Wādi Ghabar type) may be due to denudation in earlier early Paleozoic times.

Ligh tly metamorphosed sedimentary rocks exposed in E.A.P. in Wādĩ al Ghabar and in Wādi Minhamir and Wādi Bā 'Aryat constitute the Ghabar Group of Beydoun (1961). The composition of this group is summarized on page C31. Salient features include (a) the presence of volcanic derivatives in conglomerates at or near the base of the group and in interbedded tuffaceous horizons and (b) the presence of platy limestones with gypsum indicating shallow evaporitic conditions. Arenaceous rocks make up a large part of the sedimentary assemblage. The presence of volcanic derivatives which can be matched in older volcanic rocks of the area supports the conclusion that the Ghabar Group was derived by denudation of older basement rocks of the region and was deposited in one or more relatively restricted basinal depressions. No organic remains have been identified within the group, and shales tested palynologically proved barren.

The rocks of the Ghabar Group are strongly-commonly isoclinally - folded; over-folding and local thrusting are recorded. Intense multidirectional cleavage is present and arenaceous strata show marked fracturing, but, with the possible exception of an isolated occurrence of greenschists recorded by Beydoun in Wādi Bā 'Aryat and attributed by him to small-scale thrusting (Beydoun, 1961), the rocks show no sign of mineral reconstitution.

The metasedimentary rocks of the Ghabar Group appear to represent the uppermost basement rocks of the region. On the evidence of age determinations from undeformed and presumably later posttectonic granite occurring in Wādì al Ghabar and elsewhere in the same general area, and on the absence of organic remains, it is probable that the metasedimentary rocks are of latest Precambrian age. Their tentative correlation with the Fatima Series of Saudi Arabia would accord with this view. It also is probable that the dislocation metamorphism undergone by the Ghabar Group reflects a widespread phase of dynamic metamorphism which affected all the basement rocks of the Protectorate toward the end of Precambrian times and which accompanied the final orogenic moves in the region. Subsequent moves were epeirogenic.

Posttectonic granite of calc-alkaline type occurs in W.A.P. in the areas of Lawdar-Mūdiyah, Jibālan Jebel Nisīyīn, Șa'īd, Nişāb, Bayhān, and Wādī al Kayfī (south-southwest of Al Musaymīr); and in E.A.P. at Burūm, Zulm Ash Shaybah, and Wādī al Ghabar. These granites show no significant deformation or cataclastic effects, and in a number of places form discrete crosscutting intrusions with well-marked thermal metamorphic aureoles, as at Burūm. These are clearly high-level plutons. At Burūm, Wādì al Ghabar, and Múdiyah the intrusions are composite, a coarser gray granite preceding a finer red type.

Determinations made on granite from Wādì al Kayfĩ, Wādī al Ghabar, Burūm, and a locality some 10 miles northeast of Bayhān indicate an early Paleozoic age.

Intrusions of mafic plutonic rock, which do not appear to have undergone significant metamorphism, include uralitized gabbro of the 'Ataq area, and leucogabbro of Jabal al Munif, Al 'Anad. These rocks are of uncertain age; they may perhaps be connected with the phase of intrusive activity expressed mainly in posttectonic granites. The rocks of this group are referred to as later mafic intrusions.

Alkaline granite occurs at Jabal al Munif (Al 'Anad) and on the Mukayrās plateau near Mukayrās. At Jabal al Munif aegirine-riebeckite granite is intrusive into the volcanic rocks of the Aden Trap Series, of Late Cretaceous or Tertiary age. The riebeckite granite of Mukayrās cannot be dated in this way, but on petrogenetical grounds it is tentatively equated in age with the Jabal al Munif intrusion.

Dikes of both silicic and mafic rocks cut rocks of the Aden Metamorphic Group in many localities. The dikes commonly show a moderate degree of metamorphism in which effects of deformation are prominent. Typical of such rocks is a 30 -foot-wide dike of altered dolerite which cuts garnet-staurolite schist in Wādi Gharīsh, E.A.P. Pyroxene in this rock is largely uralitized and shows deformation, as do the slightly bent feldspars.

In the Mukayrās-Khawrah region dike rocks are very common. They are of doleritic and andesitic composition, and occur with felsites and quartz-feldspar porphyries. The dike range in width from about 6 to 150 feet. An altered dolerite cutting granite some 2 miles north-northeast of Mukayrās has undergone incipient greenschist metamorphism, and bent pyroxenes demonstrate the effects of stress. A porphyritic granophyre dike in the same area contains quartz full of shatter cracks. Many of the dikes in the Mukayrās area are later than the dioritic and granitic intertectonic rocks in which they occur, as shown by chilled margins against the granite and by inclusions of dioritic rock in andesite dikes of the Mukayrās pass.

Dikes affected by moderate dynamic metamorphism are considered to be of Precambrian age. They may have been intruded at various periods, but the great number of dikes associated with intertectonic rocks of the Mukayrās area suggests a major phase of dike emplacement connected with, and probably representing, a late phase of intertectonic igneous activity.

Dikes of microgranite and aplite, associated with 
areas of granite throughout the Protectorate, are connected with one or another of the granitic invasive phases.

In addition to dikes showing some degree of metamorphism, there are those in which no sign of alteration can be detected. Apart from dikes associated with the vulcanicity of the Aden Trap Series in the west of the Protectorate, none of these dikes is seen to cut Jurassic or later rocks. The undeformed dike rocks may thus be dated as pre-Jurassic, and probably of later than Precambrian age. These may be connected with lower Paleozoic granite intrusion. Dikes cutting the metasedimentary rocks of Wādī al Ghabar would fall into this category.

With regard to the history of the basement rocks the following interpretation is tentatively advanced.

The metamorphosed sedimentary rocks of the Aden Metamorphic Group represent geosynclinal deposits folded and metamorphosed during a Precambrian orogeny that was accompanied by broadly contemporaneous igneous activity. Interbedded metavolcanic rocks indicate extrusion of mafic to intermediate lavas, including some of spilitic type, during the geosynclinal phase of tectonism. Partly synchronous with this, and before the main period of regional metamorphism, intrusion of mafic, and more rarely, of ultramafic plutonic rocks occurred. This was followed by syntectonic granite invasion and granitization during the culminating and late phases of the main metamorphism. A later phase of mafic to intermediate igneous activity, represented by intertectonic igneous rocks, probably accompanied, and in part followed, elevation of the compressed zone. Mafic intrusions of this phase were soon followed by granitic intrusions, giving rise to contaminated or hybrid rocks in some areas. Following the phase of intertectonic igneous activity, renewed elevation of the compressed and metamorphosed geosynclinal rocks took place. This uplift was apparently intermittent, with periods of stillstand and concomitant local downwarping. Sediments of the type represented by the Ghabar Group were deposited at this time, probably in more than one basinal area of fairly restricted extent. No attempt can be made to define the locale of basin development, but it is likely that sediments of the Wãdi al Ghabar type were also deposited in W.A.P. (as in other regions of Arabia and Somaliland) and were subsequently removed by denudation. Stress accompanying the last Precambrian orogenic moves resulted in widespread metamorphism of epizonal type which affected all Precambrian basement rocks.

The peneplaned basement rocks of the Protectorate are unconformably overlain by Jurassic and younger rocks, beneath which the basement rocks are weathered to depths of at least 6 feet. Prior to the deposition of . the sedimentary cover, the basement rocks underwent one or more periods of planation, and it is clear, from the metamorphic state of the basement rocks and the presence of exposed intrusive rocks, that a cover of considerable thickness has been removed. Regarding the nature of this cover, in relation to older metamorphic and intrusive rocks, there is no difficulty in inferring a cover of Precambrian rocks. However, other conditions must be satisfied. The Ghabar Group of metasedimentary rocks, representing the uppermost basement rocks of the Protectorate and regarded as of latest Precambrian age, are intruded by dike rocks. This indicated the presence of a superincumbent cover, since removed. Also, although in Aden Protectorate posttectonic granites (dated as early Paleozoic by radio active age determinations) do not cut the Ghabar Group, in former Somaliland Protectorate granite of similar age (Las Bar Granite) is intrusive into the Inda Ad Series, which is probably to be correlated with the Ghabar Group. It is likely that in Aden Protectorate, cover rocks younger than the presently outcropping Ghabar Group were present at the time of early Paleozoic granite intrusion. It is possible that an additional thickness of latest Precambrian rocks provided this cover, but the conditions under which the Ghabar Group sedimentary rocks appear to have been deposited do not suggest that the original thickness of this group could have been sufficient. The possibility of a cover of volcanic rocks must be considered. The presence of Paleozoic sedimentary rocks in central Arabia and Oman and the presence of presumed Cambrian sedimentary rocks upon the equivalent of the Ghabar Group in Jordan (Saramuj Series), however render it at least as likely that the Paleozoic sedimentary strata extended over the Aden Protectorate. This may be supported by some evidence from Yemen, where Geukens records a small outcrop of apparently Paleozoic metasedimentary rocks (Geukens, 1960, p. 162). Epeirogenic elevation and tilting of the Arabo-Nubian shield, with which posttectonic igneous activity may be connected, would result in the denudation of this lower Paleozoic cover. The date of the planation(s) of the basement rocks remains, however, conjectural.

\section{REGIONAL CORRELATION OF BASEMENT ROCKS}

A review of the data on regions surrounding the Protectorate reveals significant similarities in the composition and history of development of basement rocks.

\section{YEMEN}

Basement rocks occurring in southeast Yemen, which comprise granite sacicio, jtrongly folded mica schists, 
amphibolites, and quartzites, were referred to the Precambrian by Geukens (1960) and equated with Karpoff's (1957) Medina Series of Saudi Arabia. In northern Yemen, Geukens recorded at least two groups of folded rocks separated by an unconformity. The older more extensive group represents the Medina Series, and the upper series, of folded conglomerates, altered arkose, and quartzite, is the equivalent of Karpoff's Fatima Series.

Geukens concluded that the Medina Series underwent regional metamorphism during which important granite massifs were emplaced. These massifs were peneplaned and covered by equivalents of the. Fatima Series. Traces of these remain only in the northwest part of the country. In contrast to the north strike of the older basement, a less important east-striking folding was imposed on these rocks.

Rocks of possible Paleozoic age were recorded by Geukens in a locality east of Sa'da, where a limited number of outcrops of slightly graphitic phyllitic rocks are distinguished by their metamorphic state from older basement rocks and from Jurassic rocks. Geukens considered it probable that the Paleozoic (Cambrian to Silurian?) transgression of Saudi Arabia extended into Yemen.

Karrenberg (1956) recognized that many of the granite and dioritic blocks of central and southern Yemen are of younger intrusive origin, emplaced in Upper Cretaceous to Tertiary volcanics. Most of these are of alkalic type, although calc-alkaline rocks also occur. Karrenberg concluded that the granitic intrusions are of Tertiary age, and being connected with a graben zone, they are not to be regarded as genuine plutonic rocks; rather, their occurrence under the same structural conditions as give rise to vulcanism lead to their being termed "volcano-plutons." The granites are said to be without mineral veins or zones, and were not associated with tectonic movements. A causal connection between the sinking of the Red Sea graben and the development of silicic from initially mafic magma is assumed, and it is thought that the granites may have been formed at relatively shallow depths. Alkaline granite of similar age occurs in W.A.P.

\section{SAUDI ARABIA}

Karpoff $(1957,1960)$ regarded the folded basement rocks of the Arabian Peninsula as being everywhere of Antecambrian age and he considered peneplanation to have occurred well before a Cambrian transgression. Basement rocks are divided into an older Medina Series and a younger Fatima Series; the existence of a third more ancient group is suggested by the presence of pebbles of gneiss and granite in the Medina Series.

The Medina Series includes dark lavas, mainly of andesitic type, volcanic breccias, tuffs, and conglomerates; original sedimentary rocks are represented by various schists, amphibolites, marble, quartzite, and conglomerate. Migmatite and gneiss were also recorded. Granites of various ages crop out in the series; diorites, gabbros, and serpentines are of relatively restricted occurrence.

Between Riyadh and Jiddah the Medina Series was said to be possibly more than 50 kilometers thick. It has undergone varied degrees of metamorphism resulting in rock types ranging from chlorite schist to migmatite. The folding was said to be mainly simple, with schistosity parallel to stratification. Dominant strike directions approximate northwest and northeast, and this is also the general orientation of fold axes although some folding on north-south axes was recorded.

The Fatima Series consists of volcanic rocks, striped slates or schists, limestones, and abundant arkose and conglomerate. In the type area of Wadi Fatima a partial thickness of at least $500 \mathrm{~m}$ was recorded. The series is separated from the underlying Median Series by a major unconformity and the two groups are further distinguished by a contrast in metamorphic grade, which for the Fatima Series does not exceed that appropriate to the lower greenschist facies. The younger age of the Fatima Series is supported by the presence of Stromatolites at three horizons in slightly altered limestones. Folding is orientated from north to east-southeast; northwest fold directions are not known. The "schistosity" present in some of these slightly altered beds is in places oblique to stratification. The age of the series was said to be certainly pre-Maestrichtian, and provably Precambrian.

The following correlations were tentatively proposed by Karpoff. The Medina Series was equated with the Aqaba Granite Complex of Jordan, the AtallaMitiq Series of Egypt-Sinai, and the Nafirdeib Series of Sudan. The Fatima Series was correlated with the Saramuj Series of Jordan, the Hammamat-DokhanFerani of Egypt-Sinai, and the Awat Series of Sudan.

The Saq Sandstone of northern Arabia was equated with the Quweira Sandstone of Jordan, and both were said to be of Cambrian age. (With reference to the age of the Saq Sandstone, Steineke, Bramkamp, and Sander (1958) recorded that Cruziana-like tracks are present in the upper part, but no diagnostic fossils have been found. They further stated that rocks of Cambrian age occur in the Al'Aqabah-Dead Sea area, dated by fossils, and that the Saq Sandstone has not yet been traced laterally into fossiliferous Cambrian rocks. The Saq Sandstone was, however, considered to represent the approximate lateral equivalent of Quennell's (1951) combined Quweira, Ram, and Un Sahm Series; these in turn were considered by Quennell 
to include beds equivalent to the fossiliferous Cambrian rocks.)

Brown and Jackson (1960), in describing the segment of the Arabian shield in the highlands of western Saudi Arabia, noted gneissoid belts having no apparent intrusive relations with adjoining beds, which may represent the oldest rocks exposed (compare older gneiss of W.A.P., p. C14). Most abundant of the granitic rocks are granodioritic and adamellitic types, mainly in synkinematic concordant batholiths. Age determinations for synkinematic granodiorites and related rocks indicated an apparent age of 1,000 m.y. Batholiths and stocks of calc-alkaline granite showing both concordant and discordant features were dated at about 710-750 m.y., and quartz diorite was dated at about 820 m.y. Injection granite about $600-640$ m.y. in age was recorded. Soda-rich granitic, syenitic, and rhyolitic rocks occur as plugs, stocks, and ring dikes; these rocks are apparently unmetamorphosed and undeformed; a wide age span is suggested and periods of vulcanism of middle Paleozoic and early Tertiary date may possibly be represented. Small intrusive rocks of younger diorite and gabbro were reported in the foothills near the Red Sea rift zone and were referred to as late mafic rocks. (Comments on the age determination figures cited above are included in the section on "Age determination results.")

The Hali Schist Series, considered by Brown and Jackson to include the oldest metamorphic rocks, appear to be lithologically comparable with members of the Aden Metamorphic Group. The Baish Greenstone and Lith Complex, including greenstone, metadiorite, metagabbro, and amphibolite, may correspond to metamorphosed igneous rocks in the Aden Metamorphic Group. The Halaban Andesite Group of the central and northern Arabian shield area consists of less metamorphosed intermediate and silicic volcanic rocks with intrusive intermediate and mafic rocks. These appear to correspond to intertectonic igneous rocks of Aden Protectorate. Brown and Jackson equated their Fatima and Abla Formations with Karpoff's Fatima Series. These slightly metamorphosed beds, occurring in isolated basins, were said to be gently folded, and were referred to the Precambrian. They are separated from underlying rocks by an obvious unconformity.

\section{EGYPT}

Schürmann (1961) considered the Precambrian rocks of the Red Sea region to belong to the youngest consolidated rim of the African cratonic shield. He compared them with the Riphean of Russia (Schatsky, 1960), which in the Ukraine is dated as about 570-630 m.y. and lies beneath unconformable fossiliferous
Lower Cambrian. Reviewing results of age determinations, Schürmann suggested that the rocks of the Red Sea region are generally about $600 \mathrm{~m}$.y. old and thus contrast with the Precambrian (Archaean) of the older parts of the African shield. He recognized in western Saudi Arabia and the Eastern Desert of Egypt two eugeosynclines, or two parts of one larger geosyncline, in which intense folding in the center gives way to block faulting on the shallower rim. Granitization and migmatization of katazonal sedimentary rocks in the center of the trough were recorded.

From Schürmann's account of the older rocks of Egypt, a tentative correlation with the Aden Protectorate rocks may be attempted. This is summarized in table 4. The Shaitian (syntectonic) Granites of Egypt appear to be the counterpart of Aden syntectonic granites; similarly the older Gattarian of Egypt, composed of granites and dioritic rocks, may perhaps be equated with intertectonic intrusive rocks of the Protectorate. The older Gattarian rocks are separated by an unconformity from overlying Hammamat Series, which was equated by Schürmann with the Saramuj Series of Jordan and with the Inda Ad Series of former Somaliland Protectorate.

A general correspondence between the Precambrian of Egypt and that of Aden Protectorate is also apparent from Said's (1962) account of Egyptian rocks, from which may be noted the statement that regional metamorphism of original sedimentary rocks was accompanied by metamorphism and granitization, resulting in Shaitian granites.

\section{EASTERN ADEN PROTECTORATE}

In an account of the stratigraphy and structure of Eastern Aden Protectorate, Beydoun (1961) described basement rocks cropping out mainly in southwestern Hadramawt and also at Jabal ath Thaniyah near the Yemen border. A group of older volcanic rocks, named by Beydoun the Tha'lab Group were considered by him to represent the oldest exposed rocks in E.A.P. A series of sedimentary rocks with some volcanic rocks, which have undergone regional metamorphism to the albite-epidote-amphibolite facies reaching grades with garnet and staurolite as index minerals, occurs in the Gharish-Madbi area of E.A.P. This series represents Beydoun's Gharish Group, comprising various schists, amphibolites, quartzites, and marbles. Beydoun suggested that the Gharish Group may be equivalent to virtually unmetamorphosed rocks of the Ghabar Group that crop out some $40 \mathrm{~km}$ to the east. The transition cannot be followed in the field but is attributed to increasing metamorphism from east to west. 
TABLE 4.-Tentative correlation of basement and certain other rock units of Arabia and bordering regions

\begin{tabular}{|c|c|c|c|c|c|c|c|}
\hline \multirow{2}{*}{ Age } & \multicolumn{2}{|c|}{ Aden Protectorate } & \multirow{2}{*}{ Saudi Arabia } & \multirow{2}{*}{ Yemen } & \multirow{2}{*}{$\begin{array}{c}\text { Former Somaliland } \\
\text { Proctorate }\end{array}$} & \multirow{2}{*}{ Egypt } & \multirow{2}{*}{$\begin{array}{l}\text { Former Trans- } \\
\text { Jordan }\end{array}$} \\
\hline & Western & Eastern & & & & & \\
\hline Tertiary & Alkaline Granite. & & $\begin{array}{l}\text { Representtives of } \\
\text { Late Alkalic Rocks } \\
\text { (Brown and Jack- } \\
\text { son, 1960). }\end{array}$ & $\begin{array}{l}\text { Granitic intrusions } \\
\text { mainly of alkalic } \\
\text { type (Karrenberg, } \\
\text { 1956). }\end{array}$ & & $\begin{array}{l}\text { Tertiary(?) pluto- } \\
\text { nism (Higazy and } \\
\text { El Ramly, cited } \\
\text { by Schürmann, } \\
\text { 1961). }\end{array}$ & \\
\hline $\begin{array}{c}\text { Early } \\
\text { Paleozoic }\end{array}$ & \multicolumn{2}{|c|}{ Posttectonic calc-alkaline granites } & $\begin{array}{l}\text { Posttectonic Granites } \\
\text { (Karpoff, 1960). } \\
\text { Representatives of } \\
\text { Late Alkalic Rocks, } \\
\text { including granite. } \\
\text { Shammer Rhyolite } \\
\text { (Brown and } \\
\text { Jackson, 1960). }\end{array}$ & $\begin{array}{l}\text { Certain intrusive } \\
\text { Granites } \\
\text { (Geukens, 1960). }\end{array}$ & $\begin{array}{l}\text { Posttectonic "Young- } \\
\text { er" Granites includ- } \\
\text { ing Las Bar, Arar, } \\
\text { and (?) Daimoleh } \\
\text { Granites. }\end{array}$ & $\begin{array}{l}\text { Younger Gattarian } \\
\text { including granite } \\
\text { (Schürmann, } \\
\text { 1961). }\end{array}$ & \\
\hline Cambrian & & & $\begin{array}{l}\text { Saq Sandstone } \\
\text { (Steineke, } \\
\text { Bramkamp, and } \\
\text { Sander, 1958). }\end{array}$ & $\begin{array}{l}\text { Paleozoic(?) phyl- } \\
\text { litic rock } \\
\text { (Geukens, 1960). }\end{array}$ & & & $\begin{array}{l}\text { Quweira Series, } \\
\text { mainly arena- } \\
\text { ceous and con- } \\
\text { glomeratic } \\
\text { (Quennell, 1951). }\end{array}$ \\
\hline $\begin{array}{c}\text { Late } \\
\text { Precainbrian }\end{array}$ & & $\begin{array}{l}\text { Ghabar Group } \\
\text { (Beydoun, 1961). }\end{array}$ & $\begin{array}{l}\text { Fatima Series } \\
\text { (Karpoff, 1957, } \\
\text { 1960). Fatima and } \\
\text { A bla Formations } \\
\text { (Brown and } \\
\text { Jackson, 1960). }\end{array}$ & $\begin{array}{l}\text { Fatima Series } \\
\text { equivalents } \\
\text { (Geukens, 1960). }\end{array}$ & Inda Ad Series. & $\begin{array}{l}\text { Hammamat Series } \\
\text { (Schürmann, } \\
\text { 1961). }\end{array}$ & $\begin{array}{l}\text { Saramuj Series } \\
\text { (Quennell, 1951). }\end{array}$ \\
\hline \multirow{3}{*}{ Precambian } & \begin{tabular}{|l|} 
Intertectonic igneous \\
rocks \\
Intermediate \\
mafic intru- \\
sions followed \\
by granitic in- \\
trusions. Hy- \\
brid rocks of \\
Mukeiras- \\
Khawrah.
\end{tabular} & $\begin{array}{l}\text { Intertectonic igneous } \\
\quad \text { rocks } \\
\text { Older volcanic rocks } \\
\text { (equal to } \\
\text { Tha'lab Group } \\
\text { of Beydoun, } \\
\text { 1961). }\end{array}$ & $\begin{array}{l}\text { Upper part of Medina } \\
\text { Series (Karpoff, } \\
\text { 1960). Calc-alkaline } \\
\text { Granite Series and } \\
\text { Halaban Andesite } \\
\text { (Brown and } \\
\text { Jackson, 1960). }\end{array}$ & $\begin{array}{l}\text { Components of } \\
\text { Medina Series } \\
\text { equivalents as de- } \\
\text { scribed by } \\
\text { Geukens (1960). }\end{array}$ & $\begin{array}{l}\text { Mafic Intermediate } \\
\text { intrusions followed } \\
\text { by granite intru- } \\
\text { sions (Mason and } \\
\text { Warden, 1956; } \\
\text { Gellatly, 1960). } \\
\text { Hybrid granite- } \\
\text { gabbro; Sheikh } \\
\text { gabbro (Hunt, } \\
\text { 1960). }\end{array}$ & $\begin{array}{l}\text { Older Gattarian-- } \\
\text { granite and dio- } \\
\text { ritic rock. } \\
\text { Dokhan Series } \\
\text { (Schürmann, } \\
\text { 1961). }\end{array}$ & $\begin{array}{l}\text { (?) Pink Granite of } \\
\text { Aqaba Granite } \\
\text { Complex } \\
\text { (Quennell, 1951). }\end{array}$ \\
\hline & \multicolumn{2}{|c|}{$\begin{array}{l}\text { Syntectonic granite } \\
\text { Concordant granites and granitized } \\
\text { rocks, approximately coeval with the } \\
\text { main phase of regional metamor- } \\
\text { phism. Pegmatites and feldspathic } \\
\text { bands associated with granitic rocks. }\end{array}$} & $\begin{array}{l}\text { Syntectonic Granite } \\
\text { (Karpoff, 1957). } \\
\text { (?) Syntectonic } \\
\text { granodioritic and } \\
\text { related rocks } \\
\text { (Brown and } \\
\text { Jackson, 1960). }\end{array}$ & $\begin{array}{l}\text { Granite massifs } \\
\text { emplaced during } \\
\text { regional meta- } \\
\text { morphism } \\
\text { (Geukens, 1960). }\end{array}$ & $\begin{array}{l}\text { Synorogenic Granite } \\
\text { (Gellatly, 1960). } \\
\text { Metasomatic } \\
\text { granite (Mason } \\
\text { and Warden, 1956). }\end{array}$ & $\begin{array}{l}\text { Shaitian Granite } \\
\text { Granodiorite, fo- } \\
\text { liated in part } \\
\text { (Schürmann, } \\
\text { 1961). Metaso- } \\
\text { matised Older } \\
\text { (Shaitian) } \\
\text { Granities (Said, } \\
\text { 1962). }\end{array}$ & $\begin{array}{l}\text { Gray Granite of } \\
\text { Aqaba Granitc } \\
\text { Complex } \\
\text { (Quennell, 1951). }\end{array}$ \\
\hline & \multicolumn{2}{|c|}{$\begin{array}{l}\text { Aden Metamorphic Group } \\
\text { Regionaly metamorphosed sedimen- } \\
\text { tary and mafic igneous rocks, and } \\
\text { volcanic representatives, including } \\
\text { Beydoun's (19t51) Gharish and } \\
\text { Thaniya Groups. }\end{array}$} & $\begin{array}{l}\text { The major part of } \\
\text { Medina Series } \\
\text { (Karpoff, 1960). } \\
\text { Hali Schist, and } \\
\text { Baish Greenstone } \\
\text { and Lith Complex } \\
\text { (Brown and } \\
\text { Jackson, 1960). }\end{array}$ & $\begin{array}{l}\text { Medina Series } \\
\text { equivalents } \\
\text { (Geukens, 1960). }\end{array}$ & $\begin{array}{l}\text { Metamorphic rocks } \\
\text { of the Basement } \\
\text { Complex-meta- } \\
\text { morphosed sedi- } \\
\text { mentary, volcanic, } \\
\text { and mafic igenous } \\
\text { rocks including } \\
\text { Kalaha, IIudiso } \\
\text { and Barkasan } \\
\text { Series (IIunt, 1960). }\end{array}$ & $\begin{array}{l}\text { Old Paraschists } \\
\text { including vol- } \\
\text { canics. A talla } \\
\text { Series-metamor- } \\
\text { phosed sedimen- } \\
\text { tary and volcanics } \\
\text { rocks } \\
\text { (Schürmann, } \\
\text { 1961). }\end{array}$ & $\begin{array}{l}\text { Metamorphic } \\
\text { rocks of the } \\
\text { Aqaba Granite } \\
\text { Complex } \\
\text { (Quennell, 1951). }\end{array}$ \\
\hline $\begin{array}{l}\text { Earlier } \\
\text { l'recambrian }\end{array}$ & Older Gneiss. & $\begin{array}{l}\text { (?) Evidence of } \\
\text { Older Gneiss in } \\
\text { derived } \\
\text { pebbles. }\end{array}$ & $\begin{array}{l}\text { Orthogneiss of Gneiss } \\
\text { belts (Brown and } \\
\text { Jackson, 1960). }\end{array}$ & & $\begin{array}{l}\text { Older Granite } \\
\text { Gneiss. } \\
\text { Daarbuduq Series, } \\
\text { mainly geneissic } \\
\text { Granite (Hunt, } \\
\text { 1960). }\end{array}$ & $\begin{array}{l}\text { Mitiq-Feiran } \\
\text { Orthogneiss } \\
\text { (Schürmann, } \\
\text { 1961). }\end{array}$ & \\
\hline
\end{tabular}


Metamorphic rocks exposed in the area of Jabal ath Thaniyah were named by Beydoun (1961) the Thaniya Group. He noted that Thaniya and Gharish Group rocks represent about the same grade of metamorphism and suggested that the two may be lateral variants. However, on the grounds that the thick-bedded calcareous rocks of Jabal ath Thaniyah are absent in Wādi Gharish, he believed that the Thaniya Group may represent an older sedimentation that marked the start of a sedimentary cycle later completed farther south in E.A.P. and W.A.P.

Slightly metamorphosed sedimentary rocks occurring in Wādi al Ghabar and elsewhere in this locality were named the Ghabar Group. These are described on pages C31-C32. At Wădĩ Minḩamir a basal formation of the group, consisting mainly of pyroclastic material, rests unconformably upon Tha'lab Group volcanic rocks. Isoclinal folding of the sedimentary rocks is not accompanied by any mineral reconstitution.

Beydoun considered that formation of the volcanic Thalab Group mainly predated deposition of the Gharish and Ghabar Groups, but suggested that deposition of the Thaniya Group may have been initiated before the extrusive activity and that deposition and extrusion may have then proceeded concurrently. Volcanic rocks in the upper part of the Thaniya Group were thought possibly to relate to the same period of vulcanicity as resulted in the Tha'lab Group of southwestern Hadramaut.

The exposed basement rocks of E.A.P. are assumed to rest upon an older metamorphic series exposed to the west, which in turn overlies a more massive basement assemblage that is not exposed. A tentative correlation of W.A.P. basement metamorphic rocks with the Medina Series (of Saudi Arabia) was suggested by Beydoun (1961).

The tentative conclusions reached by Beydoun are supported by further observations too numerous to recount here. Following the study of the W.A.P. basement rocks made in the recent survey, however, the present authors are led to suggest alternative relationships for the E.A.P. basement groups. Reference to the Tha'lab Group volcanic rocks is made elsewhere in this contribution (p. C40), where reasons are given for dissenting from the view that these rocks predated regionally metamorphosed rocks of the area, and for suggesting their equivalence to the intertectonic igneous rock of W.A.P. The metamorphic rocks of $W \bar{a} d \bar{i}$ Gharish appear to be similar in all respects to those exposed over wide areas of W.A.P.; they are therefore included in the Aden Metamorphic Group. Although the last is to be tentatively correlated with the Medina Series (as remarked by Beydoun), the metasedimentary rocks of the Ghabar Group are thought to be of latest
Precambrian age and to be equivalent to the Fatima Series of Saudi Arabia.

\section{FORMER SOMALILAND PROTECTORATE}

During the last decade, much work has been done on the basement rocks of this region, most of which is recorded in published and unpublished reports of the former Somaliland Protectorate Geological Survey. No generalized account has been seen, but a review of the work of various authors discloses several points on which a fair measure of agreement exists. The following synthesis results from interpretation of their reports.

Pre-Jurassic rocks may be initially divided into two major classes, namely, an extensive series of igneous and metamorphic rocks and a more restricted series of lightly metamorphosed sedimentary rocks typified by the Inda Ad Series of the northeast coastal area. Reference to basement rocks in the following discussion does not include the Inda Ad Series unless specifically stated.

Basement rocks of former Somaliland Protectorate contain a large proportion of metamorphosed sedimentary rocks including psammites, pelitic rocks, and metacalcareous rocks. Psammites appear to be dominant, and observations in several areas suggest that these may be basal to the metasedimentary succession, being followed by pelitic or semipelitic rocks. At least in some areas, metacalcareous rocks are sufficiently concentrated at higher levels to warrant postulation of an uppermost limestone series, for example, in the Hargeisa District (J. L. Daniels, unpub. data, 1959). However, marble and other metacalcareous rocks are distributed throughout the succession.

The widespread occurrence of plagioclase amphibolites in metamorphosed sedimentary rocks, notably in the pelitic series, is fairly generally agreed to indicate altered mafic intrusive rocks, and these for the most part were intruded prior to regional metamorphism (J. E. Mason, unpub. data, 1954). Representatives of metamorphosed mafic volcanic rocks have been recorded in the pelitic series, and in the Borama District Mason suggested that certain chlorite schists and aphanitic amphibolites may be the products of contemporaneous submarine vulcanism. Metamorphosed rhyolites appear to occur near the top of the basement succession. W. C. White (unpub. data, 1955) recorded sheared mafic volcanic rocks and rhyolites in the pelitic series of the Western Borama District.

Synorogenic granite emplacement is substantiated in numerous areas and granitic invasion in a number of stages is recognized. References to migmatization and to the development of granite in situ are numerous. The latter is variously attributed to anatexis, meta- 
somatism, or granitization, and is particularly associated with psammitic rocks. White (unpub. data, 1955) stated that many of the rocks of Western Borama District are the product of the admixture of granitic fluids with sedimentary or mafic igneous rocks, and he considered anatexis to mark a late stage of regional metamorphism. Hunt (1958), reporting on the geology of the Adadleh area, referred to granitized rocks of the Daarbuduq Series and granitized psammites of the Kalaha Series which are in places completely converted to granite. A similar transition through granitoid rocks to granite has been reported from many areas. Feldspathization around granite centers has been recorded; for example, A. J. Warden (unpub. data, 1959 , on basement rocks of areas in the Berbera District) referred to extensive feldspathization of metasedimentary rocks surrounding a main granite mass. It may be concluded that the development of granite or granitic rock from metamorphosed sedimentary rocks by the process generally described as granitization is a major feature of the basement geology. The majority of authors correlated the main phase of granite invasion and granitization with the culminating or late stages of regional metamorphism. Hunt (1958), however, recognized granitization at various stages in the history of the basement rocks.

Mafic intrusions, including diorite and gabbro, appear to have postdated the main syntectonic granites (see Gellaty, 1960 , p. 33, on the Las Dureh area). Mafic rocks have been intruded by later granite, and marginal hybridization or contamination has occurred, as recorded by Hunt (1958) near Sheikh; rock types so produced include quartz diorite and syenodioritic rocks.

Posttectonic granites of clearly intrusive type are known from a number of areas, for example the Las Bar granite of the Elayu area (Greenwood, 1960).

Over much of the basement-rock area metamorphism in the lowest subfacies of the almandine-amphibolite facies seems to be dominant, but there is evidence for advance to the granulite facies in certain areas. Metamorphism in the greenschist facies is shown in some rocks that are possibly younger, including the Inda Ad Series. Evidence supports the assumption of at least two periods of metamorphism and folding, and some data suggest that the later episode was basically of stress metamorphism. Hunt (1958) suggested numerous metamorphic phases.

Authors consulted generally referred the basement rocks to the Archean, but with the changing usage of this term it is difficult to know what is implied. Several authors, however, considered the Somaliland rocks to be younger than the older basement rocks of central and east Africa and this is supported by recent age determinations on rocks of the former Somaliland Pro- tectorate (N. J. Snelling, written commun., 1964) which suggest that these are to be regarded as later Precambrian.

The necessarily generalized interpretation given here discloses points of striking similarity between the basement rocks of former Somaliland Protectorate and those of Aden Protectorate. This similarity is reinforced by more specific observations.

Mason and Warden (1956) in their report on an area in the Erigavo District recorded plagioclase amphibolites in the older basement rocks, indicating intrusion of mafic igneous rocks into sedimentary rocks prior to metamorphism. Metasomatic granite is reported. Dioritic rocks containing xenoliths of metasedimentary rocks appear to have been intruded at a later stage in the history of the older basement development (see intertectonic intrusions of W.A.P., p. C29).

In a report on the Las Dureh area of the Burao District, Gellatly (1960 abstract) stated that basement rocks consist of a series of psammitic, pelitic, and calcareous sedimentary and associated volcanic rocks, which have undergone metamorphism varying from the greenschist facies to the granulite facies, with accompanying folding, metasomatism, and synorogenic granite emplacement. Both plutonic and hypabyssal mafic intrusive rocks are present. At least two periods of folding separated by a period of thrusting are recognized in the basement rocks.

Concerning the Inda Ad Series, Mason and Warden (1956) suggested that this rests unconformably upon the basement complex, and they referred to conglomerates at the base of the Inda Ad succession. The presence of a strictly basal conglomerate has been questioned by Greenwood $(1960,1961)$ who discusses alternative relationships between the Inda Ad Series and other basement rocks. Recent work on Somaliland rocks by Snelling of the O.G.S. Age Determination Unit tends to support a younger age for the Inda Ad Series, relative to that for the basement complex. No firm conclusions regarding the age relations of these rock groups are reached by Snelling, and all that can be said is that a simple interpretation of available results, leaving aside complicating factors, suggests metamorphism of the basement complex before 602 m.y. and deposition and dynamic metamorphism of the Inda Ad Series before $502 \mathrm{~m} . \mathrm{y}$. It cannot be concluded that the dynamic metamorphism of the Inda Ad Series was necessarily later than the most recent phase of metamorphism of the basement complex.

Taking into account the absence of polymetamorphic effects in the Inda Ad Series and the similarity of these rocks to latest Precambrian rocks of the Arabian Peninsula, the balance of recent evidence suggests 
that the Inda Ad Series is younger than the basement complex of former Somaliland Protectorate.

The equivalence of the older basement rocks (basement complex) of former Somaliland Protectorate to the basement rocks of Aden Protectorate is indicated in the preceding review. On the basis of lithology, type and grade of metamorphism, and relation to other (older) basement rocks, the Inda Ad Series is tentatively correlated by the authors with the Ghabar Group of E.A.P. A number of posttectonic granite intrusions in both Somaliland and Aden Protectorate appear, on the basis of age determination results, to have a comparable early Paleozoic age. (See p. C93.)

\section{SUMMARY}

The suggested correlation between basement and certain other rock groups of regions of Arabia and bordering territories is summarized in table 4 . This has been prepared from a review of relevant literature and from personal observations in Aden and former Somaliland Protectorate. The correlations shown are tentative and approximate only.

It is likely that basement rocks exposed in eastern Egypt, Jordan, Saudi Arabia, Yemen, Aden Protectorate, and former Somaliland Protectorate, and possibly also in Sudan and Eritrea, represent an upper Precambrian section of the African basement complex formed on the margin of the greater African Shield. The original sediments of the lesser Arabo-Nubian Shield were deposited in one or more extensive geosynclines. During later Precambrian times, events in the region seem to have followed the usual sequence of evolution of an orogenic belt. Sedimentation and igneous activity including vulcanism were followed by compression, regional metamorphism, granitization, and migmatization. Uplift of the compressed zone alternated with periods of stillstand during which igneous intrusive activity in some regions coincided with extrusive activity elsewhere. The history of sedimentation and extrusive activity indicates oscillations of level throughout later Precambrian times.

Marked shallowing or emergence, which occurred at some time near the end of the Precambrian, is indicated by unconformities, associated with conglomerates or boulder beds, beneath the Fatima Series of Saudi Arabia and its equivalents elsewhere. Unconformities are not proved in all regions, and it is probable that Fatima Series and equivalents were deposited in relatively local basins formed on the uplifted older basement rocks and that shallowing to the point of emergence was attained in some regions but not in others. Sedimentary rocks were derived from the exposed older basement rocks.
A later phase of renewed orogenic compression, of diminished severity, caused folding of the latest Precambrian rocks and imposed cleavage and a varying, but generally slight, degree of metamorphism. This phase marked the last incidence of orogenic folding recorded in rocks of the region. There followed epeirogenic uplift which has continued, with alternating periods of stability and rejuvenation, until Recent times.

\section{ADEN TRAP SERIES}

The term "Trap Series" is applied to volcanic rocks occurring exclusively in the southwestern part of the Protectorate, which are considered to be of Late Cretaceous or early Tertiary age and are distinguished from later rocks of the Aden Volcanic Series. The Aden Trap Series corresponds, at least in part, to the volcanic rocks in Yemen referred to by Geukens (1960) as "Trappserie."

The Aden Trap Series crops out over a total area of about 1,400 square miles, in two main regions, namely:

1. To the north and northwest of Al 'Anad, extending to the Yemen border (and beyond) between Sanāby (north of Aḍ Dāli' and Al Kirsh.

2. To the north and northwest of Jabal Kharaz, again extending to the Yemen border.

Between these two regions of volcanic rocks, basement rocks are exposed. The eastern area of volcanic rocks is separated from basement rocks to the east by a zone of faulting running roughly northwest to north-northwest, east of a line between Aḍ Dāli' and Al 'Anad.

The rocks consist of a thick series of dominantly basaltic lavas, with andesitic, trachytic, and rhyolitic representatives. Interbedded with these are tuffs, agglomeratic beds, and ash. The stratified series is cut by numerous dikes of composition similar to that of the lavas; many of these are porphyritic, and, in contrast with most dikes of basement-rock areas to the east, are unmetamorphosed. Dikes of granitic composition in the volcanic rocks are associated with intrusive granite. Sills of mainly doleritic composition are common, and certain possible laccolitic bodies of similar type are recorded, for example, on the Yemen border, north-northwest of Ash Shațt. The dikes and sills are of variable thickness; many of those seen were between 6 and 9 feet thick. They cut not only volcanic rocks but also Jurassic and Cretaceous strata.

The thickness of the volcanic series has been estimated from aerial photographs by the use of a parallax bar. At Ad Dubiyat some 7 miles south of Ab Dālis, quasi-horizontal volcanic strata exceed 2,600 feet in thickness; in the Aḍ Dāli' area a thickness of more than 3,000 feet is estimated. These figures must be regarded 
as very approximate, and the maximum thickness of the volcanic rocks may well exceed 3,500 feet. In many areas thicknesses cannot be estimated because of repetition by strike faults.

Where undisturbed by faulting the stratiform volcanic rocks are quasi-horizontal. The rocks are, however, much affected by faults, mainly trending approximately northwest, which produce tilted blocks in which the rocks dip at moderate angles to the northeast or southwest; the resulting terrain is in the form of a series of subparallel ridges. This strike faulting is indicated on aerial photographs by the fact that flows of differing composition (and hence of differing weathering resistance) and of differing tone are thrown into juxtaposition. Numerous faultline scarps are produced. Cross faults, generally minor, disrupt the continuity of the ridges.

\section{DISTRIBUTION OF ROCK TYPES}

During the course of the survey, a general tendency was noted for lavas of mafic type to underlie those of more silicic composition. This also appears to be so in comparable rocks of Ethiopia, where Lamare (1930) cited Blanford as distinguishing a lower group of basalts and dolerites and an upper group of trachytes(?), considered by Lamare to be rhyolites. In Aden Protectorate this twofold division is confused by the presence of mafic layers in the more silicic rocks. Many of the mafic layers are thought to represent sills.

Volcanic rocks in the Al'Anad locality include olivine basalts, rhyolites, tuffs, and agglomerate, with doleriticbasaltic sills and dikes; porphyritic dike rocks occur. A traverse by road from Al 'Anad to Aḍ Dāli', and northward to Sanăh on the Yemen border, shows that the volcanic rocks are predominantly of basaltic lavas, in which olivine and amygdaloidal calcite are conspicuous. Lavas are interbedded with agglomerates and red ash. The stratiform appearance is accentuated by the presence of doleritic sills which forms resistant layers in lava.

In the Al Musaymir area, basaltic rocks are again predominant, but representatives of trachytic lava occur.

In Wādi Timnān, above Ash Shațt, olivine basalt is in terbedded with tuff and cut by dikes of silicic porphyry and dolerite. Near the Yemen border, north-northwest of Ash Shatt, banded rhyolites are common.

Aerial photographs of volcanic rocks exposed in Wādi Tarbahah for some miles above Ghayl Barbar, in the most western region of the Protectorate, indicate mainly in termediate to silicic rocks, which form dissected ridges in which fault-tilted flows strike northwest and northnorthwest and dip in a general southwest direction. Field observations confirm this. A section immediately to the west of the wadi at Ghayl Barbar shows, in descending order: feet)

Capping of massive dense red cherty lava (rhyolitic) _._- 90

Shaly-weathering yellow-green tuff _._.

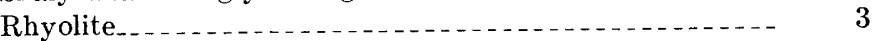

Vesicular basalt-andesite.......................... 20

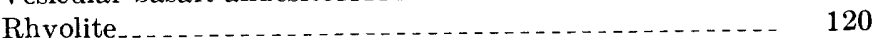

Yellow-green tuff _.............................. 10

Gray weathered trachytic lava_................... 3

Base of section not exposed.

The lavas have a stratiform appearance resulting from flow layers generally 6-8 inches thick. Mafic and intermediate dikes cut these rocks.

The dominance of silicic volcanic rocks in the Ghayl Barbar area suggests that younger rocks of the series are here exposed.

\section{MORPHOLOGICAL EXPRESSION}

The volcanic rocks form rough terrain dominated by ridges trending northwest, formed from tilted elongate fault blocks of relatively restricted width. This type of terrain is interspersed with outcrops of nearly horizontal stratiform rocks, the tabular expression of which is emphasized by resistant layers of massive basaltic lava or doleritic sills interlayered with more easily weathering vesicular lava. Tuff and ash interbedded with lavas form multicolored, shaly-weathering horizons which also add to the stratiform appearance of the rocks. In several areas, striking tiered buttelike masses consist mainly of massive basalt, many with welldeveloped columnar jointing. Above and below Al Musaymir, plateau terraces of boulders and clay, spread with volcanic pebbles, are deeply dissected by the Wädi Tuban and its tributaries. In several areas, such as near Aḍ Dāli', cultivable soils are formed on the volcanic rocks. Such flat areas are broken by dikes of the volcanic series.

Dikes of mafic and silicic composition are very numerous and impart a ribbed appearance to the country, being generally more resistant than the extrusive and pyroclastic rocks. This is well seen in the Al 'Anad area. Most resistant are dikes of porphyritic type. In the Cretaceous sandstone of the 'Awäbil area, as elsewhere, dolerite dikes form reduced negative features.

The rugged nature of the volcanic terrain is accentuated by the occurrence of spinelike volcanic necks and vents.

\section{PETROGRAPHY}

The petrographic characteristics of the Aden Trap Series and associated dike rocks are illustrated in the following examples.

Dominant among the lavas are basalts bearing olivine and including calcite forming amygdaloidal fillings. 
These basalts may occur as massive rocks or as stratiform flows of little thickness. Specimen A20, from 4 miles north of $A d ̣ D^{2}{ }^{i} i^{\prime}$, is an unmetamorphosed olivine basalt with partly serpentinized microphenocrysts of olivine in a granular groundmass of pyroxene, plagioclase, and iron ore.

A dike rock of ophitic olivine microgabbro or basalt, 1 mile north of Aḍ Dāli', shows plates of augite, 2-3 mm in length, which enclose turbid plagioclase laths and are associated with serpentinous pseudomorphs after olivine. Radiating aggregates of fibrous zeolite have replaced part of the rock (A19).

In the $\mathrm{Al}$ Anad area a dike of porphyritic basalt cuts Cretaceous sandstone. This rock (A2) shows phenocrysts of labradorite in a groundmass of calcic plagioclase, clinopyroxene, biotite, and iron oxide minerals. Phenocrysts average $5 \mathrm{~mm}$ in diameter.

Andesitic rocks are represented by $\mathrm{A} 47 \mathrm{~b}$, which is an altered quartz-andesite from a dike of Wādi Jadin, north-northeast of Jabal Kharaz. Abundant plagioclase laths occur in a turpid groundmass of brown glass, quartz, iron oxide minerals, and flakes of mica. Plates of a carbonate mineral and quartz appear to be secondary. Andesitic dike rock is also recorded from Ghayl Barbar.

Trachyte from the roadcut $2 \frac{1 / 2}{2}$ miles southeast of $\mathrm{Al}$ Musaymir (A35) consists almost entirely of alkali feldspar in small laths in parallel orientation. Scattered patches of carbonate and minute octahedra of magnetite occur. Elongate stringers of quartz lie parallel to the flow direction.

A dike about 6 miles north-northeast of Al 'Anad is composed of porphyritic flow-banded glassy trachyte, in which rhombshaped phenocrysts of alkali feldspar, $2 \mathrm{~mm}$ in diameter, are commonly zoned and have cores of altered plagioclase (A12).

Dacite-porphyry dike rock from Wādī Jadin (A47a) shows rhombshaped phenocrysts of albitized plagioclase $2-3 \mathrm{~mm}$ in diameter in a holocrystalline groundmass of quartz and plagioclase.

Spherulitic rhyolite from Al 'Anad (A1) shows spherulitic masses of epidote and granophyric "fans," as much as $7 \mathrm{~mm}$ in diameter, in very fine grained granophyric material.

Vitric tuff from the Ghayl Barbar section, noted above, consists of crystals of quartz and feldspar, with fragments of earlier pumice, in a pumiceous matrix containing abundant glassy shards (A56). A bedded crystal pumice-Tuff with inclusions of volcanic glass (obsidian?), is recorded 3 miles west of Dār Rahbān.

\section{RHLATIONS WITH ADJOINING ROCKS}

It has been noted that volcanic rocks of the Aden Trap Series are separated from relatively elevated basement rocks to the east by a fault zone east of the Aḍ Dāli'-Al 'Anad line. Along this zone Jurassic and Cretaceous sandstone is preserved in faulted blocks, and the field relations indicate that the volcanic rocks are underlain by Cretaceous sandstone over the whole region. This accords also with observations in Yemen (Geukens, 1960).

In several localities-for example, northeast of $\mathrm{Al}$ Kirsh and northwest of Ash Shaț-Cretaceous rocks are associated with volcanic rocks over fairly limited areas, and this appears to be due to faulting along mainly northwest trends. In the west and southwest of 'Awābil, Cretaceous sandstone resting on basement rocks is cut by doleritic dikes of the Trap Series, and about 8 miles southwest of this center, volcanic rocks are thrown down against sandstone by strike faults, trending northwest, which result in complicated repetition of the rock types. Similarly, about 2 miles southeast of Al Musaymir, a tilted block of Cretaceous quartzitic sandstone, in which beds dip east-northeast, is displaced against volcanic rocks by a northwesttrending fault along the Al Musaymir road. Volcanic rocks on the northeast side of the road dip to the west-southwest. Further to the west-southwest of $\mathrm{Al}$ Musaymir, volcanic rocks rest upon Cretaceous sandstone, and both sedimentary and volcanic rocks are affected by faulting, resulting in tilted blocks in which dip is to the southwest.

Owing to the prevalence of this faulted relationship between Cretaceous sandstone and volcanic rocks, evidence as to their original relation is difficult to obtain. It is possible that volcanic rocks are interbedded with latest Cretaceous rocks, but data on this point are equivocal. Thus, about 12 miles southeast of Al Kirsh, on the southeastern margin of the Wādi al Kayfi basement rocks, a small outcrop of Cretaceous sandstone provides a section about 20 feet thick. This section shows an uppermost few feet of purple-whitemottled and baked-looking rock containing vitreous globules; this rock overlies a bed of red and white, discolored, and baked-looking sandstone, below which is volcanic rock, possibly trachytic. Similar sections exposed in the wadi show apparently altered and discolored sandstone beds between layers of volcanic rock. There was opportunity for only a very brief inspection of this occurrence, which may represent either Cretaceous sandstone altered by dikes of the Aden Trap Series (the strata dip, so inclined dikes might give rise to the section seen), or sandstone interbedded with volcanic layers.

A rather similar relation between volcanic rocks and Cretaceous sandstone was seen 8 miles north-northwest of Ash Shațt, near the Yemen border. Here sandstone and volcanic rocks form an apparently uniformly strati- 
fied series dipping $45^{\circ}$ in a direction of $220^{\circ}$. Quartzitic sandstone grades downward into 3 feet of altered purplish sandstone, which is followed by a 6 -foot-thick dike of silicic porphyry above a 20 -foot-thick sandstone horizon. Further unidentified volcanic rock underlies the sandstone. Petrographic examination of specimens of sandstone from near the contact with volcanic rocks shows the sandstone to be partly recrystallized. It is clear that at least some of the alteration of the sandstone is due to dike intrusion, but volcanic rock at the bottom of the series may represent lava. Faulting again largely obscures the stratigraphic relationships in this locality.

Aerial photographs of the Ash Shațt area show Cretaceous sandstone resting unconformably upon basement rocks and dipping about $15^{\circ} \mathrm{SW}$. Strike faulting has resulted in a series of small cuestas with volcanic rocks covering lower slopes and valley bottoms. It appears that volcanic layers may be interbedded with Cretaceous sedimentary rocks but it is difficult to verify that this appearance does not result from repeated faulting. Sandstone and volcanic rocks are cut by numerous dikes which in this locality are steeply inclined nearly at right angles to the dip of the sediments.

In summary, field observations show that volcanic rocks are underlain by the greater part of the Cretaceous sedimentary succession, but it is possible that volcanic rocks are interbedded with the uppermost Cretaceous strata.

Some 5 miles to the north-northeast of $\mathrm{Al}$ 'Anad, Jurassic fossiliferous limestone is overlain by Cretaceous sandstone, the beds striking northwest and dipping at about $20^{\circ} \mathrm{SW}$. The sedimentary rocks are separated from dominantly basaltic downdropped volcanic rocks to the northeast by a normal strike fault. To the southwest, volcanic rocks overlie Cretaceous sandstones. In the locality of Jabal al Munif intrusive granite, at least in part of peralkaline riebeckitic type, appears to postdate both sedimentary and volcanic rocks. This conclusion is based on field observations and the study of aerial photographs. To the southsoutheast of Jabal al Munif, apophyses and bands of granite are invasive into volcanic rocks, and numerous granitic dikes extend into and cut the volcanic rocks. The Jurassic limestone at a locality about $1 \frac{1}{2}$ miles north-northwest of Jabal al Munif is similarly penetrated by a band of granitic rock, and contact metamorphic effects are recognized. In the area to the south and southwest of Jabal al Munif, granitic bands, between 15 and 60 feet thick, alternate with volcanic rock. Many of the silicic bands are of light-colored microgranite. The whole assemblage is cut by later mafic and silicic dikes.
The alkaline granite of Jabal al Munif is distinguished from earlier granite exposed to the west of the $\mathrm{Al}$ Musaymir road some 2-3 miles northwest of $\mathrm{Al}$ 'Anad. Here Cretaceous sandstone rests upon the granite.

\section{AGE AND ORIGIN}

On the evidence available from the W.A.P., it is clear that volcanic rocks of the Trap Series are younger than the bulk of the Cretaceous sedimentary rocks of Nubian type. In Yemen, rocks of the basaltic trap series were stated to form interbedded layers in Cretaceous strata in the Southern (and Western) Highland rim (Rathjens in Wissmann and others, 1942). It is possible, therefore, that this is also true in W.A.P., where numerous dikes associated with the Aden Trap Series cut Cretaceous beds. In Yemen, Geukens (1960) recorded deposits interstratified with trap rocks, some of which yield freshwater fossils of Tertiary age. No Tertiary deposits other than late terrace deposits are known in W.A.P., but it is very probable that the bulk of the Aden Trap Series is of early Tertiary (Paleocene?) age. In summary, the Aden Trap Series is tentatively regarded as of Late Cretaceous to early Tertiary age. The alkaline granite of Jabal al Munif, intrusive into volcanic rocks, is considered to be of Tertiary age.

Aerial photographs of the Aden Trap Series show ash cones and volcanic vents in several areas, for example, between Al 'Anad and Aḍ Dāli'. These have also been seen in Yemen. In degree of weathering and reduction, the vents and cones contrast with the fresher and more clearly marked ash cones and craters of the later Aden Volcanic Series. In Yemen Wissmann (in Wissmann and others, 1942) recorded eruption fissures, many of which are alined along directions parallel to the Red Sea axis. In W.A.P., many of the dikes in the volcanic rocks follow this direction, and some are apparently intruded along fault planes. Thus, eruption fissures may also have followed similar fracture planes.

\section{GENERAL COMMENTARY}

The Aden Trap Series exposed in the most western region of the Aden Protectorate is part of an extensive elongate outcrop of volcanic rocks associated with the Red Sea and Abyssinian rifts. Evidence from the Aden Protectorate and from neighboring regions suggests that this mainly Tertiary vulcanism was initially expressed in dominantly mafic basaltic lavas; subsequently the effusives became more silicic; trachytic and rhyolitic flows resulted, with obsidian and rhyolitic obsidian, and interbedded tuff, as exemplified in the Ghayl Barbar area of Aden. Basaltic rocks are not, however, entirely absent in this assemblage.

It is reasonable to suppose that the alkaline granite intrusive at Jabal al Munif, Al 'Anad, which appears to 
cut dominantly basaltic volcanic rocks, was emplaced during this same phase of intermediate to silicic vulcanism. As noted, granites of apparently comparable age (Eocene?) have been reported in Yemen (Geukens, $1960)$; and in a postscript to his contribution Lamare (1930) recorded that petrographic examination of rocks from the area between Al Hudaydah and San'a', Yemen, revealed sodic granite and sodic microgranite.

Following the phase of silicic effusion there occurred a period of dike intrusion; the majority of the dikes are of doleritic and basaltic composition. Dikes (of this phase?) cut the alkali granite at Jabal al Munif, and it may be that they are of later Tertiary age.

Although the volcanic rocks of the later Aden Volcanic Series are in appearance and in topographical relations clearly distinguishable from the trap series, they seem to be magmatically part of a continuous series. The rhyolitic and trachytic rocks exposed in Aden Colony, which seem to have preceded the basaltic flows, may represent a continuation of the phase of silicic vulcanism of the trap series. Thus there seems to have occurred a cycle of effusions commencing and ending with dominantly mafic magma.

The evidence from Aden Protectorate and neighboring regions points to an alkalic olivine basalt association. Olivine basalts with alkalic affinities are known from continental areas, including the east African rifts, but in Aden Protectorate phonolites have not been recognized. The conditions which tend to be characteristic of the alkalic olivine basalt association, that is, crustal stability and faulting rather than folding or orogeny, are satisfied in the Aden region. But tholeiitic basalts are also characteristically found in a nonorogenic continental environment, and the quasihorizontal extensive flows of Aden might well be identified with plateau or flood basalts. Against this, however, it must be recalled that evidence for other than fissure eruptions has been found and that regional flooding of alkalic basalt is known in Palestine and Syria.

In summary, such evidence as is available favors the assumption of an alkalic olivine basalt association.

The dominance of olivine basalts in volcanic provinces argues a magma of corresponding type as the parent of derived rocks. This opinion may be said to be currently orthodox. A process of magmatic differentiation involving fractional crystallization is also strongly supported.

The association of vulcanicity with the east African rift system, with the west Arabian (Red Sea) and Levantine rifts, and with rifting in other regions is well known. Although volcanic rocks are absent in certain stretches, such as Lake Tanganyika, and the degree of development is generally variable in other parts of the rifts, the causal relationship is clear. The mechanism of rifting, connected with the basin-and-swell structure of Africa as a whole (Dixey, 1956a) is the subject of much discussion, but there is a large measure of agreement that the linear tectonic features involved (geosutures) are of great (primordial) age and great depth. These extensive fracture zones were subject to a recrudescence of activity at intervals throughout geological time.

Activation of the Red Sea-Ethiopian rift zone may have been accompanied in the early stages by eruption of basalt of deep-seated simatic origin. This suggests activity along the fracture zone in at least early Tertiary times. This dominantly basaltic effusion preceded further movement along the rift zone, for rocks of the Aden Trap Series were affected by faulting mainly of northwest trend. Girdler (1958), basing his opinions on gravity data, suggested that the intrusion of basaltic material into a crack along the present center line of the Red Sea caused subsurface movements which originated rift faulting along the margins of the sea, and that formation of the (present) wide fault trough is a collapse effect ultimately due to movement of igneous material into the fissure. He noted that stratigraphical work in east Africa has shown that rift faulting has repeatedly terminated periods of volcanic extrusion; he included tensional effects in his account of possible mechanisms.

It is possible that at a later date subsidence contributory to the formation of the Red Sea trough lowered crustal material to anatectic zones, and that this, combined in some way with magmatic differentiation, resulted in the eruption of alkali-rich volcanic and granitic rock. Thus it may be that the alkali granite exposed at Al 'Anad and elsewhere does not form part of a continuous granite series, but may be derived from a relatively shallow magma basin. Eruption of this alkali-rich phase may be of later Tertiary (Oligocene?) age.

\section{DIKE ROCKS}

Dike rocks of three main classes are recognized in the Protectorate, namely:

1. Dikes cutting basement rocks up to and including the intertectonic igneous rocks. Dikes of this class show a moderate degree of metamorphism of mainly dynamic type. They were not involved in the main period of regional (dynamothermal) metamorphism. Their age is considered to be later Precambrian.

2. Dikes showing no sign of deformation, which are therefore considered to postdate the widespread phase of dynamic metamorphism of late Precambrian date. Dikes of this class cut metasedi- 
mentary rocks of Wādī al Ghabar and posttectonic plutonic intrusions, but they are not known to cut Jurassic or later rocks. Their age is tentatively regarded as early Paleozoic.

3. Dikes associated with the Aden Trap Series in the southwest of the Protectorate. These are unmetamorphosed. They may cut Jurassic and Cretaceous sedimentary rocks, and lavas and pyroclastic rocks of the trap series. They do not cut postlower Miocene basalts. They are referred to as post-Jurassic dikes.

\section{PRECAMBRIAN DIKES}

Precambrian dikes cut rocks of the Aden Metamorphic Group and associated syntectonic granites in many localities, for example, east of 'Awābil and in Wādī Raybān, Wādì Ahwar, and Wādì Gharīsh. Dikes of this class are particularly numerous in the Mukayrās-Khawrah region where they mainly postdate mafic and granitic intrusions of the intertectonic group; in several places they show chilled margins against the granite. Andesitic dikes of the Mukayrās pass contain inclusions of intertectonic dioritic rock.

The obvious association of numerous dikes with the plutonic intrusions of the Mukayrās-Khawrah area, where both plutonic and hypabyssal rocks show conspicuous deformation effects, suggests a marked phase of dike formation following intertectonic plutonic intrusion. The presence of partly digested andesitic dikelike bodies in the Mukayrās granite, which form interrupted traces along a uniform strike direction in the granite, may suggest a phase of dike intrusion that followed mafic plutonic intrusion but preceded granite intrusion. In general, dike intrusion probably occurred intermittently in Precambrian times. Only those rocks subsequent to the main regional metamorphism were recognized as dike rocks in the authors' rapid reconnaissance. Many of the aplitic and microgranite dikes are thought to be associated with phases of granitic invasion.

Precambrian dikes comprise varied lithological types including basalt, dolerite, andesite and andesite porphyry, mafic lamprophyre, quartz porphyry, porphyritic granophyre, and felsite.

The thickness of the dikes ranges from 3 to 150 feet; a 150-foot-thick doleritic dike cuts granite some 12 miles north-northeast of Mukayrās. Data on strike trends are given under "Structure." Dikes of pegmatite and feldspathic rocks are referred to under "Granitic rocks."

The petrography of representative dike rocks is illustrated in the following examples.

A specimen of altered dolerite from the Mukayrās locality (A102) is composed of augite, calcic plagioclase, and large plates of iron oxide minerals. Augite is partly replaced by green fibrous amphibole transitional to chlorite, and plagioclase is epidotized. The ophitic relationship between augite and plagioclase laths is clearly seen. Evidence of stress is provided by bent pyroxenes. The rock appears to have been subjected to incipient greenschist metamorphism.

A dike of altered gabbro from Thirah (Lawdar) similarly shows incipient transition to a greenschist assemblage. The original ophitic texture is partly preserved, but pyroxene is converted to actinolitic amphibole, and plagioclase is albitized (A96).

A specimen of altered porphyritic granophyre from a dike 3 miles north of Mukayrās (A104) shows phenocrysts of perthitic potassic feldspar, as much as $5 \mathrm{~mm}$ long, and phenocrysts of epidotized plagioclase in a groundmass of feldspar, quartz, epidote, and chlorite. Quartz is full of shatter cracks. The groundmass may possibly be recrystallized.

In the Khawrah district silicic and mafic dikes showing moderate metamorphism include altered dolerite and granophyric microadamellite.

A dike cutting schists of Wādi Gharīsh is composed of slightly deformed uralitized dolerite or microgabbro, and contains basic plagioclase laths as much as $4 \mathrm{~mm}$ long. Much of the pyroxene is converted to uralite showing deformation effects and passing marginally to actinolite. Deformation is also seen in slightly bent feldspars.

\section{LOWER PALEOZOIC(?) DIKES}

Dikes of dolerite, aplite, and microgranite which cut metasedimentary rocks of Wädi al Ghabar and posttectonic granites at Nişāb, Șa'īd, and Burūm show no sign of deformation, and where sedimentary rocks overlie granites cut by these dikes, the dikes do not penetrate the Jurassic and later rocks. Dikes of this class appear to represent the last phase of intrusive igneous activity in the eastern part of the Protectorate. They are clearly pre-Jurassic and their probable connection with the later phases of igneous intrusive activity leads to the suggestion of an early Paleozoic age. Posttectonic granites of several areas have been dated by radioactivity methods as being of this age.

\section{POST-J URASAT DIKES}

Post-Jurassic dikes associated with the Aden Trap Series, are described on page C44. Dikes of this class have been recognized cutting basement rocks in Wādī Dār, southeast of Al Kirsh, where they trend west-northwest across basement foliation strike. It is possible that dikes of unmetamorphosed andesite and dolerite cutting metamorphosed basement rocks at Jabal ath Thaniyah may also be of this class. In 
general, however, post-Jurassic dikes appear to be restricted to the southwestern part of the Protectorate, where they are commonly seen to cut Cretaceous sandstone, as at 'Awābil. Dikes of varied composition also cut the alkaline granite of Jabal al Munif, Al 'Anad, which is considered to be of Tertiary age.

\section{SEDIMENTARY ROCKS}

In the Western Protectorate, sedimentary rocks are mainly confined to an east-northeast- to east-trending belt, averaging 20 miles wide, between lines running northward from Aden and from Ahwar: faulted sedimentary rocks mark the western margin of the main basement block, and restricted outliers occur at $\mathrm{Al}$ Mahfid and elsewhere in the basement-rock areas. Sedimentary rocks are also exposed in salt domes of the Ramlat as Sab'atayn.

\section{JURASSIC}

The oldest exposed sedimentary rocks are Jurassic in age and rest with well-marked unconformity on the weathered surface of the basement rocks. The sequence exposed includes the Upper Middle, and possibly Lower Jurassic, and was first named by Lamare (1930), as follows:

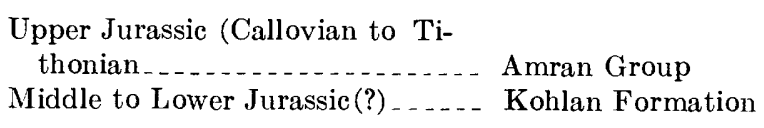

\section{KOHLAN FORMATION}

The Kohlan Formation is lithologically rather uniform, comprising light-colored sands, sandstones, and marls together with pebbly and conglomeratic basal layers incorporating recognizable fragments of basement rocks. There is a gradational contact with the Upper Jurassic member, arenaceous beds passing through sandy limestones and gritty marls to limestones of Callovian to Oxfordian age. No fossils or plants have been reported from the Kohlan Formation either in the Yemen type section or in the Eastern Protectorate where the formation is more extensively exposed.

\section{AMRAN GROUP}

The Amran Group has been subdivided (Beydoun, 1960), as follows:

Coastal area
Naifa Formation $\ldots \ldots$ Nalt domes
Madbi Formation........

Shuqra Formation Shuqra Formation(?) unexposed

The Amran Group is of variable facies and thickness, the latter due partly to erosion. In coastal areas it is a marine succession of limestones and marle, the neritic, shallow-water facies of the Shuqra Formation passing upward into the more open sea deposits of the Madbi Formation and terminating again in shallow-water sandy beds of the Naifa Formation.

Inland, among Jurassic strata exposed in the various salt domes, the Shuqra is not seen but is presumed to be present, the lowest visible beds being evaporites of the Sabatayn Formation, which is considered to be equivalent to the coastal Madbi Formation.

The Naifa Formation is of similar facies throughout, in both coastal and inland-sections, and represents the northward spread of open-sea conditions.

A section of the Shuqra Formation capping the basement rocks was examined at Al Mașanni', Abyan district; it consisted of about 230 feet of well-bedded gray limestones, veined with calcite, and thin marls.

Fossils identified by the British Museum (Natural History) included the following: Gryphaea costellata (Douville), Ceratomya sp. (possibly C. wimmisensis (Gillieron)), Modiolus imbricatus (J. Sowerby), Brachidontes (Arcomtilus) laitmairensis (de Loriol), Lima (Plagiostoma) sp., Limatulas sp., Sphaeriola? sp. (possibly S. madridi (d'Archiac)), and Globularia cf. $G$. chauviniana (d'Orbigny). On the basis of Gryphaea costellata, the most useful species for correlation, a Bathonian or Callovian age is assigned to this assemblage.

Other specimens taken from Al Mașāni' included: Daghanirhynchia daghaniesis Muir-Wood and varieties, Bihenithyris barringtoni Muir-Wood and varieties, and Bihenithyris weiri Muir-Wood. These species resemble the fauna, described in 1935 by Muir-Wood, from the former British Somaliland and are taken to be of Callovian age.

At Bilh, near Al 'Anad, a 230-foot section of wellbedded dark gray limestones and thin marls, capping a south-dipping basement block, yielded specimens of Isastraea sp. This is a well characterized species that appears to be new and to be allied to I. kosodeensis Eguchi from the Upper Jurassic limestone of Japan. According to the British Museum (Natural History) no definite age can be assigned to it, for the range of the genus is Middle Jurassic and Cretaceous, but a Late Jurassic age is probable. A more complete faunal assemblage from the Shuqra Formation has been described by Hudson (1954), from a locality near the town of Shuqra.

The Madbi Formation succeeds the Shuqra Formation and occurs in all Jurassic sections unaffected by erosion. It consists of a series of marls, many of which are gypsiferous, with scattered beds of gypsum, and thin rubbly fossiliferous limestones. Its lower contact may be locally disconformable as in Wādī Gharīsh (Beydoun, 1960) but the upper contact is conformable 
and locally gradational. From the fossil evidence, a Kimeridgian áge is indicated.

The Madbi Formation is considered to be equivalent to the Sabatayn Formation, as seen in the inland salt domes, on the basis of the evaporites, doubtful fossil evidence, and the presence in both areas of the overlying Naifa Formation; evidence from eastern Yemen also supports this (Geukens, 1960).

The Sabatayn Formation consists of an evaporite series with interbedded shales and gypseous marls, and, from the top down, has been subdivided (Beydoun, 1960) into the Ayadh (M'qah), Layadim, and Shabwa Members. The base is not exposed. Between 265 and 920 feet of the various members is exposed in the salt domes which occur in the 'Iyādh area of Hayd al Milh (lat $15^{\circ} 05^{\prime}$ N., long $46^{\circ} 49^{\prime}$ E.), in the Shabwah area (lat $15^{\circ} 22^{\prime}$ N., long $46^{\circ} 49^{\prime}$ E.), at Shabwah itself, Milh Kharwah, and Milh Maq'ah. In the Ramlat as Sab'atayn about 40 miles northeast of Baybān is the Layadim dome.

The Shabwa Member crops out in all the salt domes; its base is not exposed and it reaches 100 feet in thickness at 'Iyãdh. It is composed of gray, laminated shale, in places folded and contorted, with inclusions of gypsum and marly materials. That it is conformable with the overlying member demonstrates the depositional nature of the salt.

The Layadim Member consists of bituminous black paper shales with bands and veins of marl and salt. At the Layadim dome, massive salt is overlain by varicolored shales, bituminous in part, and gypsiferous beds. Toward the crest of the dome, salt is interbedded with fragments and blocks of contorted gray paper shales having thin lignite bands. Well-formed salt crystals are found lining fractures in brecciated shale and as stalactitic deposits under cliff faces, and in vugs. In the Shabwa dome, abundant estheria and spongistroma, together with the fish Anaethaelion, suggest a Late Jurassic age for this member.

The Ayadh Member consists of marly and bituminous limestone with limestone and interbedded gypsum. It rests unconformably on the Layadim Member and is of variable lithology and thickness, reaching 750 feet at 'Iyādh; it grades laterally into the M'qah Member, which is developed at the Milh Maq'ah dome as about 500 feet of coarse green ripple-marked sandstone containing plant remains, shaly limestone, and gypsum.

The Naifa Formation, as seen in the 'Iyādh salt dome, consists of thin-bedded porcellanous limestones with platy dolomites and marly layers. It is apparently conformable with the underlying Ayadh Member. At 'Iyādh one ammonite, Barriesella sp., of probable Tithonian age has been recorded. At other salt domes the Naifa Formation has been removed by erosion.
At Săfir, on the eastern border of Yemen about 12 miles southwest of Jabal ath Thaniyah, a salt dome has been described by Guekens (1960). As in the Layadim dome, the salt is folded and contorted; it is flanked by bituminous and marly shales which yielded pollen and spores of Classopollis reclusus (Theigart), Ephadra strobilacea, Gleicheniidites feronensis (Delcourt and Sprumont), Monosulcites sp., and Inaperturopollenites sp., of Late Jurassic age. Those beds are succeeded by about 160 feet of gypseous shales, sandy shales, and limestones. The arenaceous and gypseous beds may be correlated with the M'qah Member; the salt and bituminous shales correspond to the Shabwa and Layadim Members of the Sabatayn Formation This confirms the western extension of the basin in which the evaporite rocks of the Sabatayn Formation were deposited.

\section{REGIONAL CORRELATION}

In Yemen, Geukens (1960) described an unfossiliferous fluviolacustrine and deltaic series, that occurs between the eroded surface of the basement rocks and the upper fossiliferous Jurassic beds, and correlated it with the Kohlan Series as named and described by Lamare (1930). Overlying the Kohlan Series or resting directly on the basement rocks is a fossiliferous series of well-bedded limestone, with thin shales and marls, whose faunal assemblage is of Callovian to Oxfordian age; this series was mapped by Geukens (1960) and was correlated with the Amran Group of Lamare.

A series of transitional beds which are variable in lithology and thickness overlie the Amran Group, as noted by Geukens. In some localities the beds are absent, and Cretaceous sandstones rest directly on the basement rocks. In southwest Yemen the transitional beds are 500 feet thick, consist of shales and gypsum, and elsewhere, as in the southeast, contain limestone and marl. On the basis of the gypsum content, a correlation was made by Beydoun (1960) with the Sabatayn Formation of the Aden Protectorate. Outside this evaporite basin, limestones of more open sea deposition were correlated with the Madbi Formation. No beds similar to the Naifa Formation are present in Yemen; thus, dry-land conditions or emergence in that area are indicated.

\section{CRETACEOUS}

Cretaceous beds are not extensively exposed in the Western Protectorate. In general, the beds vary in thickness and lithology from west to east and show several well-marked unconformities. They rest unconformably on Jurassic beds (fig. 17) - or directly upon basement rocks- the contact being marked by 


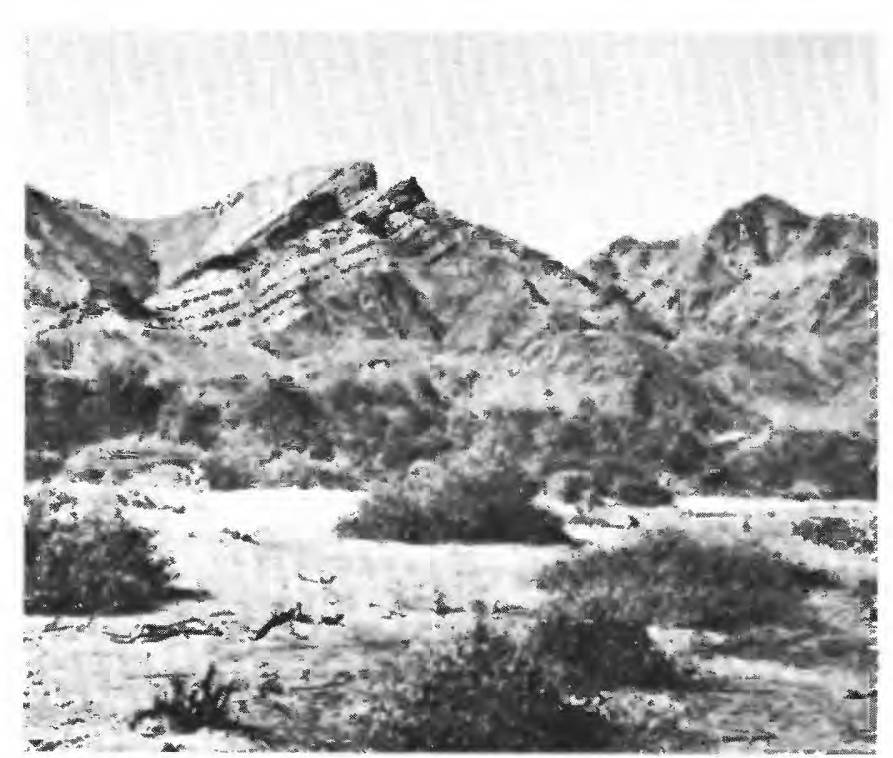

Figure 17.-Cretaceous sandstone overlying Jurassic limestone, Wādī Raybān.

a zone of conglomerate. They fall into two lithostratigraphic groups, subdivided and named by Beydoun (1960), as follows:

\begin{tabular}{|c|c|c|c|c|}
\hline Age & & Western Province & & Eastern Province \\
\hline \multirow{2}{*}{$\begin{array}{c}\text { Senonian (probably } \\
\text { Campanian- } \\
\text { Maestrichtian) }\end{array}$} & \multirow{5}{*}{ 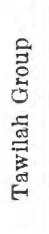 } & \multirow{2}{*}{ Mukalla Formation } & \multirow{5}{*}{ 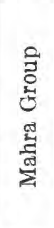 } & Sharwayn Formation \\
\hline & & & & Mukalla Formation \\
\hline \multirow{2}{*}{$\begin{array}{l}\text { Cenomanian to } \\
\text { Albian (probably } \\
\text { including some } \\
\text { Turonian) }\end{array}$} & & \multirow{2}{*}{ Harshiyat Formation } & & Fartaq Formation \\
\hline & & & & IIarshiyat Formation \\
\hline Aptian-Barremian & & Qishn Formation & & Qishn Formation \\
\hline
\end{tabular}

The Tawilah Group is predominantly clastic with lenses of marl and limestone thickening eastward, whereas the Mahra Group is mainly a limestone-marl facies with sandstone intercalations.

In the area under description, the Tawilah Group is a varicolored succession of ferruginous locally currentbedded sandstone, siltstone, marl, and shale, with much conglomerate. Scattered lenses of limestone contain a faunal assemblage of Barremian to Maestrichtian age.

The Qishn Formation is not distinguishable from the overlying clastic deposits on the borders of Eastern and Western Aden Protectorate, but is represented farther east by fossiliferous limestones and marls. The formation rests unconformably on various members of the Jurassic sequence which was disturbed by terminal Jurassic earth movements and eroded.

Overlying the Qishn conformably is the Harshiyat Formation of Albian to Cenomanian age. It is a clastic series with predominating current-bedded sandstones, as well as marls and shales. Two fossiliferous marine limestone lenses occur in the east, the upper or Sufla Member separating the Harshiyat from the overlying but lithologically similar Mukalla Formation. The lower or Rays Member occurs within the basal clastic strata. Both these limestone members pinch out close to the $48^{\circ}$ meridian.

The Mukalla Formation is of Senonian age and lies conformably at the top of the Tawilah Group east of $48^{\circ}$ longitude, and is a varicolored sequence of clastic beds.

Regional correlation.-In Yemen the Taouilah Series described by Lamare $(1930,1936)$ was divided by Geukens into a lower or "Nubian" sandstone facies, of continental origin, and an upper Medj Zir Series, which is neritic and contains a Paleocene to Eocene fauna. In southwest Yemen the upper beds of the Taouilah Series contain trap lava sheets, demonstrating the commencement of volcanic activity contemporaneously with marine sedimentation of the Medj Zir Series in other areas.

\section{TERTIARY}

\section{PALEOCENE TO MIDDLE EOCENE}

The Paleocene epoch was marked by a widespread transgression which covered the greater part of Eastern Aden Protectorate and eastern Saudi Arabia while volcanic activity continued in Yemen and parts of Western Aden Protectorate.

A considerable thickness of calcarenites was laid down during this period, which ended with general uplift and emergence in the late Eocene time. This group of rocks, which includes some evaporite and clastic deposits has been named the Hadhramut Group by Beydoun (1960), and is present as a narrow strip west of the $48^{\circ}$ meridian.

The group is subdivided as follows:

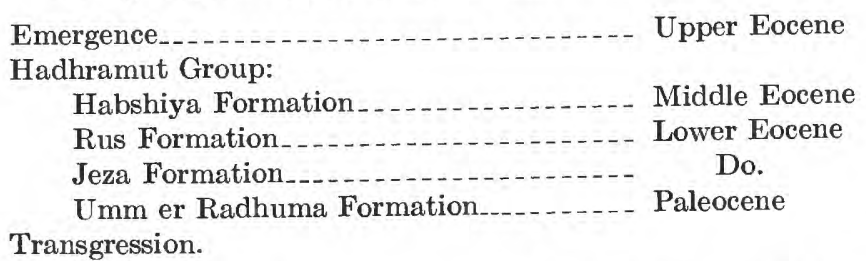

The Umm er Radhuma has been shown on fossil evidence to rest disconformably on the Cretaceous beds (fig. 18). At the type locality in the Hadhramut it consists of a basal dolomite overlain by paper shales and nodular limestone, succeeded by a thick sequence of massive dark-brown and gray commonly dolomitic limestone which is distinctive in the field. Toward the top of the formation a thick zone of nodular shaly cavernous limestone forms cliffs, and slumped sections 


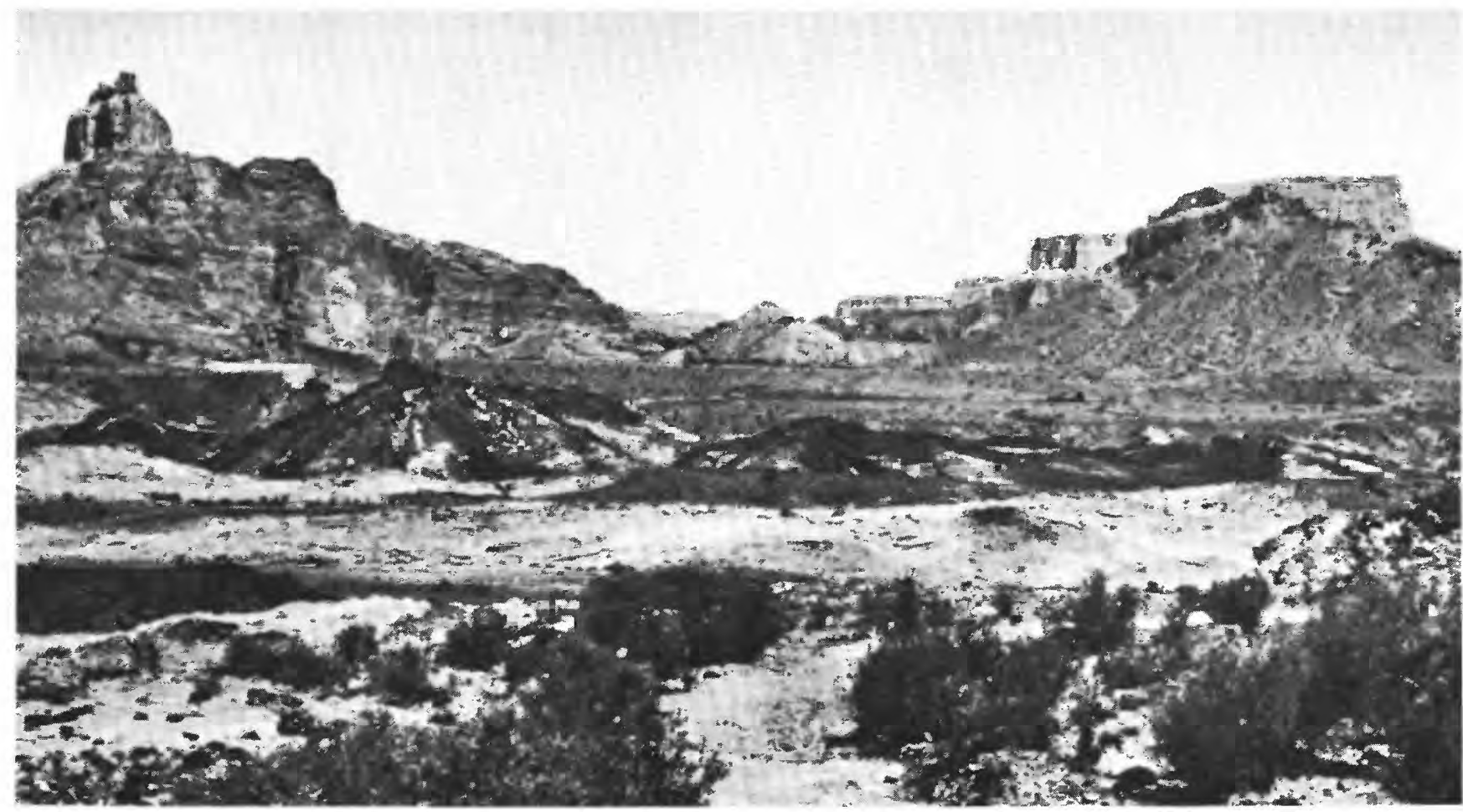

FIGURE 18.-Paleocene limestone overlying Cretaceous sandstone, 6 miles north-northeast of Al Khabr.

are common. The formation thins out in a westerly direction toward a shoreline which is presumed to lie somewhere in the Western Protectorate. It is considered to be homotaxial with the trap lavas of Yemen and the Western Protectorate border areas.

The Jeza Formation overlies the Umm er Radhuma conformably and consists of paper shale, marl, and limestone, with chert and gypsum layers present toward the top.

The Rus Formation is typically developed in Saudi Arabia, and in the Aden Protectorate consists of massive gypsum, with limestone bands and marls. These cap many of the limestone plateaus and form a distinctive pattern on aerial photographs.

The Habshiya Formation is the top member of the group and occupies a very limited area north of Mayfa ' $\mathrm{ah}$, in the region under description, and consists of yellow to pink paper shale, marl, and limestone, with a rich foraminiferal assemblage, as well as echinoids.

\section{OLIGOCENE AND MIOCENE}

The Shihr Group is a transgressive series laid down in coastal embayments and tectonic depressions after emergence of the land surface at the end of the Eocene Epoch. The group consists of limestone, marl, shale, and gypsum, and rests on a variety of older formations. The group is not represented west of $48^{\circ}$ longitude.
POST-MIOCENE

Post-Miocene deposits appear as raised beaches of various elevations and ages, and occur extensively along the coasts of the Arabian Peninsula; inland they commonly pass into the river terraces.

Other late Tertiary to Recent deposits include alluvium, loess deposits, and probably the sand deserts, such as the Ramlat as Sab'atayn.

\section{ADEN VOLCANIC SERIES}

The term "Aden Volcanic Series" is derived from Blanford's (1869) description of the "Aden Series." PREVIOUS WORK

McMahon (1883) gave petrological descriptions of Volcanic rocks collected from Aden. These included basalts, some vesicular, containing augite, porphyritic feldspar, and altered olivine; also andesites, trachytes, quartz trachytes, trachytic pitchstone, and pumice. McMahon noted that the inside of the main Aden crater presents an unbroken succession of lavas from silicic pitchstones to basaltic rocks. Silicic rocks seem to have predominated. McMahon was unable to give the order of succession of the mafic intermediate, and silicic lavas.

Raisin (1902) described rock specimens from Perim Island. All the specimens examined were volcanic. Those found in place included basalts and tuffs. 
Lamare (1930), in his discussion of post-Cretaceous vulcanism of the Red Sea and neighboring countries, proposed a division into eruptions anciennes, prior to subsidence (of the rifts and fault troughs), and eruptions recentes. The latter correspond to the Aden Volcanic Series. Lamare noted that the grouping is not clear cut and that overlapping of the two types occurs. The following notes refer to the recent eruptions.

With reference to the northern border of the Gulf of Aden, Lamare mentioned puys in the locality of Bāb al Mandab; he also mentioned Jabal Kharaz, said to attain a height of $839 \mathrm{~m}$., Jabal Sunamma (168 m.), Jabal al Birkah $(229 \mathrm{~m}$.), and Jabal Marsá. No studies of these "volcanoes" were recorded. The Aden Volcano was considered to be older than the just-mentioned basaltic puys, on the evidence of more advanced denudation. Petrographic studies by several workers between about 1874 and 1907, cited by Lamare (1930), indicated, from Aden and Little Aden, lavas of quartz-trachyte (liparite), rhyolite approaching pantellerite, comendite, and trachyte passing to andesite (trachyandesite). Quartz, trachytes may contain riebeckite. Lamare remarked that these alkaline rocks form the base of the Aden Volcano and are succeeded by basaltic and doleritic flows. Brief mention was made of volcanic rocks in the Balḩâf and Bi'r 'Alì areas of E.A.P., consisting of olivine basalt with basaltic cones of undoubted Quaternary age. A volcano in the interior of Hadramawt, Bir Barhūt, was referred to as being active at the end of the 10 th century.

Jaques (1954) gave a brief description of volcanic rocks, believed to be of very recent age, occurring at Aden Peninsula, between Shuqrah and Abswar, and near Bi'r 'Ali. He recorded thin bands of lava cutting sands of the coastal plains at Shuqrah and in the sea off Little Aden. At Aden Colony the rocks were said to be mainly of ash and tuff, and only a relatively small amount of lava is of andesitic or trachytic composition. At Little Aden, lava was said to be more in evidence and of very variable type. Jaques was unable to determine the location of vents at Aden or Little Aden and regarded the crater locality of Aden as an unlikely spot for the center of volcanic activity.

Beydoun (1960) mentioned that volcanic cones and basalt sheets are found along the coast from Aden into southeast Hadramawt, and sporadically farther east. They are probably associated mainly with the Neogene to Recent coastal faulting.

Irving and Tarling (1961) gave some description of the Younger Volcanics of the Aden Peninsula which were sampled in connection with paleomagnetic studies. The Aden Volcano is said to consist of lava flows and pyroclastic rocks intruded by trachyte plugs. The main crater is in the eastern part of the peninsula, the peak of Spion Kop being the central cone. The base of the volcanic rocks is not exposed. Their age is estimated as Pleistocene or Recent by reference to the extent of erosion and preservation of land forms. An earlier age is not excluded. In Holkat Bay (lat $12^{\circ} 46^{\prime}$ N., long $45^{\circ} 02^{\prime}$ E.) and Khusaf Valley (lat $12^{\circ} 46^{\prime} \mathrm{N}$., long $45^{\circ} 01^{\prime}$ E.), massive trachytes were sampled at eight sites. These may be plugs or possibly thick flows. An evidently intrusive trachyte plug was sampled in the Golden Mohur Bay area (lat $12^{\circ} 46^{\prime}$ N., long $44^{\circ} 59^{\prime}$ E.).

\section{DISTRIBUTION}

Rocks of the Aden Volcanic Series cover an aggregate area of approximately 1,600 square miles in W.A.P. and perhaps 120 square miles in E.A.P., to as far east as the longitude of Al Mukallā.

In the Western Protectorate, outcrops have been mapped as follows: At Perim Island in the Straits of Bāb al Mandab; in the locality of Jabal Kuwah, northeast of Hişn Murād; in the area of Jabal Kharaz; as small outcrops at Jabal al Birkah and Jabal Marsá; at Ra's 'Imrān; at Aden and Little Aden; between the coastal centers of Shuqrah and Ahwar; and extending inland as far north as Aș Șurrah.

These outcrops are mostly coastal. More restricted lava flows are distributed around volcanic centers farther inland in W.A.P. Some of these are of very small extent and are found in isolated remnant patches in wadis. The main occurrences are about 18 miles south of Nișāb, where basaltic lava rests upon basement rocks; in Wādī Abadan, 4 miles south of Al Hujayrah; and northwest of 'Ataq, where isolated outcrops of basalt, roughly elongated in a northwest-southeast direction, extend about 25 miles. The well-developed extinct crater of Al Kirsh ('Ataq) is included in this group.

In E.A.P. the largest group occurs between the port of Balbāf and Bi'r 'Alī, extending inland to a maximum of about 12 miles. Further, smaller patches of basalt occur at Karīf Shawrān, east of Bi'r 'Alī, and at Ra's Majdabah and to the north of it. Basalt flows and cobble spreads are seen in the lower reaches of Wādi Hajr, in Wādì Raymah, and also in Wādī al Ghabar. Small outcrops have been identified to the north and northwest of Jizwil. In the area of Ra's Quşay'ir, some 85 miles east-northeast of Al Mukallā, basalts appear from aerial photographs to rest upon Oligocene and Miocene Shihr beds, and flows follow valleys cut in these rocks. Aerial photographs show volcanic rocks of the Aden Series between Mușayni'ah and Sharkhāt and inland from this coastal strip. 
Aden Peninsula.-In the Aden Peninsula the volcanic rocks of Little Aden have not been examined other than on aerial photographs, which in certain localities show dark-toned (basaltic?) lava apparently overlying lighter toned (silicic?) lava.

The main feature at Aden is the extinct crater, breached (that is, denuded and reduced) on its eastern and northeastern side. The elevated rim on the southern and western circumference appears, from aerial photographs, to consist of thin beds of interstratified tuff, ash, and breccia. The quaquaversal dip of these beds, and of more peripheral lava flows which reach to the sea in many places, serves to confirm the identity of the crater. The center of the crater is floored by a dissected plateau of lava which is of trachytic type at some places, for example, in the locality of the ancient tanks, but which may possibly have a central plug of basalt.

The variety of volcanic rock types found at Aden is indicated by the data given in details of previous work. In addition, specimens taken from the northern slopes of $\mathrm{Al}$ Aineh include:

1. A fine-grained trachyte with phenocrysts of alkali feldspar set in a fine groundmass of alkali feldspar microlaths. Other feldspars show crosshatehed twinning suggestive of anorthoclase. Granules of aegirine-augite and octahedra of magnetite are abundant. Some interstitial quartz and a carbonate mineral are present.

2. A silicic volcanic rock-trachyte(?) or rhyolite. In this rock microphenocrysts of alkali feldspar, finely twinned sodic plagioclase, and aegirine augite occur sporadically. The fine groundmass is nearly indeterminate but includes colorless glass with spherulitic texture, feldspar laths, and abundant altered sodic(?) amphibole.

3. A highly vesicular porphyritic basalt. Red pseudomorphs of iddingsite suggest original olivine. Clinopyroxene and plagioclase form the mediumgrained groundmass.

4. A fine-grained basalt with plagioclase microphenocrysts. The groundmass is of calcic plagioclase, pyroxene, and magnetite. Scattered crystals of iron-strained olivine are rimmed by pyroxene.

Karīf Shawrān.-The well-preserved extinct crater of Karif Shawrann is near the coast some 21/2 miles east of Bi'r 'Ali, E.A.P. The landward lip of this crater reaches an elevation of about 300 feet above the general ground level. A saline crater lake, with a species of mangrove at the periphery, proved to have a water level corresponding to sea level, and local information indicated that tidal changes affect the lake, which must therefore be in communication with the sea. The crater walls show quaquaversal dips and are composed of tuffaceous material and ash that have a calcareously cemented crust, fractured to a mosaic pattern. The inclination of the upper slopes was measured as $24^{\circ}$; that of the lower slopes, as $13^{\circ}$. Ejected material found on the side of the cone included pebbles of olivine basalt, syenitic rock, silicic lava, gabbro, and dunite of bottle-green glassy olivine. Other less well preserved craters and cones are present in the area.

General.-Apart from the mixed rocks of the Aden Peninsula, other exposures of the Aden Volcanic Series consist of basaltic flows and pyroclastic material. The lava appears to have erupted mainly, if not entirely, from central vents, the evidence for which is well shown in cones of ash and agglomerate, many of which appear fresh and well preserved. These occur between Shuqrah and Ahwar, in the Balhâf-Bi'r 'Alī area, and elsewhere.

The largest extent of basaltic rock is that of the Shuqrah-Ahwar outcrop, where flows rest upon basement rocks or upon Jurassic and Cretaceous sedimentary rocks. The character of the basalts, here and elsewhere, varies from scoriaceous vesicular ropy lava, mixed with pyroclastic material, to massive columnarjointed rocks. Olivine is a nearly ubiquitous mineral component. At Jabal Kharaz massive dense basalt is interlayered with highly vesicular "thin-bedded" flows, weathered to a honeycomb rock.

Between Balḩāf and Bi'r 'Alī cones of red ash and cinders produce striking scenery, standing above plateau-forming lava flows (fig. 19). The flows in many places form steep-sided ridges, as though constrained to flow in channels cut in pyroclastic material or possibly alluvium, which has since been denuded. The elevation of bedrock underlying basalt in this area is not known, but it is probable that flows exceed 200 feet in thickness.

The comparatively recent age of the Aden Volcanic Series is attested by its appearance both in the field and on aerial photographs and by the topography. The flows are seen filling recent water courses and upon terraces. East of As Sawād on the Ar Rawd̦ah road, basalt caps terrace conglomerates that rest upon Cretaceous sandstone. The Wādi Rufād, 11 miles north of Jil'ah, E.A.P., an estimated 40-50 feet of columnar basalt rests upon some 100 feet of terrace deposits consisting of beds of calcareous silty clay, 1-4 feet thick, interstratified with boulders (fig. 20). The state of preservation of many of the ash cones also indicates a very recent age for much of the basaltic rock, but aerial photographs of the area between Shuqrah and Ahwar, as elsewhere, clearly show flows of differing age (fig. 21). Extrusion of lava was intermittent over a considerable period. Further evidence that basaltic flows are of 


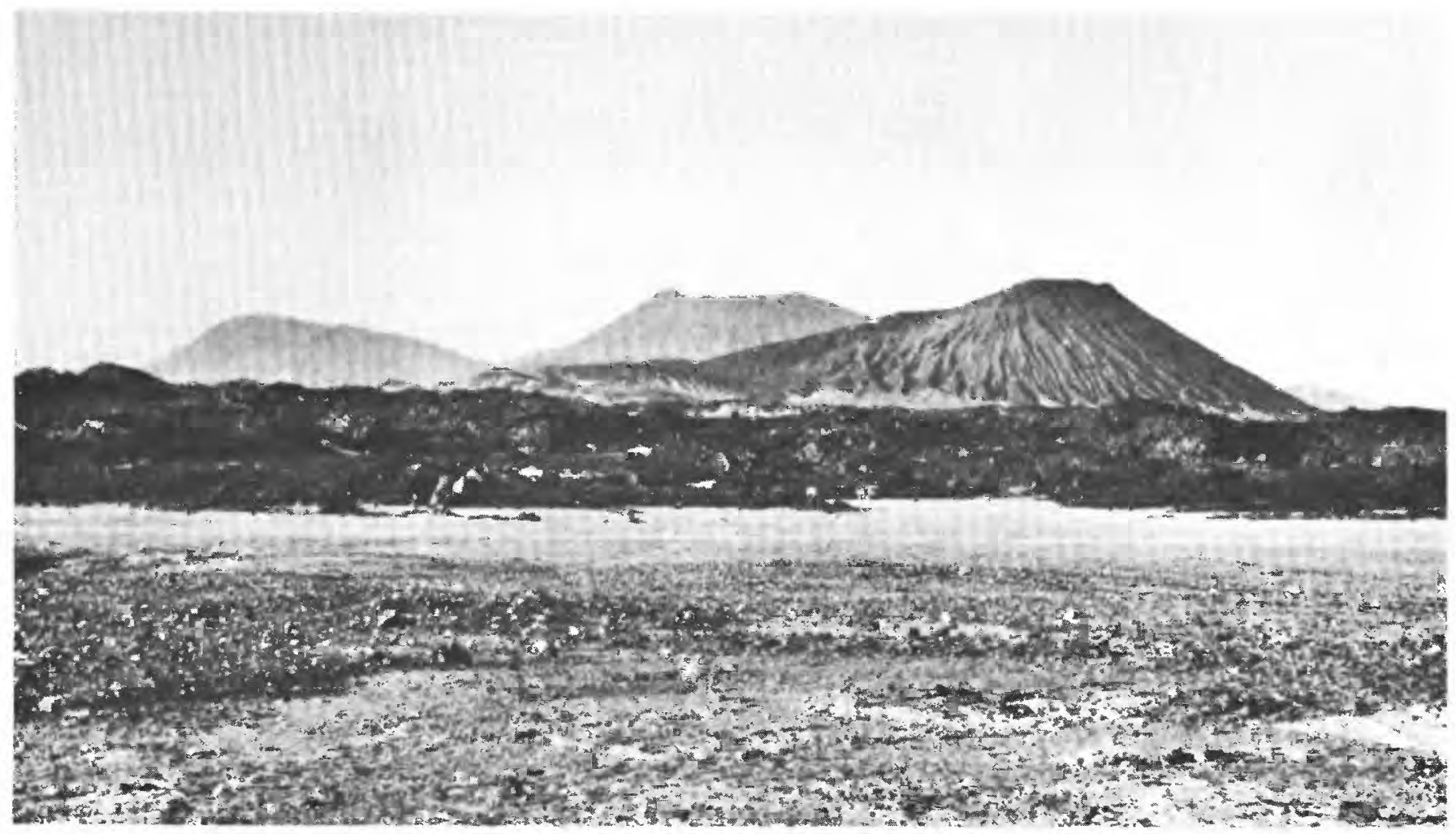

FIgure 19.-Basalt flows and volcanic cones of the Aden Volcanic Series, north of Karif Shawrān, Bì' 'Alī.

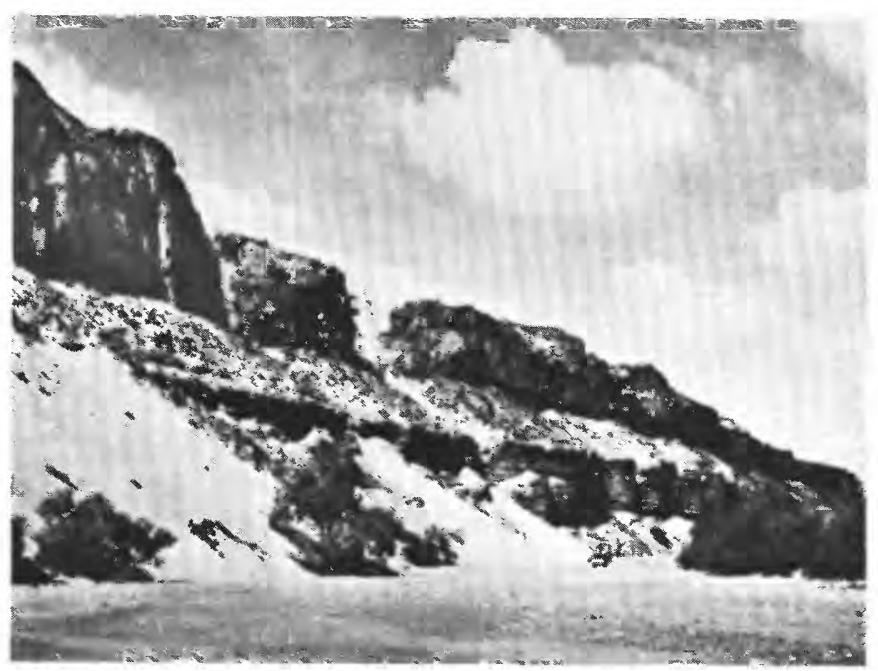

Figure 20.-Columnar basalt resting on terrace deposits, 11 miles north of Jil'ah.

differing age is the fact that no raised beaches are seen on the flows between Bi'r 'Alī and Balḩāf, whereas terraces are cut in basalt in Wādi Hajr.

As noted above, basalts appear to pierce through and rest upon Oligocene and Miocene Shihr beds at Ra's Quşay'ir; in former Somaliland Protectorate basalts of the Aden Volcanic Series rest upon Miocene
Dubar Series (Greenwood, 1960). These volcanic rocks seem clearly to be post-early Miocene, and it is concluded that the Aden Volcanic Series is of late Miocene or Pliocene to Recent age.

There is reason to suggest that the more silicic phases of eruption seen in the Aden Peninsula preceded basaltic effusions. Further support for the later date of the basalts stems from the fact that all lava flows seen elsewhere in the Aden Volcanic Series, some of which are clearly of very recent date, are of basalt.

\section{REGIONAL CORRELATION}

Volcanic rocks equivalent to the Aden Volcanic Series have been recorded in Yemen as flows of varying age, and in the remains of extinct volcanoes (Geukens, 1960; Lamare, 1930). They have also been recorded in Ethiopia (Lamare, 1930). In former Somaliland Protectorate, the Somaliland Oil Exploration Company, Ltd. (1954) noted these rocks in the Bulhar area and in the western boundary region where basaltic flows extend from the coast along the border between former British and French Somaliland. The series is dominantly basaltic, but rhyolites and tuffs occur locally, mostly near, or forming, volcanic vents.

\section{STRUCTURE}

The Protectorate is broadly divisible into three, parts namely the sedimentary plateau of E.A.P., the tecton- 


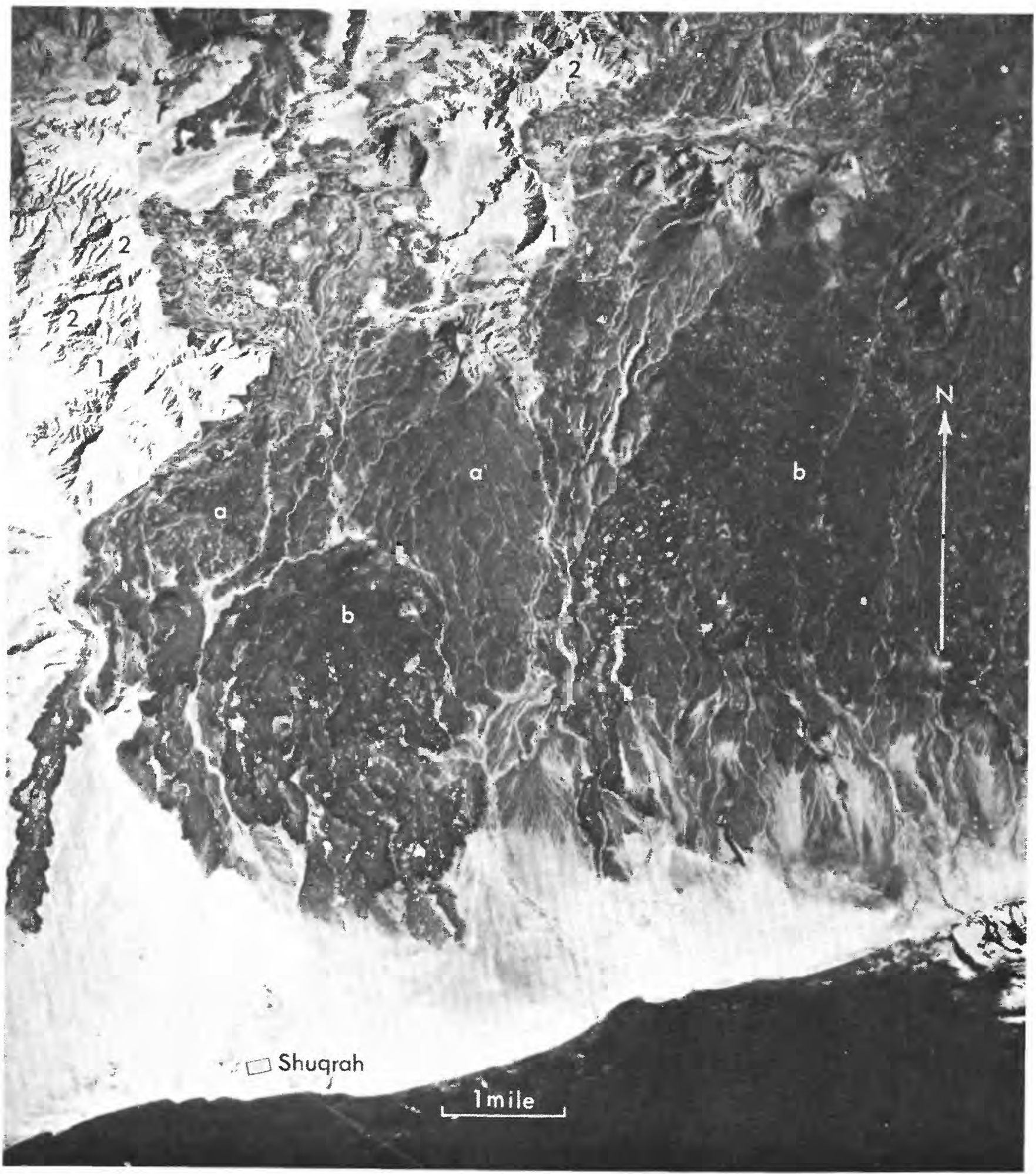

FIgure 21.-Aden Volcanic Series, north of Shuqrah. Basaltic flows rest upon Jurassic limestone (1) or upon basement rocks (2). Flows of two stages are discernible ( $a$ and b). Royal Air Force photograph. Crown copyright reserved. 
ically uplifted main basement block of W.A.P., and a structurally depressed area in the southwest mainly covered by volcanic rocks of the Aden Trap Series.

Basement rocks underwent at least two main periods of stress, with concomitant folding, metamorphism, and syntectonic granite invasion. Certainly since Mesozoic times and probably since the Early Cambrian, movements in the Gulf of Aden region have been of epeirogenic type. The Jurassic and later history is one of intermittent uplift and successive marine transgressions from an easterly direction. In Late Cretaceous and Paleocene times and again in late Miocene to Recent times, vulcanicity accompanied uplift and faulting. Eustatic movements from Pliocene times resulted in raised beaches and downcutting by wadis through thick terrace deposits.

\section{BASEMENT STRUCTURE}

BASEMENT STRIKE TRENDS

The photogeological map prepared by Overseas Geological Surveys at a scale of $1: 500,000$ provided the first plot of basement strike trends in Western Aden Protectorate. These basement strike directions cannot be shown on the Arabian Peninsula geological map at the scale of $1: 2,000,000$, but they are indicated in a somewhat generalized form on plate 1 . Some explanation is required to clarify the significance of the strike lines shown.

Fieldwork in Aden Protectorate has proved that, over a large part of the region, foliation (here used in a general sense to include schistosity and gneissose foliation) and flow cleavage are parallel with the axial planes of folds; as tight folding is very common, a general parallelism between relic bedding and foliation exists. Relic bedding can be clearly discerned in the field in many areas, so this expected parallelism can be confirmed. Numerous bands of resistant rock, such as crystalline limestone and quartzite, commonly of small thickness, facilitate the recognition of stratigraphic horizons from aerial photographs, and such marker beds are seen to strike concordantly with the foliation of other basement rocks. Thus over most of the region the lineations plotted from aerial photographs may fairly be regarded as representing the strike of both bedding and foliation. In places of significantly plunging structures, however, where marker beds are absent, it is not possible to know whether relic bedding or foliation is plotted. Also, fieldwork has shown that in some localities relic bedding is not coincident with foliation. In such places, it appears that, wherever this has been checked, foliation or cleavage is reflected in aerial photographs (and has therefore been plotted), rather than relic bedding.

In the southwestern part of the Protectorate, the overall strike trend of the basement rocks is approxi- mately northeast, with a swing to north-northeast in the area of the headwaters of Wādi Banā, west of Mukayrås. This north-northeast direction is continued in the Bayhān area, changing to north on the southern border of the Ramlat as Sab'atayn. In the main ridge of Jabal ath Thaniyah the strike is also within a few degrees of north but changes to northwest in the northern appendage of this range.

The northeast trend seen in the southwestern region of the Protectorate continues through the MukayrāsLawdar area, where the escarpment of the Kawr al 'Awādhil forms a parallel feature, and extends along, and to the west of, Wādi Durā to about the latitude of Nis̄āb.

To the northwest and east of Nişāb, an abrupt change of strike occurs, the trend here being northwest. This break is marked by minor mapped faults, but the presence of a major fault running northwest through Nișāb and linking with faults on this trend in the southeast sector of Jawl aş Șalab is suspected. The northwest strike trend is clearly expressed in a belt of steeply dipping rocks extending from near 'Ataq southeastward through As Sufāl to the 14th parallel. The strike of the basement rocks is here parallel with the major fault zone that separates basement rocks from sedimentary rocks to the east.

A strong east-west component is seen in the rather variable strike trend of the region bounded by Müdiyah to the west, by Nişāb to the north, and by 'Irqah to the east. In the east and southeast of this region the strike swings through northeast to reach parallelism with the northwest fault zone mentioned previously.

In E.A.P. the foliated rocks flanking granite and the Jibāl al Aswad range show a west-northwest strike parallel with the elongation of the range. The basement rocks of the Wädi Gharish area, although variable in detail, maintain an overall strike of about $10^{\circ}$ west of north. Metasedimentary rocks of Wādī al Ghabar strike between north and about north-northwest. By contrast, the elongate dome structure of Zulm Bā Tha'lab (older volcanic rocks), and also the basement rocks at Jabal Jahmum, Wādi Hajr, trend roughly eastnortheast.

Attention is drawn to the parallelism between the basement strike over extended areas and to the several directions of the regmatic shear pattern.

Distortion of the strike of basement rocks by plutonic intrusions is seen in the area to the south of Nişāb, in the southwestern part of the Jibāl an Nisìyin block, and in the Bayhann area. In these localities the foliation strike curves around the granite margin and suggests the advent of granitic plutons as nearsolid masses. In some places the disruptive effect upon foliation strike was minimized, where the intru- 
sions formed bodies elongated parallel with the basement grain, as at Jibāl al Aswad, and on a smaller scale to the south of 'Ataq, where mafic plutonic rock caused slight divergence of basement strike. In contradistinction to the distortion of basement strike by later plutonic intrusions, the coincidence between foliation of granitized rock and adjoining basement rock is well seen on aerial photographs.

\section{DIKE DIRECTIONS}

Many of the dikes of varied composition and age, which cut basement rocks, follow northwest and northeast directions, as in the Mukayrās-Khawrah area. In volcanic rocks of the western part of the Protectorate the northwest direction appears dominant. Although definite evidence is not available in the absence of a statistical analysis of a large number of dike directions, observations suggest that these are the preferred orientations of the majority of dikes. The northeast direction is also followed by many but not all dikes and veins of pegmatite, quartz, and feldspar.

Other main directions followed by dikes include north-northwest, north-northeast, and west-northwest. Dikes trending north and east also occur, and it may be significant that these appear to be the preferred directions of dikes cutting later granites.

\section{JOINT DIRECTIONS}

Joint directions in granitic rocks are similar to those noted for dike intrusion, with the additional eastnortheast trend seen in the Sacid granite. Major north- and east-trending joints were seen in granitic rocks of Mukayrās, Mūdiyah, Nișāb, Jibāl an Nisīyin, and Jibāl al Aswad.

Apart from fracture cleavage, which affects basement rocks of all areas, more widely spaced fracture planes approximately at right angles to foliation are also common.

\section{MAjJOR FOLD STRUCTURES}

The study of aerial photographs of the basement rocks of the Protectorate shows that these have undergone intense and complicated folding and contortion, the unravelling of which would entail much detailed work. In the reconnaissance of a large region this could not be done, and it is possible only to point out some of the more obvious structural effects, and to note the opportunity for further work in this territory.

$A$ fold structure of considerable significance occurs some 10 miles west of Yashbum near the eastern margin of the main basement-rock area, which is delimited by a major zone of faulting trending northwest. This is an asymmetrical synclinal fold or synclinorium in which the rocks forming the limbs are involved in subsidiary close folds. The structure has a curving axis which, in the northern, more clearly defined part, plunges to the south-southwest. The northern continuation of this structure is obliterated by the invasion of granitic rock but the attitude of the exposed structure suggests that the axis of folding continued to swing through a north direction to become parallel with the fault zone to the east. Steeply dipping rocks of the east flank strike parallel with the fault zone, and the general disposition of the fold suggests reorientation of an original east strike by compressive stress transmitted through sinistral transcurrent movement along the fault zone referred to. This is supported by conditions to the south of the synclinal area where, near Al Mabfid, basement strike, which is mainly east farther to the west, similarly swings through a northeast direction before becoming parallel with the fault zone.

Folding occurs mainly on east axes in the basement rocks over an area extending to about 65 miles northwest and north-northwest of Ahwar. Synclinal folds with eastward plunge are mapped in the area some 16 miles southeast of Aș Șurrah, and 17 miles southsoutheast of Khawrah.

In the main basement block, west of a line between Shuqrah and Mukayrās, the photogeological mapping shows large-scale folds, axes of which trend mainly northeast. A large synclinal fold plunging to the southwest is indicated about 15 miles southwest of Mukayrãs. The zone of folding on northeast axes is continued to the northeast of Lawdar along a line parallel with Wādi Durā. The complicated folding here may be the result of large-scale drag effects connected with transcurrent faulting along the line of the wadi, but this has not been substantiated.

\section{MINOR FOWD STRUCTURES}

During the field reconnaissance there was little opportunity for the study of minor fold structures. Brief observations of some of these folds are recorded here.

In the main Jabal ath Thaniyah range, several asymmetric plunging folds were noted. In one of these, developed in crystalline limestone, the axis trends north-northeast and the fold plunges steeply to the north-northeast. The axial plane dips steeply in a direction of $120^{\circ}$. The fold shows a steeply dipping eastern $\operatorname{limb}$, whereas the western $\operatorname{limb}$ dips at a moderate angle. Other folds in this range appear to have the same orientation.

Basement rocks in Wādī Ahwar show particularly marked minor folding and plications about axes trending $310^{\circ}$ and plunging southeastward at low angles (fig. 22). In basement rocks to the northwest of 'Irqah, feldspathic bands show minor folds along axes trending 


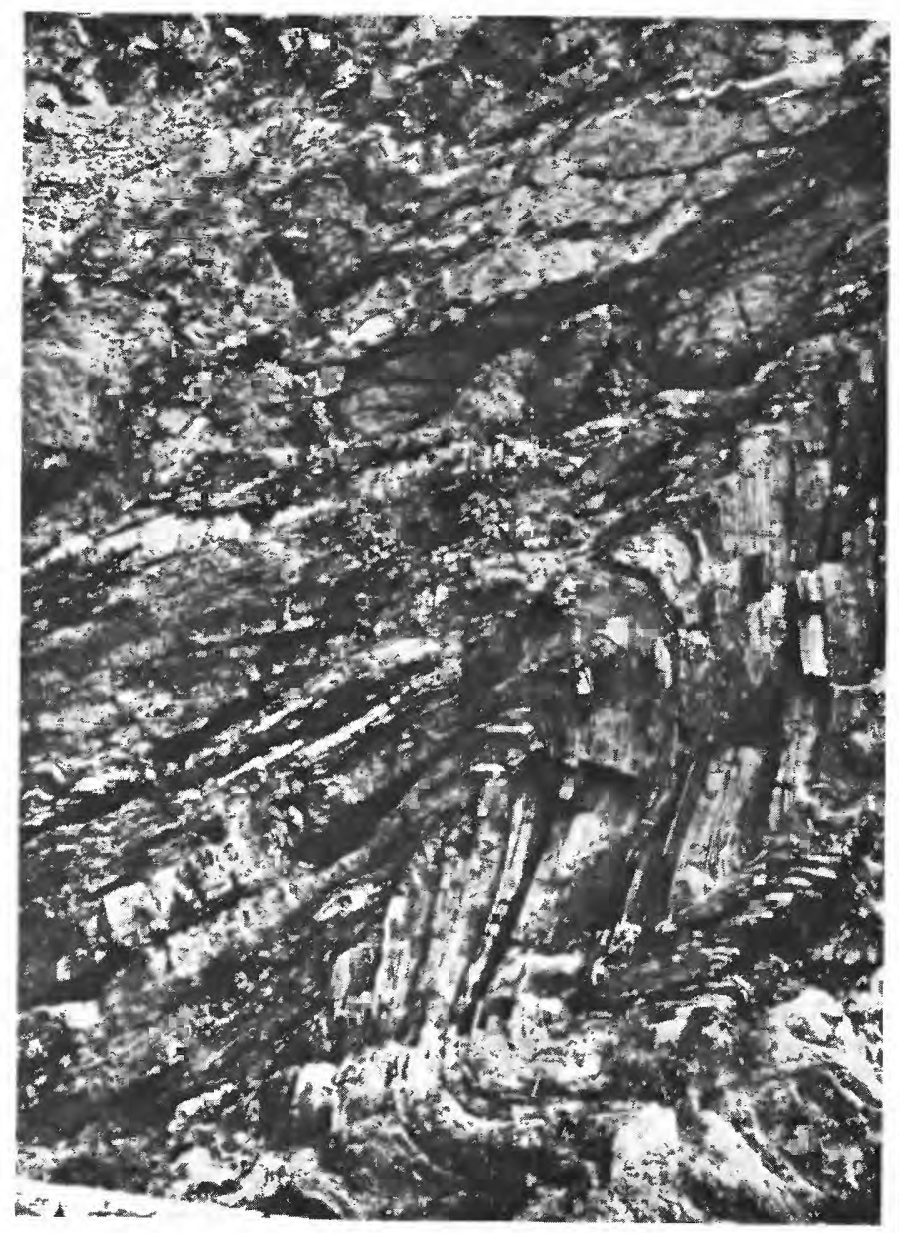

Figure 22.-Folds in basement rocks, Wādī Aḅwar.

$340^{\circ}$. At Ji'ār, in the Abyan district, basement rocks below unconformable Jurassic beds show small-scale folds with axes trending $310^{\circ}$ and plunging as in Wādī Ahwar.

The trend of the fold axes as observed at 'Irqah, Ahwar, and Ji'ār, agrees with the strike trends plotted from aerial photographs, and thus confirms the reliability of data from the photographs. Aerial photographs show great variation in the trends of small-scale folds from one locality to another and this is attributed to differential movement between faulted basement blocks.

\section{GENERAL}

Over much of the basement-rock area, tight isoclinal folds are seen in steeply dipping belts, such as that running southeast from 'Ataq through As Sufāl, and in the belt parallel with Wādi Durā in the Khawrah district. The dip of foliation and relic bedding planes in the 'Ataq-As Sufāl belt ranges between $65^{\circ}$ and vertical; in Wādi Durā dips of $60^{\circ}$ to vertical were measured. In many other areas, dips between $45^{\circ}$ and vertical occur. In belts of steep dip, the dip direction may vary along the strike, indicating overturning. The folding appears to be of similar, as opposed to concentric, type.

In some areas, as between Aș Șurrah and Nūsah, folds of open type were seen in which dips on the fold limbs range from $15^{\circ}$ to $30^{\circ}$. During the survey no obvious variation in the distribution and thickness of competent and incompetent strata was noted between areas of tight and open folding, and no explanation for variation in fold type can be given beyond the suggestion that this may be related to stress differences controlled by the alinement of ancient shear directions now marked by faults. Open folds tend to be associated with faults of mainly east trend, whereas some tightly folded belts are associated with, and run parallel to major northwest- and northeast-trending faults.

Many basement rocks give evidence of at least two major periods of stress, one associated with dynamothermal metamorphism and a later one associated with metamorphism of mainly dynamic type. Some of the evidence for two or more periods of stress is derived from the fact that the strike of foliation and relic bedding is opposed in several localities. In the $\mathrm{Al}$ Musaymīr area, relic bedding in a quartz-biotite schist strikes at $320^{\circ}$; the foliation strike is about $50^{\circ}$. In Wādī Gharīsh, E.A.P., clearly visible relic bedding in garnet-staurolite-mica schist strikes at about $330^{\circ}$, whereas foliation strike is about $10^{\circ}$. In these areas the discrepancy does not appear to result from divergence of axial-plane foliation from bedding in the nose of a fold.

Further evidence for refolding occurs in the Sa'id area where fine-grained quartz-biotite gneiss shows postcrystalline deformation. The fold core shows quartz, and biotite-rich layers, and in the latter biotite flakes follow the folding, showing some minor distortion in the crestal part. This distortion is considered to be due to refolding of a foliated rock rather than to mimetic crystallization.

Petrographic evidence for renewed stress following initial development of foliation is shown in a number of specimens by such effects as crumpling of an earlier schistosity and two generations of quartz and mica. (See also "Metamorphism.")

The earlier stress period recognized seems to have affected basement rocks at considerable depth where temperature elevation enhanced by granitic invasion reduced the rocks to a partly plastic condition. Ptygmatically folded veins of granitic material, which occur in zones peripheral to syntectonic granite, are probably associated with plastic deformation of the host rock, which is also indicated by similar folding. Many feldspathic bands and some pegmatites, folded con- 
cordantly with intricately folded country rooks, provide structural evidence for syntectonic granite invasion, because the bands are associated with these granites.

Rocks showing evidence of polymetamorphism, which have undergone at least two periods of stress, are those classed as the Aden Metamorphic Group and the associated syntectonic granites. A second class of rocks shows mainly the effect of dislocation metamorphism, such as deformation of mineral components, cataclasis, and shearing. This class comprises the intertectonic igneous rocks of W.A.P. and the older volcanic and Wādi al Ghabar metasedimentary rocks of E.A.P. The later metamorphism which affected these rocks operated at effectively higher levels, owing probably to some denudation of cover rocks between the time of the earlier mesozonal metamorphism and the later epizonal effects. The latter resulted in the imposition of strainslip cleavage upon basement rocks over a wide region, extending from southwestern Hadhramut to the western part of the Protectorate. An example of this is seen in an eastern tributary to Wādi Gharissh, where platy quartzitic rock is interbedded with more argillaceous sandstone. Fracture cleavage making a high angle with bedding planes is strong in the less competent member. Shear zones present in a number of areas are exemplified by that seen in the Mukayrās pass where dioritic rock of the intertectonic igneous phase is cut by shear planes at steep angles, along which is phyllonitic rock.

To summarize, the available evidence indicates at least two important stress periods. The earlier period affected basement rocks in a partly plastic state and resulted mainly in close isoclinal folding of similar type. Axial planar foliation was developed due to metamorphic recrystallization. A later period of stress appears to have caused some refolding of foliated basement rocks and folding of the later Wādi al Ghabar metasedimentary rocks. At this stage fracture cleavage was developed and is shown in the multidirectional cleavage planes of the older volcanic rocks of E.A.P. and in many of the W.A.P. basement rocks. This strainslip cleavage does not appear to have progressed through recrystallization to the production of schistosity or gneissic banding, and it does not obliterate older structures, some of which are expressed as contortions of earlier schistosity. Shearing and cataclastic deformation also resulted from the later stress phase. Granitic intrusions of presumed early Paleozoic age have not been similarly affected.

\section{POSTBASEMENT STRUCTURE}

The structural features associated with postbasement rocks of the western part of the Protectorate must be considered in relation to the Eastern Protectorate where by far the greater proportion of Jurassic and later rocks are exposed. Beydoun (1961) gave a full account of these rocks in E.A.P., from which data have been extracted and are included in the following discussions. Reports of restricted occurrences of Paleozoic rocks in W.A.P. (Jaques, unpublished data, 1952) have not been confirmed in the recent survey.

Late Jurassic-Early Cretaceous structure.-Beydoun reported faulting and local folding associated with faulting in E.A.P. in late Jurassic or Early Cretaceous times. He adduced evidence for movements at the end of deposition of the Shuqra Formation (Lower Oxfordian), suggesting emergence and the rise of a barrier. At the end of Shuqrah times this barrier was assumed to have isolated an evaporitic inland basin in which the Sabatayn Formation (correlated with the Medbi, overlying the Shuqra Formation) was deposited. Intraformational conglomerates in the Naifa Formation [Upper Kimeridgian-Tithonian] indicate erosion of an emergent barrier which was overcome to allow the Naifa Formation to spread inland over the evaporitic basin, and to overlie the Sabatayn Formation as it overlies the Madbi Formation. The exact position of the postulated Jurassic barrier is not known, but it may have been alined westward to the south of the axial region of the present south Hadramawt arch.

At the end of the Upper Jurassic, faulting took place. According to Beydoun, this appears to have been mainly block faulting, perhaps due to relaxation from uplift. The fault direction is dominantly north, but some east-trending fractures are also present.

Beydoun noted that the terminal Jurassic movements divided the territory into major north-south highs and lows, which were differentially eroded before the Cretaceous cover was laid down. The north-south features extend across the whole territory and were thought to be due to faulting along old trends in the basement rocks. The most important uplift is the Mukalla high. A subsidiary high was noted in the eastern part of W.A.P.

Over the western part of the Protectorate little information concerning Jurassic structural conditions can be obtained, as Jurassic rocks in this region are preserved as faulted blocks and strips of fairly restricted extent. Jurassic strata are preserved along the faulted escarpment extending southwestward from near 'Ataq toward the coast and also in an area of complex faulting to the south of Mayfa'ah, Al Wāhidì. From the neighborhood of Al Mahfid west-southwestward to the longitude of Aden, Jurassic together with Cretaceous rocks on the basement rocks are preserved in places by faulting in mainly east-northeast to east directions. 
Jurassic rocks also occur in an area of mainly northwest faulting at and to the east of $\mathrm{Al}$ 'Anad.

The salt domes of 'Iyādh, Lai'adin (Ayadim) (about 38 miles N. $64^{\circ}$ E. from An Nuqūb, Baybuann) and of the Shabwah area are present in rocks of the Sabatayn Formation. The Naifa Formation is represented in the 'Iyādh dome.

Cretaceous structure. - Beydoun recorded no important faulting or folding in the Eastern Protectorate during the Cretaceous, but epeirogenic subsidence and local uplift was thought to have occurred. He noted that in Aden Protectorate and in the former Somaliland Protectorate the overall trend of facies lines is north, indicating new easterly tilt of the land surface and transgressions from the east.

In the west-central subcoastal areas of the Aden Protectorate, Cretaceous beds resting upon Jurassic strata are preserved in faulted strips. To the east of a line between Aḍ Dāli' and Al 'Anad, Cretaceous rocks crop out at the margin of volcanic rocks of the Aden Trap Series, which they appear to underlie in the southwestern areas of the Protectorate. Their relation to the trap series is difficult to discern because in most places the contact is one of faulting. The balance of evidence suggests that volcanic rocks are later than exposed Cretaceous strata. At 'Awābil and Al 'Anad, Cretaceous sandstone rests directly upon basement rocks. The evidence indicates marine transgressions from a easterly direction, advancing up the slope of the tilted Arabian shield and resulting in a diminishing thickness of deposits from east to west. In the westernmost parts of the Protectorate, continental (and possibly lagoonal) deposits replace the marine deposits of the east.

Paleocene and Eocene structure.-No faulting or folding was recorded by Beydoun in the early (Paleocene) stage of the Tertiary subsidence in E.A.P., but in Paleocene and middle Eocene times the progressive development of the biaxial Hadramawt arch began. This feature attained its present form about the end of the Eocene, but the collapsed south flank resulted from faulting in the later Tertiary.

Beydoun noted that the structure is divided into north and south arches by an intervening gentle syncline, all the folds trending west-southwest in Hadramawt, but swinging to the east in Al Mahrah.

The south Hadramawt arch is intersected in the west by a zone of west-northwest faulting across its axial line, and the arch loses its identity toward the Western Protectorate border. The flanks of the folds show very gentle dips amounting to about $1^{\circ}$ overall, but the southern flank of the south arch is in the form of a broken scarp owing to extensive faulting associ- ated with the Gulf of Aden rifting. Beydoun regarded the arching as due to warping rather than faulting.

Eocene sedimentary deposits are barely represented in W.A.P., but the Eocene structural history of E.A.P. is relevant to the study of the W.A.P. structure. The Hadramawt folds discussed by Beydoun (1961) are shown on plate 2 . The fact that these die out in the region of a major fault zone of northwest trend, which throws strata to the east against western basement rocks, reinforces stratigraphic evidence for thinning of Eocene deposits to the west and suggests that the fault zone referred to was active in Eocene times, being associated with basement uplift and reduced sedimentation. In view of the occurrence of Eocene sedimentary rocks at $\mathrm{Al}$ Mahfid, west of the presentday faulted escarpment, it cannot be postulated that the fault zone referred to limited the westward extension of Eocene deposition. Nevertheless, it would seem that this zone of faulting lies on or near the eastern border of a regional uplift that resulted in the present exposure of the main mass of basement rocks in W.A.P. To the west of this fault zone all strata of Jurassic and later age are in faulted relationship to basement rocks, as opposed to forming an extensive cover, as is true to the east. The near-complete absence of down-faulted remnants of Eocene rocks over the western area strongly suggests that these were not deposited over most of the region.

It may be inferred that the elevation of the basement rocks in the western part of the Protectorate formed a barrier to the westward advance of Eocene transgressions. This elevation was of epeirogenic type. It is reasonable to correlate this uplift with the incidence of volcanic activity of Late Cretaceous or early Tertiary age that occurred in the southwest. The original eastward limit to the spread of these volcanic rocks of the Aden Trap Series is not known but they are separated from uplifted basement rocks by faulting, a major zone of which trends north-northwest to the east of a line between Ad Dāli' and Al 'Anad. The extension of the eastern boundary of the volcanic rocks into Yemen, as mapped by Geukens (1960), suggests that the volcanic rocks are preserved in a depressed zone flanked to the east by a tectonic ridge trending generally north-northwest.

Oligocene and Miocene structure.-Beydoun stated that subsidence and progressive marine ingression from east to west occurred in the Gulf of Aden during the Oligocene and Miocene times, and he considered that during this phase of relaxation from compressional uplift, associated with the development of the Hadramawt arch, normal faulting parallel to the axis of folding broke up the south flank of the (south) arch. Coastal Oligocene and Miocene deposits (Shihr Group) 
have been tilted by fault movements, which Beydoun considered to predate Gulf of Aden faulting.

Neogene and Recent structure.-Beydoun considered Gulf of Aden faulting of east-northeast trend to be fairly common; he noted long straight stretches of coastline which follow this direction and which have undergone relative elevation in Neogene to Recent times, as shown by the fact that Oligocene and Miocene deposits are involved in the uplift. Evidence for faulting of Oligocene and Miocene deposits is lacking in W.A.P. where such deposits are not recorded. Relative uplift of the land is shown by terraces of alluvial material standing at heights of 35-75 feet above incised wadi course. In Wādi Abwar a welldeveloped oxbow isolated some 35 feet above the present wadi bed indicates a period of stability followed by a very recent change of base level. Faulting in basalt flows of the Aden Volcanic Series between Shuqrah and Abwar, alined in the Gulf of Aden trend, indicates late epeirogenic movement, probably in Recent times.

Summary.-The very extensive folded sedimentary cover of Jurassic to middle Eocene rocks of E.A.P. does not occur west of a northwest-trending fault zone which extends from near 'Ataq to the coast a little east of 'Irqah. This fault zone may continue to the northwest, under the sands of the Ramlat as Sab'atayn, to link with major faults of the same trend that are mapped in Yemen.

To the west of this fault zone, in the subcoastal region of west-central Aden Protectorate, Jurassic and Cretaceous strata are preserved in restricted elongate outcrops faulted against the basement rocks by faults of east-northeast to east trend. The Cretaceous rests upon Jurassic and the latter upon peneplaned and weathered basement rocks. Recorded Eocene in W.A.P. is limited to an exposure in a small downfaulted syncline at Al Mahfid.

In the southwest of the Protectorate, east of a line between Aḍ Dāli' and Al 'Anad, a second major fault zone trending generally north-northwest, with northwest components, marks the western edge of the main basement block of the Protectorate. Jurassic and Cretaceous beds are exposed in faulted strips along this zone. At 'Awābil, Al 'Anad, and elsewhere in this western region, Cretaceous sandstone rests directly upon basement rocks. West of the fault zone an extensive area of volcanic rocks of the Aden Trap Series occurs. As suggested by Geukens in the case of Yemen $(1960$, p. 178), it is considered that these volcanic rocks are underlain by Cretaceous sandstone of Nubian type. The volcanic rocks are of Late Cretaceous or more probably Tertiary age. They are cut by faults which very generally trend northwest, and this trend is also followed by many dikes of the area.

It is considered that the Aden Trap Series and the underlying Cretaceous sandstone, which is preserved from denudation by the volcanic cover, occupy a structurally depressed region flanking a tectonic high to the east. The high was caused by epeirogenic uplift associated with faulting. A causal relation between uplift and volcanic activity is recognized and it is likely that uplift occurred in latest Cretaceous or early Tertiary times and formed a barrier to the westward extension of the Eocene transgression of E.A.P. The Aden Trap Series is regarded as roughly coeval with Paleocene of E.A.P. The fault zone east of the Ad Doali'-Al 'Anad line lies along the western flank of the uplift, and along an extension of this northnorthwest-south-southeast line into Yemen there is evidence of erosion of Jurassic and Cretaceous deposits and diminution of thickness of volcanic rocks (Geukens, 1960 , p. 139, 153-154). Geuken's map of Yemen completed the picture in Aden Protectorate of volcanic and sediments thinning out against uplifted basement rocks, although the fault zone which marks this uplift in the Protectorate is not (yet) mapped in Yemen.

The eastward extension of the uplift barrier cannot be exactly defined, but it is noted that the northwesttrending fault zone passing near 'Ataq, and probably linking with similar faults in Yemen, demarcates the eastern extent of the main basement block in both Aden Protectorate and Yemen, and may lie along the eastern flank of this basement uplift.

The assumption of an uplift in Late Cretaceous to early Tertiary times, associated with faulting along trends roughly parallel to that of the Red Sea axis (with which direction many eruption fissures of the trap series in Yemen are coincident (Wissmann and others, 1942, p. 290), suggests recognizable manifestations of development of the Red Sea rift dating from this time.

\section{FAULTING}

Main fault directions in the Gulf of Aden region are classified as follows. The east African trend ranges from north to north-northeast; the true Erythrean or Red Sea trend is northwest, but faults following a west-northwest direction may be included in this class; the Gulf of Aden trend is east-northeast and in strict usage should be differentiated from the east Somali trend; however, this distinction is not everywhere adhered to; the Aualitic trend is northeast.

The major faults of W.A.P. and southwestern Hadramawt are shown on plate 1. The fault pattern 
over a wider region of southern Arabia and the former Somaliland Protectorate is shown on plate 2 .

\section{FAULTING OF EAST AFRICAN TREND}

Faults of east African trend are of somewhat restricted and generally local occurrence. They are mapped in the basement rocks of the Baybsann area, in the Jibāl an Nisiyin block, and to the northeast of Abwar; also in other basement-rock areas. An extensive fault following the line of Wādī Raybān, to the southwest of Lawdar, maintains a north-northeast trend along much of its length before swinging to a northeast direction in the north. Although faults of this class may follow basement strike direction, this is not always true; southwest of Lawdar and southeast of Khawrah, faults cut across foliation strike at high angles.

In many places faults of east African trend are displaced by those of Gulf of Aden trend (s.l.). Thus in E.A.P., faults bounding the Wādì al Ghabar metasedimentary rocks are alined approximately along the east African trend and terminate against and are offset by east-trending faults. Faults of west-northwest trend also appear to be of later date in this locality.

\section{FAULTING OF RED SEA TREND}

Faults following the Red Sea trend, as loosely defined, form an important feature of the Protectorate fault pattern.

The 'Ataq fault zone.-A major zone of faulting of Red Sea trend extends for over 60 miles from near 'Ataq to the locality of 'Irqah in the coastal plain. The northwest-trending faults, dominant in this zone, both offset and are offset by east-trending and west-northwest-trending faults, and may swing to the west-northwest direction. It is probable that this zone of Red Sea faulting extends into Yemen through the Ramlat as Sab'atayn.

The 'Ataq fault zone marks the eastern border of the main block of basement rocks of the Protectorate and over much of its length is parallel with the strike of basement rocks immediately to the west. Farther to the west the basement strike trends roughly east but swings into parallelism with the fault zone. A prominent faultline scarp is formed by sedimentary rocks to the east, which dip away from the basement junction in a general northeasterly direction. The present surface expression is of normal faulting, which has thrown down Jurassic and later sedimentary rocks against basement rocks (fig. 23). Where observed near As Sufāl, the dip of the fault plane is steep and there is evidence of variation of apparent vertical displacement along the

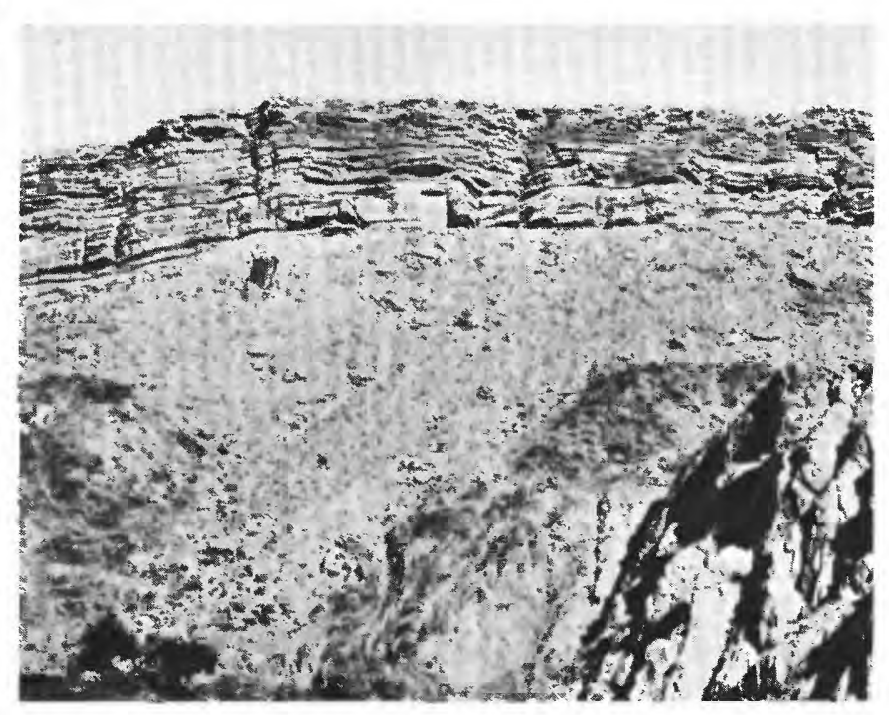

FIgURE 23.-Jurassic limestone faulted against schist along part of the 'Ataq fault zone, Ass Sufãl.

fault strike. It is possible that transcurrent faulting at depth, of ancient inception, is expressed by later vertical movement at the surface, and this theory may also be supported by the rectilinear trace of the main faults.

The Dhala fault zone--Bounding the main basement block to the west is a second major zone of faults of Red Sea trend (s.l.) in which the characteristics of a fault zone are more clearly expressed by numerous faults trending north-northwest and northwest. Faults of the general Gulf of Aden trend that occur here appear to be mainly of later date.

The Dhala fault zone, some 6-7 miles east of a line between Aḍ Dāli' and Al 'Anad, separates basement from volcanic rocks of the Aden Trap Series and along the margin of the basement rocks, faulted blocks of Jurassic and Cretaceous sedimentary rocks are preserved; these dip away from the basement rocks in a general southwesterly direction. The faulting also preserved the volcanic rocks - of Late Cretaceous or Paleocene age - in the downthrown basinal region to the west; the inception of the faulting in Late Cretaceous or Paleocene times is indicated by the absence of volcanic rocks to the east of the fault zone. If the fault zone postdated volcanic activity, preserved volcanic remnants might be expected to occur over the basement rocks to the east, as is true of Jurassic and Cretaceous rocks. Alternative explanations for the absence of volcanic rocks east of the fault zone involve nondeposition of these east of a fairly sharp line of demarcation, or cessation of down faulting over the basement-rock area subsequent to the Cretaceous Period. Both these postulates are highly improbable. 
Faulting in the Aden Trap Series.-The Red Sea trend (s.l.) is dominant in faults cutting the Aden Trap Series in the southwest of the Protectorate and many of these faults follow the true northwest-southeast Red Sea direction. The volcanic rocks were originally disposed in subhorizontal sheets, but over much of the area they are tilted by strike faults and dip generally to either the northeast or southwest. In several areas, for example, southwest of Al Musaymir and northwest of Ghayl Barbar, Cretaceous sandstone is exposed in the volcanic area by faults of Red Sea trend.

The 'Iyâdh fault zone.-In southwestern Haradmawt a zone of faults trending west-northwest to northwest, expressed largely in Eocene sedimentary rocks, can be followed from 'Tyādh to the locality of Neifa on Wādi Hajr. Here the clear expression of this trend is lost in complex faults that follow several directions. Against this zone of faults of Red Sea trend (s.l.), the southern anticlinal fold of the Hadramawt arch fades out. To the east, faulting in the sedimentary cover trends dominantly east or east-northeast. Although faulting on west-northwest lines occurs in the Ra's Sharwayn-Ra's Fartak area, it is likely that this differs from the 'Tyādl zone of faulting in origin and time of initiation. Beydoun (1961) suggested that some of the faulting on west-northwest lines may have developed during the culmination of geanticlinal warping as a form of adjustment to differential crustal shortening, and he suspected that some transcurrent movements involving the Gulf of Aden trend may be associated.

The zone of faults extending southeast from 'Tyädh is flanked at its southeastern end by an area of exposed basement rock that extends eastward to Al Mukallā. Beydoun (1961) recorded an old high of igneous basement rocks in the Al Mukallā area. He suggested that this feature was formed by uplift during post-Jurassic faulting but that this movement could have been one of rejuvenation. These observations support the suggestion that the 'Iyādh fault zone is the expression of a reactivated ancient fault trend connected with the uplift of the $\mathrm{Al} \mathrm{Mukallā} \mathrm{high} \mathrm{and} \mathrm{resulting} \mathrm{in} \mathrm{a} \mathrm{comple-}$ mentary depressed area between this and the main block of presently exposed W.A.P. basement rocks to the west, the latter being also margined by the 'Ataq zone faults of Red Sea trend. In this depressed zone, basement exposures are limited, although the elongate basement range of Jibāl al Aswad forms a prominent feature flanked by west-northwest-trending faults parallel with the foliation strike. The expression of rejuvenated(?) Red Sea trend faulting (s.l.) in the sedimentary cover of the depressed zone, as contrasted with the greatly reduced expression to the east, may be related to the reduced thickness of Tertiary cover, which is also reflected in the fading of the Hadramawt arch to the west. It is noted that in former Somaliland Protectorate, faults of Red Sea trend (as other faults), that extend inland from the sunken coastland (basement) region die out as they penetrate the sedimentary plateau (Somaliland Oil Exploration Company, Ltd., 1954, p. 33-34).

Apart from the zones mentioned above, faults of Red Sea trend (s.l.) occur over much of the basementrock region; they may cut across foliation strike directions as in the Wādì Banā area southwest of Mukayrās, and in the Bayhān area. These faults may throw to northeast or southwest. In Wādì Abwar a small reverse fault, striking northwest, dips steeply to the northeast and throws down to the southwest.

\section{FAULTING OF AUALITIC TREND}

Faults following the northeast Aualitic trend, parallel with the main Ethiopian rift direction, occur in the western part of the Protectorate, as in Yemen, but they are comparatively few. In the E.A.P. significant faulting on this trend is apparently not recorded. In common with faults of other classes, faults of Aualitic trend may swing to follow other trends.

A major fault of this trend runs for some 25 miles parallel with the fault scarp of the Kawr al 'Awādhil passing to the north of Lawdar. It is probable that this fault, or a parallel fault, extends farther to the northeast along the Wādi Durā. The fault follows basement strike.

In the region to the east of the upper Wādi Banā, faults of Aualitic trend are somewhat transverse to basement-rock strike. The longest of these can be traced for 25 miles before it swings to an east-northeast direction in the southwest. Other faults of the same trend cut basement rocks and Jurassic and Cretaceous rocks northwest of Ar Rawdiah, to the north of Aden, and in the area south and southeast of Baybann.

\section{FAULTING OF GULF OF ADEN TREND}

As noted, the Gulf of Aden trend strictly refers to faults trending east-northeast. Many faults that follow this direction over part of their course swing to east or even west-northwest trends. These are all included under Gulf of Aden trend (s.l.).

The distribution of Gulf of Aden faults in W.A.P. is fairly uniform except that their expression is much restricted in the Aden Trap Series in the southwest. Few of the individual faults of this class are of great length, but a nearly continuous line of faults some 28 miles long through Wādī Habbān and Yashbum is noted. Further extensive faults on the same trend occur south and southwest of Al Mahfid. 
Faulting of the Gulf of Aden trend is mainly responsible for the preservation of elongate strips of Jurassic and Cretaceous sedimentary rocks in the basement-rock area in the coastal zone between the longitudes of Aden and 'Irqah. The width of these faulted blocks generally does not exceed 4 miles and in many places is less than 1 mile; in length a practically continuous strip extends for some 80 miles. Traverses inland in a north-south direction may cross four or more of these faulted blocks with intervening basement rock or basalts of the Aden Volcanic Series, as between Shuqrah and Lawdar. The characteristics of many of these faulted blocks is exemplified by that occurring some 30 miles northwest of Ahwar. Here Jurassic limestone is preserved by normal faults striking parallel with, and dipping northward in the same direction as, basement strata - that is, parallel with basement bedding planes. The Jurassic beds of the tilted block dip southward in the opposite sense to basement foliation (and relic bedding) and rest upon basement rocks to the north. Similar fault blocks occur to the northwest of Shuqrah and at the northern edge of the coastal plain north of Aden; in these blocks tilted sedimentary beds dip at about $25^{\circ}-30^{\circ} \mathrm{S}$. against strike faults downthrown to the north. The dip of the fault planes is about $50^{\circ}$. In some places the faults throw sediments down against basement dip in the opposite sense to basement foliation, as in the area 8 miles west of Nūsah, where faults are downthrown to the south.

Wissmann, Rathjens, and Kossmat (1942, p. 293) recorded, near the foot of the Kawr al 'Awādhil, narrow ridges of basement rocks bearing nappes of Jurassic limestone dipping south-southeast. These form narrow fault blocks bounded by faults that strike east-northeast and dip north-northwest. The distance from fault to fault is estimated at $2-3 \mathrm{~km}$ on the horizontal, so that a "staircase" of narrow fault blocks is formed. The fault planes dip in the opposite direction to the faulting responsible for the main scarp. With respect to this main fault, the faulting of the stepped blocks may be described as antithetic. The fault planes of these blocks run parallel with the (relic) bedding planes of the basement rocks which form preferred directions for the downthrow faults. Wissmann suggested that the tilt direction of the faulted sedimentary blocks is inversely related to the dip of the basement strata.

These observations accord with the relations seen in many of the faulted sedimentary blocks in basementrock areas, but as noted above there appears to be no constant relation between the direction of throw of the faults, and hence tilt of the blocks, and dip direction of the basement rocks.
Although faults of Gulf of Aden trend in several areas, and particularly in the west-central part of the Protectorate, run parallel with basement strike, this coincidence is not universal.

A few faults of Gulf of Aden trend occur in basalts of the Aden Volcanic Series, between Shuqrah and Abwar.

In E.A.P., faults trending east and east-northeast are numerous, particularly on the south flank of the Hadhramut arch, as noted by Beydoun (1961).

\section{GENERAL}

Faults in the Aden Protectorate are generally of normal type, as expressed at the surface. Minor reverse faults occur in basement rocks, as in the Abwar district, and a small thrust fault involving Cretaceous and Jurassic beds is recorded in the lower Wādi Hajr of E.A.P.

In some places the normal fault probably represents the latest increment of movement along ancient shear directions in which earlier deeper movements were of transcurrent or wrench faulting. This seems particularly likely for northwest- and northeast-trending faults, which show long and straight traces and in which the dip of the fault plane is high. Faulting on these trends may occur as a complex zone, which is again a common expression of deep wrench faulting. Considerable variation in throw along the strike of these faults is seen.

Although shear planes in basement rocks are widely seen, no conclusive evidence for transcurrent faulting can be presented. However, aerial photoraphs of folded basement rocks in an area south of Al Mahfid show long and straight faults on Gulf of Aden trends, in which displacement of steeply dipping beds may be as much as 800 yards (fig. 24). In E.A.P., faulting in a west-northwest direction was suspected by Beydoun (1961) of being related to transcurrent movement, and he suggested tangential stress, due to horizontal components of fault movement, as a factor in the development of salt diapirism.

In former Somaliland Protectorate, in a similar tectonic setting, faults of Red Sea trend (a) show highangle to vertical dip of fault planes; (b) frequently attain a large throw and then die out abruptly; (c) may occur as scissor faults; (d) are frequently arranged en echelon; and (e) have generally straight courses. These characteristics may be the surface expression of buried wrench faults. It must be added, however, that mylonitized zones were not recorded by Somaliland Oil Exploration Company, Ltd. (1954).

For the present it must be enough to recognize that a number of the major faults of Aden Protectorate may 


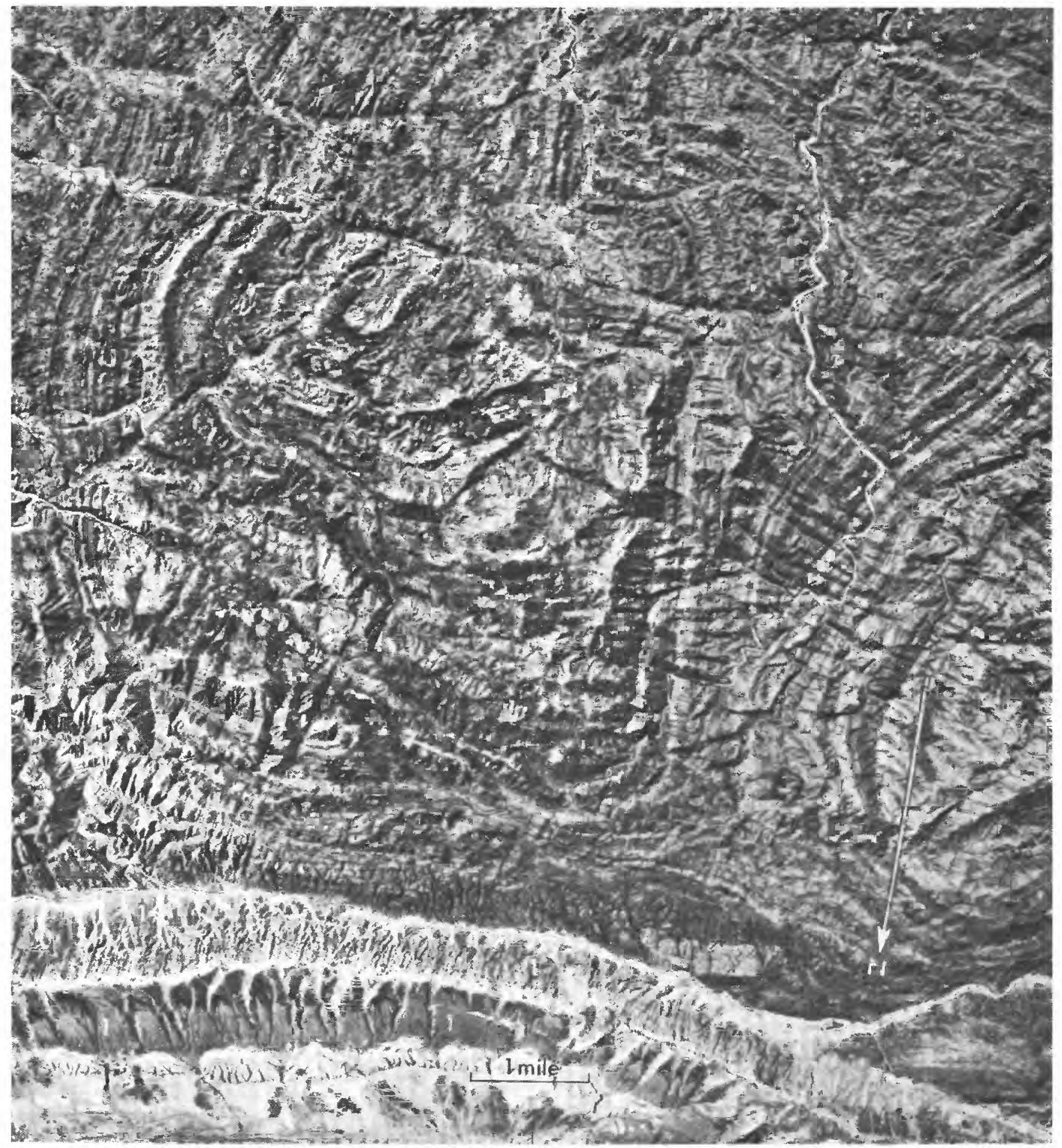

FIgURE 24.-Faults and folds in basement rocks, about 8 miles so outh-southeast of Al Mahfid. The trace of a major fault extends across the sonthern part of the area in a direction nearly east-west. To the north, Jurassic beds (1) are faulted against the basement. Royal Air Foree photograph. Crown copyright reserved. 
be of ancient origin and originally of transcurrent type. Rejuvenation of ancient trends is suggested and although periods of marked vigor are recognized from Late Jurassic onward, these probably represent phases in a much longer succession of movements.

\section{AGE OF THE FAULTING}

Observations on faulting over a wide region show that the faulting of any one trend was not confined to a single period. It is, however, possible to be more specific with regard to the dating of certain main periods of faulting.

Evidence has been given to suggest that important phases of faulting on Red Sea trends date from Late Cretaceous or Paleocene times. Along Aḍ Dāli'-Al 'Anad fault zone Cretaceous beds rest directly upon basement rocks in some localities. This may indicate faulting and erosion prior to Cretaceous deposition, because Jurassic strata are preserved upon basement rocks elsewhere in the same general area. Northwesttrending faults affect middle Eocene strata in the Mayfa'ah district and elsewhere in E.A.P., but faulting on this trend does not appear to cut Oligocene and Miocene coastal deposits, at least to as far east as long $50^{\circ} \mathrm{E}$., which marks the limit of photogeological mapping. Much faulting on west-northwest lines is present in the Eocene of .E.A.P., and Beydoun (1961) suggested that this may have occurred at the culmination of geanticlinal warping, presumably in Late Eocene times.

On the evidence available, it is suggested that faults of Red Sea trend (s.1.) date from at least Late Cretaceous times, with a possible earlier inception in the Late Jurassic. There are no data proving faulting in this trend later than late Eocene.

In W.A.P., Gulf of Aden faulting in at least two periods is shown by the fact that Red Sea faults both offset and are offset by faults of Gulf of Aden trend. A number of the latter faults, expressed in basement rocks, terminate against northwest-trending faults of the 'Ataq fault zone, and do not appear in Jurassic and later sedimentary rocks to the east. In former Somaliland Protectorate, erosion and removal of Jurassic strata over large areas may indicate extensive Jurassic, or Early Cretaceous, faulting, and Somaliland Oil Exploration Company, Ltd. (1954, p. 37) suggested the possible existence of an early Somaliland plateau, trending roughly east-northeast, in Early Cretaeous times. This may result from Gulf of Aden faulting dating from this period.

No direct evidence as to the date of initiation of a more recent period of Gulf of Aden faulting is obtainable from W.A.P., but in E.A.P. Oligocene and Miocene deposits are banked against older strata in the coastal areas east of Al Mukallā; these deposits resulted from subsidence and marine transgression over a coastline parallel with the Gulf of Aden axis. As in Somaliland, their distribution indicates the existence of a Gulf of Aden at this time. The deposits are tilted by faults of Gulf of Aden trend.

It seems clear that a main phase of Gulf of Aden faulting dates from Oligocene or early Miocene times. Continuation of this faulting into Pliocene, or probably Recent, times is shown by the following observations: 1. Long sections of coastline following the Gulf of Aden direction were elevated in Neogene to Recent times, as indicated by reef deposits of Miocene age involved in the uplift.

2. The final breakdown of the Red Sea-Indian Ocean barrier has been referred, on fossil evidence, to middle Pliocene times (Cox, 1931). This indicates Gulf of Aden movements at this date.

3. East-trending faults have been mapped in basalts of the Aden Volcanic Series between Shuqrah and Ahwar. The basalts are considered to date from late Miocene or Pliocene to Recent times. Many of the flows in the Shuqrah area are of very recent origin.

With regard to faults of east African trend, in the basement rocks of W.A.P. these both offset and are offset by faults of Gulf of Aden trend. That a number of east African faults terminate against faults of Gulf of Aden trend suggests that some faults of east African trend are either contemporaneous or of later date. As similar relations exist vis-a-vis faults of Red Sea trend, east African faulting may be both older and younger than faulting of other trends. It is, however, noticeable that no major faults of east African trend are expressed in the sedimentary cover of E.A.P. Movements at the end of the Jurassic in E.A.P. resulting in major highs and lows, may have been due to faulting on north-south lines, possibly along basement strike directions. Rejuvenation of ancient faults may be suspected.

Faulting of the northeast-southwest Aualitic trend is seen in the W.A.P. basement rocks and to a lesser extent in Upper Cretaceous and Paleocene volcanic rocks in the southwest of the Protectorate, but it is not recorded in the sedimentary cover of E.A.P. In the region of the upper Wādi Banā numerous faults of Red Sea trend terminate against a major northeasttrending fault, which may suggest the prior origin of the northeast-trending fault. To the southeast of Nişāb, faulting of Aualitic trend is offset by Gulf of Aden faulting. Thus faulting of northeast trend is earlier than at least some of the faulting of other trends, but definite evidence as to the age of this faulting is lacking. 


\section{GENERAL COMMENTARY ON STRUCTURE}

Many workers have made reference to the structural history of the Gulf of Aden and surrounding region, which is of particular interest insofar as it includes the confluence of the tectonic features of the Red Sea, Gulf of Aden, and Ethiopian rifts. Mention may be made of the work of Gregory (1921), Krenkel (1925), Lamare (1936), Picard (1937), Cloos (1939), Wissmann, Rathjens, and Kossmat (1942), and Carey (1958), although this by no means exhausts the list. There is considerable divergence in the views expressed, centering mainly on the relative importance of tensional, compressional, and drifting mechanisms.

Hitherto few data have been available regarding basement strike and faulting pattern in W.A.P. Of the several main hypotheses that might be advanced to explain the broad structural features of the region, that based on the concept of the regmatic shear pattern shows most promise of eventual reconciliation with the facts. This concept has developed through the work of Hobbs (1911), Vening Meinesz (1947), Moody and Hill (1956), and others. The term "regmatic shear pattern" was introduced by Sonder (1947).

According to this concept the earth's crust is intersected by major shear lines of worldwide distribution, those directed northwest and northeast being primary shear directions. The primary shear directions may be associated with subsidiary directions trending north and east, and in other directions orientated symmetrically with regard to the major primary stress. The actual expression of shearing may depart from the directions derived from purely theoretical considerations. These shear lines are considered to be of ancient-primordial-origin but are subject to reactivation at various periods following renewal of stress, which may result in further transcurrent shearing, or in tension or compression. Stress acting upon a segmented crust may result in differential movement along margins of basement blocks, in block jostling, and in complex movement of basement blocks beneath a sedimentary cover. As noted before, transcurrent or wrench faulting at depth may be translated into essentially vertical movement at the surface.

It is beyond the scope of this paper to consider in detail the evidence for the existence of these ancient shear zones, but it is noted that Precambrian effects associated with, and alined along, Jurassic and Tertiary east African rifts include thrusting, shear zones, mylonitization, igneous intrusion, and migmatization. Stocks' (1941) chart of the Gulf of Aden shows a series of submarine ridges and channels in the eastern part of the Gulf which trend northeast along a primary shear direction.
Considered in terms of the regmatic shear pattern, the fault pattern of the Protectorate may be resolved into primary northwest and northeast shear directions and subsidiary shear directions, among which the Gulf of Aden east-northeast trend would be classed as a second-order shear direction.

The major fold axes of the Protectorate basement rocks trend in various directions, but this of itself does not necessarily imply differing directions of primary stress. Evidence on the earlier structural history of the Protectorate clearly suggests a number of major features trending generally north. In the E.A.P. occurs the basement-rock high of Al Mukallā; the main basement block of W.A.P. may represent a swell trending generally north; terminal Jurassic movements in E.A.P. are thought to have divided the territory into major north-trending highs and lows. Old north structural trends are known in several areas in south Arabia and a system of meridional troughs and swells may be suspected in this region. These observations might suggest that stress affecting the older rocks of the Protectorate involved a dominantly east, rather than north, component, and this is supported by the fact that in the north part of the Protectorate, away from the influence of the Gulf of Aden shear zone, the basement strike shows a strong north component which is continued over much of western Saudi Arabia and Yemen. (In Saudi Arabia folds trend mainly north, northeast, and northwest. In Yemen the older Wadi Medina Series strikes generally north.)

It is probable, however, that most, if not all, of the highs referred to were due to, or accentuated by, faulting following regmatic shear directions. The question arises as to the nature and orientation of the stress causing these faults. There is no direct answer to this, but the mechanism of uplift may have been controlled by faulting along northwest-southeast lines resulting from primary compressional stress in an east-west sense. The main basement block is bounded to the east and west by faulting on these lines; that the elevation of Al Mukalla high is also due to such faulting is to some extent supported by the fact that the complementary depressed area to the west of $\mathrm{Al}$ Mukalla is also bounded to the east by a fault zone of Red Sea trend. That faulting of this trend was originally of transcurrent type and was caused by dominantly east-west stress is supported by evidence from western Saudi Arabia. Here, Brown and Jackson (1960) recorded a number of major northwest-trending faults, of which the most prominent, the Nejd wrench fault, apparently shows sinistral movement, as the northern block, has moved westward with respect to the southern block. The entire pattern was said to be 
that of a regional force couple. It was also noted that slight movement is seen in the Cambrian and Ordovician sandstone where the Nejd fault disappears beneath the Paleozoic basin to the north but no evidence of movement was seen beneath Permian limestone at the southeastern extension. Indications that major northwest-trending faults in the Protectorate may have originated as transcurrent movements have been noted elsewhere. In summary, it seems likely that the general directon of stress causing these faults was east-west.

It has been stated that the basement strike direction swings from being alined roughly parallel with the Gulf of Aden to becoming parallel with the northwesttrending 'Ataq-'Irqah fault zone. This could result from transcurrent movement along this zone and the consequent drag effect on deeply buried basement rocks, but the observed structure of the wider basement-rock region could not result from movement along faults of Red Sea trend only. The structure observed is, however, commensurate with movements reflected from major northwest-trending fault zones (possibly represented by the 'Ataq zone and its extension into Yemen, and a zone alined along the Red Sea axis) in combination with similar movements along a zone parallel with the Gulf of Aden. The overall trend of basement strike in the southern more coastal region of W.A.P. is approximately parallel with the geosuture now marked by the Gulf of Aden and provides an example of folding and foliation parallel with the controlling fracture belt. In the northern part of W.A.P., the influence of the Gulf of Aden geosuture wanes as a controlling factor in basement structure, and a more complicated pattern results from the increased influence of shear zones of other trends.

The preceding suggestions are necessarily speculative, but it is considered that some such translation of an east-west primary stress, transmitted through transcurrent movement along ancient shear zones, best fits the observed structure. Relatively minor and local variations in stress distribution is attributed to basement block jostling.

The structure of the older basement rocks may, with some confidence, be attributed to the interplay of shearing movements along different trends and may be ultimately related to a primary east-west stress. It is somewhat difficult to explain in the same context the more uniform approximately north strike of the Wādi Ghabar metasedimentary rocks and their suggested equivalents in former Somaliland Protectorate, the Inda Ad Series. There is evidence from the Arabian shield region, as elsewhere, that shearing and transcurrent movements at depth are commonly not reflected along the same fault zones at higher levels, where vertical movement is apparent. It is therefore possible that with reference to the latest (uppermost) Precambrian rocks of Wādi Ghabar and the Inda Ad Series, no effective reorientation of the primary eastwest stress has occurred.

Postulation of east-west stress as the controlling factor in basement tectonic rocks must be reconciled with the later fold structures of E.A.P., where the folds of the Hadramawt arch, expressed in Eocene sedimentary strata, trend east-northeast to east. Beydoun (1961) regarded this feature as due to warping and possibly resulting from regional compression connected with some transcurrent movement along the Gulf of Aden. The dips on the flanks of this arch are very low-generally about $1^{\circ}$. It seems equally possible that the arching is due to faulting and flexuring connected with the Gulf of Aden graben, essentially as outlined by Wissmann, Rathjens, and Kossmat (1942). Certainly much of the normal faulting on Gulf of Aden lines in W.A.P., which has led to the preservation of tilted blocks of Jurassic and Cretaceous strata in basement-rock areas, is attributed to tension accompanying the later phases of the formation of the Gulf of Aden.

It seems clear that although the Gulf of Aden rift is here considered to be alined along a compressional shear zone of ancient origin, the latest manifestations of rift formation are of tensional type. Since Oligocene and Miocene times, and probably since Late Jurassic times, movements in the Gulf of Aden have been epeirogenic. In this movement, the fault zone of the Gulf of Aden appears to have become depressed relative to the intermittently rising plateau areas on either side of the Gulf.

\section{SUMMARY OF GEOLOGICAL HISTORY}

The following sequence of events is suggested for the western part of the Aden Protectorate:

1. Deposition of sediments, probably upon a planed surface of older gneiss, accompanied by volcanic activity.

2. Intrusion of mafic igneous rocks.

3. Folding and regional metamorphism of sedimentary and mafic igneous rocks to form the Aden Metamorphic Group, accompanied by syntectonic granite invasion, granitization, and migmatization. The metamorphism was mainly of mesozonal type, reaching grades appropriate to the almandine-amphibolite facies.

4. Intermittent uplift of the region.

5. Intrusion of intermediate to mafic plutonic rocks, mainly dioritic, followed after a short interval by intrusion of calc-alkaline granite. Production of contaminated rocks. (In E.A.P. approximately 
contemporaneous extrusion of andesitic volcanic rocks occurred.)

6. Major phase of silicic and mafic dike intrusion.

7. Uplift and denudation of the region and deposition of sediments so derived in fairly local basinal areas. These deposits are represented by the Ghabar Group of E.A.P., but apparently are not preserved in W.A.P.

8. Widespread epizonal metamorphism mainly characterized by deformation, shearing, cleavage, and cataclasis.

9. Planation of basement rocks, followed by deposition of lower Paleozoic sediments. (This stage is particularly conjectural and based on data from adjoining regions.)

10. Intrusion of posttectonic calc-alkaline granites, some of which are dated by radioactivity methods as of Cambrian age. Certain mafic plutonic intrusions may have been emplaced at this stage.

11. Phase of mainly mafic dike intrusion.

12. Widespread pre-Jurassic denudation and planation. The time or times of this planation cannot be closely defined.

13. Deposition of Jurassic and Cretaceous sediments, which are separated by an unconformity or disconformity. Cretaceous rocks may rest directly upon basement rocks.

14. Volcanic activity in the southwest of the region, resulting in formation of the Aden Trap Series of Late Cretaceous to Tertiary age. Intrusion of alkalic granite and of silicic and mafic dikes.

15. Deposition of Paleocene to lower Eocene sediments in the east of the region. A disconformity separates these from underlying Cretaceous rocks.

16. Volcanic activity resulting in the Aden Volcanic Series, of late Miocene or Pliocene to Recent age.

17. Formation of superficial deposits, terraces, raised beaches, and dune sands, from Pliocene and Pleistocene times onward.

Certainly since Mesozoic time and probably since the end of the Precambrian, the region has undergone intermittent epeirogenic movements, which continued until Recent time and were associated with faulting. Faulting is probably of ancient origin with repeated rejuvenation along old trends. A phase of faulting in the Red Sea trend dating from at least Late Cretaceous until late Eocene time is recognized. A main phase of faulting in the Gulf of Aden trend dates from early Miocene time.

\section{ECONOMIC GEOLOGY GEOCHEMICAL PROSPECTING}

Geochemical prospecting (as defined by Hawkes, 1957 ) is a method of mineral exploration based on systematic measurement of one or more chemical properties of a naturally occurring material, the purpose of which is to define areas where the chemical pattern, known as a geochemical anomaly, indicates the presence of ore minerals. The chemical property normally measured is the trace content of various metallic elements and the naturally occurring material may be rock, soil, wadi sediment or water.

Two kinds of geochemical anomalies are (a) primary, of deep seated origin, resulting either from local variations in original rock composition or from impregnation of rocks by mineralizing fluids, and (b) secondary, of superficial origin, resulting from weathering of rocks and ores in situ and of material dispersed from its original source by gravity or running water. Anomalies of the secondary type were sought during the 1961-62 survey, which involved sampling the finer fractions of transported wadi sediments.

In the Protectorate, mechanical disintegration is predominant, causing oxidized ore to be released slowly as the rock weathers. Slope wash carries the metals, along with other soil materials, into nearby wadis where they are incorporated in the alluvium and moved downstream by occasional floods. Owing to the soft nature of most oxidized ore minerals, they are susceptible to abrasion; sampling of the finer fractions of wadi sediments thus offers the best prospects of detecting metal concentrations, but a rapid fall off in values away from an ore body may be anticipated in view of the lack of running water. In an investigation of an outcropping copper ore in an arid part of the United States (Lovering and others, 1950), anomalous values could be detected in alluvium more than 1 mile below the ore body, although the copper decreased from $6,500 \mathrm{ppm}$ (parts per million) over the ore body to $650 \mathrm{ppm}$ only 500 feet downstream.

\section{SAMPLING}

During the course of the 1961-62 survey, 308 samples of -80 fraction material were collected from drainage channels at fairly regular intervals along the route, depending on the availability of suitable sampling sites. Where the road crossed small wadis, these were sampled; where it lay along the major wadis, as was frequent, tributary wadis on either side were sampled. The sampled wadis had in common a small catchment area of a few square miles-which could be defined on the aerial photographs-where the effects of possible outcrops of mineral veins or ore bodies would not become to diluted by the addition of large volumes of alluvial material.

\section{RESULTS}

Values generally were low, indicating a weak dispersion of the elements; $;$ no samples showed very high 
values, but areas could be delimited showing a relatively higher content of certain metals. Of particular interest were the following areas which showed relatively high values for a combination of elements:

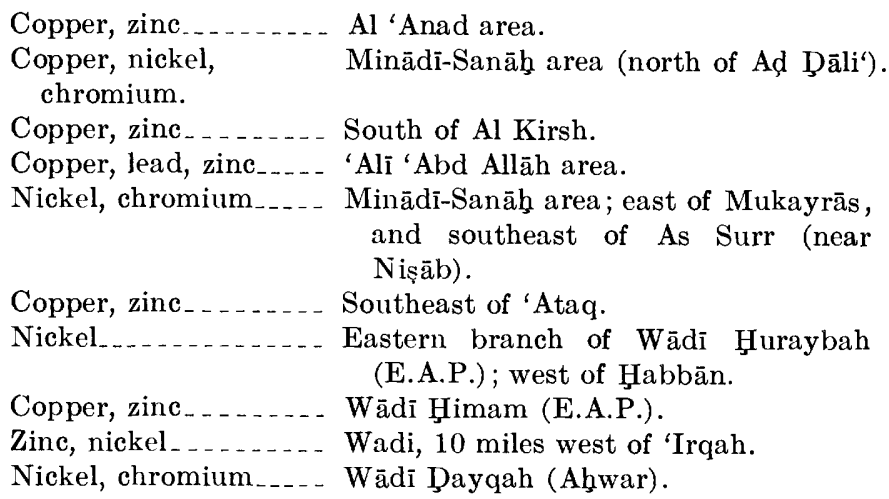
and southeast of As Surr (near Nișāb).

Copper, zinc ........ Southeast of 'Ataq.

Nickel.............. Eastern branch of Wādi Huraybah (E.A.P.); west of Habbān.

Copper, zinc . . ..... Wādī Himam (E.A.P.).

Zinc, nickel . . . . . . . . Wadi, 10 miles west of 'Irqah.

Nickel, chromium_.... . Wādī Ḑayqah (Ahwwar).

\section{INTERPRETATION OF RESULTS}

One of the principal problems in interpreting the data is to distinguish geochemical anomalies from dispersion patterns of no economic significance. Certain empirical parameters can be applied which are helpful in identifying and interpreting the anomalies. These involve considerations of (a) the range of nonsignificant variations in the background, (b) the threshold between nonsignificant and anomalous values, and (c) the homogeneity of the anomalous pattern. Unfortunately, little work has been done on dispersion patterns under an arid weathering regime such as prevails in the Aden Protectorate, and guidance cannot be obtained from experience elsewhere. Normally, geochemical data obtained in areas where the equilibrium has not been upset by the presence of a mineral deposit lie within statistically well-defined limits; patterns of variations may occur, but still lie within this background range. In interpreting the geochemical pattern of an area containing anomalies, it is usually possible to select a certain limiting cutoff or threshold value below which the variations represent background effects and above which they may have significance in terms of possible ore. No hard and fast rules concerning the threshold value can be established, as the geochemical factors may be different in each particular area. In the Aden Protectorate, therefore, it is doubtful what values above the average should be taken as being beyond the background variations and of significance in terms of ore bodies. Copper content, for example, was normally in the range 5-25 ppm: at four localities values of 45 $\mathrm{ppm}$ were obtained, at one locality a value of $50 \mathrm{ppm}$, and at another, $65 \mathrm{ppm}$. For nickel, normal values were 15-35 ppm: one locality showed $65 \mathrm{ppm}$; two, 75 $\mathrm{ppm}$; and one, $175 \mathrm{ppm}$.

To set these figures in perspective, the copper content of igneous rocks ranges between 10 and about $90 \mathrm{ppm}$.
A workable copper ore would give values of about $10,000 \mathrm{ppm}$, which would be reduced to the order of a few hundred parts per million in the soil cover. The nickel content of igneous rocks ranges from about 4 $\mathrm{ppm}$ to more than $100 \mathrm{ppm}$; a nickel ore could give values as high as $15,000 \mathrm{ppm}$, and typical values in the soil cover might again be several hundred parts per million, depending on the distance of the sampling points from the source of the metal; in an arid environment, values generally would be expected to fall rapidly with distance.

It was hoped that reconnaissance sampling might give some indication of higher-than-average values for certain metals associated with particular rock types or suites of rocks, which could be interpreted as indicating a metallogenic province. The results obtained did not point to this, and where relatively high values were obtained, it was not clear whether they were due to the presence of a locally enriched metal facies or whether an outcrop of small veins or ore bodies was responsible.

At this stage it is not possible to distinguish between these possibilities with any certainty. Seventy-nine selected samples were reanalyzed in an attempt to discover whether the metal values represented free ions or ions adsorbed onto clay minerals, or alternatively, whether the bisulfate method employed was releasing metal ions held in the lattices of silicate minerals. The method used was to shake the sample with an aqueous buffer and dithizone; the color of the dithizone layer was then compared with standards to give "coldextractable" copper and zinc values.

The values in general were very low, and the background of less than $1 \mathrm{ppm}$. was not detectable. The relatively higher values of 3-4 ppm actually obtained generally endorsed the anomalies shown by the standard method, which gave "total" metal. In one or two samples, values for cold-extractable metal were obtained when the total content was given as zero. This is explained by the different limits of detection of the two methods: in the total-content method, less than 5 ppm was reported as zero.

Experience has shown that values obtained by the cold-extractable method may be expected to be about 10 percent of the total content, but in view of the low overall total metal content, the fact that the coldextractable values are close to the limits of detection renders any inference drawn from them a matter of doubt. The cold-extractable results, however, represent free metal ions, or those adsorbed onto clays and thus point to actual mineral outcrops in the vicinity. The geochemical results can therefore be said to point out certain areas of metal interest which should receive further detailed exploration combined with more in- 
tensive geochemical sampling, preferably on a grid pattern.

\section{WADI CONCENTRATES}

Heavy-mineral concentrates were obtained from 111 samples of wadi sediment by panning, in water, approximately 1 cubic foot of material.

Under the climatic conditions obtaining in most of the more humid parts of the world, a sorting action occurs when rock debris is moved by running water, and a separation of the particles takes place according to their specific gravity. Heavier grain, which would normally include minerals of economic interest, tend to collect toward the base of the sedimentary column, in pockets and stringers, close to the bedrock forming the floors of the water channels. These are known as the pay gravel or pay streak. Under the weathering regime in the Aden Protectorate, soil and rock debris are swept from the higher ground by torrential flash floods and carried down the wadis by currents of such velocity that little sorting action is able to take place. Furthermore, owing to the high permeability of the wadi sediments, surface water penetrates rapidly, with the result that such floods are checked quickly, limiting the distance of travel and the facility for sorting.

In the field, the wadi sediments generally consisted of a melange ranging in size from boulders up to 5 feet in diameter down to fine sand and silt sizes. No defined pay streak appeared to be developed; but pitting and augering in this type of material presented practical difficulties, and this point has not been thoroughly investigated. Heavy minerals in the form of black sand appeared to be associated with all grades of material, but when concentrated in the sand-size fraction, this was panned to provide a sample for laboratory examination.

The samples were examined in detail by the Mineral Resources Division of Overseas Geological Surveys, with the object of (a) ascertaining whether minerals of economic value existed in the source area and (b) assisting in interpreting the geology of the area.

The field concentrates were separated in a heavy liquid (tetrabromethane) to obtain a sink fraction free from coarse quartz and feldspar, as minerals of economic interest are normally confined to the higher ranges of specific gravity. The heavy-mineral fraction was screened through 30,60 , and 120 British Standard sieves to obtain a rough guide to the grain-size distribution and to facilitate later examination with the binocular microscope. The sized products were separated into strongly, moderately, and weakly magnetic fractions to aid mineral identification and to provide a basis for semiquantitative estimates of the heavy-mineral content. This was determined by estimating the per- centage of every mineral in each of the four magnetic fractions and then combining the results to obtain an overall value. The fine-sand size fraction was normally used for this as it was found to give an average composition for the sample as a whole. Although the analyses were mainly concerned with the heavy minerals, a few notes were added on the light fractions which invariably contained a high proportion of fresh feldspar grains; this is to be expected in arid climatic conditions.

\section{HEA VY-MINERAL CONTENT}

In general, the heavy-mineral fractions from the wadi concentrates are silicate assemblages. Hornblende, pyroxene, and magnetite are the principal constituents and are usually accompanied by smaller amounts of epidote and garnet, scarce sphene and apatite, and traces of zircon, rutile, and tourmaline.

\section{PRINCIPAL FERROMAGNESIAN MINERALS}

With the exception of samples from the Aḍ Dāli' area from Cretaceous volcanic rocks and samples from Wadi Hajar and other wadis to the east which drain areas of older volcanic and sedimentary terrain, hornblende is common to abundant in almost all the concentrates. In general, it is a dark-green variety and shows prismatic faces, but a brown hornblende commonly is associated with the basaltic lavas. In some samples the hornblende is accompanied by pale-green to almost colorless tremolite-actinolite, mostly in euhedral prismatic crystals. The colorless type is most abundant southwest of Lawdar, and smaller amounts occur north of Ahwar; it is probably of metamorphic origin in most places, and, in fact, occurs in samples with high contents of garnet.

Biotite occurs in many heavy-mineral fractions but rarely in large amounts. Samples collected between Lawdar and Al Mahfid and from Al Mahfid south to Abwar contain the highest concentrations. Muscovite is noted in two samples only, and in both is associated with kyanite; however, muscovite occurs widely in the field. Pyroxene is common and is normally either olive-green to brown augite or diopsidic augite, or green to pale-green diopside. The augite commonly occurs in fine-grained euhedral crystals, associated with other materials from volcanic rocks, and is generally of volcanic origin. Most of the diopside appears to be of metamorphic origin but the optics of the two species overlap. In the Al 'Anad-Aḑ Dāli' area olivegreen to brown augite is as much as 60 percent of the sample, and is present in the volcanic rocks around Ghayl Barbar in the extreme west of the Western Protectorate. It is scarce between Al Kirsh and Dār Rahbān and absent from the area east of Lawdar. In the immediate vicinity of Müdiyah, just east of Lawdar, however, a pale-green to colorless diopside is the major constituent. Pale- to dark-green augite is again fairly 
common in the Wādī Hajr-Wādì al Ghabar area and scarce around Al Mukallā. In the wadis west of 'Irqah, small amounts of pale-green to colorless diopside are present, and north of Ahwar augite is again common. Aegirine is present in samples from the $\mathrm{Al}$ 'Anad granite area. Orthopyroxene of about hypersthene composition occurs in several samples, but only in trace amounts except for two samples from near Bayhān; clinopyroxene is generally absent in these concentrates.

Olivine occurs in samples containing a more mafic mineral assemblage and is commonly accompanied by particles of volcanic origin, for example, grains of olivine basalt, anorthoclase, bipyramidal quartz, and composite grains of augite and magnetite. Traces of colorless olivine are in samples from the Ad Dāli'Al Musaymir area, from Ghayl Barbar, and from the Wādi Hajr area of older volcanic rocks; appreciable amounts of augite are also present. Olivine is a major constituent of a sample collected near the basalt flow north of Ahwar and is a minor constituent throughout Wādì Aḩwar.

Magnetite and ilmenite are widespread and remarkably fresh in appearance, although the magnetite in places shows alteration to martite. Ilmenite is usually a minor constituent, but in euhedral or rounded grains, and the two minerals are often difficult to distinguish by eye. The magnetite commonly is titaniferous, and the presence of hopper faces is a characteristic feature of many of the grains.

Garnet occurs in most samples but commonly in minor amounts. It varies from pink to orange, even in the same concentrate. All grains examined in oils proved to be almandine, index of refraction about 1.80, and most were weakly to moderately magnetic; all the garnet is probably of metamorphic origin. The only concentrates containing considerable amounts of the mineral come from Wādi Huraybah and its tributaries and consist of a mixture of garnet and magnetite. A few percent of garnet is recorded from Wādi Hasan, between Mūdiyah and Al Qulaytah, throughout the 'Ataq-Bayhān area, and from the Wādi Ahwar-'Irqah area.

Epidote occurs in almost every sample and in greatest amount in the eastern half of the area. West of a line from Ad Dāil' to Aden it is scarce or absent. It is common to abundant between Wādi Hajr and Burūm, north of Al Mukallā, and in Wādì Aḩwar.

Epidote is commonly well crystallized and in many places occurs in deep green transparent euhedral grains, but most samples contain pale-yellow to yellowishgreen granular particles which have the appearance of epidotized feldspar. Some larger composite grains represent epidosite.

\section{COMMON ACCESSORY MINERALS}

Sphene and apatite are widespread, but usually in scarce or trace amounts, and seldom comprise more than 5 percent of the heavy-mineral concentrate. There appears to be an antithetic relationship between the two minerals and a sympathetic relationship with the hornblende content.

The greatest concentration occurs in the Al Kirsh area which contains a syenitic mineral assemblage. Here, the sphene, which is generally the more abundant of the two minerals, comprises as much as 15 percent of the heavy-mineral concentrate. Samples from the Al 'Anad area which contain an alkalic syenite assemblage are notably rich in apatite, as are the hornblende-rich samples from Wādī Hasan and Wādi Raybān, and from Wādī Ahwar.

The sphene generally occurs in flattened grains which contain a large number of small inclusions but commonly show crystal faces. It may vary appreciably from pale yellow or colorless to deep orange brown. Much of the sphene may be of metamorphic origin, in particular from metamorphosed igneous rocks. This origin could also be true for the apatite, but apatite in many places occurs in perfect hexagonal prisms which may even show terminations.

Sphene concentrates, separated from samples in which this mineral appeared in different associations and in slightly different shades of color, were all found to contain minor and somwhat variable amounts of niobium and yttrium when examined by X-ray fluorescence methods. A brown sphene from near $\mathrm{Al}$ Qulaytah contained the most niobium and a yellow type from Al Kirsh contained rather less, but the differences were probably not sufficiently pronounced to be of practical significance.

Zircon, tourmaline, and rutile are common accessory minerals but vary greatly in type and amount and cannot be directly related to any specific rock types. They generally occur in euhedral crystals, but in samples from sedimentary areas the grains are well rounded, abundant, and accompanied by appreciable amounts of rounded polished grains of leucoxene.

The characteristic cubic grains of goethite pseudomorphs after pyrite are common everywhere but seldom in more than trace amounts. Fresh grains were found east of Mukayrās.

\section{OTHER MINERALS}

Most of the staurolite, occurring in pale-yellow anhedral grains with distinct pleochroism, was found in a belt trending west-northwest from Wādi Haraiba to Ra's ar Rujaymah. Neither staurolite nor kyanite was found in sufficient quantity to suggest the occurrence of major kyanite or staurolite schists or gneisses. (Staurolite schists were seen in the field.) 
Dolomite was found in samples from Wādī Dayqah, north of Ahwar, and in trace amounts from a locality 14 miles east of As Surrah. The grains are well crystallized and transparent and show a pronounced rhombohedral cleavage.

Barite is present in some wadi concentrates. It is a minor constituent in samples from Wādi al Ghabar and, in larger amounts from north of Al Mukalla. Celestite was found in four samples but is not likely to be of economic interest. The mineral occurs in clusters or radiating groups of fine needles or prismatic grains which suggest either a product of subaerial weathering or possibly low-temperature vein deposits.

Fluorite was identified in four concentrates from different areas. None of the more common accessory minerals of fluorite-bearing veins was found: lepidolite, topaz, amblygonite, and cassiterite were sought but not detected.

Spinels (excluding magnetite) were present in several samples, especially those containing olivine, but as a very minor accessory. In four samples the mineral proved to be chromite (see later discussion), and one concentrate contained picotite or pleonaste.

The ilmenite in the wadi concentrates occurs in black lustrous grains which are generally fresh and little altered. Some samples, however, contain pale-yellow to brown or buff-colored nonmagnetic grains which are clearly alteration products of ilmenite and rich in titanium. These have been reported as leucoxene, and several grains examined with $\mathrm{X}$-ray fluorescence show a $\mathrm{Ti} / \mathrm{Fe}$ ratio about 15 times higher than ordinary ilmenite. The distinction may be significant as the mineral occurs in rounded polished grains, generally accompanying rounded grains of zircon, tourmaline, and rutile, and it is thought that these may have come from the heavy-mineral residues of former sedimentary or metasedimentary rocks.

\section{MINERALS OF POSSIBLE ECONOMIC INTEREST}

With the exception of a few magnetite sands, of negligible value in the localities recorded, the wadi samples revealed little evidence of economic concentrations of minerals. In fact, under the climatic conditions prevailing and those of the geologically recent past, there has been little sorting action by the streams and rivers, and it is unlikely that placer concentrations will be found. Economic minerals released from rich vein deposits are liable to be swamped by an influx of barren material from neighboring rocks, or lost in the general movement of waste down hill slopes and wadis. Dispersion may be accelerated by wind action; also, the sand fraction of most wadi concentrates is fine grained. These conditions may account for the fact that, although a variety of rocks was collected from outcrops throughout the area, the mineral assemblages of samples collected from widely scattered localities are remarkably similar; differentiating one sample from another often depends on trace amounts of the less common minerals. As an illustration of this, a concentrate was taken from a very small wadi at the foot of a vein containing galena that cropped out in metamorphosed sedimentary rocks in the wadi side; the mineral assemblage, however, consisted of the usual fine-grained mixture including hornblende, magnetite, epidote, pyroxene, sphene, and apatite, and no leadbearing minerals could be detected.

Minerals characteristic of mineralized granites are practically absent and, with the possible exception of fluorite, there seems to be no hydrothermal mineral deposits. Barite, however, occurs in a number of samples and appears to be widespread in the Wādi al Ghabar area. Small amounts of pyrite are commonplace, but in the wadi concentrates these are completely altered to geothite.

The presence of fairly large grains of monazite at Múdiyah and of radioactive zircon from the granite between Mukayrās and Marta'ah indicates that a further search for radioactive minerals in these areas might be worthwhile.

Traces of chromite were identified in a few samples, notably just east of Dār Rahbān, and its presence was reflected in a relatively high chromium content of a sample taken for geochemical analysis.

Garnet constitutes a large portion of two samples from Wādì Gharīsh and if found in quantity this mineral would be of economic interest.

West of Lawdar and east of Mūdiyah, well-formed crystals of titaniferous magnetite, with hopper faces, were found in abundance. They were probably derived from metamorphic rocks and their source rocks might prove of interest.

\section{MINERAL RESOURCES}

Apart from the minerals mentioned below, asbestos, barite, kaolin, talc, and tourmaline were seen. That none was of commercial interest is due to small extent or poor quality. Lignite in E.A.P. was described by Little (1925), who also recorded bauxite in E.A.P. Little's bauxite-bearing section at 'Arf ad Dỉk was examined, but no bauxite was recognized.

\section{BEACH SANDS}

Beach sands which on field tests appeared to be of potential interest were sampled in two areas. Results of laboratory analysis of a sample $(\mathrm{A} / \mathrm{B} / 8)$ from the mouth of Wādi Hajr, E.A.P., are shown in table 5. 
TABLE 5.-Analysis of beach sand (sample A/B/8), Wādī Hajr, Eastern Protectorate

\begin{tabular}{r|r|r}
\hline British standard mesh & $\begin{array}{r}\text { Screen analy- } \\
\text { sis, in percent }\end{array}$ & $\begin{array}{r}\text { Percent heavy- } \\
\text { mineral con- } \\
\text { tent (specific } \\
\text { gravity }>2.96)\end{array}$ \\
\hline+60 & 0.3 & 45 \\
\hline $60+85$ & 8.0 & 60 \\
\hline$-85+120$ & 47.4 & 89 \\
\hline $170+170$ & 7.6 & 99 \\
\hline-240 & .1 & 99 \\
\hline Total & 100.0 & 91 \\
\hline
\end{tabular}

The composition of the total sample, based on grain count, was:

\begin{tabular}{|c|c|}
\hline Heavy minerals: & Percent \\
\hline Magnetite _........ & 35 \\
\hline Ilmenite _. _ . . . . & 26 \\
\hline Zircon & 19 \\
\hline Rutile_.......... & 4 \\
\hline Pyroxene . . . . . . . . & 3. 4 \\
\hline Epidote $\ldots \ldots$ & 1.3 \\
\hline Monazite & .6 \\
\hline Garnet_.......... & .5 \\
\hline Olivine $\ldots \ldots \ldots$ & .2 \\
\hline Others $\ldots \ldots \ldots$ & 1. 3 \\
\hline $\begin{array}{l}\text { Total heavy } \\
\text { minerals }\end{array}$ & 91.0 \\
\hline Light minerals_......... & 9.0 \\
\hline
\end{tabular}

The ilmenite and magnetite were not counted separately, but the proportions of each were assessed by an acid leaching test. This fraction also contained a little hematite and secondary iron oxide or martite. The other heavy minerals not listed above consisted mainly of brown to blue tourmaline, with traces of sphene and hornblende and an occasional grain of staurolite.

The light fraction was mainly composed of about equal amounts of calcite and quartz.

The composition of heavy-mineral fractions from the total sample and from each screen size was shown in table 6 . The ilmenite content remains fairly constant, and the magnetite content decreases with decreasing grain size. The amount of +60 and -240 material was almost negligible, and no analysis of these fractions was attempted. It can be noted that zircon content increases markedly in the finer sizes.

In summary, this material may be described as a heavy-mineral beach sand containing more than 90 percent of heavy minerals, of which about 50 percent are the useful minerals ilmenite, zircon, rutile, and monazite. It is well graded, the grains are clean and well rounded, and the content of ferromagnesian silicate minerals is small. The intrinsic value of such a
TABLE 6.-Composition of heavy-mineral fractions in beach sand, Wādì Hajr, Eastern Protectorate

\begin{tabular}{|c|c|c|c|c|c|}
\hline \multirow{2}{*}{ Heavy minerals } & \multicolumn{4}{|c|}{$\begin{array}{l}\text { Screen fractions (British Standard mesh), } \\
\text { in percent }\end{array}$} & \multirow{2}{*}{$\begin{array}{l}\text { Total } \\
\text { sample }\end{array}$} \\
\hline & $-60+85$ & $-85+120$ & $-120+150$ & $-150+240$ & \\
\hline 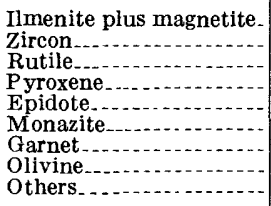 & $\begin{array}{r}72 \\
7 \\
3 \\
10 \\
4 \\
\text { Trace } \\
1 \\
1 \\
2\end{array}$ & $\begin{array}{c}72 \\
12 \\
4 \\
6 \\
2 \\
\text { Trace } \\
1.4 \\
2 \\
2\end{array}$ & $\begin{array}{c}63 \\
28 \\
5 \\
1 \\
.6 \\
1.3 \\
\text { Trace } \\
1\end{array}$ & $\begin{array}{r}41 \\
51 \\
5 \\
\text { Trace } \\
\text { Trace } \\
3 \\
\text { Trace } \\
\text { Trace } \\
\text { Trace }\end{array}$ & $\begin{array}{l}66 \\
22 \\
4 \\
3.7 \\
1.4 \\
1.4 \\
.6 \\
.2 \\
.7\end{array}$ \\
\hline Total_..... & 100 & 100 & 100 & 100 & 100 \\
\hline
\end{tabular}

sand, however, is small, the principal salable constituents being low-priced minerals. The contained magnetite, which probably would not be salable, is rather high, and the content of the more valuable minerals, rutile and monazite, is low. Utilization of such a sand could be considered only if large tonnages (of the order of hundreds of thousands of tons) were available.

A brief examination of the surrounding area did not suggest that any such tonnage was present near the Wâdi Hajr mouth; however, the combined coastline E.A.P. and W.A.P. approaches 700 miles in length, and deposits of similar character but larger size may well exist at other places. The coastal plain is of varying width, and the winnowing effect of the monsoon winds may have a significant effect in concentrating the heavy-mineral fractions.

The second sample $(\mathrm{A} / \mathrm{B} / 10)$ was taken from a much larger area of dune sands on the shore of Abyan at the junction of the road from Zinjibār and the coast road to Aden. It was a light-gray medium sand, with size analysis as follows:

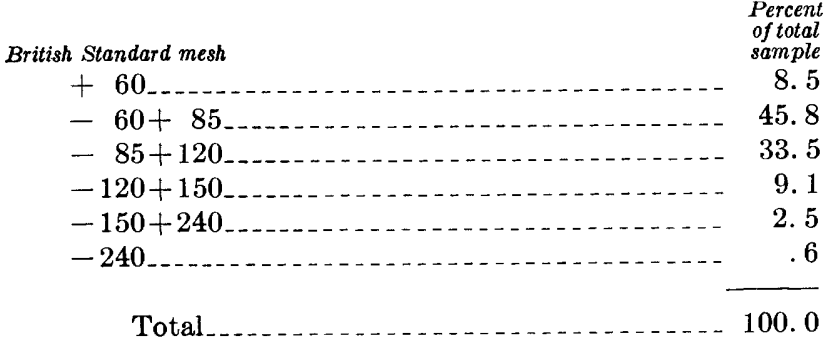

The content of heavy minerals having specific gravity greater than 2.96 was 27 percent distributed as follows:

\begin{tabular}{|c|c|}
\hline $\begin{array}{l}\text { Hornblende } \ldots \ldots \ldots \\
\text { Clinopyroxene }\end{array}$ & $\begin{array}{l}\text { Abundant. } \\
\text { Common. }\end{array}$ \\
\hline $\begin{array}{l}\text { Pyroxene-magnetite (com- } \\
\text { posite grains). }\end{array}$ & Fairly common. \\
\hline Epidote $_{\ldots}$ & Sparse. \\
\hline Biotite & Scarce. \\
\hline Garnet $\ldots \ldots$ & Do. \\
\hline Sphene..... & Do. \\
\hline
\end{tabular}




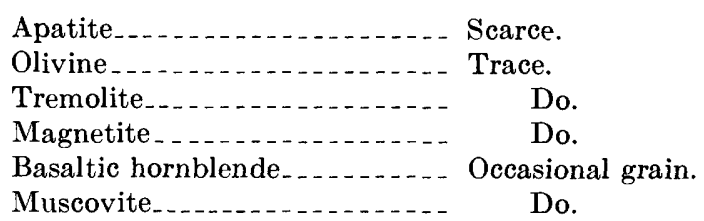

The light fraction consisted mainly of feldspar (mostly plagioclase) with subordinate quartz and a little biotite, calcite, and shell fragments. The grains were fresh and showed little rounding. This sample, therefore, contained only 27 percent of heavy minerals, and none of any economic interest.

\section{BUILDING STONE}

Plentiful supplies of building stone are quarried from the volcanic rock of Aden Colony. More decorative types of building stone are available in the interior of the Protectorate; some of these are of very pleasing appearance, such as certain types of porphyritic volcanic rocks, granitic rock, and blue, black, and white marbles. The source nearest to Aden is northnorthwest of Lahj in the Al 'Anad area, where rocks of the types mentioned, together with others such as basalt and sandstone, are available. To the east of Aden, limestone is quarried at Khanfar, Abyan.

Other major centers in the Protectorate are within reach of a varied assemblage of building stone and road metal.

\section{COPPER MINERALS}

Occurrences of copper minerals were recorded as follows:

'Irqah.-At a locality 14 miles northwest of 'Irqah, approached by a major but apparently unnamed wadi, small patches of copper carbonate, (malachite) were found in calcite veins cutting granite and schistose basement rocks. The occurrence is of no commercial importance.

Zulm Bā Thalab.-In the northeast sector of Zulm Bā Thalab, some 8 miles west-northwest of Ma'bar, Hajr, malachite was found as encrustations and small patches in serpentinized Precambrian volcanic rocks. The copper mineral is associated with hematite. Both copper and iron ore are in insignificant amounts.

$M a^{\prime} b a r$-About 1 mile south-southeast of the road and wadi crossing at Ma'bar, Hajr, copper associated with hematite was found in serpentinized epidotic rock. A sample submitted for analysis contained 8 percent of copper. The hematite (specularite) forms nearly continuous lenses, generally $3-4$ inches in width, in altered calcitic-limonitic veins, $2-3$ feet wide. In an area of about 50 square yards, 5 such veins were recorded, all striking within a few degrees of northwest. The veins run transversely to, and are exposed in, steep sided gulleys to a depth of 3-4 feet; their continuation in depth was not proved. The maximum exposed length of the veins was 10 feet; weathered overburden conceals their probable further extension. A greenish-blue copper mineral, considered in the field to be mainly malachite, forms encrustations upon and thin ramifying veinlets within the hematite. Further traces of copper impregnating hematite were seen over the area upon hill slopes and in wadi beds.

Laboratory examination showed the predominant gangue minerals to be andradite garnet, calcite, feldspar, and quartz. Copper minerals include finegrained black sulfides, which X-ray examination showed to be intergrowth of chalcocite, digenite, and covellite, with green and blue oxidation products which include malachite, brochantite, and chrysocolla. The identity of the copper minerals was established by X-ray powder analysis. The abundance of andradite suggests that the rock is a contact metamorphic skarn. The copper sulfides are probably supergene, as are the malachite, brochantite, and chrysocolla, and there is no evidence as to the nature of the primary mineral which presumably gave rise to the secondary enrichment copper.

A representative portion $(1 \mathrm{lb})$ of the specimen was crushed and assayed for copper, iron, and precious metals, with the following results:

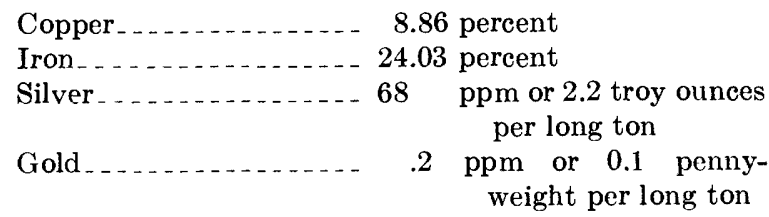

The copper content is comparatively high, but this should not be overrated since the specimen is from a narrow vein: more fieldwork is required to ascertain whether this sample is representative of the overall tenor; the silver content, at current prices, would add about 4 percent to the gross value of the ore. Other constituents indicated by $\mathrm{X}$-ray fluorescence, but of no economic significance, include traces of manganese, barium, strontium, and iodine, and a slight trace of molybdenum.

$W \bar{a} d \bar{\imath}$ al Ghabar.-At various localities in Wādi al Ghabar, mainly within 3 miles north of the Wādi al Ghabar-Mudhaniyah junction, malachite was found encrusting pebbles in volcanic conglomerate and also on quartz fragments. This locality is some 12 miles southeast of Jabal ad Da'liyah where Little (1925) reported hematite with 5 percent of copper.

Geochemical analysis proved relatively high values for copper in samples from Wādi Himam north of Al Mukallā and from the Western Protectorate near Sanāh, Al Kirsh, and 'Alī 'Abd Allāh. With the exception of the Ma'bar occurrence, which on results 
of chemical analysis merits further investigation, the traces of copper mineralization are not important in themselves. However, taken in conjunction with the finds reported by Little (1925), they may suggest the existence of worthwhile deposits, and copper would appear to be one of the more interesting possibilities in the Protectorate. On the basis of the number of known occurrences, the areas between and adjacent to Wādì Hajr and Wādì al Ghabar in the Eastern Protectorate may be considered favorable for more detailed examination, as possibly also the area between Al Mukallā and Wādì Hiimam.

\section{OTHER MINERALS}

Feldspar.-Many of the numerous pegmatites which occur in basement rocks are composed mainly of feldspar, commonly in large crystals as much as 8 inches in diameter. Feldspathic bands and pegmatites sufficiently free of other minerals (such as quartz and muscovite) to be of economic interest occur in numerous localities, but their extent is not such as to warrant commercial exploitation.

Most of the coarser and more continuous outcrops are of potassic feldspar. Fragments of amazonstone were found in Wādī al Jahr, 15 miles east of Aş Şurrah, but their source could not be located.

Garnet.-Garnet is common in many of the metamorphic rocks and in feldspathic pegmatites. The variety most frequently seen is almandine, but andradite and grossularite are also recorded. Garnets of gem-stone quality were not found.

Gypsum-anhydrite.-Extensive deposits of gypsumanhydrite of the lower and middle Eocene Rus Formation occur in the eastern parts of the Protectorate. Of these the most easily accessible is that exposed between Mayfa 'ah and Rudhūm on the west of Wādi Mayfa'ah. The formation consists of massive to bedded gypsumanhydrite interbedded with limestone. Earthy shaly horizons and chert nodules occur. Thus, the deposit is of variable quality.

Rocks of the Oligocene and Miocene Shihr Group, outcropping near the coast to the east and west of $\mathrm{Al}$ Mukalla, also contain horizons of gypsum, gypseous marls, and dolomitic limestone, together with sandstone and shales.

Experiences in Somaliland, where one of the world's largest high-grade gypsum-anhydrite deposits remains unworked within 9 miles of Berbera port, do not encourage optimism concerning exploitation of material in Aden. It may be noted that the Rudhūm deposit would provide the small amount of gypsum required in any production of portland cement.

Ilmenite.-In a tributary to Wādi Ḑayqah, about 5 miles west-southwest of $\mathrm{N}$ ūsah, small patches of nodules of ilmenite were found in quartz veins cutting biotite schists and gneisses. The ilmenite was too disseminated and the aggregate quantity too small to be of importance.

Iron minerals.-Iron mineralization occurs at numerous localities in quartz veins, feldspathic bands, and pegmatite dikes cutting basement rocks. No large deposits of commercial interest were found. Localities in which the more significant occurrences were seen include Al Mājil, southwest of Lawdar (magnetite); 10 miles miles east of Aș Şurrah (hematite nodules in wadi); 12 miles south of Nișāb (magnetite); and 2 miles eastsoutheast of Jabal ath 'Thaniyah (specular hematite in quartz veins). Iron pyrites reported in $\mathrm{Al}$ Wāhidi State and Wādi Jirdān ('Iyādh) is of interest only as suggesting the presence of sulfide ores.

Lead.-About 13 miles north of Ahwar, galena occurs as impersistent veins, about 2 inches wide, in association with partly brecciated quartz and calcite in a weatheredout fault plane cutting basement rocks. It is likely that the galena originated from low-temperature hydrothermal solutions of magmatic origin.

The fault or shear zone, which is $8-12$ inches wide, strikes north across the trend of basement rocks, which here is east. Much of the more easily accessible galena has been excavated by local inhabitants, but traces of the mineral were seen over a distance of about 100 feet where the fault plane is exposed on a steep slope above a wadi bed.

The Mineral Resources Division report on a sample is as follows:

The sample consists of coarse-grained galena, apparently from a veinlet or rib from $3 / 4$ to $1 \frac{1}{2}$ inches in thickness, with only a small proportion of gangue mineral, principally white calcite. A representative portion ( $8 \mathrm{oz}$ in weight) was crushed for analysis and by a qualitative $\mathrm{X}$-ray fluorescence examination was found to consist of lead, predominantly, with traces of iron, silver, copper, and zinc. Quantitative assays showed 70.8 percent of lead and 8.6 troy ounces of silver per ton of ore. These values correspond to a galena content of approximately 82 percent and 12 ounces of silver per ton of lead. At current metal prices the silver content adds only 7 percent to the gross value of the lead in the ore.

A thin crust of alteration products on the surface of the galena, largely cerussite and indeterminate ferruginous material, was shown by X-ray fluorescence examination to contain the same trace element suite as the assay sample and, in addition a trace of molybdenum. The latter is presumably present as traces of wulfenite and is probably an indication of molybdenum in the country rock rather than a primary association of molybdenum with lead.

In basement rocks of granite gneiss and schist 1 mile south of Thirah, small quantities of galena have been reported in quartz stringers and pods. These occurrences are too small to be of commercial importance.

Mica.-Muscovite is a ubiquitous constituent of the pegmatites which occur in many areas of basement 
rocks. Books of muscovite were noted in the following localities.

Wādī Hasan: In Wādī Hasan about 11 miles westsouthwest of Ar Rawdah, thin books of muscovite with inclusions of garnet occur with quartz and feldspar in pegmatites cutting biotite schists. The books are about $1 \frac{1}{2}$ square inches in area.

Wādī Raybān: About 7 miles southwest of Al Mājil, muscovite plates and thin books of about 1 square inch in area are scattered abundantly through pegmatities.

Müdiyah area: Books of muscovite are abundant in pegmatites cutting granite. The books are dispersed and scattered through the dike rocks and the largest seen were about 4 square inches in area.

Four miles west of Nūsah: Muscovite books as much as 6 square inches in area occur in a pegmatite with quartz feldspar.

Wädī 'Abadān, Nişāb: Five miles south of Nişāb, thin books of muscovite as much as 4 square inches in area are scattered through pegmatite dikes cutting granite. The pegmatites are 3-6 feet wide and may be as much as 30 yards long.

Sacìd: Three miles west of $\mathrm{Sa}^{‘} \mathrm{i} \mathrm{i}$, muscovite books as much as 6 square inches in area are abundant in coarse pegmatites cutting biotite schist and gneiss.

Wādī Gharīsh: About 12 miles north of Balhăf, muscovite in books as much as 4 square inches in area, occur sporadically with quartz, feldspar, and red garnet in impersistent pegmatites (fig. 25).

Northwest of 'Irqah: About 14 miles northwest of 'Irqah, muscovite occurs in pegmatite cutting biotitemuscovite schists and granitic and feldspathized rocks. Plates as much as 10 square inches in area were seen.

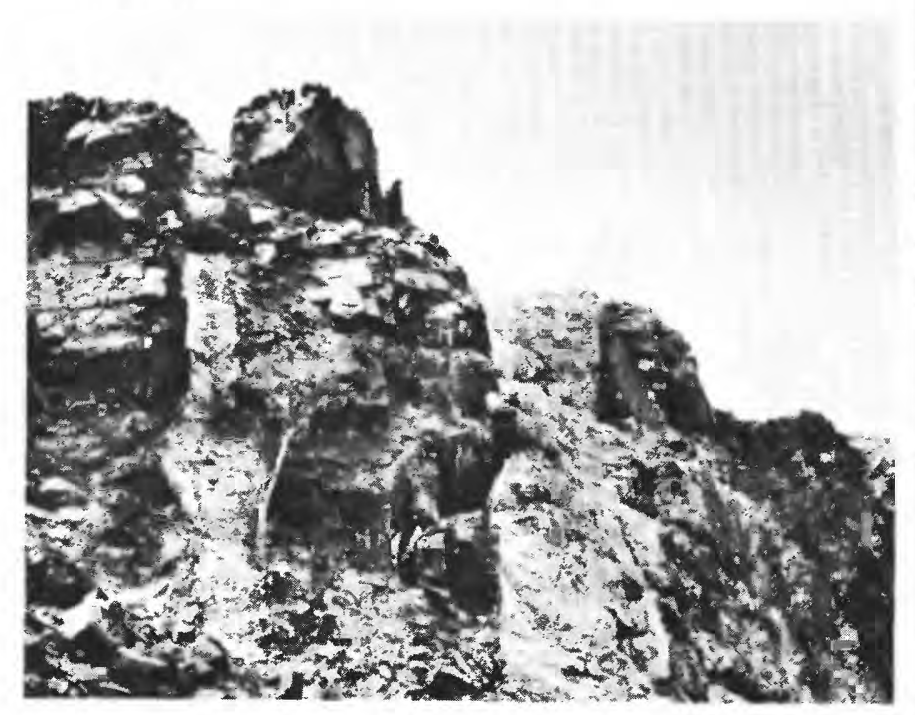

Figure 25.-Pegmatite dikes in quartzite, Wādī Gharìsh.
The most important occurrence of mica is the last named, near 'Irqah. Here muscovite in books 4 inches thick and as much as 10 square inches in area forms a nearly continuous zone about 9 feet wide; it extends the length of a feldspar-quartz pegmatitic body, some 12 feet wide and 30 feet long, which is exposed in a steep cliff face of biotite-quartz-feldspar schist. The pegmatite trends in a direction of $230^{\circ}$. The zone of muscovite books extends in depth to about 9 feet and may continue to greater depths. The books of mica are arranged at all angles commonly mutually at right angles, and the plates commonly are bent and buckled; however, flat plates could be obtained. The sample submitted to the Mineral Resources Division is reported to contain small rhombs of a carbonate mineral (as inclusions in the mica plates).

In the Sa'id occurrence the presence of numerous pegmatite dikes containing abundant, though scattered, muscovite suggests that further examination might possibly disclose larger segregations of mica.

The occurrence 4 miles west of Nussah is close to the Mūdiyah-Nūsah track. The mica was seen in a pegmatite dike about 3 feet wide and 60 feet long, striking east. Again the books are arranged in a decussate manner so that plates tend to be buckled and contorted. The laboratory report states that the white muscovite plates include sporadic crystals of flattened pink garnet.

The mica seen in the Aden Protectorate is not likely to be of commercial interest, firstly because quantity is too small to warrant exploitation, and secondly because that seen in plates large enough to be of interest is generally bent or buckled and contains mineral inclusions.

Quartz.-Massive, opaque, and vitreous quartz is common in the numerous pegmatites and veins of the Protectorate. Well-crystallized forms were infrequently seen, and quartz gem stones were not recorded.

Commercial exploitation of this ubiquitous mineral depends upon an advanced state of general industrialization and is not likely to be worth consideration in the Protectorate.

Rock salt.-Deposits of rock salt are known to occur in salt domes at 'Iyādh (Hayd al Milhs); Ayadim, about 33 miles west-northwest of 'Iyādh; Lai'adin (Jabel at Milh), about 38 miles N. $64^{\circ}$ E. from an Nuqūb, Bayb̧ān (some 50 miles by track from an Nuqūb); Milh Kharwah, about 24 miles N. $12^{\circ}$ E. from 'Iyādh; Milh Maq'ah, about 18 miles N. $10^{\circ}$ E. from Shabwah; Al Mințāq, about 5 miles N. $35^{\circ}$ W. from Șidārah; Șāfir, about 18 miles southwest of Jabal ath Thanīyah, on the Yemen border; Shabwah; Siyal al Milh, about 12 miles northwest of Șidārah. 
The salt domes at 'Tyādh, Lai'adin, and Milbs Kharwah were examined and considered to be of Jurassic age; there is little doubt that the remainder are of the same age.

At Lai'adin massive rock salt is overlain by varicolored shales, bituminous in part, and gypsiferous beds. Toward the surface of the dome, salt is intermixed with fragments and blocks of contorted shale with thin lignitic lenses and bands. The gray shale is in part a paper-thin laminated variety. Well-formed salt crystals line fracture planes in brecciated shale and form stalactitic deposits under cliff faces. The bulk of the deposit is pink to white massive salt.

At 'Tyādh the elongated dome structure is very clear, the peripheral slopes consisting of thin-bedded (lagoonal) limestone interbedded with minor calcareous shales, and evaporitic deposits of concretionary brecciated gypsum overlie salt in the central areas.

At Milh Kharwah massive rock salt forms the center of the dome and thin bands of salt are interlayered with steeply dipping dark bituminous shales. Jurassic limestone again forms the peripheral slopes.

At the time of the authors' visit salt was being worked at Lai'adin and 'Iyādh for local consumption and also for export to Yemen (fig. 26). Probably a number of the other salt deposits are similarly worked, by local labor using simple tools.

It is not thought that the present exploitation of salt deposits can be significantly increased, in view of the difficulty of access to the salt deposits, most of which

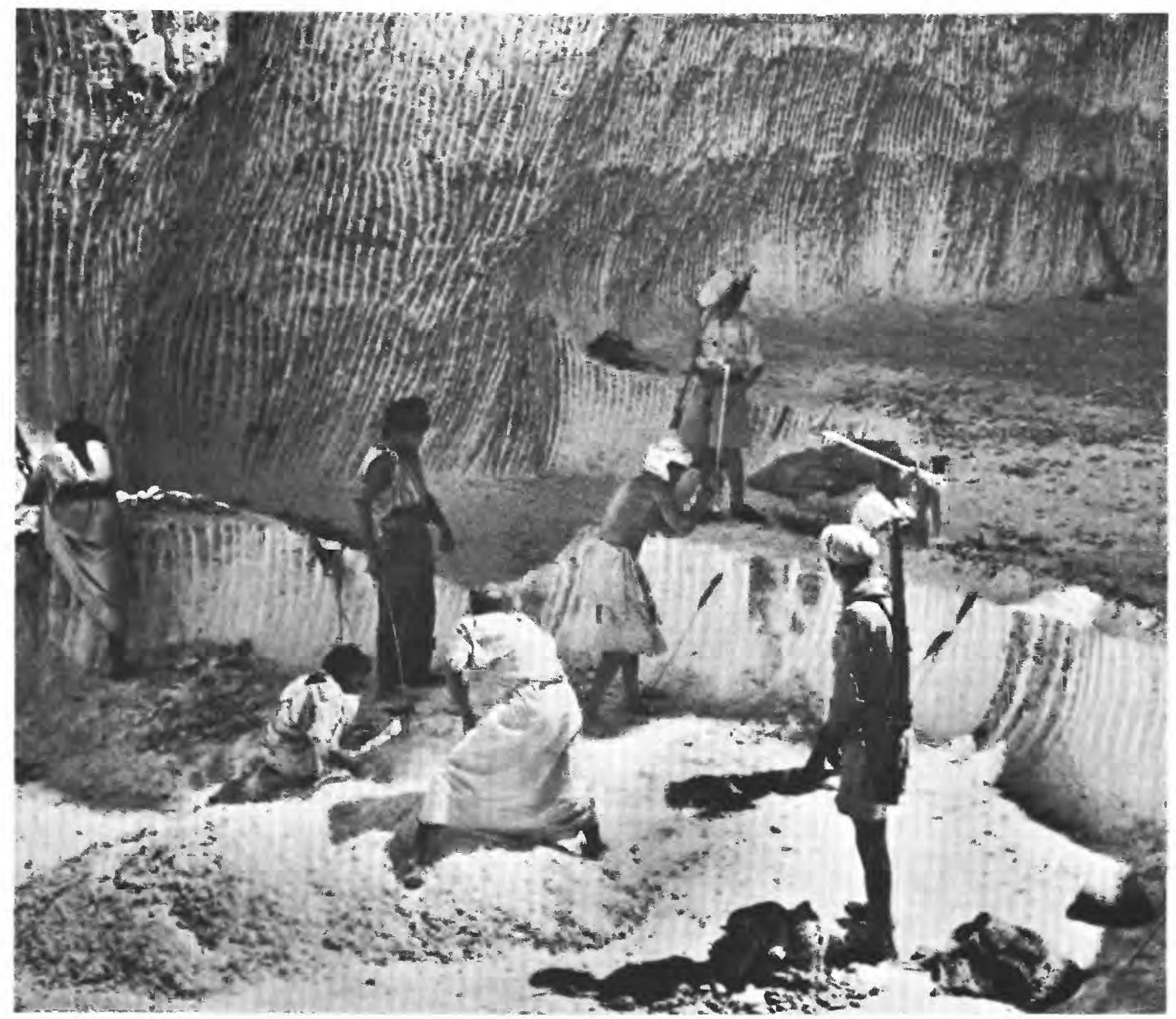

FIGURE 26.-Workers excavating salt at Iaai'adin salt dome. 
lie in or near the Ramlat as Sab'atayn; the poor communications to the coast; and the difficulties of marketing exported salt.

\section{PORTLAND AND OTHER CEMENTS}

The raw mix for portland-cement manufacture usually consists of about 3 parts of predominantly calcareous material (chalk or limestone) and 1 part of predominantly argillaceous material (clay, shale, or river mud). The overriding factor is the bulk composition of the available raw materials, as it is essential that these give a mix correctly balanced in terms of $\mathrm{CaO}, \mathrm{SiO}_{2}, \mathrm{Al}_{2} \mathrm{O}_{3}$, and $\mathrm{Fe}_{2} \mathrm{O}_{3}$. An upper limit to the $\mathrm{MgO}$ content is usually set at 5 percent, as an excess may cause the formation of periclase which may result in the failure of the concrete, through slow hydration. Gypsum is normally added to the clinker at the grinding stage, to control setting time.

To make an initial assessment of the general availability of raw materials for cement manufacture, three localities, selected for easy accessibility, were sampled; these were (a) Khanfar rock, near $\mathrm{Ji}^{`} \bar{a} \mathrm{r}$, Abyan district (sample A58), (b) South-southeast of Dirjāj, compass bearing $40^{\circ}$ to Khanfar rock (sample A267), and (c) Al Mukallā, near road to Al Khalaf police station (sample A262).

Khanfar rock: The sample was taken from a quarry in Jurassic rocks. The exposed section was of bedded dark-brown to gray crystalline limestone and porcellanous limestone, cut by numerous thin calcite veins. The limestone was stained purple in part. Interbedded with limestone were beds about 10 feet thick of yellow-brown to gray paper shales, with ironstone concretions and much fibrous gypsum. The rocks were fractured and jointed.

Dirjāj locality: The sample was taken from Jurassic beds dipping $40^{\circ}$ in a direction of $160^{\circ}$, and estimated visually as about 250 feet thick. The series consists of fossiliferous beds of pink to brown crystalline limestone, about 3 feet thick, interlayered with rubbly, shaly limestone and with marly beds about 1 foot thick. Joint and fracture planes are iron stained and numerous iron carbonate concretions are present. The base of the series is sandy limestone and calcareous sandstone, resting upon a conglomeratic quartzose sandstone some 8-12 feet thick, which in turn rests unconformably upon basement rocks. The Jurassic rocks are considered to be of the Kohlan Formation (Middle to Lower? Jurassic), with upper beds possibly of the Shuqra Formation (Upper Jurassic).

Al Mukallā: The sample was collected from Cretaceous rocks exposed in a cliff face adjoining the road from Al Mukallā to Ra's Al Mukallā, in the vicinity of $\mathrm{Al}$ Khalaf police station. Cretaceous rocks of the Qishn Formation (Barremian-Aptian) here consist of variegated pink-red, yellow-brown, and white, crystalline, porcellanous, and sandy limestone. Field observation suggests that the limestone is dolomitic, at least in part. The rock is iron stained. The Cretaceous beds unconformably upon basement rocks and are overlain by Paleocene limestones.

Results of chemical analysis of the samples from the three localities are shown in table 7 .

TABLE 7.-Composition of limestones, in percent [n.d., not detected]

\begin{tabular}{|c|c|c|c|}
\hline \multirow{2}{*}{ Constituent } & \multicolumn{2}{|c|}{ Dolornitic limestone } & \multirow{2}{*}{$\frac{\begin{array}{c}\text { Argillaceous } \\
\text { limestone }\end{array}}{\underset{\text { Dirjäj }}{\text { A267 }}}$} \\
\hline & $\begin{array}{c}\text { A58 } \\
\text { Khanfar }\end{array}$ & $\begin{array}{l}\text { A262 } \\
\text { Al Mukallā }\end{array}$ & \\
\hline $\begin{array}{l}\mathrm{CaO} \\
\mathrm{MgO} \mathrm{O}_{2} \\
\mathrm{SiO}_{2} \\
\mathrm{Al}_{2} \mathrm{O}_{3} \mathrm{O}_{3} \\
\mathrm{Te}_{2} \mathrm{O}_{3} \\
\mathrm{Ni}_{2} \mathrm{O}\end{array}$ & $\begin{array}{r}35.88 \\
14.97 \\
.69 \\
.62 \\
1.42 \\
\text { n.d. }\end{array}$ & $\begin{array}{r}33.14 \\
18.90 \\
.54 \\
.32 \\
.28 \\
\text { n.d. }\end{array}$ & $\begin{array}{r}34.48 \\
2.52 \\
23.63 \\
5.20 \\
2.45\end{array}$ \\
\hline $\mathrm{K}_{2} \mathrm{O}_{-}$ & .39 & n.d. & \\
\hline Loss on ignition & $\begin{array}{r}\text { n.d. } \\
45.53\end{array}$ & $\begin{array}{l}\text { n.d. } \\
\text { 46. } 53\end{array}$ & $\begin{array}{r}.07 \\
28.28\end{array}$ \\
\hline Total. & 99.54 & 99.80 & 99.71 \\
\hline
\end{tabular}

The average composition of portland-cement clinker shows a $\mathrm{CaO}: \mathrm{MgO}$ ratio of 44 . When the raw material is particularly low in $\mathrm{MgO}$ the ratio may exceed 100 . The ratio's lower limit is 14 , at which point the $\mathrm{MgO}$ content of the clinker approaches the specified maximum (say 5 percent).

Samples A58 and A262 have $\mathrm{CaO}: \mathrm{MgO}$ ratios of about $2 \frac{1}{2}$ and $1 \frac{1}{2}$ respectively. They are therefore completely unsuitable for portland-cement manufacture. It is not possible to calculate a satisfactory clinker analysis from any mixture of these limestones with (a) an orthodox argillaceous material or (b) the argilla ceous limestone, sample $\mathrm{A} 267$. In both, the $\mathrm{MgO}$ content would still be too high.

Sample A267 has a $\mathrm{CaO}: \mathrm{MgO}$ ratio of about 14 . On a loss-free basis, its composition is as follows:

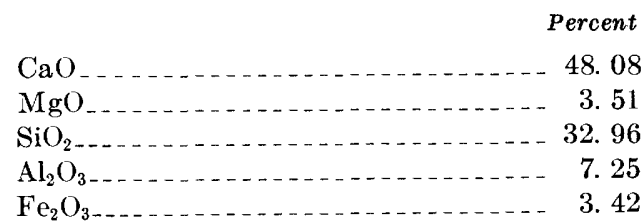

This composition shows a deficiency of $\mathrm{CaO}$ and a corresponding excess of $\mathrm{SiO}_{2}+\mathrm{Al}_{2} \mathrm{O}_{3}+\mathrm{Fe}_{2} \mathrm{O}_{3}$. It could be balanced to provide a reasonable portland-cement clinker composition by adding a material low in $\mathrm{MgO}$ and ranging from pure limestone to moderately 
argillaceous limestone. By adding 120 parts $\mathrm{CaCO}_{3}$ (pure limestone) to 200 parts of sample A267 the $\mathrm{CaO}: \mathrm{MgO}$ ratio increases to 27 . The silica modulus (derived from the ratio of $\mathrm{SiO}_{2}$ to combined $\mathrm{Al}_{2} \mathrm{O}_{3}$ and $\mathrm{Fe}_{2} \mathrm{O}_{3}$ ) is 3.1 , which is rather high, the normal range being from 2.4 to 2.7 . It could easily be reduced by adding iron ore to the raw mix.

The dolomitic limestones A58 and A262 could be used for making magnesian lime, which is acceptable for certain building purposes; being low in silica and alumina, the lime would have negligible hydraulic properties.

The argillaceous limestone A267 would probably give a cementitious product after burning. However, further work would be necessary to determine the performance of such a product.

It is apparent from the foregoing that in the production of portland cement considerable limitations are imposed as to the quality of materials. Economic considerations limit the distance over which raw materials may be carried, and cement works are usually sited accordingly. Thus the production of cement to specified standards, such as would be required to found an export trade or to use in structures of any importance, depends upon finding suitable limestone in an accessible place in juxtaposition with siliceousaluminous material such as clay, shale, or mud.

The easily accessible limestones sampled are not suitable. It may be added that in calcareous sedimentary rocks of Jurassic to Oligocene and Miocene age, important dolomitic beds are known to exist; this suggests that the magnesia content of other Protectorate limestones is likely to be high. Crystalline limestones associated with the basement rocks are also dolomitic in many of the known outcrops. However, especially in the Eastern Protectorate, limestone is present in huge quantities, and it is not improbable that appropriate cement-making materials could be found reasonably close together. The question of transportation would then arise.

The search for appropriate raw material is not made easier by the fact that dolomite and dolomitic limestone are not easily recognized in the field and chemical analysis is therefore essential from the first stages of exploration. From the point of view of competitive commercial production the prospects do not appear to be good.

\section{SUMMARY}

Neither during the 1961-62 survey nor in the course of previous work have mineral deposits been found worthy of further commercial exploitation under the conditions obtaining. In this connection the prevalence of syntectonic granites and granitized rock may be relevant, and few minerals characteristic of mineralized granites have been recorded. Clearly intrusive granite does, however, occur in several areas, and in former Somaliland Protectorate cassiterite deposits have been found in quartz veins, probably associated with intrusive granite of comparable age. Of the minerals found in the Protectorate, perhaps most interest attaches to copper. In view of the large area involved and the comparatively little exploration done, it would be premature to draw firm conclusions as to the presence or absence of important mineral deposits.

\section{WATER RESOURCES}

The Aden Protectorate lies in the so-called arid zone, which stretches from the Atlantic seaboard to the North African coast to Sind in Pakistan, with a discontinuous extension as far east as China. It cannot be properly defined on a climatic basis, but its problems are climatic in origin and stem from the imbalance between water supply and water need. The zone as a whole is characterized by wide fluctuations in precipitation, temperature, and aridity. Rainfall is infrequent, localized, irregular, and often of high intensity; it ranges from less than 1 inch to as much as 20 inches in some years. Temperatures range from freezing to above $130^{\circ} \mathrm{F}$, with low relative humidity. Such factors require a high degree of specialization in plants and animals, and set the pattern of land use.

Water is the limiting factor in agriculture, on which permanent or semipermanent settlement must depend; since the time when these arid areas were first colonized the chief preoccupation has been to conserve and to put to use as much of the limited natural precipitation as possible. Archeological research has shown that many of the now-dead cities of Arabia, formerly thought to have depended entirely on the caravan trade, in fact possessed a highly developed agriculture and even evolved methods for turning the destructive forces of floods to constructive use. The decline of many of these earlier civilizations is now ascribed to political and other factors, and there is no evidence either historical, archeological, or botanical (based on the study of tree rings) to show that the climate has become significantly more arid during the historic period. Such research has proved the occurrence of drought periods, often of many years' duration, but these have not been confined to the arid zone and probably resulted from long-term climatic cycles caused by, for example, sunspot activity. It may well be that no one factor has been responsible for decline of civilizations in the arid zone. The delicacy of the balance between such societies and their environment was precarious and easily upset, and there was far less latitude of action than under other conditions; 
any factor causing unbalance could be disastrous. A program of research into arid-zone problems should therefore be a detailed and integrated product of scientific research rather than a limited assemblage of facts, and the collection of data should be extended over a period broader than the known climatic cycles, that is 20-30 years. Empirical solutions based on short-term investigations may prove to be costly failures.

In the arid zone, runoff is excessive, owing to the high intensity of the rainfall, and flash floods (seil) are the result. The immediate effect of these is to sweep off the soil cover from the interfluves into the wadis and flood plains, where it is deposited or can be artificially induced to collect. Being unleached detritus formed largely by the mechanical breakdown of bedrock, it can, depending on the parent material, provide a very fertile soil when suitably irrigated. Rainfall from a large catchment area, when concentrated in the wadis, is equivalent to precipitation increased several hundredfold and is more than adequate for most farm crops. From the earliest times, therefore, the object of organized agriculture has been to create fields in the wadis and on the flood plains, with a controlled supply of water. Recent plans for agriculture in the Negev desert (Goldschmidt, 1961) based on spate irrigation have shown that the designs of the necessary earthworks, calculated by specialists with the latest technical aids, coincide almost exactly with those evolved in earlier times by methods of trial and error. Such designs call for the overland gravity flow of water from higher ground down to the farmland, if necessary by an elaborate system of interceptors and conveyors with regulators.

\section{IRRIGATION PRACTICE}

Agricultural techniques and the utilization of rainwater and floodwater vary according to position along a given watercourse and have a pattern with many common features in countries throughout the arid zone. In tributary wadis, many of which are steep and narrow, the water must be brought under control from the watershed down. This is done by means of dams of stone or of bushes held in position by large stones, which are built right across the wadi; where the rush of water is severe, bush dams are favored, being more pliant. The dams reduce the velocity of the water and cause deposition of soil particles, which gradually build up into flat terraces across which the water spreads and infiltrates (fig. 27).

Lower down from the watershed where the gradient flattens, these terraced fields may hold considerable amounts of water in storage and it is common in the Western Protectorate to see wells built into the stone

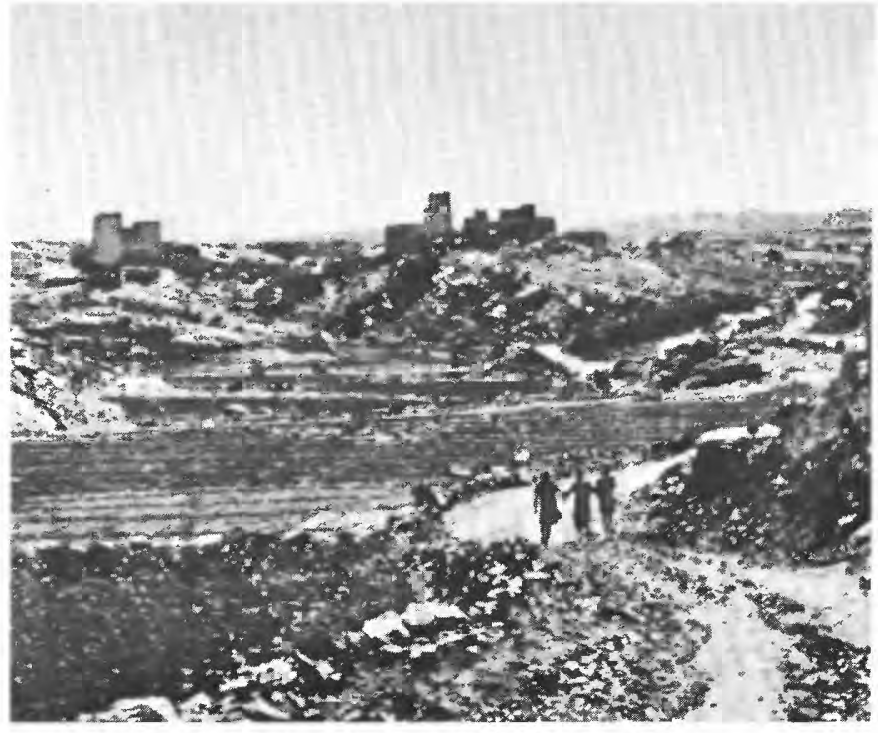

Figure 27.-Terracing with stone walls up to the watershed, Aḍ Dālít area.

terrace walls midway across the wadis, many incorporating a system for that particular field, or irrigation canals which are bucket fed by camel-operated lifting devices.

In main wadis where the force of floodwater is extremely strong, it cannot be stopped abruptly; here it is brought under control by diversions or deflectors. Stone dikes are built out on the contour into the wadis but not completely across them. A gap of several yards is left on one side in which a broad sloping stone spillway is constructed. The next dam downstream has its spillway on the opposite side, the effect of which is to divert the floodwater into a zigzag course which slows it down, enhancing percolation and reducing erosion.

Many of the larger wadis are dissected by stony watercourses from which only part of the floodwater can be utilized. Short stone or bush dams (replaced yearly) are built out from one or both sides into the watercourses to deflect water obliquely into artificial channels along which it is led, through regulators, to terraced fields downstream on the wadi flanks at a slightly lower level than the point of water intake (fig. 28). The height of the interceptor dams is determined by the maximum amount of water that the channels will take, and the surplus floodwater flows over the top. Water is conducted for great distances along these channels, which are built narrow and deep to reduce evaporation.

Isolated fields or interconnected groups of fields are also found on flood plains and on shallow pediments at the foot of high ground. In these places low walls 


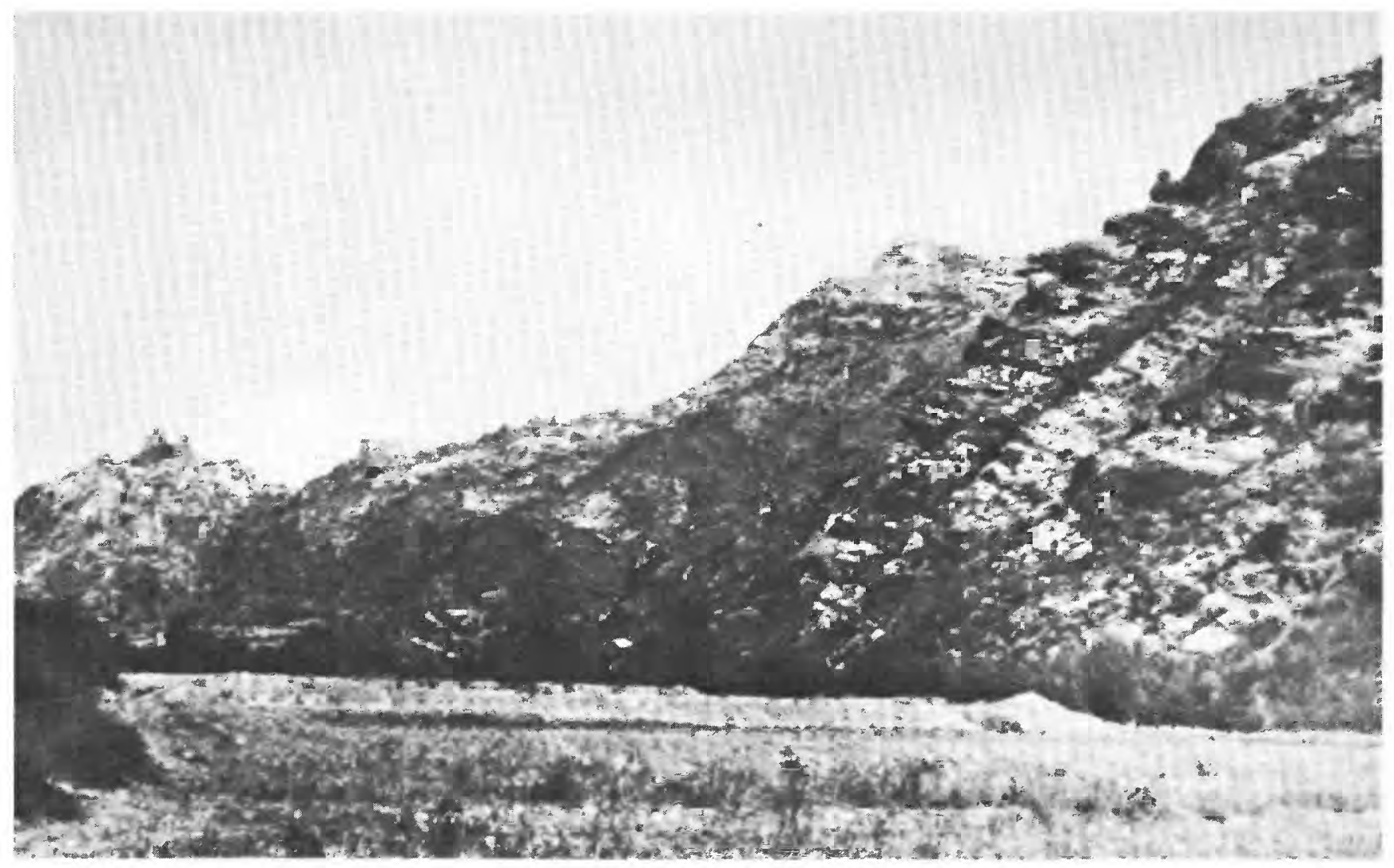

Figure 28.-Walled fields flanking large wadi, Aḍ Ḑāli' area.

of boulders are built obliquely up the pediments to a point on the debris slope above where the gradient is considerable (in several localities in the Western Protectorate slopes of $20^{\circ}$ were measured). These serve to collect and channel surface runoff onto the artificial or natural fields. To supply enough water for a season's crop growth, large collecting grounds are clearly necessary; Goldschmidt (1961) gave an average ratio of $20: 1$ for catchment area to irrigated land.

It is only in wadis and flood plains with more than about 10 feet of alluvium that permanent or semipermanent supplies of reasonably fresh water are to be expected, since they provide the only aquifers with possibilities of regular recharge. In the summer months when most wadis are completely dry, supplies of underground water may be found in sand bodies which are generally lenticular-isolated or interconnected-through which there may be slow downstream seepage. Such supplies are located by means of trial borings, the experience and intuition of the local people providing an important subjective factor. Where water regularly occurs near the surface, settlements have been established, linked by camel tracks. Dry wadis thus become important travel routes.

\section{SUGGESTED METHODS FOR LOCATION AND STORAGE OF WATER SUPPLIES}

In the larger wadis particularly, geophysical (resistivity) methods could successfully be applied to locate water, and small portable instruments are now available which are suitable for this purpose. Other limited supplies of water for domestic purposes and also possibly for irrigation might be obtained as required by sinking additional wells in the wadis, subject to the factors of low reserves of extractable water, mutual interference with neighboring wells, and the fact that the quality of ground water may vary considerably over short distances. Adjacent wells, in fact, often show great differences in total salinity (see "Well data" section) owing to variable wadi sediments through which the underground flow passes, and to differential rates of evaporation and concentration. Where the pattern of variability is on a large scale, geophysical (resistivity) methods could in many places be applied to define the bodies and channels of better quality water.

An obvious method of trapping and storing this subsurface water would be by means of dams based on the wadi floors. In practice difficulty arises in finding sites where the wadi floor and sides are suffici- 
ently impermeable and in providing low-cost material and methods of construction in isolated areas. It would appear that there is scope for research in the matter, since this type of reservoir, being underground, would substantially reduce the loss by evaporation, which under the prevailing climatic conditions may reach, if not exceed, 50 inches a year. Another very important factor is that the increase in salinity, which results from a high rate of evaporation, is reduced. Such subsurface cutoff dams can be formed by grouting with cement or bentonite directly into the ground, or by excavating and constructing, with shuttering, a wall of cement-stabilized sandy gravel or bitumenstabilized sand. According to the Soil Mechanics Division of the United Kingdom Tropical Building Research Station the local soils and wadi sediments would probably be suitable, and it was felt that slight losses by seepage through the wadi sides and floor could be accepted. With both these methods, however, special equipment is required and a further difficulty arises in the Protectorate in that wood for shuttering is not locally grown.

In addition to geophysical work, a study of the vegetation as seen on aerial photographs may be of great assistance in locating water and estimating its quality. Such interpretation is based on the simple premises that deep-rooting phreatophytes are in contact with a permanent supply of ground water of reasonable quality within 50-60 feet of the surface, and that the size of the vegetated area is a measure of the amount of water available. Mann (1957) gave a figure of 1 million gallons per annum as the water requirement for a 1-acre patch of phreatophytes (in his paper, the mesquite bush (Prosopsis)). Lines of tamarisk trees and camel-thorn shrubs are common in the wadis of the Protectorate and mark the course of surface or underground water channels; they could be used as direct indicators for locating subsurface supplies of water (fig. 29). In north-central Arabia the running gourd vine, Citrullus colocynthis (L) Schrad, is used by the local people as an indicator of ground water and with its aid they have been said to locate wells more than 200 feet deep (J. H. Whitney, in Dixey and Shaw, 1961). Patches of shallow-rooted xerophtes grow in silty flats in areas of pure desert, for example the Ramlat as Sab'atayn; these must subsist on near-surface moisture that probably is unconnected with the ground-water table and probably is derived from condensed atmospheric moisture. Remarkably heavy dews were noted even in this area and their effects on plant and animal life are clearly significant, if largely unknown. In such areas, the infrequent heavy rain which falls in storms appears to have a very long lasting effect on the vegetation, and is said by the Bedouin to be noticeable for a period of years. The land surface dries out quickly after such rains and the portion of the rainfall that has penetrated the ground deeply is sealed in by the dry surface layer.

It would appear that water can only pass through this layer in the vapor phase by a process of gaseous diffusion, which is extremely slow. Measurements taken with a thermistor in the Ramlat as Sab'atayn showed that about 3 feet below the sand surface, temperatures were remarkably constant, with no diurnal fluctuations, and were relatively low-a further factor contributing to small water losses.

In the desert areas proper, newly percolated rainwater may accumulate as lenses resting on denser saline water. During the military campaigns in the Western Libyan Desert, relatively fresh water was found overlying water having a salinity of about $5,000-6,000 \mathrm{ppm}$, that is, unpotable (Shotton, in Dixey, 1956b). Such bodies of fresh water, with salinities varying from 900 to $2,000 \mathrm{ppm}$, are normally spasmodic in occurrence, only a few feet in depth, and limited in extent. When pumped, increasing salinity points to the impending exhaustion of the supply; in general, the overpumping of ground-water supplies in arid lands gives rise to increasing salinity. A few exceptions to this occur where the extracted water is replaced by newly precipitated rainfall from local or possibly distant sources. Fresh-water bodies are known from other territories, for example the Kalahari Desert, where the underground water does not seem to be replenished, and their presence has been attributed to the fact that the water is "fossil," that it accumulated in a past humid climatic period. An alternative possibility is that the water is perched; this occurs where strata such as impermeable clay beds hold water above and separate from the main water table.

\section{WELL DATA}

Along the coast between Al Mukallā and Aden a number of fishing villages are supplied by wells within half a mile of the shore. The water levels are a few feet above mean sea level and probably represent wedges of fresh water floating on sea water (GhybenHerzberg principle). The fresh water has probably originated partly from the higher ground behind the coastal plain by slow seaward movement, and partly from natural precipitation. Typical salinities measured were as follows:

\begin{tabular}{|c|c|}
\hline & $\begin{array}{c}\text { Total } \\
\text { dissolved } \\
\text { solids } \\
(\text { ppm) }\end{array}$ \\
\hline 'Irqah. & 1,300 \\
\hline Bi'r & $-1,600$ \\
\hline Ḩișn Bal & $-1,800$ \\
\hline
\end{tabular}




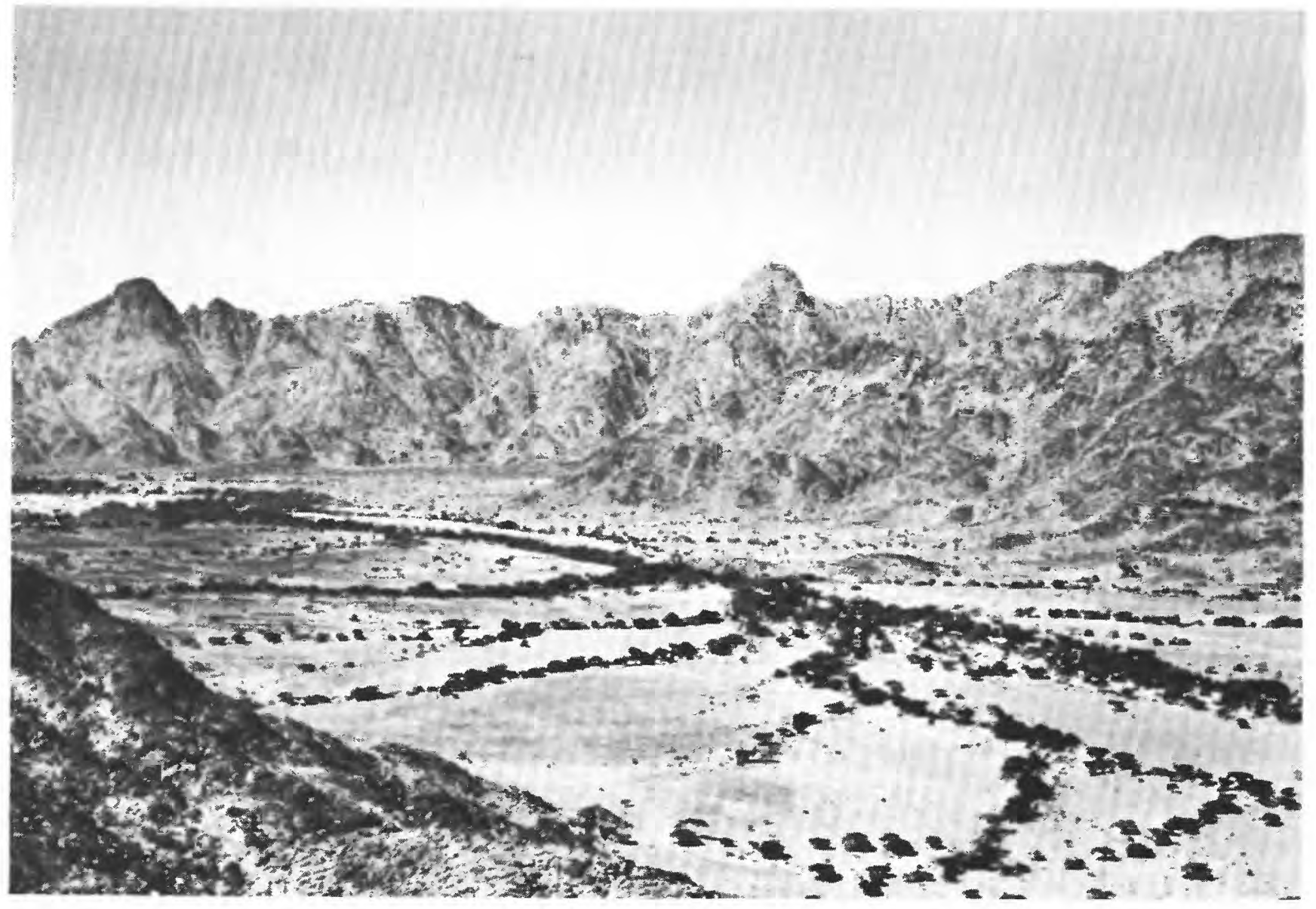

Figure 29.-Vegetation outlining the drainage pattern, Nişãb area.

Water of least salinity is found in wells in wadi beds; for example, water in Wādī Merwall contains $800 \mathrm{ppm}$. Many wadis fade out in the sand dunes with a mile or so of the sea, but a flow of water continues in underground channels, the courses of which can be plotted on aerial photographs by the rough alinement of trees and shrubs.

The quality of available water is often a critical factor, major characteristics that define quality being the total concentration of soluble salts, the percentage of bicarbonates, particularly sodium, and the presence of minor elements, such as boron, which may have toxic effects. Water containing $3,000 \mathrm{ppm}$ total dissolved solids can be used regularly for domestic purposes; even $5,000 \mathrm{ppm}$ is acceptable for short periods. Cattle can thrive on much more saline supplies, to a maximum of about $9,500 \mathrm{ppm}$. Very high concentrations of $15,600 \mathrm{ppm}$ are reportly used for sheep in Australia (Dixey, 1956b).

For irrigation the safe upper limit is considered to be about $700 \mathrm{ppm}$, although higher concentrations of certain salts could be accepted for particular crops. The suitability may thus depend as much on the proportions of the constituent ions as on their total concentration; a limiting factor is the presence of alkaline carbonates or bicarbonates, which give rise to an unfavorable soil condition (the so-called black alkali soil). At least partial chemical analyses to determine the $\mathrm{Cl}, \mathrm{SO}_{4}$, and $\mathrm{HCO}_{3}$ anions should be made to show the main characteristics of the ground water, and, particularly when the water is used continuously for irrigation, such analyses should be done as a routine practice to detect any progressive changes in chemical composition. Because the proportion of solutes increases in the soil by evaporation and may cause precipitation within the solum, efficient drainage must be combined with irrigation schemes or saline soils will result, with unfavorable crop response.

In general, ground water in the Western Protectorate was not found to be excessively saline. Domestic water from shallow. wells 30-60 feet deep was normally in the range $900 \mathrm{ppm}$ (Lawdar) to $400 \mathrm{ppm}$ (ad Dāli'; $\mathrm{Al}$ Fajarah). Wells in the larger wadis often showed surprisingly low salinities. On theoretical grounds the 
mineralization of water would be expected to increase with distance from its source by the passage through progressively larger volumes of alluvium and by concentration through evaporation. In Wādī Bayḩān, however, at the town of Bayhān a salinity of only 230 ppm was recorded; other figures were $550 \mathrm{ppm}$ at Salid and $900 \mathrm{ppm}$ at Mayfa'ah. The quality of the water, particularly in the major wadis, is often variable, however, owing to the fact that several bodies or channels of water exist. Two wells in Wādī Durā, which is almost 3 miles wide west of the town of Nişāb, gave readings of $800 \mathrm{ppm}$ (old fort) and 1,700 ppm (political officer's house); the wells were about 400 yards apart. A sample from the latter well was titrated with silver nitrate and gave a figure of $550 \mathrm{ppm}$ sodium chloride equivalent. It may be noted here that in the Abyan delta salinities also vary widely within short distances.

Some 24 miles west of Nișāb, water from an 18-foot well in the fort at Khawrah had a salinity of only 500 ppm. Between the watershed east of Khawrah and Nişāb is a large area (covering 25-35 sq mi) of apparently good agricultural land that could be very satisfactorily irrigated with water of this quality. Similarly, it was clear from the aerial photographs that Wādi Markhah, which runs parallel with Wādi Durā some 15 miles to the north, forms a very much larger area of comparable geologic background and, consequently, similar parent soil material; it also has a much greater volume of ground water owing to its greater length and catchment area. Wādĩ Markhah was closed for security reasons and was not visited by the authors.

At 'Ataq, on the edge of the sand desert, three wadis converge and the depth of alluvium is about 100 feet. The yield of water is generally low and has fallen over the last few years, but its quality is good, ranging from 650 to $850 \mathrm{ppm}$ in the four wells at 'Ataq and nearby. A certain amount of drilling was done here by Service units to locate wells for supplying the military base, but although sited in the wadis or close to them, these boreholes failed to locate fresh supplies. As there are no surface geologic features to indicate where the underground water channels may lie, resort must be had to geophysical methods, and it has already been shown that resistivity can be used successfully under similar conditions in Wãdi Haḍramawt (S. H. Shaw, unpub. data, 1952). Twenty-five miles north of ' $\mathrm{Iy} \overline{\mathrm{a}} \mathrm{dh}$, on the southern fringe of the Ramlat as Sab'atayn, the ground water was found to be of even higher quality, namely $100 \mathrm{ppm}$. Highly mineralized water might have been expected instead, because the 'Iyādh well lies in Wādi Jirdān which draws its water from the limestone jol to the east, where gypseous beds are numerous.

\section{PROSPECTS}

Presumably, possibilities exist for finding water in the area of desert to the west, in the Jaww Kudayf and the Ramlat as Sab'atayn, because many wadi courses extend for several miles into them from the NişắbBayhān mountains on the south and the limestone jol in the east. The most outstanding example observed is Wādi Bayhān, which can be traced at least 45 miles into the desert, as far as Al 'Ubaylāt. It is well marked on the ground, although the wadi floor is not level and is obstructed at many points by sand dunes. No record of data of the last flood to reach $\mathrm{Al}$ 'Ubaylāt could be obtained, but to the west of the present wadi, broken lines of trees now partly submerged in sand indicated that the course of the wadi had moved progressively to the east with the prevailing wind. Separating the hill known as Faridah from the southern end of the main ridge of Jabal ath Thaniyah is a wide, shallow wadi containing gravel banks and small boulders of quartzite. This is reputed to be Wādī al Abrād which, according to Philby (1938), rises in the Yemen mountains more than 50 miles to the west, the ancient city of Ma'rib being on one of its tributaries.

Flood water which percolates below the level of ground affected by evaporation would presumably remain available, although at considerable depths, probably in excess of 150 feet. Well-defined permanent wadis would be expected to carry a slow underground flow past the point where they cease to be recognizable as wadis at the surface. This water may even add to a permanent ground-water table at depth beneath the desert, although if such exists it is probably saline as a result of concentration by slow upward diffusion of water vapor. If geophysical work is undertaken in the 'Ataq area, the hydrologic conditions at the mouths of the larger nearby wadis should be investigated. Here outwash fans of various types are common, parts of which consist of silt or silty sand. These could be walled and used for agriculture if water were available.

\section{GAZETTEER}

Degrees of latitude and longitude are given to the nearest minute. The coordinates given for wadis indicate the general location of the principal references in the text.

\begin{tabular}{|c|c|c|}
\hline & $\begin{array}{c}\text { Latitude } \\
(N .)\end{array}$ & $\begin{array}{c}\text { Longitude } \\
(E .)\end{array}$ \\
\hline Abyan delta_ & $13^{\circ} 07^{\prime}$ & $45^{\circ} 22^{\prime}$ \\
\hline Ad Dali“... & $13^{\circ} 42^{\prime}$ & $44^{\circ} 44^{\prime}$ \\
\hline Aden $\ldots . .$. & $12^{\circ} 46^{\prime}$ & $45^{\circ} 02^{\prime}$ \\
\hline Abswar......... & $13^{\circ} 32^{\prime}$ & $46^{\circ} 43^{\prime}$ \\
\hline Al Anad. . . . . . . . & $13^{\circ} 16^{\prime}$ & $44^{\circ} 45^{\prime}$ \\
\hline Al Fajarah & $12^{\circ} 59^{\prime}$ & $44^{\circ} 19^{\prime}$ \\
\hline Al Hujayrah & $14^{\circ} 25^{\prime}$ & $46^{\circ} 28^{\prime}$ \\
\hline Al Hुuşāann $\ldots$ & $14^{\circ} 42^{\prime}$ & $46^{\circ} 30^{\prime}$ \\
\hline Al Khabr. & $14^{\circ} 06^{\prime}$ & $47^{\circ} 05^{\prime}$ \\
\hline
\end{tabular}


Al Kirsh

Al Mājil.

Al Maḩfid

Al Mukalla

Al Musaymir

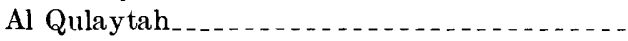

Al 'Ubaylāt.

'Alì 'Abd Allāh. . . . . . . . . . . . . . . . . . .

An Naşr

An Nuqūb

'Arf ad Dïk (jebel)

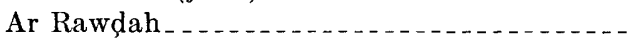

As Sawād.

Ash Shatt

As Sufāl

Aş Șurrah

'Ataq-_._.

'Awābil

Balbuāf.

Bayb̧ān (Bayb̧ān al Qaşab) ............

Bi'r 'Ali.

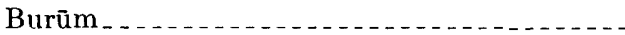

Dār Rahbān

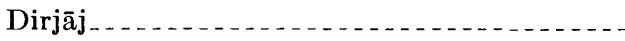

Ghayl Barbar .

Habbān . . . .

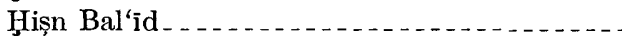

Ḩişn Murād

'Irqah. . . . .

'Iyādh . . . . . . . . . . . . . . . . . . . . .

Jabal ad Da'liyah. . . . . .

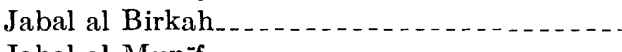

Jabal al Munif . . . . . . . . . . . . . . . . .

Jabal ath Thaniyah.

Jabal Jahmum . . . .

Jabal Jihäf

Jabal Kharaz

Jabal Kuwah

Jabal Marsá _. . . .

Jabal Sunamma . .

Jabal Suwayqah

Jabal Zulm Ash Shaybah. ...............

Jawl Aş Şalab

Ji'ār... . . . . . . . . . . . . . . . . . . . .

Jibāl al Aswad.

Jibāl an Nisìyin

Jilla (Jil'ah)

Jizwil.....

Karīf Shawrān

Kawr al 'Awādhil (area)

Khanfar.

Khawrah ..............

Labj -

Lawdar.........

Ma'bar

Marta'ah

Mayfa'ah.

Minādī.

Mūdiyah.

Mukayrās

Muşayni'ah

\begin{tabular}{|c|c|}
\hline $\begin{array}{l}\text { Latitude } \\
(N .)\end{array}$ & $\underset{(E .)}{L \text { Longitude }}$ \\
\hline $13^{\circ} 22^{\prime}$ & $44^{\circ} 30^{\prime}$ \\
\hline $13^{\circ} 50^{\prime}$ & $45^{\circ} 47^{\prime}$ \\
\hline $14^{\circ} 02^{\prime}$ & $46^{\circ} 55^{\prime}$ \\
\hline $13^{\circ} 20^{\prime}$ & $45^{\circ} 18^{\prime}$ \\
\hline $14^{\circ} 32^{\prime}$ & $49^{\circ} 07^{\prime}$ \\
\hline $13^{\circ} 26^{\prime}$ & $44^{\circ} 37^{\prime}$ \\
\hline $13^{\circ} 58^{\prime}$ & $46^{\circ} 43^{\prime}$ \\
\hline $15^{\circ} 09^{\prime}$ & $46^{\circ} 23^{\prime}$ \\
\hline $12^{\circ} 46^{\prime}$ & $44^{\circ} 02^{\prime}$ \\
\hline $15^{\circ} 29^{\prime}$ & $47^{\circ} 00^{\prime}$ \\
\hline $14^{\circ} 58^{\prime}$ & $45^{\circ} 48^{\prime}$ \\
\hline $15^{\circ} 36^{\prime}$ & $46^{\circ} 44^{\prime}$ \\
\hline $14^{\circ} 22^{\prime}$ & $48^{\circ} 31^{\prime}$ \\
\hline $13^{\circ} 29^{\prime}$ & $45^{\circ} 36^{\prime}$ \\
\hline $13^{\circ} 29^{\prime}$ & $45^{\circ} 34^{\prime}$ \\
\hline $12^{\circ} 54^{\prime}$ & $44^{\circ} 01^{\prime}$ \\
\hline $14^{\circ} 18^{\prime}$ & $47^{\circ} 02^{\prime}$ \\
\hline $13^{\circ} 57^{\prime}$ & $46^{\circ} 14^{\prime}$ \\
\hline $14^{\circ} 31^{\prime}$ & $46^{\circ} 46^{\prime}$ \\
\hline $13^{\circ} 50^{\prime}$ & $44^{\circ} 52^{\prime}$ \\
\hline $13^{\circ} 58^{\prime}$ & $48^{\circ} 10^{\prime}$ \\
\hline $14^{\circ} 49^{\prime}$ & $45^{\circ} 44^{\prime}$ \\
\hline $14^{\circ} 01^{\prime}$ & $48^{\circ} 21^{\prime}$ \\
\hline $14^{\circ} 21^{\prime}$ & $48^{\circ} 57^{\prime}$ \\
\hline $12^{\circ} 52^{\prime}$ & $44^{\circ} 03^{\prime}$ \\
\hline $13^{\circ} 16^{\prime}$ & $45^{\circ} 21^{\prime}$ \\
\hline $12^{\circ} 50^{\prime}$ & $43^{\circ} 57^{\prime}$ \\
\hline $14^{\circ} 19^{\prime}$ & $47^{\circ} 07^{\prime}$ \\
\hline $13^{\circ} 33^{\prime}$ & $46^{\circ} 58^{\prime}$ \\
\hline $12^{\circ} 40^{\prime}$ & $43^{\circ} 30^{\prime}$ \\
\hline $13^{\circ} 38^{\prime}$ & $47^{\circ} 20^{\prime}$ \\
\hline $14^{\circ} 58^{\prime}$ & $46^{\circ} 48^{\prime}$ \\
\hline $14^{\circ} 26^{\prime}$ & $48^{\circ} 36^{\prime}$ \\
\hline $12^{\circ} 42^{\prime}$ & $44^{\circ} 22^{\prime}$ \\
\hline $13^{\circ} 17^{\prime}$ & $44^{\circ} 51^{\prime}$ \\
\hline $15^{\circ} 48^{\prime}$ & $46^{\circ} 19^{\prime}$ \\
\hline $14^{\circ} 12^{\prime}$ & $48^{\circ} 35^{\prime}$ \\
\hline $13^{\circ} 45^{\prime}$ & $44^{\circ} 41^{\prime}$ \\
\hline $12^{\circ} 44^{\prime}$ & $44^{\circ} 10^{\prime}$ \\
\hline $12^{\circ} 42^{\prime}$ & $43^{\circ} 30^{\prime}$ \\
\hline $12^{\circ} 40^{\prime}$ & $44^{\circ} 25^{\prime}$ \\
\hline $12^{\circ} 42^{\prime}$ & $44^{\circ} 20^{\prime}$ \\
\hline $14^{\circ} 09^{\prime}$ & $48^{\circ} 14^{\prime}$ \\
\hline $14^{\circ} 10^{\prime}$ & $48^{\circ} 50^{\prime}$ \\
\hline $14^{\circ} 23^{\prime}$ & $46^{\circ} 40^{\prime}$ \\
\hline $13^{\circ} 13^{\prime}$ & $45^{\circ} 19^{\prime}$ \\
\hline $14^{\circ} 26^{\prime}$ & $47^{\circ} 44^{\prime}$ \\
\hline $14^{\circ} 48^{\prime}$ & $46^{\circ} 08^{\prime}$ \\
\hline $14^{\circ} 00^{\prime}$ & $48^{\circ} 07^{\prime}$ \\
\hline $14^{\circ} 23^{\prime}$ & $48^{\circ} 22^{\prime}$ \\
\hline $14^{\circ} 01^{\prime}$ & $48^{\circ} 22^{\prime}$ \\
\hline $13^{\circ} 58^{\prime}$ & $45^{\circ} 52^{\prime}$ \\
\hline $13^{\circ} 13^{\prime}$ & $45^{\circ} 19^{\prime}$ \\
\hline $14^{\circ} 27^{\prime}$ & $46^{\circ} 08^{\prime}$ \\
\hline $13^{\circ} 03^{\prime}$ & $44^{\circ} 53^{\prime}$ \\
\hline $13^{\circ} 53^{\prime}$ & $45^{\circ} 53^{\prime}$ \\
\hline $14^{\circ} 15^{\prime}$ & $48^{\circ} 33^{\prime}$ \\
\hline $14^{\circ} 08^{\prime}$ & $45^{\circ} 55^{\prime}$ \\
\hline $14^{\circ} 14^{\prime}$ & $47^{\circ} 32^{\prime}$ \\
\hline $13^{\circ} 48^{\prime}$ & $44^{\circ} 45^{\prime}$ \\
\hline $13^{\circ} 54^{\prime}$ & $46^{\circ} 03^{\prime}$ \\
\hline $13^{\circ} 56^{\prime}$ & $45^{\circ} 41^{\prime}$ \\
\hline $15^{\circ} 04^{\prime}$ & $50^{\circ} 38$ \\
\hline
\end{tabular}

Nișāb (Anşāb)

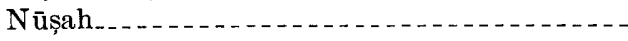

Ra's ar Rujaymah.

Ra's Fartak ................................

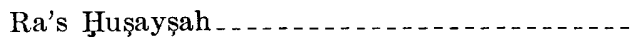

Ra's 'Imrān.

Ra's Majdahah.

Ra's Muwaysah

Ra's Sharwayn

Ra's Quşay'ir

Rudhūm

Şāfir

Şa'ìd.

Sanāh.-

Shabwah

Sharkhāt

Shuqrah

Sidārah (Sidara)

Thawr al Bahā

Thirah

Wādì 'Abadān

Wādi A hwar _.

Wādì al Ghabar.

Wādī al Jahr.--

Wādì al Jif'iyah

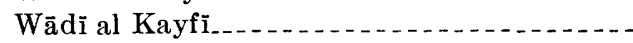

Wādì Ba'Aryab.

Wādì Banā.

Wādi Dār

âdi Dayqah.

Wādi Durā...

Wādì Gharīsh.

Wādi Huabbān.

Wādī Ḩajr.

Wäi Hasan

Wādi Hुimam . . . .

Wādi Jadin ...

Wādi Jirdān . . . .

Wādi Markhah.

Wādi Mațärif .

Wādì Mayfa'ah.

Wādi Milh.

Wādì Raybān.

Wādi Raymah. .......

Yashbum

Zinjibār _............

Zulm Bā Tha'lab.

\section{BIBLIOGRAPHY}

Bagnold, R. A., 1938, The physics of blown sand and desert dunes: New York, Morrow \& Co.

Beydoun, Z. R., 1960, Synopsis of the geology of East Aden Protectorate: Internat. Geol. Cong., 21st, Copenhagen 1960, Rept., pt. 21, p. 131-149.

- 1961, The stratigraphy and structure of the East Aden Protectorate: Oxford Univ. Ph. D. thesis.

- 1964, The stratigraphy and structure of the Eastern Aden Protectorate: London, Overseas Geology and Mineral Resources Bull. Supp. ser. 5, 107 p.

Blanford, W. T., 1869, On the geology of a portion of Abyssinia: Geol. Soc. Lond on Quart. Jour., v. 25, p. 401-406.

Brown, G. F., 1960, Geomorphology of western and central Saudi Arabia: Internat. Geol. Cong., 21 st, Copenhagen 1960, Rept., pt. 21 , p. $150-159$.

\begin{tabular}{|c|c|}
\hline $\begin{array}{c}\text { Latitude } \\
(N .)\end{array}$ & $\begin{array}{c}\text { Longitude } \\
(E .)\end{array}$ \\
\hline $14^{\circ} 31^{\prime}$ & $46^{\circ} 29^{\prime}$ \\
\hline $14^{\circ} 00^{\prime}$ & $46^{\circ} 43^{\prime}$ \\
\hline $48^{\circ} 07^{\prime}$ & $48^{\circ} 45^{\prime}$ \\
\hline $15^{\circ} 38^{\prime}$ & $52^{\circ} 14^{\prime}$ \\
\hline $14^{\circ} 12^{\prime}$ & $48^{\circ} 50^{\prime}$ \\
\hline $12^{\circ} 44^{\prime}$ & $44^{\circ} 44^{\prime}$ \\
\hline $13^{\circ} 59^{\prime}$ & $48^{\circ} 28^{\prime}$ \\
\hline $14^{\circ} 09^{\prime}$ & $48^{\circ} 48^{\prime}$ \\
\hline $15^{\circ} 20^{\prime}$ & $51^{\circ} 40^{\prime}$ \\
\hline $14^{\circ} 55^{\prime}$ & $50^{\circ} 20^{\prime}$ \\
\hline $14^{\circ} 04^{\prime}$ & $47^{\circ} 40^{\prime}$ \\
\hline $15^{\circ} 40^{\prime}$ & $46^{\circ} 07^{\prime}$ \\
\hline $14^{\circ} 20^{\prime}$ & $46^{\circ} 52^{\prime}$ \\
\hline $13^{\circ} 49^{\prime}$ & $44^{\circ} 43^{\prime}$ \\
\hline $15^{\circ} 22^{\prime}$ & $47^{\circ} 01^{\prime}$ \\
\hline $15^{\circ} 09^{\prime}$ & $51^{\circ} 02^{\prime}$ \\
\hline $13^{\circ} 21^{\prime}$ & $45^{\circ} 42^{\prime}$ \\
\hline $14^{\circ} 30^{\prime}$ & $48^{\circ} 05^{\prime}$ \\
\hline $13^{\circ} 11^{\prime}$ & $44^{\circ} 18^{\prime}$ \\
\hline $13^{\circ} 55^{\prime}$ & $45^{\circ} 48^{\prime}$ \\
\hline $14^{\circ} 30^{\prime}$ & $46^{\circ} 28^{\prime}$ \\
\hline $13^{\circ} 39^{\prime}$ & $46^{\circ} 38^{\prime}$ \\
\hline $14^{\circ} 13^{\prime}$ & $48^{\circ} 48^{\prime}$ \\
\hline $13^{\circ} 58^{\prime}$ & $46^{\circ} 32^{\prime}$ \\
\hline $15^{\circ} 00^{\prime}$ & $45^{\circ} 57^{\prime}$ \\
\hline $13^{\circ} 17^{\prime}$ & $44^{\circ} 35^{\prime}$ \\
\hline $14^{\circ} 09^{\prime}$ & $48^{\circ} 48^{\prime}$ \\
\hline $13^{\circ} 23^{\prime}$ & $45^{\circ} 16^{\prime}$ \\
\hline $13^{\circ} 16^{\prime}$ & $44^{\circ} 32^{\prime}$ \\
\hline $13^{\circ} 47^{\prime}$ & $46^{\circ} 39^{\prime}$ \\
\hline $14^{\circ} 26^{\prime}$ & $46^{\circ} 22^{\prime}$ \\
\hline $14^{\circ} 08^{\prime}$ & $48^{\circ} 11^{\prime}$ \\
\hline $14^{\circ} 18^{\prime}$ & $47^{\circ} 02^{\prime}$ \\
\hline $14^{\circ} 14^{\prime}$ & $48^{\circ} 33^{\prime}$ \\
\hline $13^{\circ} 24^{\prime}$ & $45^{\circ} 27^{\prime}$ \\
\hline $14^{\circ} 40^{\prime}$ & $49^{\circ} 08^{\prime}$ \\
\hline $12^{\circ} 49^{\prime}$ & $44^{\circ} 11^{\prime}$ \\
\hline $14^{\circ} 58^{\prime}$ & $46^{\circ} 48^{\prime}$ \\
\hline $14^{\circ} 38^{\prime}$ & $46^{\circ} 14^{\prime}$ \\
\hline $14^{\circ} 56^{\prime}$ & $46^{\circ} 24^{\prime}$ \\
\hline $14^{\circ} 08^{\prime}$ & $47^{\circ} 36^{\prime}$ \\
\hline $13^{\circ} 47^{\prime}$ & $45^{\circ} 43^{\prime}$ \\
\hline $13^{\circ} 37^{\prime}$ & $45^{\circ} 39^{\prime}$ \\
\hline $14^{\circ} 11^{\prime}$ & $48^{\circ} 37^{\prime}$ \\
\hline $14^{\circ} 17^{\prime}$ & $46^{\circ} 56^{\prime}$ \\
\hline $13^{\circ} 07^{\prime}$ & $45^{\circ} 23^{\prime}$ \\
\hline $14^{\circ} 17^{\prime}$ & $48^{\circ} 23$ \\
\hline
\end{tabular}


Brown, G. F., and Jackson, R. O., 1960, The Arabian shield: Internat. Geol. Cong., 21st, Copenhagen 1960, Rept. 21, pt. 9, p. $69-77$.

Bunker, D. G., 1953, The southwest borderlands of the Rub'al Khali: Geog. Jour., v. 119, pt. 4, p. 420-430.

Carey, W. S., 1958, The tectonic approach to continental drift, in Continental Drift Symposium: Hobart, Tasmania Univ., p. $177-198$.

Carte géologique internationale de l'Afrique, 1960: Internat. Geol. Cong., Paris, Assoc. Service Géology Africains.

Cloos, H., 1939, Hebung, Spaltung, und Vulkanismus: Geol. Rundschau, v. 30 , no. 4 A, p. $405-527$.

Cox, L. R., 1931, The geology of the Farsan Islands, Gizan and Kamaran Island, Red Sea. Part II. Molluscan paleontology: Geol. Mag., v. 68, p. 1-13.

Dixey, Frank, 1956a, The east African rift system: Colonial Geology and Mineral Resources Bull. Supp. 1.

- 1956b, Variability and predictability of water supply, in The future of arid lands [papers and recommendations from the international arid lands meeting, edited by G. C. White]: Am. Assoc. Adv. Sci., Pub. 43, p. 121-140.

Dixey, F., and Shaw, S. H., 1961, Hydrology with reference to salinity, introduction to Section 1 of Salinity problems in the arid zones: UNESCO, Teheran Symposium, 1958, Proc., Arid Zone Research 14, p. 15-18.

Eskola, P., 1933, On the differential anatexis of rocks: Finlande Comm. Géol. Bull. 103, p. 12-25.

Gellatly, D. C., 1960, Report on the geology of the Las Dureh area, Burao District: Somali Republic Geol. Survey Rept. 6, $40 \mathrm{p}$.

Geukens, Fernand, 1960, Contribution à la géologie du Yemen: Louvain Univ., Inst. Géol. Mém., v. 21, p. 117-180.

Girdler, R. W., 1958, The relationship of the Red Sea to the east African rift system: Geol. Soc. Lond on Quart. Jour., v. 114, pt. 1 , p. $79-105$.

Goldschmidt, M. J., 1961, On the mechanism of the replenishment of aquifers in the Negev [the arid region of Israel]: Internat. Assoc. Sci. Hydrology, Internat. Union Geodesy and Geophysics, Athens Symposium, v. 2, p. 547-550.

Greenwood, J. E. G. W., 1960, Report on the geology of the Las Khoreh-Elayu area, Erigavo district: Somaliland, Geol. Survey Rept. no. 3, 36 p.

- 1961, The Inda Ad Series of the former Somaliland Protectorate: London, Overseas Geology and Mineral Resources Bull., v. 8, no. 3, p. 288-296.

Gregory, J. W., 1921, The rift valleys and geology of east Africa: London, Seeley, Service and Co., Ltd., 479 p.

Hawkes, H. E., 1957, Principles of geochemical prospecting: U.S. Geol. Survey Bull. 1000-F, p. 225-355.

Hobbs, W. H., 1911, Repeating patterns in the relief and in the structure of the land: Geol. Soc. America Bull., v. 22, p. $123-176$.

Hudson, R. G. S., 1954, Jurassic stromatoporoids from southern Arabia: Paris, Mus. natl. d'Histoire naturelle, Notes et Mém. sur le Moyen-Orient, v. 5, p. 207-221.

Hunt, J. A., 1958, Report on the geology of the Adadleh area, Hargeisa and Berbera districts: Somaliland, Geol. Survey Rept. no. 2, $16 \mathrm{p}$.

1960, Report on the geology of the Berbera-Sheikh area, Berbera and Burao districts: Somaliland, Geol. Survey Rept. no. 4, 27 p.

Irving, E., and Tarling, D. H., 1961, The paleomagnetism of the Aden Volcanics: Jour. Geophys. Research, v. 66, no. 2, p. $549-556$.
Jaques, E. H., 1954, Geology of the Aden Protectorate: Port of Aden Annual, 1953-54, p. 46-48.

Karpoff, Roman, 1957, Esquisse géologique de l'Arabie séoudite: Soc. Géol. France Bull., v. 7, ser. 6, p. 653-697.

Karpoff, R., 1960, L'Antecambrian de la Peninsule Arabique: Internat. Geol. Cong., 21st, Copenhagen 1960, Rept. 21, pt. 9 , p. $78-94$.

Karrenberg, H., 1956, Young magmatism and volcanism in southwest Arabia (Yemen): Internat. Geol. Cong., 20th, Mexico 1956, Rept., sec. 1, p. 10.

- 1959, Junger magmatismus in Sudwest-Arabien (Yemen): Technische Mitteilungen Krupp, v. 17, p. 33-36.

Krenkel, E., 1925, Geologie Afrikas: Berlin, Gebrüder Bomtraeger, pt. 1, 462 p.

Lamare, Pierre, 1930, Les manifestations volcaniques postcrétacées de la Mer Rouge et des pays limitrophes, in Teilhard de Chardin, Pierre, and others, Etudes géologiques en Ethiopie, Somalie, et Arabie meridionale: Soc. Geol. France Mém., new ser., no. 14, p. 21-48. - 1936, Structure géologique de l'Arabie: Paris and Liége, Libraire Polytechnique Ch. Béranger, 63 p.

Little, O. H., 1925, The geography and geology of Makalla (South Arabia): Cairo, Egypt Geol. Survey Pub., Government Press, 250 p.

Lloyd, R. E., 1910, The geology of the Aden hinterland: India Geol. Survey Recs., v. 38 , pt. 4, p. 313-341.

Lovering, T. S., Huff, L. C., and Almond, H., 1950, Dispersion of copper from San Manuel copper deposit, Pinal County, Arizona: Econ. Geology, v. 45, no. 6, p. 493-514.

McMahon, C. A., 1883, On the lavas of Aden: India Geol. Survey, Recs. v. 16, p. 145-158.

Mann, J. F., 1957, Estimating quantity and quality of ground water in dry regions using airphotos: Internat. Geod. Geophys. Union, Assoc. Sci. Hydrology Gen. Assembly, Toronto 1957, v. 2, p. 125-134, Gentbrugge, Belgium [1958].

Mason, J. E., and Warden, A. J., 1956, The geology of the HeisMait-Waqderia area, Erigavo district: Somaliland, Geol. Survey Rept. no. 1, 23 p.

Moody, J. D., and Hill, M. J., 1956, Wrench-fault tectonics: Geol. Soc. America Bull., v. 67, p. 1207-1246.

Philby, H. St. J., 1938, The land of Sheba, Part 2: Geog. Jour., v. 92 , no. 2 , p. $107-132$.

Picard, L., 1937, On the structure of the Arabian Peninsula: Hebrew Univ. Jerusalem Geol. Dept. Bull., ser. 1, no. 3, p. $1-12$.

Quennell, A. M., 1951, The geology and mineral resources of (former) Trans-Jordon: Colonial Geology and Mineral Resources Bull., v. 2, no. 2, p. 85-115.

Raisin, C. A., 1902, Notes on the geology of Perim Island: Geol. Mag., v. 9, p. 206-10.

Read, H. H., 1957, The granite controversy: London, Murby, $430 \mathrm{p}$.

Said, R., 1962, The geology of Egypt: Amsterdam-New York, Elsevier Putb. Co., 377 p.

Schatsky, N. S., 1960, Principles of late Pre-Cambrian stratigraphy and the scope of the Riphean Group: Internat. Geol. Cong., 21st, Copenhagen 1960, Rept., pt. 8, p. 7-17.

Schürmann, H. M. E., 1961, The Riphean of the Red Sea area: Geol. Fören. Stockholm Förh., v. 83, no. 2, p. 109-128.

Somaliland Oil Exploration Company, Ltd., 1954, A geological reconnaissance of the sedimentary deposits of the Protectorate of British Somaliland: London, Crown Agents, 42 p. 
Sonder, R. A., 1947, Dicsussion of "Shear pattern of the earth's crust," by F. A. Vening Meinesz: Am. Geophys. Union Trans., v. 28, no. 6, p. 939-945.

Steineke, Max, Bramkamp, R. A., and Sander, N. J., 1958, Stratigraphic relations of Arabian Jurassic oil, in Habitat of Oil: Tulsa, Am. Assoc. Petroleum Geologists, p. 1294-1329.

Stocks, T., 1941, Die Tiefenverhaltnisse des Golfes von Aden: Zeitschr. Gesell. Erdkunde, pts. 5 and 6 (chart referred to is reproduced in Geol. Rundschau, v. 33, no. 4-6, p. 355, 1942).

Vening Meinesz, F. A., 1947, Shear patterns of the earth's crust: Am. Geophys. Union Trans., v. 28, no. 1, p. 1-61.

Wissmann, Hermann von, Rathjens, C., and Kossmat, F., 1942, Beiträge zur Tektonik Arabiens: Geol. Rundschau, v. 33, no. 4-6, p. 221-353. 


\section{APPENDIX}

221-671 $0-67-7$ 


\section{AGE DETERMINATION RESULTS}

By N. J. SNELling ${ }^{4}$

Recent work in Aden Protectorate and Somalia (former Somaliland Protectorate) has revealed marked similarities in the Precambrian geology of these terrains. In both regions the basement rocks have been subjected to two episodes of metamorphism, the first of which was the more intense, conditions reaching those of the amphibolite facies, and in parts of Somalia, the granulite facies. For convenience this episode is referred to as katametamorphism. The second metamorphism was generally of much lower grade, only locally reaching the conditions appropriate to the amphibolite facies, and with mainly dynamic effects much in evidence. This episode is referred to as epimetamorphism. Present in both regions are low-grade metasedimentary rocks comprising the Ghabar Group of the E.A.P. (Beydoun, 1960) and the Inda Ad Series of Somalia. The relationship of these formations to the crystalline basement rocks is obscure, although the evidence favors an unconformable relationship between the Somalia basement rocks and the Inda Ad Series.

Several phases of plutonic igneous activity can be distinguished. In both regions the katametamorphism was accompanied by the development of autochthonous and parautochthonous granites (the syntectonic granites of Greenwood in Aden Protectorate and the synkinematic granites of Warden in Somalia), and the later epimetamorphism was followed by the intrusion of posttectonic granites that have sharp crosscutting contacts and well-defined thermal aureoles. In Aden Protectorate, Greenwood has distinguished a group of granites which are later than the katametamorphism but earlier than the epimetamorphism, which he terms the intertectonic granites; in Somalia, Daniels, Skiba, and Sutton (1963) have described a group of layered gabbroic intrusions which also postdate the katametamorphism and predate the epimetamorphism. These layered mafic intrusions are of particular importance in that they indicate a longtime interval between the two metamorphisms in Somalia. Thus in some localities well-defined thermal aureoles have been observed adjacent to the gabbros, indicating that the country rocks had time to cool after the early katametamorphism, whereas

\footnotetext{
${ }^{4}$ Of the Overseas Geological Surveys.
}

the banded nature of these mafic rocks indicates the slow accumulation of crystals by gravity differentiation, which could only occur during a long period of quiescence.

\begin{tabular}{|c|c|c|c|c|}
\hline \multicolumn{5}{|c|}{$\begin{array}{l}\text { [In calculating the K-Ar ages the following constants were used: } \\
\qquad \begin{array}{c}{ }^{0} \mathrm{~K} \lambda \beta=4.72 \times 10^{-10} \mathrm{yr}^{-1} \\
\lambda e=0.584 \times 10^{-10} \mathrm{yr}^{-1}\end{array}\end{array}$} \\
\hline $\begin{array}{c}\text { Determination } \\
\text { No. }\end{array}$ & Nature and location & $\begin{array}{l}\text { Potas- } \\
\text { sium } \\
\text { (per- } \\
\text { cent) }\end{array}$ & $\begin{array}{c}{ }^{40} \mathrm{Ar} / 4^{40} \mathrm{~K} \\
\text { ratio }\end{array}$ & $\begin{array}{c}\text { Age } \\
(\mathrm{m} . \mathrm{y} .)\end{array}$ \\
\hline
\end{tabular}

\begin{tabular}{|c|c|c|c|c|}
\hline \multicolumn{5}{|c|}{ Former British Somaliland } \\
\hline OGS.62.50 & Biotite from Daimoleh granodiorite & 7.75 & 0.0331 & $495 \pm$ \\
\hline $51 \ldots$ & Muscovite from garnet-muscovite & 7.22 & .0415 & $600=$ \\
\hline 45. & $\begin{array}{l}\text { Botite from biotite-adamellite intru- } \\
\text { sive into basement rocks and the } \\
\text { Inda Ad Sries. Near Mait. Lat } \\
10^{\circ} 50^{\prime} \mathrm{N} \text {., long } 47^{\circ} 12^{\prime} \mathrm{E} \text {. Mait. }\end{array}$ & 7.57 & .0337 & $500 \pm 2$ \\
\hline 44 & $\begin{array}{l}\text { Biotite from Las Bar granite, post- } \\
\text { Inda Ad Series. }\end{array}$ & 6. 84 & .0346 & \\
\hline 42 . & $\begin{array}{l}\text { Whole rock "metamorphosed argilla- } \\
\text { ceouls sandstone" } 1 \mathrm{A9A} \text {, Inda Ad } \\
\text { Series Map sheet } 6\end{array}$ & 2.86 & .0335 & $500 \pm$ \\
\hline $45_{-}$ & $\begin{array}{l}\text { Whole rock "mudstone", } 1 \text { AS. } 47 \text {, Inda } \\
\text { Ad Series. Map sheet } 6 .\end{array}$ & 1.05 & .0243 & $380 \pm 4$ \\
\hline \multicolumn{5}{|c|}{ Aden Protectorate } \\
\hline 63.12 & \multirow{7}{*}{ 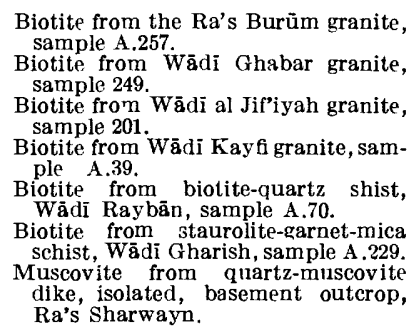 } & 7.47 & & $515 \pm$ \\
\hline $62.53 \ldots$ & & 6.55 & 0.0383 & $560 \pm$ \\
\hline 52 & & 7.73 & .0375 & $550 \pm$ \\
\hline $63.11 \ldots$ & & 6.57 & & $475 \pm 2$ \\
\hline $62.53 \ldots$ & & 7.01 & .0337 & $505 \pm$ \\
\hline 63.131 & & 6.85 & .0429 & 620 \\
\hline 61.39 & & 8.59 & .0310 & $470 \pm$ \\
\hline
\end{tabular}

1 A corrected determination gives an apparent age of $575 \pm 25 \mathrm{~m}$.y. and a ${ }^{40} \mathrm{Ar} /{ }^{40} \mathrm{~K}$ ratio of 0.0394

New age determinations on rocks from Somalia and the Aden Protectorate are given in table 8. Most of the determinations were made on samples submitted by geologists of the former Geological Survey of Somaliland Protectorate and of the Overseas Geological Surveys. Determinations were all made by the potassium-argon method which, on the basis of past experience, has proved of greatest value to reconnaissance studies of geologically little known areas. Argon was determined by the isotope-dilution method, by using a bakeable all-glass vacuum system and a Reynolds-type glass mass spectrometer. Potassium 
was determined by means of an Eel flame photometer by direct comparison with standard solutions.

Probably the most important of these new age determinations are those on the Las Bar, Ra's Burūm, and Mait granites. These are all clearly posttectonic bodies having crosscutting contacts and thermal aureoles. The similarity of the determinations strongly suggests that they date the time of intrusion. In terms of current estimates of the geological time scale these granites are of Late Cambrian age. In E.A.P. the Ra's Burūm granite intrudes older volcanic rocks (see Greenwood, 1961, pl. 1); in Somalia the Las Bar granite intrudes metasedimentary rocks of the Inda Ad Series, and the Mait granite cuts both regionally metamorphosed basement rocks and members of the Inda Ad Series. Thus in Sonalia the basement gneisses and apparently overlying Inda Ad Series are Cambrian or older, as are the two metamorphic episodes recognized in the region. Little more can be said about the actual ages of these metamorphisms, but it is reasonable to suggest that the epimetamorphism in the basement rocks and the dynamic metamorphism which has affected the Inda Ad Series are one and the same event. Attempts to date this event by making wholerock potassium-argon determinations on the argillaceous metasedimentary rocks of the Inda Ad Series were unsuccessful. Both determinations shown in table 8 give ages younger than those given by crosscutting granites, and obviously the metasedimentary rocks have lost argon.

The Ra's Burūm granite of E.A.P. is unaffected by the movements that deformed metasedimentary rocks of Wādi al Ghabar, movements which can probably be correlated with the epimetamorphism of the older basement assemblage. Thus the crystalline basement rocks and the metasedimentary and older volcanic rocks of E.A.P. are also Cambrian or older.

In Aden Protectorate an earlier intrusive phase appears to be represented by the Wãdi al Ghabar and Wādi al Jif'iyah (Bayḩān) granites, dated at 560 and $550 \mathrm{~m} . \mathrm{y}$. , that is, of Middle Cambrian age. These are also posttectonic granites and as such set a younger limit to the epimetamorphism. An even later intrusive episode may be represented by determinations OGS.61.39 and OGS.63.11; these ages are Ordovician.

Three determinations on micas from basement rocks from Somalia and Aden Protectorate give ages ranging from 505 to $620 \mathrm{~m} . \mathrm{y}$. From the geochronological point of view it can be postulated that two types of mica are present in the metamorphosed basement rocks; those formed during the earlier katametamorphism, and those formed during the subsequent epimetamorphism.
However, as it is known that micas, and particularly biotites, lose argon fairly readily when metamorphosed, the ages as determined on the earlier micas can be expected to have been affected by the epimetamorphism. Their apparent ages are likely to be significantly lower than their true age - that is, the time of the epimetamorphism. The best estimate of the time of the katametamorphism is given by the greatest apparent age, which is about $600 \mathrm{~m} . \mathrm{y}$., in both Somalia and Aden Protectorate. The katametamorphism is thus older than 600 m.y.

Age determinations on the later micas ideally give the age of the epimetamorphism, which on the basis of the determinations made on the posttectonic granites, must be older than $515 \mathrm{~m} . \mathrm{y}$. and is probably older than $560 \mathrm{~m} . \mathrm{y}$.

Unfortunately this simple pattern can be complicated by natural argon leakage. Such argon loss does not normally appear to exceed about 10 percent, but even this would result in an apparent age some 50 m.y. too young. This may explain the apparently anomalous results of 505 m.y. given by the biotite from the Wādi Raybān mica schist, OGS.62.53.

Definite conclusions are not justified on the basis of the few age determinations so far made from the basement rocks of these areas, but as already suggested, the katametamorphism is almost certainly older than 600 m.y., whereas the epimetamorphism probably occurred between 560 m.y. and 600 m.y.

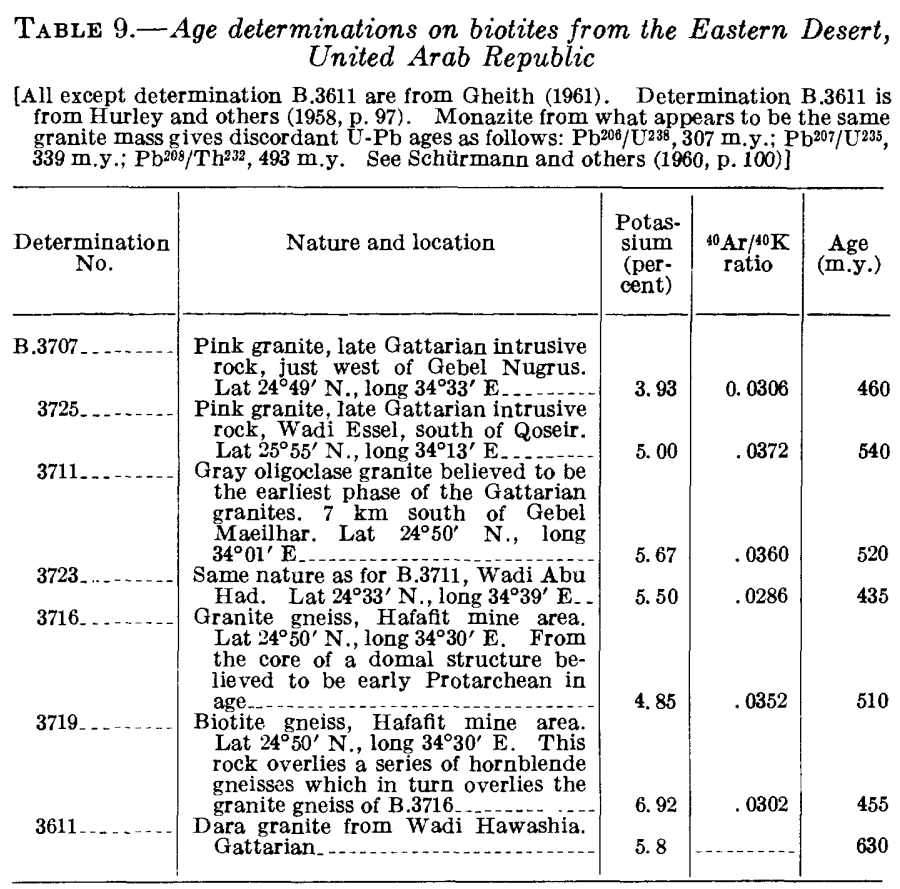


TABLE 10.-Age determinations on micas from Arabia [Sample numbers and locations given by Aldrich and others (1959, table 11, fig. 9).
Determinations also shown by Brown and Jackson (1960, fig. 1)]

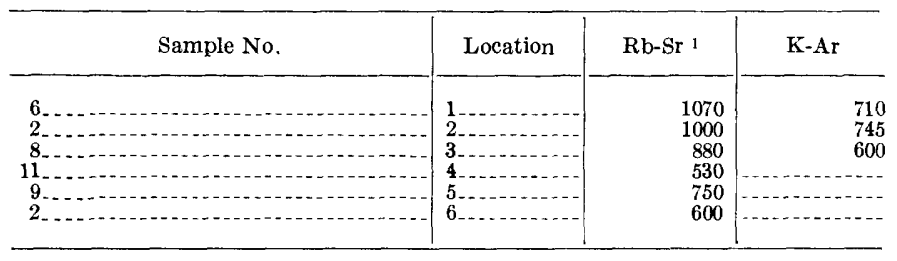

1 These are the ages obtained if a half life of $5.0 \times 10^{10} \mathrm{yr}$. is assumed for the decay of ${ }^{\mathrm{7}} \mathrm{Rb}$. To obtain the age on the basis of a half life of $4.7 \times 10^{10} \mathrm{yr}$, multiply by 0.94 .

Regarding comparison with other regions, age determinations from Egypt and other parts of the Arabian shield are given in tables 9 and 10. As described by Brown and Jackson (1960) the main mass of the Arabian shield in western Saudi Arabia appears to have much in common with Aden Protectorate and Somalia. Brown and Jackson recognized at least two major gneissic belts which intersect at right angles beneath the Sahl Rakbah. According to these authors, one belt, which extends northeastward from the Red Sea rift, has features of injection and migmatization and is flanked by a retrogressively metamorphosed group of mafic igneous rocks, slate, and quartzite, which they considered to be near the base of the Arabian geologic column. The other belt extends northeastward and has the characteristics of orthogneiss.

Determinations on micas from synkinematic granodiorites and related rocks give $\mathrm{Rb}-\mathrm{Sr}$ ages of about 1,000 m.y., whereas determinations on micas from somewhat younger batholiths and stocks of calc-alkalic granites and quartz diorites, which display both concordant and discordant features, give $\mathrm{Rb}-\mathrm{Sr}$ ages of 750 and $880 \mathrm{~m} . \mathrm{y}$. Still younger ages of 600 and $530 \mathrm{~m} . \mathrm{y}$. were also reported, the former on a mica from a "younger red intrusive" rock and the latter on a mica from an unmetamorphosed granite ring dike east of Aț Țā'if. If these last two ages are recalculated using the $R^{87}$ half life of $4.7 \times 10^{10} \mathrm{yr}$ (the value preferred by the writer), one gets ages of 565 and 500 m.y.

Probably the most important feature of these determinations, and one which was not mentioned by Brown and Jackson (1960), is that where both $\mathrm{Rb}$-Sr and $\mathrm{K}-\mathrm{Ar}$ ages have been determined the results are discordant (see table 10). Such discordance is generally accepted as being indicative of a metamorphism after initial crystallization. This later metamorphism probably is approximately the same age as the youngest $\mathrm{K}-\mathrm{Ar}$ apparent age, which is $600 \mathrm{~m} . \mathrm{y}$., particularly as there occurs in the same area the unmetamorphosed granite ring dike east of $A t T^{-}$'if which gives an age about $500 \mathrm{~m}$.y. (depending on the decay constant used in the age calculation). It thus appears that the crystalline gneisses and granitic rocks in regions stretching southwestward from Jiddah on the coast toward the border of Saudi Arabia and Yemen were subjected to two metamorphic episodes: the first, at about 1,000 m.y., was followed by the intrusion of granites which in turn were followed by a second and probably milder metamorphism between 600 and $500 \mathrm{~m} . \mathrm{y}$. By analogy with results from the Aden Protectorate, where posttectonic granite has been dated at $560 \mathrm{~m} . \mathrm{y}$., it may be suspected that the later metamorphism occurred in earliest Cambrian or latest Precambrian times.

Although Brown and Jackson made no reference to features in the basement gneisses and granites which could be indicative of polymetamorphism, the fact that the various low-grade metasedimentary and metavolcanic rocks, such as the Fatima Formation, have been subjected to mild mainly dynamic metamorphism and rest disconformably on basement gneisses and schists, implies more than one diastrophism; it is unlikely that the basement rocks, on which the low-grade metamorphic formations rest, would be unaffected by the later diastrophism. In fact, the age determinations indicate that these rocks were affected.

Age determinations from Egypt and the northern Sudan are given in table 9 . The ages are quite reminiscent of the dates determined from Somalia and Aden Protectorate. It is difficult to correlate these ages with the geologic succession proposed by Hume and Schürmann; the Gattarian granites give apparent ages ranging from 630 to $460 \mathrm{~m} . \mathrm{y}$. whereas gneisses from what were considered to be the oldest of the crystalline basement rocks give Paleozoic ages well within the apparent age span of the Gattarian granites.

\section{SELECTED REFERENCES FOR APPENDIX}

Aldrich, H. T., Wetherill, G. W., Bass, M. N., Compston, W., Davis, G. L., and Tilton, G. R., 1959, Mineral age measurements, in Annual report of the Director, Department of Terrestrial Magnetism: Carnegie Inst. Washington Year Book 58.

Beydoun, Z. R., 1960, Synopsis of the geology of East Aden Protectorate: Internat. Geol. Cong., 21st, Copenhagen 1960, Rept., pt. 21, p. 131-149.

Brown, G. F., and Jackson, R. O., 1960, The Arabian shield: Internat. Geol. Cong., 21st, Copenhagen 1960, Rept., pt. 9, p. 69-77.

Daniels, J. L., Skiba, W. J., and Sutton, J., 1963, The deformation of some banded gabbros in the northern Somalia foldbelt [abs.]: Geol. Soc. London Circ. 107.

Gheith, M. A., 1961, Age of basement rocks in eastern United Arab Republic and northern Sudan: New York Acad. Sci. Annals, v. 91, p. 530-534. 
Greenwood, J. E. G. W., 1961, The Inda Ad series of the former Somaliland Protectorate: London, Overseas Geology and Mineral Resources Bull., v. 8, no. 3, p. 288-296.

Hume, W. F., 1934, 1935, Geology of Egypt: Cairo, United Arab Republic, Survey of Egypt Govt. Press, v. 2, pt. 1, 300 p., and pt. 2, $494 \mathrm{p}$.

Hurley, P. M., and others, 1958, Variations in the isotope abundances of strontium, calcium, and argon and related topics: U.S. Atomic Energy Comm., [Pub.] NYO-3938, $228 \mathrm{p}$.

Schürmann, H. M. E., 1953, The Precambrian of the Gulf of
Suez area: Internat. Geol. Cong., 19th, Algiers 1952, Comptes rendus, pt. 1, p. 115-135.

1957, The Precambrian of Egypt, east of the River Nile: Geologie en Mijnbouw, new ser., v. 19, no. 5, p 165-171.

Schürmann, H. M. E., Aten, A. H. W., Boerboom, A. J. H., Bot, A. C. W. C., Couwenberg, G., Dance, D. F., Hurley, P. M., Ledent, D., Stauffer, H., Steensma, J. J. S., and Suringa, R., 1960, Fourth preliminary note on age determinations of magmatic rocks by means of radioactivity: Geologie en Mijnbouw, new ser., v. 39, p. 93-104.

U. S. GOVERNMENT PRINTING OFFICE : 1967 O - 221-671 